\title{
Engaging Alkenyl Halides with Alkylsilicates via Photoredox Dual Catalysis
}

\author{
Niki R. Patel, Christopher B. Kelly, Matthieu Jouffroy, and Gary A. Molander* \\ Roy and Diana Vagelos Laboratories, Department of Chemistry, University of Pennsylvania, \\ Philadelphia, Pennsylvania 19104-6323
}

*To whom correspondence should be addressed. E-mail: gmolandr@sas.upenn.edu

\section{Supporting Information}

\section{Key to Abbreviated Terms $\quad$ S2}

General Considerations

S2

Comments regarding origins of starting materials, purification of solvents, photoreactors, and spectroscopic techniques.

\section{Photochemical Reactor Design}

Details regarding the design of LED-based photoreactors, instructions for their preparation, and photographs.

\section{Synthesis of Silicates}

Procedures for the preparation of silicates for dual catalytic cross-coupling and spectral characterization information.

\section{Synthesis of Alkenyl Halides}

Procedures for the preparation of alkenyl halides for dual catalytic cross-coupling and spectral characterization information.

\section{Synthesis of $\mathrm{Ru}(\mathrm{bpy})_{3}\left(\mathrm{PF}_{6}\right)_{2}$}

Procedure for photocatalyst synthesis.

General Procedures for Alkene Cross-Coupling

General procedure for synthesis, isolation procedures, and

spectral characterization information for cross-coupled alkenes.

Modified Procedure for Large Scale Cross-Coupling

General procedure for scale up of the described cross-coupling.

Reaction Monitoring and Control Studies for Alkene Cross-Coupling S32

${ }^{1}$ H NMR Spectra of Synthesized Compounds $\quad$ S34

${ }^{13} \mathrm{C}$ NMR Spectra of Synthesized Compounds $\quad$ S83 


\section{Key to Abbreviated Terms:}

bpy: 2,2'-bipyridyl

CFL: Compact fluorescent light

dtbbpy: 4,4'-di-tert-butyl-2,2'-dipyridyl
LED: Light-emitting diode

TMG: 1,1,3,3-Tetramethylguanidine

\section{General Considerations:}

\section{General:}

All chemical transformations requiring inert atmospheric conditions or vacuum distillation utilized Schlenk line techniques with a 4- or 5-port dual-bank manifold. Argon or nitrogen was used to provide such an atmosphere. NMR Spectra $\left({ }^{1} \mathrm{H},{ }^{13} \mathrm{C}\right)$ were performed at $298 \mathrm{~K}$. ${ }^{1} \mathrm{H}$ NMR spectra obtained in $\mathrm{CDCl}_{3}$ were referenced to residual non-deuterated chloroform $(\delta 7.26)$ in the deuterated solvent. Spectra obtained in DMSO- $d_{6}$ were referenced to residual DMSO- $d_{5}(\delta 2.50)$ in the deuterated solvent. ${ }^{13} \mathrm{C}$ NMR spectra obtained in $\mathrm{CDCl}_{3}$ were referenced to chloroform $(\delta$ 77.3). ${ }^{13} \mathrm{C}$ NMR spectra obtained in DMSO- $d_{6}$ were referenced to DMSO $(\delta 39.5)$. Reactions were monitored by GC/MS, ${ }^{1} \mathrm{H}$ NMR, and/or by TLC on silica gel plates ( $60 \AA$ porosity, $250 \mu \mathrm{m}$ thickness). TLC analysis was performed using hexanes/EtOAc as the eluant and visualized using permanganate stain, Seebach's stain, ${ }^{1}$ ninhydrin stain, and/or UV light. Silica plugs utilized flash

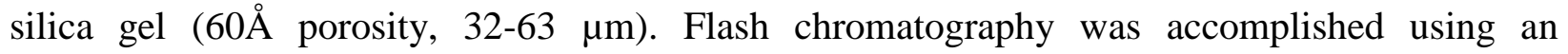
automated system (visualizing at $254 \mathrm{~nm}$, monitoring at $280 \mathrm{~nm}$ ) with silica cartridges $(60 \AA$ porosity, 20-40 $\mu \mathrm{m}$ ). Solvents were purified either by distillation over sodium or $\mathrm{CaH}_{2}$ or by use of drying cartridges through a solvent delivery system. Melting points $\left({ }^{\circ} \mathrm{C}\right)$ are uncorrected.

\section{Chemicals:}

Deuterated NMR solvents were either used as purchased (DMSO- $d_{6}$ ) or were stored over $4 \AA$ molecular sieves and $\mathrm{K}_{2} \mathrm{CO}_{3}\left(\mathrm{CDCl}_{3}\right) . \mathrm{Na}_{2} \mathrm{SO}_{4}, \mathrm{MgSO}_{4}, \mathrm{MeOH}, \mathrm{CH}_{2} \mathrm{Cl}_{2}, \mathrm{CHCl}_{3}, \mathrm{MeCN}$, pentane, $\mathrm{Et}_{2} \mathrm{O}$, and pyridine, were used as purchased. $\mathrm{Et}_{3} \mathrm{~N}$ and $i-\mathrm{Pr}_{2} \mathrm{NH}$, were purchased from commercial suppliers and distilled from $\mathrm{CaH}_{2}$ prior to use. THF was purchased from commercial suppliers and dried via a solvent delivery system. Catechol was purchased and recrystallized from refluxing hexanes or heptanes. DMF (99.8\%, extra dry) was stored over $4 \AA$ molecular sieves. $\mathrm{NiCl}_{2} \bullet \mathrm{dme}$ (min. 97\%) and $\mathrm{RuCl}_{3} \cdot 3 \mathrm{H}_{2} \mathrm{O}$ were purchased commercially. Alkenyl halides were either purchased from commercial suppliers or prepared in-house. In the case of the latter, syntheses of these halides are provided. The alkenyl halides trans-1-iodo-1-octene (2a), $\beta$ bromostyrene (2b), 2-bromoindene (2e), ethyl cis-3-bromoacrylate (2f), bromomethylenecyclohexane (2h), 1-bromo-2-methyl-propene (2i), and 1-chloro-1-cyclopentene (2l) were purchased from commercial suppliers and used without further purification. $\mathrm{Ru}(\mathrm{bpy})_{3}\left(\mathrm{PF}_{6}\right)_{2}$ was prepared in-house by the procedure outlined here. Silicates were prepared according to the representative procedure outlined here from their corresponding

\footnotetext{
${ }^{1}$ Seebach, D.; Imwinkelried, R; Stucky, G. Helv. Chim. Acta. 1987, 70, 448.
} 
alkyltrimethoxysilanes. Characterization data for new silicates is provided. Information (preparation protocols, characterization etc.) for silicates $\mathbf{1 c}, \mathbf{1 d}, \mathbf{1 e}, \mathbf{1 h}, \mathbf{1 i}, \mathbf{1}$, and $\mathbf{1 m}$ can be found in our previous report. ${ }^{2}$

\section{Photochemistry:}

Irradiation of reaction vessels was accomplished either using standard 26 W CFLs or LEDs (blue or white). The choice of light source did not seem to have any effect on reaction success. In most cases either CFL or blue LEDs were employed for irradiation. LEDs were configured as outlined in the Photochemical Reactor Design section. A fan was employed to ensure reactions remained at or near room temperature when using either CFLs or LEDs.

\section{Information for LED-based Photoreactor Components:}

- Blue LEDs: 39.4 inch strips, $470 \mathrm{~nm}$ blue light, $32918 \mathrm{mcd} \mathrm{ft}^{-1}$

- Natural White LEDs: 39.4 inch strips, 380-700 nm, CCT rating: 4000K

- Power Supply: 12V DC CPS series Power Supply - 15 Watt

- Connectors (links power supply to LEDs): LC2 Locking Male Connector CPS Adapter Cable

- Clip Fan: 2-Speed Clip Fan, 6-Inch

- Pyrex crystallizing dishes (125 X $65 \mathrm{~mm})$

- Aluminum foil

- Duct tape

\footnotetext{
${ }^{2}$ Jouffroy, M.; Primer, D.; Molander, G. A. J. Am. Chem. Soc., 2015, ASAP DOI: 10.1021/jacs.5b10963
} 


\section{Photochemical Reactor Design (LEDs only)}

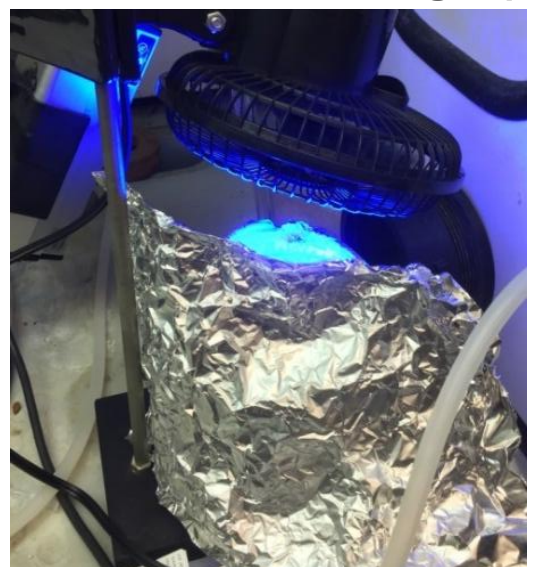

\section{Protocol for reactor setup}

Remove the protective layer on the sticky side of the LED strip and carefully wrap the LED strips on the inside of a clean Pyrex dish. ${ }^{3}$ Four bands of LEDs can fit into a 125 X $65 \mathrm{~mm}$ Pyrex crystallizing dish. ${ }^{4}$ Once the LEDs are securely wrapped, place a layer of aluminium foil around the outside of the dish (including the

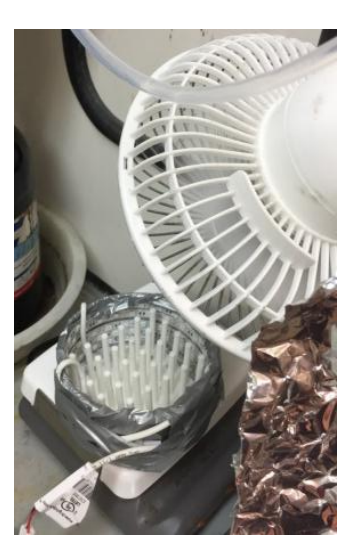
bottom). Tape the connector wires as well as the foil with duct tape to secure both in place. For vial-scale reactions, cut a sample vial rack using a saw and place it inside. For larger

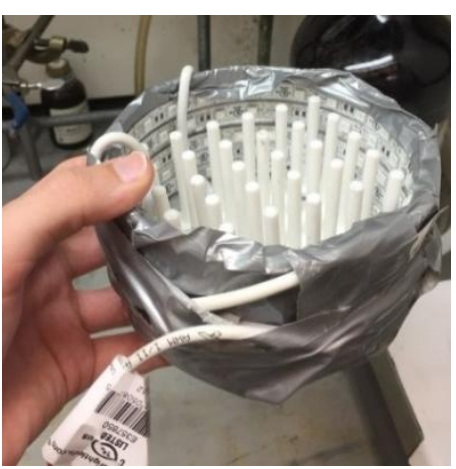
vessels (e.g., round bottom flasks), simply lower the flask into the irradiation bay. ${ }^{5}$ Place the reactor on top of a stirring place. Position a fan about 6-12 inches above the reactor for cooling and set it to its maximum setting. Turn on the lights and fan. Allow 15 min to pass for temperature equilibration. Temperature should be monitored in real time using a temperature probe to determine the ambient temperature within the reactor. Place a double layer of aluminum foil in front of the reactor to reflect light back into the reactor. CAUTION: Given the brightness of the reactor, it is recommended that impact-resistant sunglasses are used when working with the reactor for eye protection.

\footnotetext{
${ }^{3}$ Starting from the bottom upward affords the easiest approach.

${ }^{4}$ If smaller lengths of LED strips are used, they can be linked together. Most LED strips are able to be cut (at specified locations) and powered by either end. The appropriate connector is required (male or female) for each end. ${ }^{5}$ This design can accommodate up to a $250 \mathrm{~mL}$ round bottom flask. However, if desired, a larger reactor can be assembled by using larger recrystallization dish and additional LEDs.
} 


\section{Representative Synthesis of Silicates \\ Preparation of triethylammonium bis(catecholato)cyclopentylsilicate (1b)}

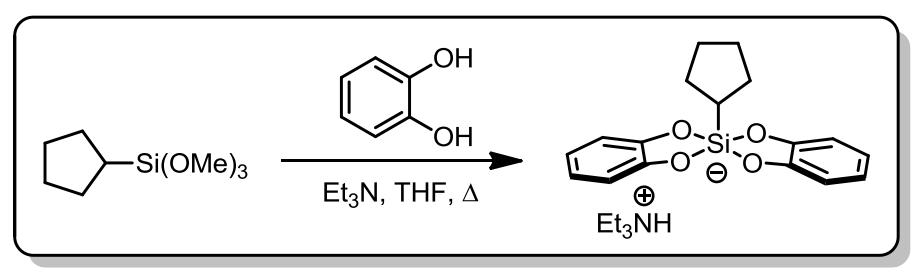

To an oven-dried $100 \mathrm{~mL}$ round bottom flask equipped with a stir bar, reflux condenser, and gas inlet adapter was added catechol ${ }^{6}$ ( $3.99 \mathrm{~g}, 0.0362 \mathrm{~mol}, 1.95$ equiv) followed by anhyd THF (35 $\mathrm{mL})$ and anhyd $\mathrm{Et}_{3} \mathrm{~N}(2.26 \mathrm{~g}, 3.1 \mathrm{~mL}, 0.223 \mathrm{~mol}, 1.2$ equiv). The mixture was placed under an argon atmosphere and was allowed to stir at $\mathrm{rt}$ for $5 \mathrm{~min}$. The solution became a pale reddish brown. After this time, the cyclopentyltrimethoxysilane ( $3.54 \mathrm{~g}, 0.0186 \mathrm{~mol}, 1$ equiv) dissolved in a minimal amount of THF $(5 \mathrm{~mL})$ was added all at once. The solution immediately lightened to a golden yellow. The solution was then heated to reflux in an oil bath and allowed to stir at this temperature overnight. ${ }^{7}$ Once the reaction was judged to be complete by crude ${ }^{1} \mathrm{H}$ NMR analysis, ${ }^{8}$ the solvent was removed in vacuo by rotary evaporation. The crude solid was dissolved in $\mathrm{CH}_{2} \mathrm{Cl}_{2}(\sim 60 \mathrm{~mL})$, and a minimum amount of pentane $(\sim 10 \mathrm{~mL})$ was added as an anti-solvent, resulting in precipitation of a fine white powder. The powder was collected via filtration through a medium porosity fritted funnel. The powder was washed with a minimal amount of $\mathrm{Et}_{2} \mathrm{O}(\sim 10 \mathrm{~mL})$ followed by a copious amount of pentane $(\sim 125 \mathrm{~mL})$. The solid was collected and dried further in vacuo to give the pure silicate $(5.23 \mathrm{~g}, 68 \%)$ as a powdery offwhite solid $\left(\mathrm{mp}=201{ }^{\circ} \mathrm{C}\right)$.

${ }^{1}$ H NMR (DMSO- $\left.d_{6}, 500 \mathrm{MHz}\right) \delta 0.81-0.90(\mathrm{~m}, 1 \mathrm{H}), 1.16(\mathrm{t}, J=7.2 \mathrm{~Hz}, 9 \mathrm{H}), 1.20-1.26(\mathrm{~m}$, $2 \mathrm{H}), 1.26-1.40(\mathrm{~m}, 4 \mathrm{H}), 1.40-1.50(\mathrm{~m}, 2 \mathrm{H}), 3.08(\mathrm{q}, J=7.3 \mathrm{~Hz}, 6 \mathrm{H}), 6.39-6.44(\mathrm{~m}, 4 \mathrm{H}), 6.48$ - $6.52(\mathrm{~m}, 4 \mathrm{H}), 8.82(\mathrm{br} \mathrm{s}, 1 \mathrm{H}) .{ }^{13} \mathrm{C}$ NMR (DMSO- $\left.d_{6}, 125 \mathrm{MHz}\right) \delta 8.6\left(\mathrm{CH}_{3}\right), 25.9\left(\mathrm{CH}_{2}\right), 28.5$ $\left(\mathrm{CH}_{2}\right), 29.8(\mathrm{CH}), 45.8\left(\mathrm{CH}_{2}\right), 109.2(\mathrm{C}), 116.9(\mathrm{CH}), 150.9(\mathrm{CH})$. FT-IR $\left(\mathrm{cm}^{-1}\right.$, neat, ATR 3040 (w, br), 2950 (w, b), 1486 (vs), 1243 (vs), 1015 (w), 818 (vs), 732 (vs), 522 (vs). HRMS (ES-) calcd for $\left.\mathrm{C}_{23} \mathrm{H}_{33} \mathrm{NO}_{4} \mathrm{Si}[\mathrm{M}]\right]^{-}: 313.0896$, found: 313.0902 .

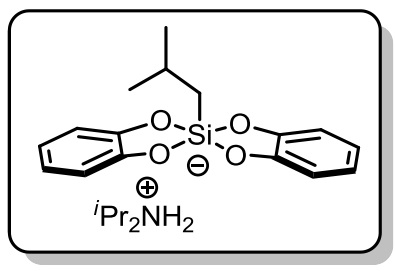

Diisopropylammonium Bis(catecholato)isobutylsilicate, $1 \mathrm{~g}(4.86 \mathrm{~g}$, $86 \%$ ) was prepared according to the general procedure for silicate synthesis from isobutyltrimethoxysilane $(2.50 \mathrm{~g}, 0.014 \mathrm{~mol})$ with the following modification: $i-\mathrm{Pr}_{2} \mathrm{NH}(1.70 \mathrm{~g}, 2.35 \mathrm{~mL}, 0.0168 \mathrm{~mol}, 1.2$ equiv) was used in place of $\mathrm{Et}_{3} \mathrm{~N}$. The desired silicate $1 \mathbf{g}$ was isolated as a powdery white solid $\left(\mathrm{mp}=216{ }^{\circ} \mathrm{C}\right)$.

${ }^{1} \mathrm{H}$ NMR (DMSO- $\left.d_{6}, 500 \mathrm{MHz}\right) \delta 0.50(\mathrm{~d}, J=6.8 \mathrm{~Hz}, 2 \mathrm{H}), 0.75(\mathrm{~d}, J=6.4 \mathrm{~Hz}, 6 \mathrm{H}), 1.20(\mathrm{~d}, J=$ $6.6 \mathrm{~Hz}, 12 \mathrm{H}), 1.68$ (sept, $J=6.6 \mathrm{~Hz}, 1 \mathrm{H}), 3.35(\mathrm{dt}, J=12.9,6.4 \mathrm{~Hz}, 2 \mathrm{H}), 6.39-6.45(\mathrm{~m}, 4 \mathrm{H})$,

\footnotetext{
${ }^{6}$ Recrystallized from hexane or heptane prior to use.

${ }^{7}$ Depending on the nature of the silicate and its solubility in THF, precipitation of the product would occur.

${ }^{8}$ For DIPA silicates, it is advisable to use deuterated acetone as the NMR solvent, as they have poor solubility in most other deuterated solvents.
} 
6.47 - 6.55 (m, 4H), 8.02 (br s, 2H). ${ }^{13} \mathrm{C}$ NMR (DMSO-d $\left.d_{6}, 125 \mathrm{MHz}\right) \delta 18.8\left(\mathrm{CH}_{3}\right), 24.4(\mathrm{CH})$, $26.3\left(\mathrm{CH}_{3}\right), 29.4\left(\mathrm{CH}_{2}\right), 46.4(\mathrm{CH}), 109.4(\mathrm{C}), 117.0(\mathrm{CH}), 150.6(\mathrm{CH})$. FT-IR $\left(\mathrm{cm}^{-1}\right.$, neat, ATR) 3047 (w, br), 2948 (w), 1484 (vs), 1238 (vs), 1014 (w), 812 (w), 734 (vs), 498 (m). HRMS (ES-) calcd for $\mathrm{C}_{16} \mathrm{H}_{17} \mathrm{O}_{4} \mathrm{Si}[\mathrm{M}]$ : 301.0896 , found: 301.0899 .

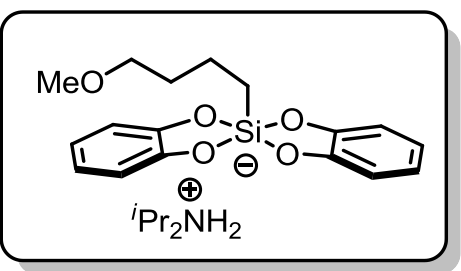

Diisopropylammonium Bis(catecholato)(3-

methoxypropyl)silicate, $\mathbf{1 j}$ (5.39 g, 86\%) was prepared according to the general procedure for silicate synthesis from (3-

methoxypropyl)trimethoxysilane $(2.91 \mathrm{~g}, 0.015 \mathrm{~mol})$ with the following modification: $i$ - $\operatorname{Pr}_{2} \mathrm{NH}(1.82 \mathrm{~g}, 2.52 \mathrm{~mL}, 0.018 \mathrm{~mol}, 1.2$ equiv) was used in place of $\mathrm{Et}_{3} \mathrm{~N}$. The desired silicate $\mathbf{1 j}$ was isolated as a powdery off-white solid $\left(\mathrm{mp}=208^{\circ} \mathrm{C}\right)$.

${ }^{1}$ H NMR (DMSO- $\left.d_{6}, 500 \mathrm{MHz}\right) \delta 0.39-0.51(\mathrm{~m}, 2 \mathrm{H}), 1.19(\mathrm{~d}, J=6.4 \mathrm{~Hz}, 12 \mathrm{H}), 1.34-1.49$ $(\mathrm{m}, 2 \mathrm{H}), 3.08(\mathrm{~s}, 3 \mathrm{H}), 3.10(\mathrm{t}, J=6.8 \mathrm{~Hz}, 2 \mathrm{H}), 3.35$ (sept, $J=6.4 \mathrm{~Hz}, 2 \mathrm{H}), 6.41-6.48(\mathrm{~m}, 4 \mathrm{H})$, 6.49 - 6.59 (m, 4H), 8.03 (br s, 2H). ${ }^{13} \mathrm{C}$ NMR (DMSO- $\left.d_{6}, 125 \mathrm{MHz}\right) \delta 13.9\left(\mathrm{CH}_{2}\right), 18.8(\mathrm{CH})$, $24.4\left(\mathrm{CH}_{2}\right), 46.4(\mathrm{CH}), 57.5\left(\mathrm{CH}_{3}\right), 75.1\left(\mathrm{CH}_{2}\right), 109.5(\mathrm{C}), 117.1(\mathrm{CH}), 150.5(\mathrm{CH})$. FT-IR $\left(\mathrm{cm}^{-1}\right.$, neat, ATR) 3045 (w, br), 2872 (w, br), 1582 (w), 1484 (s), 1237 (s), 810 (s), 734 (s). HRMS (ES-) calcd for $\mathrm{C}_{22} \mathrm{H}_{33} \mathrm{NO}_{5} \mathrm{Si}[\mathrm{M}]^{-}: 317.0845$, found: 317.0849 .

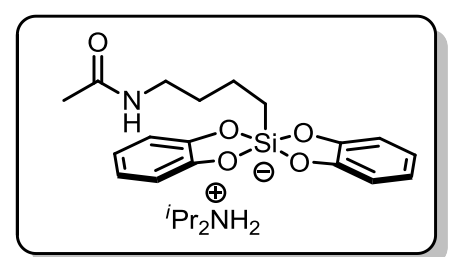

${ }^{1} \mathrm{H}$ NMR (DMSO- $\left.d_{6}, 500 \mathrm{MHz}\right) \delta 0.36-0.51(\mathrm{~m}, 2 \mathrm{H}), 1.19(\mathrm{~d}, J=6.6 \mathrm{~Hz}, 12 \mathrm{H}), 1.23-1.34(\mathrm{~m}$, 2H), $1.71(\mathrm{~s}, 3 \mathrm{H}), 2.80(\mathrm{q}, J=6.8 \mathrm{~Hz}, 2 \mathrm{H}), 3.35$ (sept, $J=6.6 \mathrm{~Hz}, 2 \mathrm{H}), 6.40-6.46(\mathrm{~m}, 4 \mathrm{H}), 6.48$ - 6.55 (m, 4H), 7.62 (br s, 1H), 8.01 (br s, 2H). ${ }^{13} \mathrm{C}$ NMR (DMSO- $\left.d_{6}, 125 \mathrm{MHz}\right) \delta 15.8\left(\mathrm{CH}_{2}\right)$, $18.8\left(\mathrm{CH}_{3}\right), 22.6\left(\mathrm{CH}_{3}\right), 24.8\left(\mathrm{CH}_{2}\right), 42.0\left(\mathrm{CH}_{2}\right), 46.3(\mathrm{CH}), 109.5(\mathrm{C}), 117.0(\mathrm{CH}), 150.5(\mathrm{CH})$, 168.5 (C). FT-IR (cm ${ }^{-1}$, neat, ATR) 3339 (w, br), 3092 (vw, br.), 2880 (vw, br.), 1487 (s), 1242 (s), 1015 (w), 818 (vs), 736 (vs), 595 (m). HRMS (ES-) calcd for $\mathrm{C}_{23} \mathrm{H}_{34} \mathrm{~N}_{2} \mathrm{O}_{5} \mathrm{Si}[\mathrm{M}]{ }^{-}: 344.0954$, found: 344.0966 .

\section{Preparation of Triethylammonium Bis(catecholato)allylsilicate (1f)}

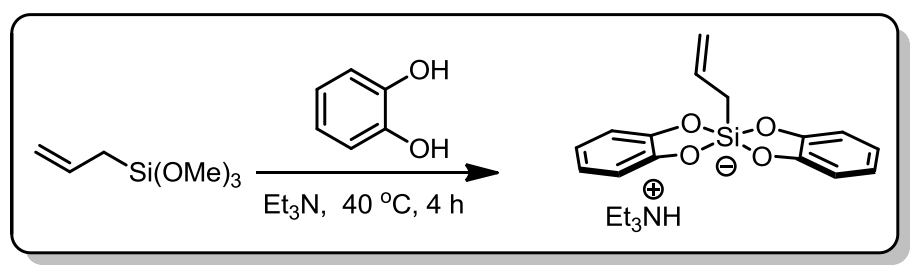

Allyl silicate $\mathbf{1 f}$ was prepared according to the procedure outlined by Hosomi. ${ }^{9}$ To a $25 \mathrm{~mL}$ round bottom flask equipped with a stir bar was added anhyd $\mathrm{Et}_{3} \mathrm{~N}(2.15 \mathrm{~g}, 2.96 \mathrm{~mL}, 0.0213 \mathrm{~mol}$,

\footnotetext{
${ }^{9}$ Hosomi, A.; Kohra, S.; Ogata, K.; Yanagi, T.; Tominaga, Y. J. Org. Chem., 1990, 55, 2415.
} 
4.25 equiv) and catechol ${ }^{10}(1.13 \mathrm{~g}, 0.01025 \mathrm{~mol}, 2.05$ equiv) followed by allyltrimethoxysilane $(0.811 \mathrm{~g}, 0.005 \mathrm{~mol}, 1$ equiv). The flask was sealed with a septum and placed under an argon atmosphere via an inlet needle. The solution was heated to $40{ }^{\circ} \mathrm{C}$ via an oil bath and stirred at this temp for $4 \mathrm{~h}$. Formation of a light pink precipitate was observed during the course of the reaction. After this time, the flask was cooled to rt, and the solid was filtered and washed with pentane $(\sim 100 \mathrm{~mL})$. The crude solid was dissolved in $\mathrm{CH}_{2} \mathrm{Cl}_{2}(\sim 40 \mathrm{~mL})$, and a minimum amount of pentane $(\sim 5 \mathrm{~mL})$ was added as an anti-solvent, resulting in precipitation of a fine light pink powder. The powder was collected via filtration through a medium porosity fritted funnel. The powder was with pentane $(\sim 100 \mathrm{~mL})$. The solid was collected and dried further in vacuo to give the pure silicate $(1.06 \mathrm{~g}, 55 \%)$ as a powdery pale pink solid $\left(\mathrm{mp}=128^{\circ} \mathrm{C}\right)$.

${ }^{1} \mathrm{H}$ NMR (DMSO- $\left.d_{6}, 500 \mathrm{MHz}\right) \delta 1.15(\mathrm{t}, J=7.3 \mathrm{~Hz}, 9 \mathrm{H}), 1.50(\mathrm{~d}, J=8.1 \mathrm{~Hz}, 2 \mathrm{H}), 3.08(\mathrm{q}, J=$ $7.2 \mathrm{~Hz}, 6 \mathrm{H}), 4.47$ (dt, $J=10.0,1.2 \mathrm{~Hz}, 1 \mathrm{H}), 4.58(\mathrm{dt}, J=17.1,1.1 \mathrm{~Hz}, 1 \mathrm{H}), 5.67$ ( tdd, $J=17.4$, $8.1,1.8 \mathrm{~Hz}, 1 \mathrm{H})$ ) $, 6.40-6.46(\mathrm{~m}, 4 \mathrm{H}), 6.49-6.55(\mathrm{~m}, 4 \mathrm{H}), 8.76(\mathrm{br} \mathrm{s}, 1 \mathrm{H}) .{ }^{13} \mathrm{C}$ NMR (DMSO$\left.d_{6}, 125 \mathrm{MHz}\right) \delta 8.6\left(\mathrm{CH}_{3}\right), 26.2\left(\mathrm{CH}_{2}\right), 45.8\left(\mathrm{CH}_{2}\right), 109.5(\mathrm{C}), 110.8(\mathrm{~s}, 1 \mathrm{C}), 117.1\left(\mathrm{CH}_{2}\right), 137.5$ (CH), 150.4 (C). FT-IR ( $\mathrm{cm}^{-1}$, neat, ATR) 3065 (vw, br), 2952 (vw, b), 1486 (s), 1245 (s), 1013 (w), 855 (w), 827 (vs), 732 (s), $664(\mathrm{~m})$. HRMS (ES-) calcd for $\mathrm{C}_{21} \mathrm{H}_{29} \mathrm{NO}_{4} \mathrm{Si}[\mathrm{M}]{ }^{-2}$ : 285.0583, found: 285.0587 .

\footnotetext{
${ }^{10}$ Recrystallized from hexane or heptane prior to use
} 


\section{Synthesis of Alkenyl Halides \\ Preparation of $(E)$-1-(2-bromovinyl)-4-methoxybenzene $^{11}$ (2c)}

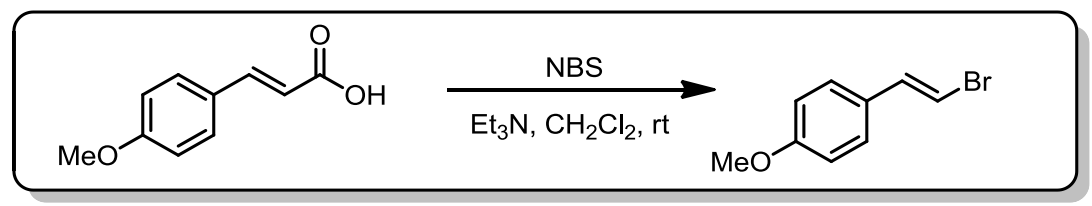

This procedure is a modification of the procedure outlined by Alexakis. ${ }^{11}$ To a $100 \mathrm{~mL}$ round bottom flask equipped with a stir bar was added $(E)$-3-(4-methoxyphenyl)acrylic acid (1.78 g, 0.010 mol, 1 equiv) and $\mathrm{CH}_{2} \mathrm{Cl}_{2}(35 \mathrm{~mL})$. $\mathrm{Et}_{3} \mathrm{~N}(0.051 \mathrm{~g}, 0.0005 \mathrm{~mol}, 0.05$ equiv) was added to the suspension and was stirred for $5 \mathrm{~min}$ at rt. At this time NBS $(2.14 \mathrm{~g}, 0.012 \mathrm{~mol}, 1.2$ equiv) was added all at once, and the reaction was stirred at rt. After $5 \mathrm{~min}$, the suspension began to clear and, after $20 \mathrm{~min}$, it became a clear, pale yellow solution. ${ }^{12} \mathrm{CO}_{2}$ evolution was observed during this time. The now clear solution was allowed to stir overnight. After this time, the solvent was removed in vacuo by rotary evaporation, resulting in a crude tan solid. The solid was transferred to a medium porosity fritted funnel and washed with pentane $(\sim 200 \mathrm{~mL})$. The pentane was then removed in vacuo by rotary evaporation, resulting in a semi-solid, which was taken up in a minimum amount of pentane $(\sim 5 \mathrm{~mL})$. Filtration through a short pad of silica followed by eluting with 95:5 hexane/EtOAc afforded a clear, pale yellow solution. Removal of the solvent in vacuo gave the desired alkenyl bromide, $2 \mathbf{c}$, as an off-white, powdery solid $(1.52 \mathrm{~g}, 71 \%) . \mathrm{mp}=$ $51{ }^{\circ} \mathrm{C}$

${ }^{1} \mathrm{H}$ NMR $\left(\mathrm{CDCl}_{3}, 500 \mathrm{MHz}\right) \delta 3.81(\mathrm{~s}, 3 \mathrm{H}), 6.61(\mathrm{~d}, J=13.7 \mathrm{~Hz}, 1 \mathrm{H}), 6.85(\mathrm{~d}, J=8.8 \mathrm{~Hz}, 2 \mathrm{H})$, $7.04(\mathrm{~d}, J=13.7 \mathrm{~Hz}, 1 \mathrm{H}), 7.24(\mathrm{~d}, J=8.2 \mathrm{~Hz}, 2 \mathrm{H}) .{ }^{13} \mathrm{C} \mathrm{NMR}\left(\mathrm{CDCl}_{3}, 125 \mathrm{MHz}\right) \delta 55.5\left(\mathrm{CH}_{3}\right)$, 104.2 (CH), $114.4(\mathrm{CH}), 127.5(\mathrm{CH}), 129.0(\mathrm{C}), 136.8(\mathrm{CH}), 159.9(\mathrm{C})$. GC-MS (EI) $214\left([\mathrm{M}]^{+}\right.$, $\left.{ }^{81} \mathrm{Br} 99 \%\right), 212\left([\mathrm{M}]+{ }^{+}{ }^{7} \mathrm{Br} 100 \%\right), 199\left({ }^{81} \mathrm{Br} 44 \%\right), 197\left({ }^{79} \mathrm{Br} 44 \%\right), 171\left({ }^{81} \mathrm{Br} 17 \%\right), 169\left({ }^{79} \mathrm{Br}\right.$ $18 \%), 133$ (31\%), 118 (21\%), 90 (39\%), 99 (9\%), 63 (20\%), 51 (6\%).

\section{Preparation of (Z)-1-(2-bromovinyl)-4-chlorobenzene ${ }^{13}$ (2d)}

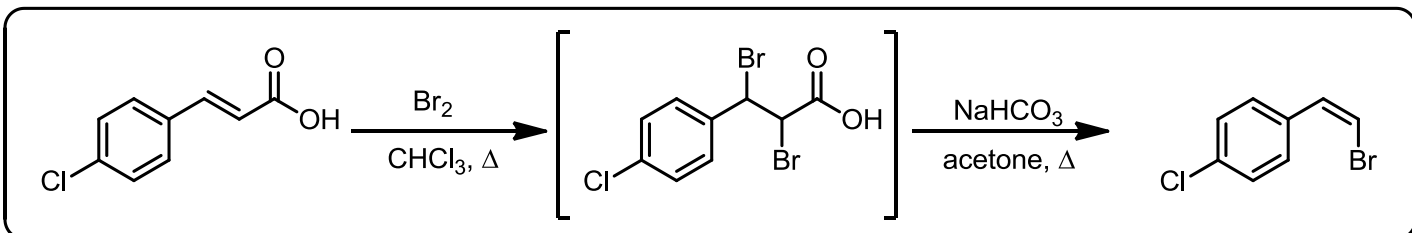

Stage One: Bromination

The following procedure is a modification of the procedure outlined by Stille. ${ }^{13}$ To a $250 \mathrm{~mL}$ round bottom flask equipped with a stir bar and reflux condenser was added (E)-3-(4chlorophenyl)acrylic acid $\left(9.13 \mathrm{~g}, 0.050 \mathrm{~mol}, 1\right.$ equiv) and $\mathrm{CHCl}_{3}(72 \mathrm{~mL})$. After stirring for 5

\footnotetext{
${ }^{11}$ Mueller, D.; Alexakis, A. Chem. Eur. J. 2013, 19, 15226.

${ }^{12}$ If this induction period does not occur an additional 0.1-0.2 equiv of $\mathrm{Et}_{3 \mathrm{~N}}$ should be added.

${ }^{13}$ Loar, M. K.; Stille, J. K. J. Am. Chem. Soc. 1981, 103, 4174.
} 
min, $\mathrm{Br}_{2}$ (8.31 g, $2.66 \mathrm{~mL}, 1.04$ equiv) was added dropwise to the flask. After complete addition of $\mathrm{Br}_{2}$, the solution was heated to reflux and allowed to stir overnight. The solution became clear, and then the formation of a precipitate was observed. After stirring overnight, the solution was cooled to $\mathrm{rt}$, and the solvent was removed in vacuo by rotary evaporation. The solid was transferred to a medium porosity fritted funnel and washed with a minimum amount of cold $\mathrm{Et}_{2} \mathrm{O}$ $(\sim 25 \mathrm{~mL})$ followed by a copious amount of pentane $(\sim 200 \mathrm{~mL})$. The solid was dried in vacuo, giving the crude dibromide as a white solid $(13.1 \mathrm{~g}, 77 \%)$, which was used directly in the next step.

\section{Stage Two: Elimination}

The crude dibromide $(12.5 \mathrm{~g}, 0.0365 \mathrm{~mol})$ from the previous step was transferred to a $250 \mathrm{~mL}$ round bottom flask equipped with a stir bar and reflux condenser. HPLC grade acetone (140 mL) followed by $\mathrm{NaHCO}_{3}(13.15 \mathrm{~g}, 0.124 \mathrm{~mol}, 3.4$ equiv) was added to the flask, and the solution was heated to reflux via an oil bath. The solution was stirred at reflux overnight. After this time, the solution was cooled to $\mathrm{rt}$, and the solvent was removed in vacuo by rotary evaporation. The resulting slurry was dissolved in a mixture of $\mathrm{Et}_{2} \mathrm{O}(\sim 100 \mathrm{~mL})$ and deionized $\mathrm{H}_{2} \mathrm{O}(\sim 100 \mathrm{~mL})$ and transferred to a separatory funnel. The layers were separated, and the aqueous layer was extracted with $\mathrm{Et}_{2} \mathrm{O}(2 \times \sim 125 \mathrm{~mL})$. The combined organic layers were washed with saturated aq $\mathrm{NaHCO}_{3}(\sim 100 \mathrm{~mL})$, deionized $\mathrm{H}_{2} \mathrm{O}(\sim 100 \mathrm{~mL})$, and brine $(\sim 150 \mathrm{~mL})$. The organic layer was dried $\left(\mathrm{Na}_{2} \mathrm{SO}_{4}\right)$, and the solvent was removed in vacuo by rotary evaporation. Filtration through a short pad of silica followed by eluting with pentane afforded a clear, pale yellow solution. Removal of the pentane in vacuo gave the desired alkenyl bromide, 2d, as a pale yellow oil (6.98 g, $88 \%$ ).

${ }^{1} \mathrm{H}$ NMR $\left(\mathrm{CDCl}_{3}, 500 \mathrm{MHz}\right) \delta 6.46(\mathrm{~d}, J=8.2 \mathrm{~Hz}, 1 \mathrm{H}), 7.03(\mathrm{~d}, J=8.2 \mathrm{~Hz}, 1 \mathrm{H}), 7.35(\mathrm{~d}, J=$

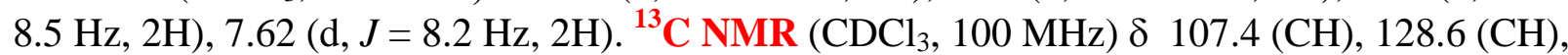
$130.4(\mathrm{CH}), 131.4(\mathrm{CH}), 133.5(\mathrm{C}), 134.2(\mathrm{CH})$. GC-MS (EI) $220\left([\mathrm{M}]^{+},{ }^{81} \mathrm{Br},{ }^{37} \mathrm{Cl} 31 \%\right), 218$ $\left([\mathrm{M}]+{ }^{+} \mathrm{Br},{ }^{35} \mathrm{Cl} \&{ }^{79} \mathrm{Br},{ }^{37} \mathrm{Cl} 100 \%\right), 216\left([\mathrm{M}]+,{ }^{+79} \mathrm{Br},{ }^{35} \mathrm{Cl} 85 \%\right), 139(31 \%), 137(82 \%), 111$ (6\%), $101(61 \%), 75$ (36\%), $50(18 \%)$.

\section{Preparation of $(E)$-1-bromocyclooct-1-ene ${ }^{14}(2 \mathrm{~g})$}

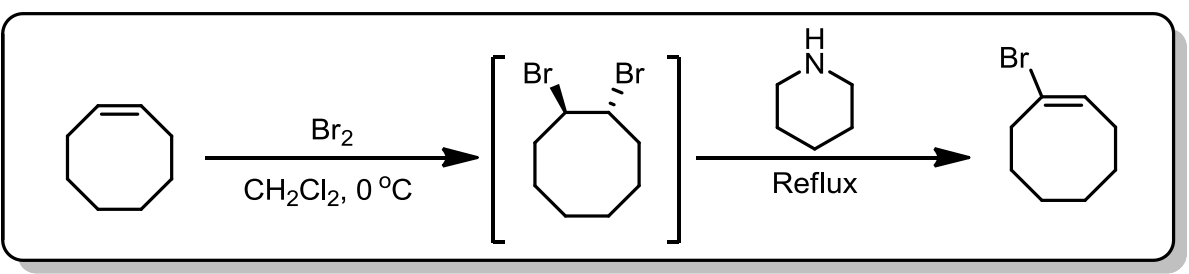

Stage One: Bromination

This procedure is a modification of the procedure outlined by Gassman. ${ }^{14}$ To a $50 \mathrm{~mL}$ round bottom flask equipped with a stir bar was added cyclooctene $(5.00 \mathrm{~g}, 0.045$ mol, 1 equiv) and $\mathrm{CH}_{2} \mathrm{Cl}_{2}(10 \mathrm{~mL})$. The solution was cooled to $0{ }^{\circ} \mathrm{C}$ via an ice bath and stirred for $10 \mathrm{~min} . \mathrm{Br}_{2}(7.2$ $\mathrm{g}, 2.32 \mathrm{~mL}, 1$ equiv) was added to the flask dropwise via a disposable syringe. After complete

\footnotetext{
${ }^{14}$ Gassman, P. G.; Macomber, D. W.; Willging, S. M. J. Am. Chem. Soc. 1985, 107, 2380.
} 
addition of $\mathrm{Br}_{2}$, the solution was allowed to stir at $0{ }^{\circ} \mathrm{C}$ for $5 \mathrm{~min}$. The solution was then warmed to $\mathrm{rt}$ and stirred for $1 \mathrm{~h}$. At this time the solvent was removed in vacuo by rotary evaporation, and the crude bromide (12.15 g, assumed quantitative) was carried on directly to the next step.

\section{Stage Two: Elimination}

The crude bromide from the previous step was transferred to a $50 \mathrm{~mL}$ round bottom flask equipped with a stir bar and reflux condenser. The bromide was dissolved in piperidine $(20 \mathrm{~mL})$, and the solution was heated to reflux via an oil bath. Formation of a voluminous precipitate was observed. After stirring overnight, the crude solution was cooled to rt and filtered through a medium porosity fritted funnel. The crude solids were washed with pentane $(\approx 250 \mathrm{~mL})$. The filtrate was transferred to a separatory funnel and washed sequentially with $1 \mathrm{M} \mathrm{H}_{2} \mathrm{SO}_{4}(2 \times \approx 75$ $\mathrm{mL})$, saturated $\mathrm{NaHCO}_{3}(2 \times \approx 75 \mathrm{~mL})$, deionized $\mathrm{H}_{2} \mathrm{O}(\approx 100 \mathrm{~mL})$, and brine $(\approx 100 \mathrm{~mL})$. The organic layer was dried $\left(\mathrm{Na}_{2} \mathrm{SO}_{4}\right)$, and the solvent was removed in vacuo by rotary evaporation. Further purification was accomplished by vacuum distillation $\left(94-96{ }^{\circ} \mathrm{C} @ 22 \mathrm{~mm} \mathrm{Hg}\right)$ to give the desired alkenyl halide, $\mathbf{2 g}$, as a clear, pale yellow oil (5.32 g, 63\% over 2 steps).

${ }^{1} \mathrm{H}$ NMR $\left(\mathrm{CDCl}_{3}, 500 \mathrm{MHz}\right) \delta 1.47-1.57(\mathrm{~m}, 6 \mathrm{H}), 1.60-1.66(\mathrm{~m}, 2 \mathrm{H}), 2.06-2.13(\mathrm{~m}, 2 \mathrm{H})$, $2.58-2.64(\mathrm{~m}, 2 \mathrm{H}), 6.03(\mathrm{t}, J=8.5 \mathrm{~Hz}, 1 \mathrm{H}) .{ }^{13} \mathrm{C} \mathrm{NMR}\left(\mathrm{CDCl}_{3}, 100 \mathrm{MHz}\right) \delta 25.7\left(\mathrm{CH}_{2}\right), 26.6$ $\left(\mathrm{CH}_{2}\right), 27.7\left(\mathrm{CH}_{2}\right), 28.8\left(\mathrm{CH}_{2}\right), 30.1\left(\mathrm{CH}_{2}\right), 35.3\left(\mathrm{CH}_{2}\right), 125.0(\mathrm{CH}), 131.8(\mathrm{C})$. GC-MS (EI) 190 $\left.([\mathrm{M}]]^{+},{ }^{81} \mathrm{Br} 32 \%\right), 188\left([\mathrm{M}]^{+},{ }^{79} \mathrm{Br} 32 \%\right), 162\left({ }^{81} \mathrm{Br} 14 \%\right), 160\left({ }^{79} \mathrm{Br} 14 \%\right), 148\left({ }^{81} \mathrm{Br} 4 \%\right), 146$ $\left({ }^{79} \mathrm{Br} 4 \%\right), 134\left({ }^{81} \mathrm{Br} 10 \%\right), 132\left({ }^{79} \mathrm{Br} 10 \%\right), 109$ (77\%), $81(48 \%), 79(28 \%), 67(100 \%), 65$ (16\%), 55 (20\%), $53(33 \%)$.

\section{Preparation of $(E)$-1-iodocyclooct-1-ene ${ }^{15}$ via the Barton method $\left(2 g^{\prime}\right)$}

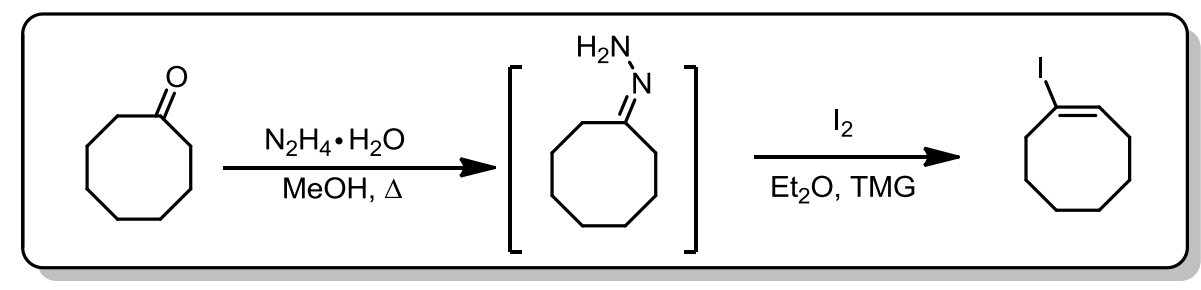

Stage One: Hydrazone formation

This procedure is a modification of the procedure outlined by Yudin. ${ }^{16}$ To a $50 \mathrm{~mL}$ round bottom flask equipped with reflux condenser and stir bar was added cyclooctanone $(6.31 \mathrm{~g}, 0.050 \mathrm{~mol}, 1$ equiv) followed by $\mathrm{MeOH}(8 \mathrm{~mL})$. Hydrazine hydrate $(3.5 \mathrm{~g}, 3.4 \mathrm{~mL}, 0.070 \mathrm{~mol}, 1.4 \mathrm{equiv})$ was added to the flask, and the reaction mixture was heated to reflux for $2 \mathrm{~h}$. After this time, the solution was cooled to $\mathrm{rt}$ and transferred to a separatory funnel. $\mathrm{CH}_{2} \mathrm{Cl}_{2}(100 \mathrm{~mL})$ and deionized $\mathrm{H}_{2} \mathrm{O}(150 \mathrm{~mL})$ were added, and the layers were separated. The aqueous layer was extracted with $\mathrm{CH}_{2} \mathrm{Cl}_{2}(3 \times 75 \mathrm{~mL})$, and the combined organic layers were washed with brine $(200 \mathrm{~mL})$. The organic layer was dried $\left(\mathrm{Na}_{2} \mathrm{SO}_{4}\right)$, and the solvent was removed by rotary evaporation to give the crude hydrazine $(5.53 \mathrm{~g})$, which was used directly in the next step.

\footnotetext{
${ }^{15}$ Kropp, P. J.; McNeely, S. A. Davis, R. D. J. Am. Chem. Soc. 1983, 105, 6907.

${ }^{16}$ Cheung, L. L. W.; Yudin, A. K. Chem. Eur. J. 2010, 16, 4100.
} 
Stage Two: Iodination

To a $250 \mathrm{~mL}$ flame dried, round bottom flask equipped with a stir bar was added $\mathrm{I}_{2}(13.01 \mathrm{~g}$, $0.0573 \mathrm{~mol}, 2.05$ equiv) and anhyd $\mathrm{Et}_{2} \mathrm{O}(25 \mathrm{~mL})$. The flask was sealed with a septum and placed under an argon atmosphere via an inlet needle. The solution was cooled to $0{ }^{\circ} \mathrm{C}$ for $10 \mathrm{~min}$. After this time, TMG (13.53g, 0.117 mol, 4.7 equiv) dissolved in $\mathrm{Et}_{2} \mathrm{O}(16 \mathrm{~mL})$ was added to the flask dropwise. Upon complete addition of TMG, the solution was stirred at $0{ }^{\circ} \mathrm{C}$ for $15 \mathrm{~min}$. After this time, the crude hydrazone ( $3.51 \mathrm{~g}, 0.025 \mathrm{~mol}, 1$ equiv) from the previous step dissolved in $\mathrm{Et}_{2} \mathrm{O}$ $(16 \mathrm{~mL})$ was added dropwise to the solution via a syringe. Upon complete addition of the hydrazone, the solution was stirred at $0{ }^{\circ} \mathrm{C}$ for $15 \mathrm{~min}$. The reaction was quenched with $2 \mathrm{M} \mathrm{HCl}$ $(50 \mathrm{~mL})$ and stirred for $10 \mathrm{~min}$. After this time, saturated $\mathrm{Na}_{2} \mathrm{~S}_{2} \mathrm{O}_{3}(50 \mathrm{~mL})$ was added, and the solution was stirred for an additional $10 \mathrm{~min}$. The now quenched solution was transferred to a separatory funnel, and the layers were separated. The aqueous layer was extracted with pentane $(3 \times 75 \mathrm{~mL})$, and the combined organic layers were washed with $2 \mathrm{M} \mathrm{HCl}(\sim 100 \mathrm{~mL})$, saturated aq $\mathrm{Na}_{2} \mathrm{~S}_{2} \mathrm{O}_{3}(2 \times \sim 100 \mathrm{~mL})$, deionized $\mathrm{H}_{2} \mathrm{O}(\sim 150 \mathrm{~mL})$, and brine $(\sim 150 \mathrm{~mL})$. The organic layer was dried $\left(\mathrm{Na}_{2} \mathrm{SO}_{4}\right)$, and the solvent was removed in vacuo by rotary evaporation. Further purification was accomplished by vacuum distillation $\left(80-82{ }^{\circ} \mathrm{C} @ 2 \mathrm{~mm} \mathrm{Hg}\right)$ to give the alkenyl iodide, $\mathbf{2} \mathbf{g}^{\prime}$ as a clear, yellow oil $(3.00 \mathrm{~g}, 51 \%)$.

${ }^{1} \mathrm{H} \mathrm{NMR}\left(\mathrm{CDCl}_{3}, 500 \mathrm{MHz}\right) \delta 1.44-1.62(\mathrm{~m}, 8 \mathrm{H}), 2.02-2.12(\mathrm{~m}, 2 \mathrm{H}), 2.57-2.70(\mathrm{~m}, 2 \mathrm{H})$, $6.36(\mathrm{t}, J=8.4 \mathrm{~Hz}, 1 \mathrm{H}) .{ }^{13} \mathrm{C} \mathrm{NMR}\left(\mathrm{CDCl}_{3}, 100 \mathrm{MHz}\right) \delta 25.5\left(\mathrm{CH}_{2}\right), 26.8\left(\mathrm{CH}_{2}\right), 27.6\left(\mathrm{CH}_{2}\right)$, $30.0\left(\mathrm{CH}_{2}\right), 30.3\left(\mathrm{CH}_{2}\right), 38.7\left(\mathrm{CH}_{2}\right), 101.0(\mathrm{C}), 141.2(\mathrm{CH})$. GC-MS (EI) $236\left([\mathrm{M}]^{+}, 80 \%\right), 109$ (55\%), 91 (7\%), 81 (25\%), 79 (26\%), 67 (100\%), 65 (12\%), 55 (28\%), 53 (19\%).

Preparation of $(Z)$-3-bromoprop-2-en-1-ol (2j) \& (Z)-((3-bromoallyl)oxy)(tert-butyl)dimethylsilane (2k)

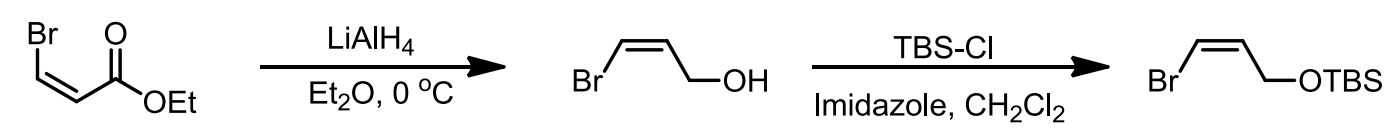

\section{(Z)-3-Bromoprop-2-en-1-ol ${ }^{17}(2 \mathbf{j})$}

This procedure is a modification of the procedure outlined by Taylor. ${ }^{17}$ To a $250 \mathrm{~mL}$ round bottom flask equipped with a stir bar was added $\mathrm{LiAlH}_{4}(1.14 \mathrm{~g}, 0.030 \mathrm{~mol}, 0.75 \mathrm{equiv})$ and anhyd $\mathrm{Et}_{2} \mathrm{O}(80 \mathrm{~mL})$. The flask was sealed with a septum and placed under an argon atmosphere via an inlet needle. The flask was cooled to $0{ }^{\circ} \mathrm{C}$ for $10 \mathrm{~min}$ via an ice bath. At this time, $(Z)$ ethyl 3-bromoacrylate $2 \mathbf{f}$ (7.16 g, 0.040 mol, 1 equiv) was dissolved in anhyd $\mathrm{Et}_{2} \mathrm{O}(20 \mathrm{~mL})$ and added dropwise to the flask via a syringe. After complete addition of the bromide, the solution was allowed to stir at $0{ }^{\circ} \mathrm{C}$ for $90 \mathrm{~min}$. At this time the reaction was quenched by sequential addition of deionized $\mathrm{H}_{2} \mathrm{O}(1.15 \mathrm{~mL}), 2 \mathrm{M} \mathrm{NaOH}(2.30 \mathrm{~mL})$, and again with deionized $\mathrm{H}_{2} \mathrm{O}$ (3.45 mL). CAUTION Evolves excess $\mathrm{H}_{2}$ gas! The solution of the resulting heterogeneous

\footnotetext{
${ }^{17}$ Wei, X.; Taylor, R. J. K. J. Org. Chem., 2000, 65, 616.
} 
mixture was decanted, and the solids were washed with $\mathrm{Et}_{2} \mathrm{O}(2 \times \sim 100 \mathrm{~mL})$. The combined ethereal extracts were transferred to a separatory funnel and washed with deionized $\mathrm{H}_{2} \mathrm{O}(\sim 100$ $\mathrm{mL})$ followed by brine $(\sim 150 \mathrm{~mL})$. The organic layer was dried $\left(\mathrm{Na}_{2} \mathrm{SO}_{4}\right)$, and the solvent was removed in vacuo by rotary evaporation. Further purification was accomplished by vacuum distillation (70-72 ${ }^{\circ} \mathrm{C} @ 5 \mathrm{~mm} \mathrm{Hg}$ ) to give the desired alcohol, $\mathbf{2 \mathbf { j }}$, as a clear, colorless oil (2.52 $\mathrm{g}, 46 \%)$.

${ }^{1} \mathrm{H}$ NMR $\left(\mathrm{CDCl}_{3}, 500 \mathrm{MHz}\right) \delta 4.32(\mathrm{dd}, J=6.1,1.5 \mathrm{~Hz}, 2 \mathrm{H}), 6.27(\mathrm{dt}, J=7.3,1.5 \mathrm{~Hz}, 1 \mathrm{H})$, $6.35(\mathrm{dt}, J=7.3,5.8 \mathrm{~Hz}, 1 \mathrm{H}) .{ }^{13} \mathrm{C}$ NMR $\left(\mathrm{CDCl}_{3}, 100 \mathrm{MHz}\right) \delta 61.2\left(\mathrm{CH}_{2}\right), 109.1(\mathrm{CH}), 134.1$ (CH). GC-MS (EI) $137\left([\mathrm{M}]+{ }^{+}{ }^{81} \mathrm{Br} 4 \%\right), 135\left([\mathrm{M}]+{ }^{+}{ }^{79} \mathrm{Br} 5 \%\right), 107\left({ }^{81} \mathrm{Br} 4 \%\right), 105\left({ }^{79} \mathrm{Br} 3 \%\right), 81$ (4\%), $57(100 \%)$.

\section{(Z)-((3-Bromoallyl)oxy)(tert-butyl)dimethylsilane ${ }^{18}(2 \mathrm{k})$}

This procedure is a modification of the procedure outlined by Davies. ${ }^{19}$ To a $100 \mathrm{~mL}$ round bottom flask equipped with a stir bar was added (Z)-3-bromoprop-2-en-1-ol (0.685 g, 0.005 mol, 1 equiv), tert-butyldimethylsilyl chloride $\left(0.791 \mathrm{~g}, 0.00525 \mathrm{~mol}, 1.05\right.$ equiv), and $\mathrm{CH}_{2} \mathrm{Cl}_{2}$ (25 $\mathrm{mL}$ ). The solution was stirred for $15 \mathrm{~min}$, at which point the solution was homogeneous. At this time, imidazole $(0.374 \mathrm{~g}, 0.0055 \mathrm{~mol}, 1.1$ equiv) was added to the flask, resulting in the immediate formation of a white precipitate. The resulting suspension was stirred overnight at $\mathrm{rt}$. After this time, the solution was quenched with pentane and stirred for an additional $15 \mathrm{~min}$. The resulting heterogeneous solution was filtered through a pad of silica, eluting with $\mathrm{Et}_{2} \mathrm{O}(\sim 250$ $\mathrm{mL})$. The solvent was removed in vacuo, affording the pure silyl ether, $\mathbf{2 k}$, as a clear, colorless oil $(1.22 \mathrm{~g}, 97 \%)$.

${ }^{1} \mathrm{H}$ NMR $\left(\mathrm{CDCl}_{3}, 500 \mathrm{MHz}\right) \delta 0.07-0.11(\mathrm{~m}, 6 \mathrm{H}), 0.89-0.92(\mathrm{~m}, 9 \mathrm{H}), 4.33(\mathrm{dd}, J=5.5,1.8$ $\mathrm{Hz}, 2 \mathrm{H}), 6.16(\mathrm{dt}, J=7.3,1.8 \mathrm{~Hz}, 1 \mathrm{H}), 6.27(\mathrm{dt}, J=7.3,5.5 \mathrm{~Hz}, 1 \mathrm{H}) .{ }^{13} \mathrm{C} \mathrm{NMR}\left(\mathrm{CDCl}_{3}, 100\right.$ $\mathrm{MHz}) \delta-4.96\left(\mathrm{CH}_{3}\right), 18.5(\mathrm{C}), 26.1\left(\mathrm{CH}_{3}\right), 62.2\left(\mathrm{CH}_{2}\right), 106.9(\mathrm{CH}), 135.5(\mathrm{CH})$. GC-MS (EI) $252\left([\mathrm{M}]^{+},{ }^{81} \mathrm{Br} 0.1 \%\right), 250\left([\mathrm{M}]+{ }^{+}{ }^{79} \mathrm{Br} 0.1 \%\right), 195\left({ }^{81} \mathrm{Br} 100 \%\right), 193\left({ }^{79} \mathrm{Br} 99 \%\right), 169\left({ }^{81} \mathrm{Br} 83 \%\right)$, $167\left({ }^{79} \mathrm{Br} 81 \%\right), 139\left({ }^{81} \mathrm{Br} 65 \%\right), 137\left({ }^{79} \mathrm{Br} 62 \%\right), 99$ (13\%), 85\% (11\%), 73 (25\%), 59 (10\%).

${ }^{18}$ Gallagher, W. P.; Maleczka, R. E., Jr. J. Org. Chem. 2005, 70, 841.

${ }^{19}$ Davies, H. M. L.; Hedley, S. J.; Bohall, B. R. J. Org. Chem. 2005, 70, 10737. 


\section{Preparation of $(E)-1-(2-c h l o r o v i n y l)-4-m e t h o x y b e n z e n e^{20}(2 \mathrm{~m})$}

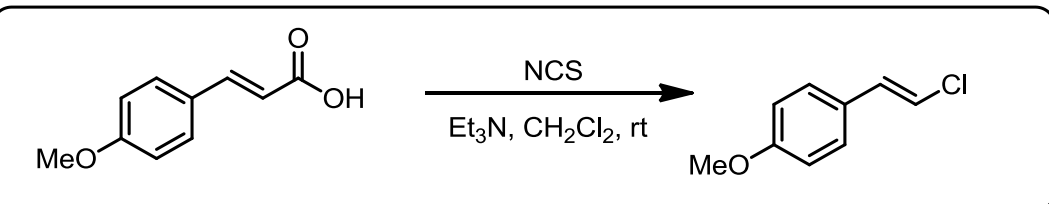

This procedure is a modification of the procedure outlined by Alexakis. ${ }^{21}$ To a $250 \mathrm{~mL}$ round bottom flask equipped with a stir bar was added (E)-3-(4-methoxyphenyl)acrylic acid (3.56 g, 0.020 mol, 1 equiv) and $\mathrm{CH}_{2} \mathrm{Cl}_{2}(67 \mathrm{~mL})$. $\mathrm{Et}_{3} \mathrm{~N}(0.506 \mathrm{~g}, 0.005 \mathrm{~mol}, 0.25$ equiv) was added to the suspension and was stirred for $5 \mathrm{~min}$ at $\mathrm{rt}$. At this time NCS (3.20 g, 0.024 mol, 1.2 equiv) was added all at once, and the reaction was stirred at rt. After 5 min the suspension began to clear and, after $20 \mathrm{~min}$, it became a clear, pale yellow solution. ${ }^{22} \mathrm{CO}_{2}$ evolution was observed during this time. The now clear solution was allowed to stir overnight. After this time, the solvent was removed in vacuo by rotary evaporation, resulting in a crude tan solid. The solid was transferred to a medium porosity fritted funnel and washed with pentane $(\sim 200 \mathrm{~mL})$. The pentane was then removed in vacuo by rotary evaporation, resulting in a semi-solid, which was taken up in a minimum amount of pentane $(\sim 5 \mathrm{~mL})$. Filtration through a short pad of silica followed by eluting with 95:5 hexane/EtOAc afforded a clear pale yellow. Removal of the solvent in vacuo gave the desired alkenyl chloride, $\mathbf{2 m}$, as a clear, pale yellow oil $(2.17 \mathrm{~g}, 64 \%)$.

${ }^{1} \mathrm{H}$ NMR $\left(\mathrm{CDCl}_{3}, 500 \mathrm{MHz}\right) \delta 3.81(\mathrm{~s}, 3 \mathrm{H}), 6.50(\mathrm{~d}, J=13.7 \mathrm{~Hz}, 1 \mathrm{H}), 6.77(\mathrm{~d}, J=13.7 \mathrm{~Hz}$, $1 \mathrm{H}), 6.86(\mathrm{~d}, J=8.5 \mathrm{~Hz}, 2 \mathrm{H}), 7.23(\mathrm{~d}, J=8.5 \mathrm{~Hz}, 2 \mathrm{H}) .{ }^{13} \mathrm{C} \mathrm{NMR}\left(\mathrm{CDCl}_{3}, 100 \mathrm{MHz}\right) \delta 55.5$ $\left(\mathrm{CH}_{3}\right), 114.4(\mathrm{CH}), 116.6(\mathrm{CH}), 127.6(\mathrm{CH}), 127.8(\mathrm{C}), 132.93(\mathrm{CH}), 159.83(\mathrm{C})$. GC-MS (EI) $170\left([\mathrm{M}]+{ }^{+}{ }^{37} \mathrm{Cl} 49 \%\right), 168\left([\mathrm{M}]+{ }^{+}{ }^{35} \mathrm{Cl} 100 \%\right), 155\left({ }^{37} \mathrm{Cl} 28 \%\right), 153\left({ }^{35} \mathrm{Cl} 72 \%\right), 133(17 \%), 127$ $\left({ }^{37} \mathrm{Cl} 28 \%\right), 125\left({ }^{35} \mathrm{Cl} 50 \%\right), 118(6 \%), 118(6 \%), 101(10 \%), 99(12 \%), 89(37 \%), 77$ (6\%). 75 (9\%), $63(20 \%)$.

\section{Preparation of $(Z)$-ethyl 3-chloroacrylate $^{23}(2 n)$}

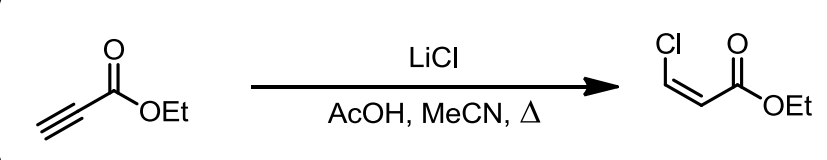

This procedure is a modification of the procedure outlined by $\mathrm{Ma}^{24}$ To a $100 \mathrm{~mL}$ round bottom flask equipped with a stir bar and reflux condenser was added ethyl propiolate $(4.90 \mathrm{~g}, 0.050$ mol, 1 equiv), $\mathrm{LiCl}$ (2.33 g, $0.055 \mathrm{~mol}, 1.1$ equiv), and $\mathrm{MeCN}$ (50 mL). The heterogeneous solution was allowed to stir for $5 \mathrm{~min}$ and, after this time, $\mathrm{AcOH}$ (3.30 g, $0.055 \mathrm{~mol}, 1.1 \mathrm{equiv})$,

\footnotetext{
${ }^{20}$ Bull, J. A.; Mousseau, J. J.; Charette, A. B. Org. Lett. 2008 , 10, 5484.

${ }^{21}$ Mueller, D.; Alexakis, A. Chem. Eur. J. 2013, 19, 15226.

${ }^{22}$ If this induction period does not occur, an additional 0.1-0.2 equiv of $\mathrm{Et}_{3} \mathrm{~N}$ should be added.

${ }^{23}$ Reetz, M. T.; Sommer, K. Eur. J. Org. Chem. 2003, 3485.

${ }^{24}$ Ma, S.; Lu, X.; Li, Z. J. Org. Chem. 1992, 57, 709
} 
dissolved in a minimal amount of $\mathrm{MeCN}(\approx 5 \mathrm{~mL})$, was added. The solution was heated to reflux and stirred for $36 \mathrm{~h}$. Analysis by crude ${ }^{1} \mathrm{H}$ NMR over time indicated that the reaction stalled, and thus additional $\mathrm{LiCl}$ ( $0.639 \mathrm{~g}, 0.015 \mathrm{~mol}, 0.3$ equiv) and $\mathrm{AcOH}(0.901 \mathrm{~g}, 0.015 \mathrm{~mol}, 0.3$ equiv) were added. The solution was allowed to stir for $12 \mathrm{~h}$, and at this time the reaction was still incomplete. Additional $\mathrm{LiCl}(0.639 \mathrm{~g}, 0.015 \mathrm{~mol}, 0.3$ equiv) and $\mathrm{AcOH}(0.901 \mathrm{~g}, 0.015 \mathrm{~mol}, 0.3$ equiv) were added, and the reaction mixture was stirred at reflux for another $24 \mathrm{~h}$. At this time, the reaction was deemed complete and was cooled to rt. The crude reaction mixture was transferred to a separatory funnel and dissolved in pentane $(\sim 100 \mathrm{~mL})$, and saturated aq $\mathrm{NaHCO}_{3}$ $(\sim 100 \mathrm{~mL})$ was added. The layers were separated, and the aqueous layer was extracted with pentane $(3 \times \sim 50 \mathrm{~mL})$. The combined organic layers were washed with saturated aq $\mathrm{NaHCO}_{3}$ $(\sim 150 \mathrm{~mL})$, deionized $\mathrm{H}_{2} \mathrm{O}(2 \times \sim 75 \mathrm{~mL})$, and brine $(\sim 100 \mathrm{~mL})$. The organic layer was dried $\left(\mathrm{Na}_{2} \mathrm{SO}_{4}\right)$, and the solvent was carefully ${ }^{25}$ removed in vacuo by rotary evaporation, giving the desired alkenyl chloride, $2 \mathbf{n}$, as a clear, pale yellow oil (4.53 g, 67\%).

${ }^{1} \mathrm{H}$ NMR $\left(\mathrm{CDCl}_{3}, 500 \mathrm{MHz}\right) \delta 1.30(\mathrm{t}, J=7.6 \mathrm{~Hz}, 3 \mathrm{H}), 4.23(\mathrm{q}, J=7.6 \mathrm{~Hz}, 2 \mathrm{H}), 6.18(\mathrm{~d}, J=8.2$ $\mathrm{Hz}, 1 \mathrm{H}), 6.69(\mathrm{~d}, J=8.2 \mathrm{~Hz}, 1 \mathrm{H}) .{ }^{13} \mathrm{C}$ NMR $\left(\mathrm{CDCl}_{3}, 100 \mathrm{MHz}\right) \delta 14.3\left(\mathrm{CH}_{3}\right), 60.8\left(\mathrm{CH}_{2}\right), 121.6$ (CH), $132.5(\mathrm{CH}), 163.6(\mathrm{C})$. GC-MS (EI) 135 ([M]+, $0.1 \%), 106$ (17\%), 99 (72\%) 91 (54\%), $89(100 \%), 71(10 \%), 63(12 \%), 61(33 \%)$.

\footnotetext{
${ }^{25}$ Note that the alkenyl chloride is highly volatile. Pressures lower than $50 \mathrm{~mm} \mathrm{Hg}$ are not advised.
} 


\section{Synthesis of $R u(b p y)_{3}\left(P_{6}\right)_{2}$ \\ Preparation of the Photocatalyst}

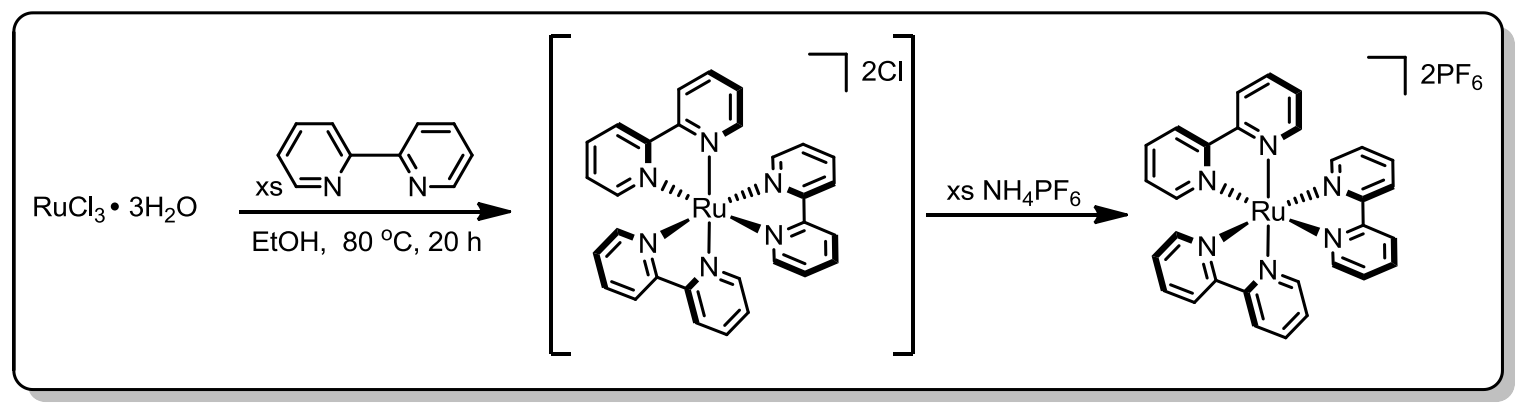

This procedure is a modification of the procedure outlined by Wrighton. ${ }^{26}$ To a $500 \mathrm{~mL}$ round bottom flask equipped with a stir bar and reflux condenser was added 2,2'-bipyridyl (9.68 g, 62.0 mmol, 5.1 equiv) and $\mathrm{RuCl}_{3} \cdot 3 \mathrm{H}_{2} \mathrm{O}(3.16 \mathrm{~g}, 12.1 \mathrm{mmol}, 1.0$ equiv). The system was sealed with a rubber septum and evacuated four times via an inlet needle and purged with $\mathrm{N}_{2}$. Freshly distilled and degassed EtOH (300 mL) was then added, and the solution was heated to reflux via an oil bath. The solution was allowed to stir at reflux for $16 \mathrm{~h}$. The flask was then cooled to rt, and $\mathrm{NH}_{4} \mathrm{PF}_{6}$ (16.30 g, $100 \mathrm{mmol}, 8.3$ equiv) was added, resulting in the formation of a voluminous orange precipitate. The reflux condenser was removed, and the solution was heated $15 \mathrm{~min}$ at 40 ${ }^{\circ} \mathrm{C}$. After this time, the solution was cooled to $\mathrm{rt}$ and then chilled in a refrigerator $\left(\approx 5{ }^{\circ} \mathrm{C}\right)$ overnight. The precipitate was collected by vacuum filtration and washed thoroughly with $\mathrm{H}_{2} \mathrm{O}$ $(\sim 1 \mathrm{~L})$, EtOH $(\sim 300 \mathrm{~mL})$, and finally $\mathrm{Et}_{2} \mathrm{O}(\sim 200 \mathrm{~mL})$ to afford a bright red powder. ${ }^{27} \mathrm{NMR}$ analysis of the solid revealed the presence of a small amount of 2,2'-bipyridyl. To purify the photocatalyst further, the red solid was taken up in hot acetone $(400 \mathrm{~mL})$ and filtered through a pad of Celite ${ }^{\circledR}(10 \times 3 \mathrm{~cm})$, eluting with hot acetone $(\sim 300 \mathrm{~mL})$. The resulting pumpkin orange filtrate was concentrated in vacuo by rotary evaporation to ca. $400 \mathrm{~mL}$, then reagent grade $\mathrm{MeOH}(\sim 200 \mathrm{~mL})$ was added. Rapidly, an orange solid formed, and addition of $\mathrm{Et}_{2} \mathrm{O}(\sim 300 \mathrm{~mL})$ further enhances precipitation of the solid. The precipitate was collected by vacuum filtration, and the pumpkin orange cake was washed thoroughly with $\mathrm{EtOH}(\sim 300 \mathrm{~mL})$ and finally $\mathrm{Et}_{2} \mathrm{O}$ $(\sim 200 \mathrm{~mL})$ to afford the title compound as a fluffy powder $(8.07 \mathrm{~g}, 78 \%)$. Characterization data for this compound matched that reported in the literature. ${ }^{25}$

\footnotetext{
${ }^{26}$ Mabrouk, P. A.; Wrighton, M. S. Inorg. Chem. 1986, 25, 526.

${ }^{27}$ In some cases, NMR analysis of the intermediate brick red solid shows the presence of other complexes, namely $\mathrm{Ru}(\text { bpy })_{3}(\mathrm{Cl})_{2}$ and $\mathrm{Ru}(\mathrm{bpy})_{3}\left(\mathrm{PF}_{6}\right) \mathrm{Cl}$. In these cases, the solid was retaken up in $\mathrm{H}_{2} \mathrm{O}(\sim 200 \mathrm{~mL})$, and $\mathrm{NH}_{4} \mathrm{PF}_{6}(\sim 2$ equiv) was added. The resulting suspension was sonicated at $\mathrm{rt}$ for $30 \mathrm{~min}$ then filtered, affording a brick red cake that was purified using the above mentioned procedure.
} 


\section{General Procedures for Photoredox Cross-coupling of Alkenes}

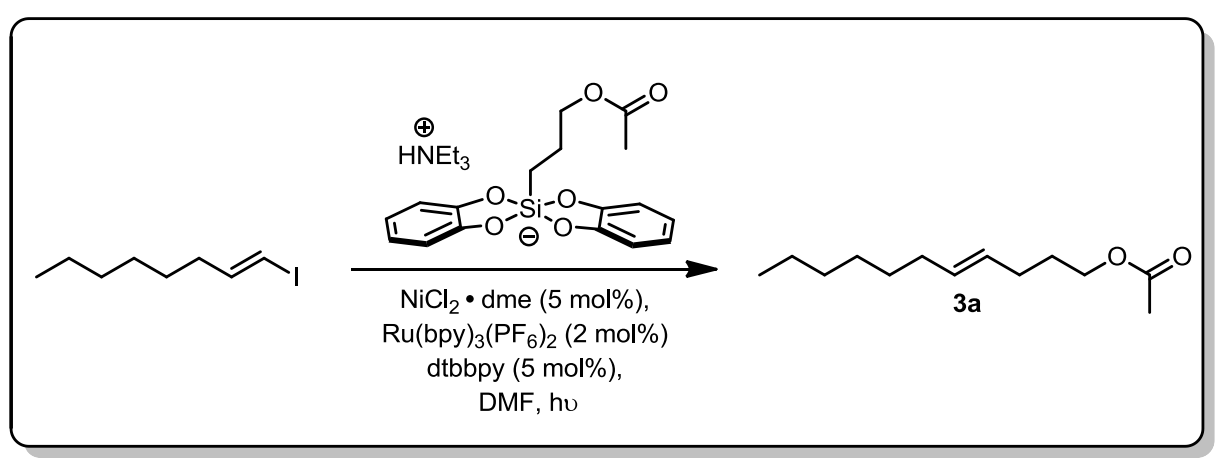

General Procedure A: Systems lacking Lewis basic functional groups and/or possessing low polarity

\section{(E)-Undec-4-en-1-yl Acetate (3a)}

To an $8 \mathrm{~mL}$ reaction vial equipped with an appropriately sized stir bar were added the silicate 1a (268 mg, $0.6 \mathrm{mmol}, 1.2$ equiv), $\mathrm{NiCl}_{2} \bullet \mathrm{dme}$ ( $5.5 \mathrm{mg}, 0.025 \mathrm{mmol}, 0.05$ equiv), dtbbpy (6.7 $\mathrm{mg}$, $0.025,0.05$ equiv), and $\mathrm{Ru}(\mathrm{bpy})_{3}\left(\mathrm{PF}_{6}\right)(8.6 \mathrm{mg}, 0.01 \mathrm{mmol}, 0.02$ equiv). The vial was sealed with a cap containing a TFE-lined silicone septa and was evacuated three times via an inlet needle and purged with argon. The vial was then charged via a syringe with the iodide $2 \mathbf{a}$ (119 $\mathrm{mg}, 0.5$ mmol, 1 equiv) dissolved in anhyd, degassed DMF $(5 \mathrm{~mL})$. The cap was sealed with Parafilm, and the now bright red solution was irradiated in the aforementioned LED reactor. The temperature of the reaction was maintained at approximately $27{ }^{\circ} \mathrm{C}$ via a fan. The solution was stirred vigorously while being irradiated. Reaction progress was monitored by GC/MS. Once judged to be complete, the now opaque, milky-brown solution was transferred to a separatory funnel and diluted with deionized $\mathrm{H}_{2} \mathrm{O}(\sim 20 \mathrm{~mL})$ and $\mathrm{Et}_{2} \mathrm{O}(\sim 20 \mathrm{~mL})$. The layers were separated, ${ }^{28}$ and the aqueous layer was extracted with $\mathrm{Et}_{2} \mathrm{O}(3 \times \sim 20 \mathrm{~mL})$. The combined organic layers were washed with $2 \mathrm{M} \mathrm{NaOH}(2 \times \sim 30 \mathrm{~mL}), 2 \mathrm{M} \mathrm{HCl}(\sim 30 \mathrm{~mL})$, deionized $\mathrm{H}_{2} \mathrm{O}(\sim 30$ $\mathrm{mL})$, and brine $(\sim 50 \mathrm{~mL})$. The organic layer was dried $\left(\mathrm{Na}_{2} \mathrm{SO}_{4}\right)$, and the solvent was removed in vacuo by rotary evaporation. Further purification was accomplished by passing the crude material over a pad of silica, eluting with two volumes of hexane and discarding the eluate followed by 95:5 to 9:1 hexane/EtOAc to give the desired alkene, 3a, as a clear, colorless oil (62 $\mathrm{mg}, 58 \%)$.

${ }^{1} \mathrm{H}$ NMR $\left(\mathrm{CDCl}_{3}, 500 \mathrm{MHz}\right) \delta 0.88(\mathrm{t}, J=7.1 \mathrm{~Hz}, 3 \mathrm{H}), 1.22-1.35(\mathrm{~m}, 8 \mathrm{H}), 1.64-1.72(\mathrm{~m}, 2 \mathrm{H})$, $1.97(\mathrm{q}, J=6.7 \mathrm{~Hz}, 2 \mathrm{H}), 2.04(\mathrm{~s}, 3 \mathrm{H}), 2.05(\mathrm{q}, J=6.7 \mathrm{~Hz}, 2 \mathrm{H}), 4.06(\mathrm{t}, J=6.7 \mathrm{~Hz}, 2 \mathrm{H}), 5.31-$ $5.50(\mathrm{~m}, 2 \mathrm{H}) .{ }^{13} \mathrm{C} \mathrm{NMR}\left(\mathrm{CDCl}_{3}, 125 \mathrm{MHz}\right) \delta 14.4\left(\mathrm{CH}_{3}\right), 21.3\left(\mathrm{CH}_{3}\right), 22.9\left(\mathrm{CH}_{2}\right), 28.7\left(\mathrm{CH}_{2}\right)$, $29.1\left(\mathrm{CH}_{2}\right), 29.8\left(\mathrm{CH}_{2}\right), 32.0\left(\mathrm{CH}_{2}\right), 32.8\left(\mathrm{CH}_{2}\right), 64.3\left(\mathrm{CH}_{2}\right), 128.9(\mathrm{CH}), 131.9\left(\mathrm{CH}_{2}\right), 171.5(\mathrm{C})$. GC-MS (EI) 212 ([M] $\left.{ }^{+}, 0.1 \%\right), 152$ (38\%), 124 (10\%), 110 (17\%), 95 (31\%), 81 (80\%), 79 (20\%), 68 (100\%), 55 (30\%). HRMS (CI+) calcd for $\mathrm{C}_{13} \mathrm{H}_{25} \mathrm{O}_{2}[\mathrm{M}+\mathrm{H}]^{+}: 213.1855$, found: 213.1845 .

\footnotetext{
${ }^{28}$ Note that a precipitate will often form and rest at the interface between the organic and aqueous layers. It can be discarded during the washes without compromising yield.
} 


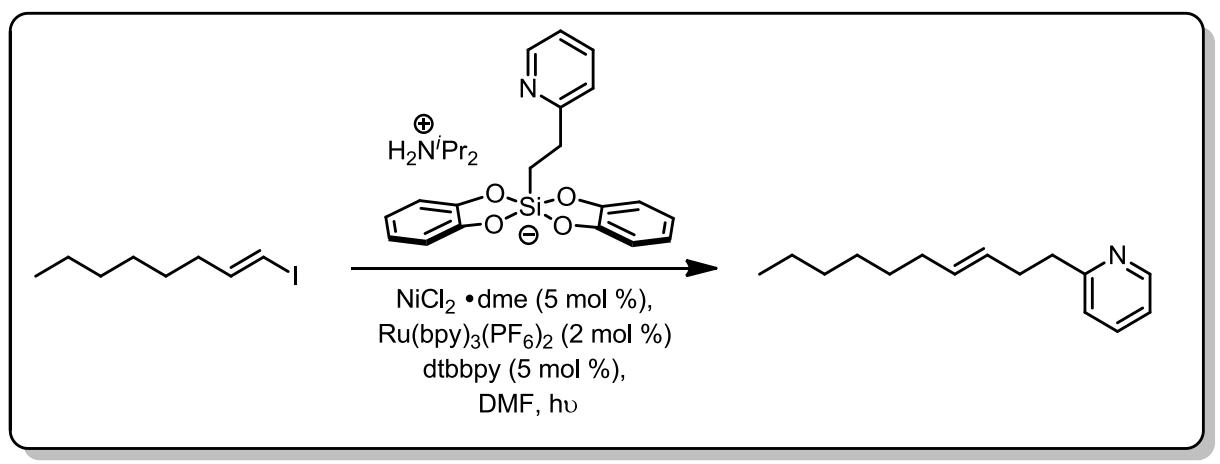

\section{General Procedure B: Systems with Lewis basic functional groups}

\section{(E)-2-(Dec-3-en-1-yl)pyridine (3v)}

To an $8 \mathrm{~mL}$ reaction vial equipped with an appropriately sized stir bar were added the silicate $\mathbf{1 l}$ (272 mg, $0.6 \mathrm{mmol}, 1.2$ equiv), $\mathrm{NiCl}_{2} \bullet \mathrm{dme}(5.5 \mathrm{mg}, 0.025 \mathrm{mmol}, 0.05$ equiv), dtbbpy ( $6.7 \mathrm{mg}$, $0.025,0.05$ equiv), and $\mathrm{Ru}(\mathrm{bpy})_{3}\left(\mathrm{PF}_{6}\right)(8.6 \mathrm{mg}, 0.01 \mathrm{mmol}, 0.02$ equiv). The vial was sealed with a cap containing a TFE-lined silicone septa and was evacuated three times via an inlet needle and purged with argon. The vial was then charged via a syringe with the iodide, $2 \mathbf{2 a}(119 \mathrm{~g}, 0.5 \mathrm{mmol}$, 1 equiv) dissolved in anhyd, degassed DMF (5 mL). The cap was sealed with Parafilm, and the now bright red solution was irradiated in the aforementioned LED reactor. The temperature of the reaction was maintained at approximately $27{ }^{\circ} \mathrm{C}$ via a fan. The solution was stirred vigorously while being irradiated. Reaction progress was monitored by GC/MS. Once judged to be complete, the now opaque, milky-brown solution was transferred to a separatory funnel and diluted with $2 \mathrm{M} \mathrm{NaOH}(\sim 20 \mathrm{~mL})$ and $\mathrm{Et}_{2} \mathrm{O}(\sim 20 \mathrm{~mL})$. The layers were separated, ${ }^{29}$ and the aqueous layer was extracted with $\mathrm{Et}_{2} \mathrm{O}(3 \times \sim 20 \mathrm{~mL})$. The combined organic layers were washed with $2 \mathrm{M} \mathrm{NaOH}(\sim 30 \mathrm{~mL})$, deionized $\mathrm{H}_{2} \mathrm{O}(\sim 30 \mathrm{~mL})$, and brine $(\sim 50 \mathrm{~mL})$. The organic layer was dried $\left(\mathrm{Na}_{2} \mathrm{SO}_{4}\right)$, and the solvent was removed in vacuo by rotary evaporation. Further purification was accomplished by passing the crude material over a pad of silica, eluting with two volumes of hexane and discarding the eluate followed by 95:5 to 9:1 hexane/EtOAc to give the desired alkene, $\mathbf{3 v}$, as a clear, colorless oil (78 $\mathrm{mg}, 72 \%)$.

${ }^{1} \mathrm{H} \mathrm{NMR}\left(\mathrm{CDCl}_{3}, 500 \mathrm{MHz}\right) \delta 0.87(\mathrm{t}, J=6.8 \mathrm{~Hz}, 3 \mathrm{H}), 1.17-1.34(\mathrm{~m}, 8 \mathrm{H}), 1.89-2.01(\mathrm{~m}, 2 \mathrm{H})$, $2.36-2.46(\mathrm{~m}, 2 \mathrm{H}), 2.84(\mathrm{t}, J=7.9 \mathrm{~Hz}, 2 \mathrm{H}), 5.35-5.50(\mathrm{~m}, 2 \mathrm{H}), 7.08(\mathrm{dd}, J=7.3,4.8 \mathrm{~Hz}, 1 \mathrm{H})$, $7.12(\mathrm{~d}, J=7.9 \mathrm{~Hz}, 1 \mathrm{H}), 7.57(\mathrm{td}, J=7.7,1.6 \mathrm{~Hz}, 1 \mathrm{H}), 8.52(\mathrm{dt}, J=4.8,0.9 \mathrm{~Hz}, 1 \mathrm{H}) .{ }^{13} \mathrm{C}$ NMR $\left(\mathrm{CDCl}_{3}, 125 \mathrm{MHz}\right) \delta 14.3\left(\mathrm{CH}_{3}\right), 22.9\left(\mathrm{CH}_{2}\right), 29.0\left(\mathrm{CH}_{2}\right), 29.7\left(\mathrm{CH}_{2}\right), 32.0\left(\mathrm{CH}_{2}\right), 32.8\left(\mathrm{CH}_{2}\right)$, 33.0 $\left(\mathrm{CH}_{2}\right), 38.7\left(\mathrm{CH}_{2}\right), 121.1(\mathrm{CH}), 123.1(\mathrm{CH}), 129.1(\mathrm{CH}), 131.7(\mathrm{CH}), 136.3(\mathrm{CH}), 149.5$ $(\mathrm{CH}), 162.0(\mathrm{C})$. GC-MS (EI) $217\left([\mathrm{M}]^{+}, 7 \%\right) 188(7 \%), 160(6 \%), 146(100 \%), 132(46 \%)$, 130 (11\%), 119 (20\%), 117 (23\%), 93 (43\%), 79 (4\%) 65 (7\%), 55 (3\%). HRMS (ES+) calcd for $\mathrm{C}_{15} \mathrm{H}_{24} \mathrm{~N}[\mathrm{M}+\mathrm{H}]^{+}: 218.1909$, found: 218.1917.

\footnotetext{
${ }^{29}$ Note that a precipitate will often form and rest at the interface between the organic and aqueous layers. It can be discarded during the washes without compromising yield.
} 


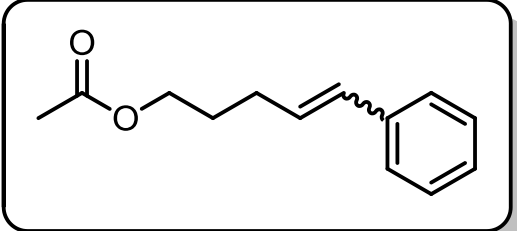

5-Phenylpent-4-en-1-yl Acetate, ${ }^{30}$ 3b $(65 \mathrm{mg}, 63 \%)$ was prepared according to General Procedure A for photoredox cross-coupling of bromoalkene $\mathbf{2 b}(92 \mathrm{mg}, 0.5 \mathrm{mmol}$, cis:trans ratio 1:13.3). The desired cross-coupled alkene was obtained as a clear, light yellow oil (cis:trans ratio 1:11.1). ${ }^{1} \mathbf{H}$ NMR $\left(\mathrm{CDCl}_{3}, 500 \mathrm{MHz}\right) \delta 1.78-1.86(\mathrm{~m}, 2 \mathrm{H}), 2.06(\mathrm{~s}, 3 \mathrm{H})$, $2.29(\mathrm{q}, J=7.6 \mathrm{~Hz}, 2 \mathrm{H}), 4.12(\mathrm{t}, J=6.6 \mathrm{~Hz}, 2 \mathrm{H}), 6.20(\mathrm{dt}, J=15.7,7.0 \mathrm{~Hz}, 1 \mathrm{H}), 6.41(\mathrm{~d}, J=$ $15.9 \mathrm{~Hz}, 1 \mathrm{H}), 7.20(\mathrm{t}, J=7.3 \mathrm{~Hz}, 1 \mathrm{H}), 7.26-7.36(\mathrm{~m}, 4 \mathrm{H}) .{ }^{13} \mathrm{C} \mathrm{NMR}\left(\mathrm{CDCl}_{3}, 125 \mathrm{MHz}\right) \delta 21.2$ $\left(\mathrm{CH}_{3}\right), 28.6\left(\mathrm{CH}_{2}\right), 29.6\left(\mathrm{CH}_{2}\right), 64.2\left(\mathrm{CH}_{2}\right), 126.2(\mathrm{CH}), 127.3(\mathrm{CH}), 128.8(\mathrm{CH}), 129.6(\mathrm{CH})$, $130.9(\mathrm{CH}), 137.8(\mathrm{C}), 171.4$ (C). GC-MS (EI) 204 ([M] $\left.]^{+}, 0.4 \%\right), 144$ (54\%), $129(100 \%), 117$ (18\%), 115 (27\%), 91 (20\%), 77 (4\%), 66 (4\%), 51 (3\%). HRMS (ES+) calcd for $\mathrm{C}_{13} \mathrm{H}_{16} \mathrm{O}_{2} \mathrm{Na}$ $[\mathrm{M}+\mathrm{Na}]^{+}: 227.1048$, found: 227.1050 .

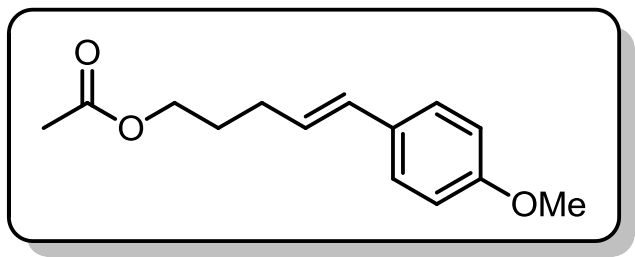

(E)-5-(4-Methoxyphenyl)pent-4-en-1-yl Acetate, 3c (99 $\mathrm{mg}, 84 \%$ ) was prepared according to General Procedure A for photoredox cross-coupling of bromoalkene $2 \mathbf{c}$ ( $107 \mathrm{mg}, 0.5 \mathrm{mmol})$. The desired crosscoupled alkene was obtained as a clear, colorless oil. ${ }^{1} \mathbf{H}$ NMR $\left(\mathrm{CDCl}_{3}, 500 \mathrm{MHz}\right) \delta 1.76-1.84(\mathrm{~m}, 2 \mathrm{H}), 2.05$ (s, 3H), $2.26(\mathrm{q}, J=7.3 \mathrm{~Hz}, 2 \mathrm{H}), 3.80(\mathrm{~s}, 3 \mathrm{H}), 4.11(\mathrm{t}, J=6.6 \mathrm{~Hz}, 2 \mathrm{H}), 6.05(\mathrm{dt}, J=15.6,7.1 \mathrm{~Hz}$, $1 \mathrm{H}), 6.35(\mathrm{~d}, J=15.6 \mathrm{~Hz}, 1 \mathrm{H}), 6.83(\mathrm{~d}, J=8.8 \mathrm{~Hz}, 2 \mathrm{H}), 7.26(\mathrm{~d}, J=8.3 \mathrm{~Hz}, 2 \mathrm{H}) .{ }^{13} \mathrm{C}$ NMR $\left(\mathrm{CDCl}_{3}, 125 \mathrm{MHz}\right) \delta 21.2\left(\mathrm{CH}_{3}\right), 28.7\left(\mathrm{CH}_{2}\right), 29.6\left(\mathrm{CH}_{2}\right), 55.5\left(\mathrm{CH}_{3}\right), 64.2\left(\mathrm{CH}_{2}\right), 114.2(\mathrm{CH})$, $127.3(\mathrm{CH}), 127.4(\mathrm{CH}), 130.3(\mathrm{CH}), 130.6(\mathrm{C}), 159.0(\mathrm{C}), 171.43(\mathrm{C})$. GC-MS (EI) $234\left([\mathrm{M}]^{+}\right.$, 88\%), 174 (100\%), 159 (87\%), 147 (84\%), 143 (71\%), 131 (29\%), 128 (20\%), $121(29 \%), 115$ (39\%), 103 (17\%), 91 (43\%), 77 (14\%), 65 (6\%), 55 (3\%), 53 (3\%). HRMS (ES+) calcd for $\mathrm{C}_{14} \mathrm{H}_{19} \mathrm{O}_{3}[\mathrm{M}+\mathrm{H}]^{+}: 235.1334$, found: 235.1344 .

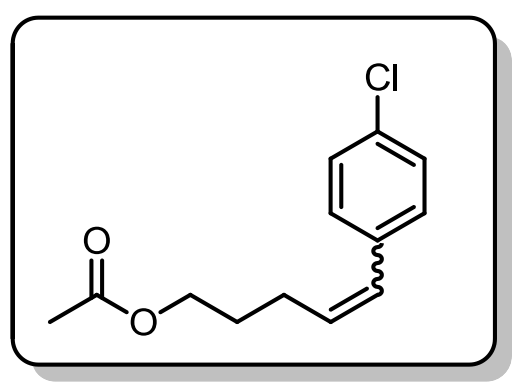

(Z)-5-(4-Chlorophenyl)pent-4-en-1-yl Acetate, 3d (105 mg, $87 \%$ ) was prepared according to General Procedure A for photoredox cross-coupling of bromoalkene $2 \mathbf{d}$ (109 mg, 0.5 mmol). The desired cross-coupled alkene was obtained as a clear, yellow oil. ${ }^{1} \mathrm{H}$ NMR $\left(\mathrm{CDCl}_{3}, 500 \mathrm{MHz}\right) \delta 1.74-1.82$ $(\mathrm{m}, 2 \mathrm{H}), 2.00$ (s, 3H), $2.37(\mathrm{qd}, J=7.4,1.8 \mathrm{~Hz}, 2 \mathrm{H}), 4.07$ (t, $J=$ $6.6 \mathrm{~Hz}, 2 \mathrm{H}), 5.66(\mathrm{dt}, J=11.7,7.3 \mathrm{~Hz}, 1 \mathrm{H}), 6.41(\mathrm{~d}, J=11.7$ $\mathrm{Hz}, 1 \mathrm{H}), 7.18(\mathrm{~d}, J=8.5 \mathrm{~Hz}, 2 \mathrm{H}), 7.30(\mathrm{~d}, J=8.5 \mathrm{~Hz}, 2 \mathrm{H}) .{ }^{13} \mathrm{C}$ NMR $\left(\mathrm{CDCl}_{3}, 125 \mathrm{MHz}\right) \delta 21.0\left(\mathrm{CH}_{3}\right), 25.1\left(\mathrm{CH}_{2}\right), 28.9$ $\left(\mathrm{CH}_{2}\right), 63.9\left(\mathrm{CH}_{2}\right), 128.5(\mathrm{CH}), 128.9(\mathrm{CH}), 130.2(\mathrm{CH}), 132.2(\mathrm{CH}), 132.6(\mathrm{C}), 136.0(\mathrm{C}), 171.2$ (C). GC-MS (EI) $\left.240([\mathrm{M}]]^{+},{ }^{37} \mathrm{Cl} 1 \%\right), 238\left([\mathrm{M}]{ }^{+},{ }^{35} \mathrm{Cl} 2 \%\right), 180\left({ }^{37} \mathrm{Cl} 10 \%\right), 178\left({ }^{35} \mathrm{Cl} 29 \%\right), 165$ $\left({ }^{37} \mathrm{Cl}, 5 \%\right), 163\left({ }^{35} \mathrm{Cl} 13 \%\right), 151$ (8\%), 143 (100\%), 128 (40\%), 115 (25\%), 89 (4\%), 75 (3\%). HRMS (CI+) calcd for $\mathrm{C}_{13} \mathrm{H}_{15} \mathrm{ClO}_{2}[\mathrm{M}]+: 238.0761$, found: 238.0762 .

\footnotetext{
${ }^{30}$ Roman,S. A.; Closson,W. D. J. Am. Chem. Soc. 1969, 91, 1701.
} 


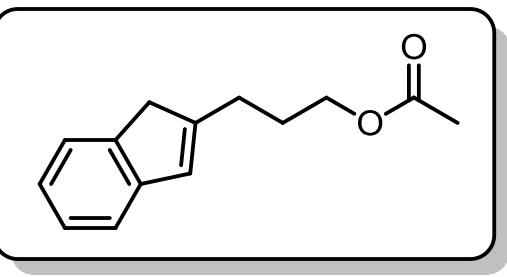

3-(1H-Inden-2-yl)propyl Acetate, 3e (98 mg, 90\%) was prepared according to General Procedure A for photoredox cross-coupling of bromoalkene $2 \mathrm{e}(98 \mathrm{mg}, 0.5 \mathrm{mmol})$. The desired cross-coupled alkene was obtained as a clear, pale yellow oil. ${ }^{1} \mathrm{H}$ NMR $\left(\mathrm{CDCl}_{3}, 500 \mathrm{MHz}\right) \delta 1.96(\mathrm{dt}, J=15.2$, $6.6 \mathrm{~Hz}, 2 \mathrm{H}), 2.05(\mathrm{~s}, 3 \mathrm{H}), 2.56(\mathrm{t}, J=7.5 \mathrm{~Hz}, 2 \mathrm{H}), 3.32(\mathrm{~s}$, $2 \mathrm{H}), 4.13(\mathrm{t}, J=6.6 \mathrm{~Hz}, 2 \mathrm{H}), 6.53(\mathrm{~s}, 1 \mathrm{H}), 7.10(\mathrm{td}, J=7.4$, $1.2 \mathrm{~Hz}, 1 \mathrm{H}), 7.22(\mathrm{t}, J=7.5 \mathrm{~Hz}, 1 \mathrm{H}), 7.27(\mathrm{~d}, J=7.3 \mathrm{~Hz}, 1 \mathrm{H}), 7.37(\mathrm{dd}, J=7.3,0.4 \mathrm{~Hz}, 1 \mathrm{H}) .{ }^{13} \mathrm{C}$ NMR $\left(\mathrm{CDCl}_{3}, 125 \mathrm{MHz}\right) \delta 21.2\left(\mathrm{CH}_{3}\right), 27.8\left(\mathrm{CH}_{2}\right), 28.2\left(\mathrm{CH}_{2}\right), 41.3\left(\mathrm{CH}_{2}\right), 64.3\left(\mathrm{CH}_{2}\right), 120.3$ $(\mathrm{CH}), 123.7(\mathrm{CH}), 124.0(\mathrm{CH}), 126.6(\mathrm{CH}), 127.0(\mathrm{CH}), 143.2(\mathrm{C}), 145.6(\mathrm{C}), 149.3(\mathrm{C}), 171.4$ (C). GC-MS (EI) $216\left([\mathrm{M}]^{+}, 35 \%\right), 156(87 \%), 141$ (81\%), 128 (100\%), $115(52 \%), 102(5 \%)$, $91(5 \%), 77(5 \%), 63(4 \%), 51(3 \%)$. HRMS (ES+) calcd for $\mathrm{C}_{14} \mathrm{H}_{16} \mathrm{O}_{2} \mathrm{Na}[\mathrm{M}+\mathrm{Na}]^{+}: 239.1048$, found: 239.1055 .

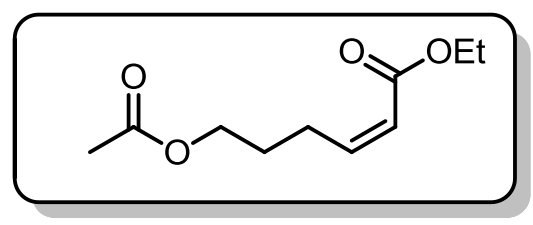

(Z)-Ethyl 6-Acetoxyhex-2-enoate, 3f (66 mg, 66\%) was prepared according to General Procedure A for photoredox cross-coupling of bromoalkene $2 \mathbf{f}$ ( $90 \mathrm{mg}, 0.5 \mathrm{mmol})$. The desired cross-coupled alkene was obtained as a clear, colorless oil. ${ }^{1} \mathrm{H}$ NMR $\left(\mathrm{CDCl}_{3}, 500 \mathrm{MHz}\right) \delta 1.29(\mathrm{td}, J=7.1,0.9 \mathrm{~Hz}$, 3H), $1.75-1.83(\mathrm{~m}, J=7.1 \mathrm{~Hz}, 2 \mathrm{H}), 2.05(\mathrm{~d}, J=0.9 \mathrm{~Hz}, 3 \mathrm{H}), 2.74(\mathrm{q}, J=7.3 \mathrm{~Hz}, 2 \mathrm{H}), 4.09(\mathrm{t}, J$ $=6.5 \mathrm{~Hz}, 2 \mathrm{H}), 4.17(\mathrm{qd}, J=7.1,0.9 \mathrm{~Hz}, 2 \mathrm{H}), 5.78-5.82(\mathrm{~m}, 1 \mathrm{H}), 6.21(\mathrm{dt}, J=11.6,7.6 \mathrm{~Hz}, 1 \mathrm{H})$. ${ }^{13} \mathrm{C} \mathrm{NMR}\left(\mathrm{CDCl}_{3}, 125 \mathrm{MHz}\right) \delta 14.5\left(\mathrm{CH}_{3}\right), 21.2\left(\mathrm{CH}_{3}\right), 25.7\left(\mathrm{CH}_{2}\right), 28.2\left(\mathrm{CH}_{2}\right), 60.1\left(\mathrm{CH}_{2}\right)$, $64.1\left(\mathrm{CH}_{2}\right), 120.9(\mathrm{CH}), 148.8(\mathrm{CH}), 166.5(\mathrm{C}), 171.4(\mathrm{C})$. GC-MS (EI) $200\left([\mathrm{M}]^{+}, 0.1 \%\right), 158$ (12\%), 140 (38\%), 127 (16\%), 125 (14\%), 113 (100\%), 99 (21\%), 97 (63\%), 94 (84\%), 86 (10\%), $84(50 \%), 81(15 \%), 71(10 \%), 67$ (74\%), 55 (16\%), 53 (13\%). HRMS (ES+) calcd for $\mathrm{C}_{10} \mathrm{H}_{17} \mathrm{O}_{4}[\mathrm{M}+\mathrm{H}]^{+}:$201.1127, found: 201.1122 .

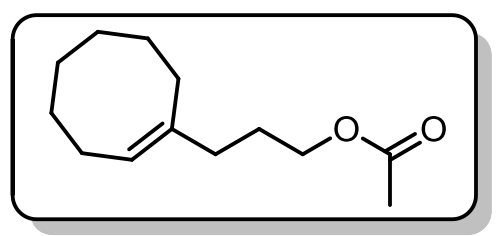

(E)-3-(Cyclooct-1-en-1-yl)propyl Acetate, 3g (83 mg, 77\%) was prepared according to General Procedure A for photoredox cross-coupling of bromoalkene $\mathbf{2 g}$ (95 $\mathrm{mg}, 0.5 \mathrm{mmol}$ ). The desired cross-coupled alkene was obtained as a clear, pale yellow oil. ${ }^{1} \mathrm{H}$ NMR $\left(\mathrm{CDCl}_{3}, 500 \mathrm{MHz}\right) \delta 1.43-1.54(\mathrm{~m}, 8 \mathrm{H})$, $1.74(\mathrm{dt}, J=14.9,6.7 \mathrm{~Hz}, 2 \mathrm{H}), 2.01-2.10(\mathrm{~m}, 4 \mathrm{H}), 2.05(\mathrm{~s}, 3 \mathrm{H})$, $2.12-2.16(\mathrm{~m}, 2 \mathrm{H}), 4.06(\mathrm{t}, J=6.7 \mathrm{~Hz}, 2 \mathrm{H}), 5.35(\mathrm{t}, J=8.2 \mathrm{~Hz}, 1 \mathrm{H}) .{ }^{13} \mathrm{C} \mathrm{NMR}\left(\mathrm{CDCl}_{3}, 125\right.$ $\mathrm{MHz}) \delta 21.3\left(\mathrm{CH}_{3}\right), 26.5\left(\mathrm{CH}_{2}\right), 26.5\left(\mathrm{CH}_{2}\right), 26.8\left(\mathrm{CH}_{2}\right), 27.2\left(\mathrm{CH}_{2}\right), 29.1\left(\mathrm{CH}_{2}\right), 29.1\left(\mathrm{CH}_{2}\right)$, $30.2\left(\mathrm{CH}_{2}\right), 33.8\left(\mathrm{CH}_{2}\right), 64.7\left(\mathrm{CH}_{2}\right), 124.6(\mathrm{CH}), 139.7(\mathrm{C}), 171.5(\mathrm{C})$. GC-MS (EI) 210 $\left([\mathrm{M}]^{+}, 0.1 \%\right), 150(58 \%), 135$ (24\%), 122 (100\%), 109 (29\%), 107 (44\%), 95 (35\%) 93 (59\%), $91(17 \%), 81(54 \%), 79(62 \%), 77(16 \%), 67$ (70\%), 55 (25\%), 53 (12\%). HRMS (CI+) calcd for $\mathrm{C}_{13} \mathrm{H}_{23} \mathrm{O}_{2}[\mathrm{M}+\mathrm{H}]^{+}:$211.1698, found: 211.1707.

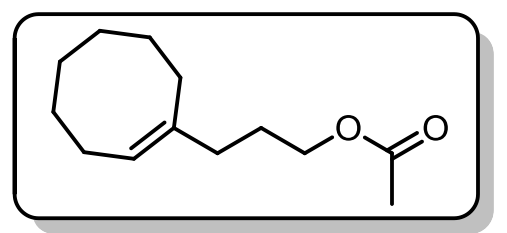

(E)-3-(Cyclooct-1-en-1-yl)propyl Acetate, 3g (71 mg, 70\%) was prepared according to General Procedure A for photoredox cross-coupling of iodoalkene $\mathbf{2 g ^ { \prime }}$ (118 $\left.\mathrm{mg}, 0.5 \mathrm{mmol}\right)$. The desired cross-coupled alkene was obtained as a clear, pale yellow oil. ${ }^{1} \mathrm{H}$ NMR $\left(\mathrm{CDCl}_{3}, 500 \mathrm{MHz}\right) \delta 1.43-1.54(\mathrm{~m}, 8 \mathrm{H})$, $1.74(\mathrm{dt}, J=14.9,6.7 \mathrm{~Hz}, 2 \mathrm{H}), 2.01-2.10(\mathrm{~m}, 4 \mathrm{H}), 2.05$ (s, 3H), 
$2.12-2.16(\mathrm{~m}, 2 \mathrm{H}), 4.06(\mathrm{t}, J=6.7 \mathrm{~Hz}, 2 \mathrm{H}), 5.35(\mathrm{t}, J=8.2 \mathrm{~Hz}, 1 \mathrm{H}) .{ }^{13} \mathrm{C} \mathrm{NMR}\left(\mathrm{CDCl}_{3}, 125\right.$ MHz) $\delta 21.3\left(\mathrm{CH}_{3}\right), 26.5\left(\mathrm{CH}_{2}\right), 26.5\left(\mathrm{CH}_{2}\right), 26.8\left(\mathrm{CH}_{2}\right), 27.2\left(\mathrm{CH}_{2}\right), 29.1\left(\mathrm{CH}_{2}\right), 29.1\left(\mathrm{CH}_{2}\right)$, $30.2\left(\mathrm{CH}_{2}\right), 33.8\left(\mathrm{CH}_{2}\right), 64.7\left(\mathrm{CH}_{2}\right), 124.6(\mathrm{CH}), 139.7(\mathrm{C}), 171.5(\mathrm{C})$. GC-MS (EI) 210 $\left([\mathrm{M}]^{+}, 0.1 \%\right), 150(58 \%), 135$ (24\%), 122 (100\%), 109 (29\%), 107 (44\%), 95 (35\%) 93 (59\%), 91 (17\%), 81 (54\%), 79 (62\%), 77 (16\%), 67 (70\%), 55 (25\%), 53 (12\%) HRMS (CI+) calcd for $\mathrm{C}_{13} \mathrm{H}_{23} \mathrm{O}_{2}[\mathrm{M}+\mathrm{H}]^{+}: 211.1698$, found: 211.1707.

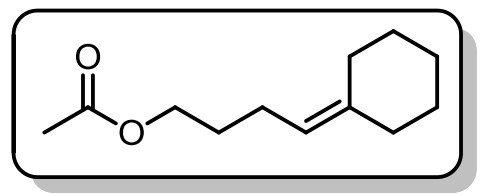

4-Cyclohexylidenebutyl Acetate, $\mathbf{3 h}$ (73 mg, 74\%) was prepared according to General Procedure A for photoredox cross-coupling of bromoalkene $2 \mathbf{h}(88 \mathrm{mg}, 0.5 \mathrm{mmol})$. The desired cross-coupled alkene was obtained as a clear, colorless oil. ${ }^{1} \mathrm{H}$ NMR $\left(\mathrm{CDCl}_{3}\right.$, $500 \mathrm{MHz}) \delta 1.44-1.57(\mathrm{~m}, 6 \mathrm{H}), 1.61-1.69(\mathrm{~m}, 2 \mathrm{H}), 2.03-2.08$ (m, 4H), $2.04(\mathrm{~s}, 3 \mathrm{H}), 2.10(\mathrm{t}, J=5.8 \mathrm{~Hz}, 2 \mathrm{H}), 4.05(\mathrm{t}, J=6.7 \mathrm{~Hz}, 2 \mathrm{H}), 5.04(\mathrm{t}, J=7.4 \mathrm{~Hz}, 1 \mathrm{H})$. ${ }^{13} \mathrm{C}$ NMR $\left(\mathrm{CDCl}_{3}, 125 \mathrm{MHz}\right) \delta 21.3\left(\mathrm{CH}_{3}\right), 23.5\left(\mathrm{CH}_{2}\right), 27.1\left(\mathrm{CH}_{2}\right), 28.0\left(\mathrm{CH}_{2}\right), 28.9\left(\mathrm{CH}_{2}\right)$, $28.9\left(\mathrm{CH}_{2}\right), 29.1\left(\mathrm{CH}_{2}\right), 37.4\left(\mathrm{CH}_{2}\right), 64.3\left(\mathrm{CH}_{2}\right), 119.9(\mathrm{CH}), 141.0(\mathrm{C}), 171.5(\mathrm{C}) . \mathrm{GC}-\mathrm{MS}(\mathrm{EI})$ $196\left([\mathrm{M}]^{+}, 1 \%\right), 136(89 \%), 121(48 \%), 107(100 \%), 93(72 \%), 91(22 \%), 81(64 \%), 79(98 \%)$, $77(20 \%), 67(80 \%), 65(10 \%), 55(28 \%)$. HRMS (ES+) calcd for $\mathrm{C}_{12} \mathrm{H}_{20} \mathrm{O}_{2} \mathrm{Na}[\mathrm{M}+\mathrm{Na}]^{+}$: 219.1361, found: 219.1361 .

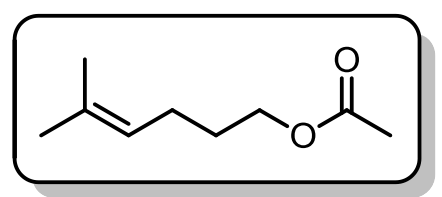

5-Methylhex-4-en-1-yl Acetate, ${ }^{31}$ 3i (31 mg, 48\%) was prepared according to General Procedure A for photoredox cross-coupling of bromoalkene $2 \mathbf{i}(68 \mathrm{mg}, 0.5 \mathrm{mmol})$. The desired cross-coupled alkene was obtained as a clear, colorless oil. ${ }^{1} \mathrm{H}$ NMR $\left(\mathrm{CDCl}_{3}, 500\right.$ $\mathrm{MHz}) \delta 1.60(\mathrm{~s}, 3 \mathrm{H}), 1.62-1.70(\mathrm{~m}, 2 \mathrm{H}), 1.69(\mathrm{~s}, 3 \mathrm{H}), 2.05(\mathrm{q}, J=$ $7.6 \mathrm{~Hz}, 2 \mathrm{H}), 2.05(\mathrm{~s}, 3 \mathrm{H}), 4.05(\mathrm{t}, J=6.7 \mathrm{~Hz}, 2 \mathrm{H}), 5.07-5.12(\mathrm{~m}, 1 \mathrm{H}) .{ }^{13} \mathrm{C} \mathbf{N M R}\left(\mathrm{CDCl}_{3}, 125\right.$ MHz) $\delta 17.8\left(\mathrm{CH}_{3}\right), 21.3\left(\mathrm{CH}_{3}\right), 24.5\left(\mathrm{CH}_{2}\right), 25.9\left(\mathrm{CH}_{3}\right), 28.9\left(\mathrm{CH}_{2}\right), 64.3\left(\mathrm{CH}_{2}\right), 123.4(\mathrm{CH})$, 132.8 (C), 171.5 (C). GC-MS (EI) 156 ([M] $\left.]^{+}, 0.1 \%\right), 96$ (49\%), 81 (100\%), 79 (10\%), 69 (14\%), $67(12 \%), 55(10 \%), 53(6 \%)$.

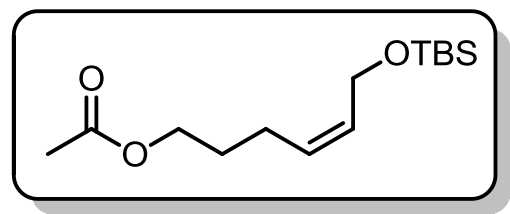

(Z)-6-((tert-Butyldimethylsilyl)oxy)hex-4-en-1-yl Acetate, 3k $(121 \mathrm{mg}, 88 \%)$ was prepared according to General Procedure A for photoredox cross-coupling of bromoalkene $2 \mathbf{k}(126 \mathrm{mg}, 0.5$ $\mathrm{mmol}$ ). The desired cross-coupled alkene was obtained as a clear, colorless oil. ${ }^{1} \mathrm{H}$ NMR $\left(\mathrm{CDCl}_{3}, 500 \mathrm{MHz}\right) \delta 0.07$ (s, $6 \mathrm{H}), 0.90(\mathrm{~s}, 9 \mathrm{H}), 1.66-1.74(\mathrm{~m}, 2 \mathrm{H}), 2.05(\mathrm{~s}, 3 \mathrm{H}), 2.12(\mathrm{q}, J=7.3 \mathrm{~Hz}, 2 \mathrm{H}), 4.06(\mathrm{t}, J=6.6 \mathrm{~Hz}$, $2 \mathrm{H}), 4.22(\mathrm{dt}, J=6.1,0.8 \mathrm{~Hz}, 2 \mathrm{H}), 5.37-5.46(\mathrm{~m}, 1 \mathrm{H}), 5.52-5.61(\mathrm{~m}, 1 \mathrm{H}) .{ }^{13} \mathrm{C} \mathrm{NMR}\left(\mathrm{CDCl}_{3}\right.$, $125 \mathrm{MHz}) \delta-4.9\left(\mathrm{CH}_{3}\right), 18.6(\mathrm{C}), 21.2\left(\mathrm{CH}_{3}\right), 24.2\left(\mathrm{CH}_{2}\right), 26.2\left(\mathrm{CH}_{3}\right), 28.7\left(\mathrm{CH}_{2}\right), 59.5\left(\mathrm{CH}_{2}\right)$, $64.1\left(\mathrm{CH}_{2}\right), 129.5(\mathrm{CH}), 130.9(\mathrm{CH}), 171.3(\mathrm{C})$. GC-MS (EI) $272\left([\mathrm{M}]^{+}, 0.1 \%\right), 215(22 \%), 173$ (9\%), 159 (4\%), 117 (100\%), 99 (6\%), 81 (69\%), 79 (18\%), 75 (55\%), 73 (19\%), 59 (5\%), 53 (5\%). HRMS (ES+) calcd for $\mathrm{C}_{14} \mathrm{H}_{28} \mathrm{O}_{3} \mathrm{SiNa}[\mathrm{M}+\mathrm{Na}]^{+}: 295.1705$, found: 295.1704 .

\footnotetext{
${ }^{31}$ Wang, Z. J.; Jackson, W. R.; Robinson, A. J. Org. Lett. 2013, 15, 3006.
} 


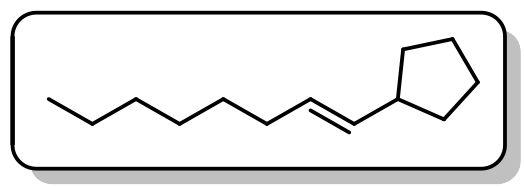

(E)-Oct-1-en-1-ylcyclopentane, ${ }^{32}$ 31 (62 mg, 68\%) was prepared according to General Procedure A for photoredox cross-coupling of iodoalkene $\mathbf{2 a}(119 \mathrm{mg}, 0.5 \mathrm{mmol})$ and cyclopentylsilicate $\mathbf{1 b}$ ( $249 \mathrm{mg}, 0.006 \mathrm{~mol}, 1.2$ equiv) with the following modifications: 1) Pentane was used in place of $\mathrm{Et}_{2} \mathrm{O}$ during the extraction. 2) Pentane was used as the eluant for the $\mathrm{SiO}_{2}$ plug. The desired crosscoupled alkene was obtained as a clear, colorless oil. ${ }^{1} \mathbf{H} \mathbf{N M R}\left(\mathrm{CDCl}_{3}, 500 \mathrm{MHz}\right) \delta 0.88(\mathrm{t}, J=$ $7.0 \mathrm{~Hz}, 3 \mathrm{H}), 1.20-1.38(\mathrm{~m}, 10 \mathrm{H}), 1.49-1.58(\mathrm{~m}, 2 \mathrm{H}), 1.58-1.68(\mathrm{~m}, 2 \mathrm{H}), 1.70-1.79(\mathrm{~m}, 2 \mathrm{H})$, $1.92-2.00(\mathrm{~m}, 2 \mathrm{H}), 2.32-2.43(\mathrm{~m}, 1 \mathrm{H}), 5.30-5.46(\mathrm{~m}, 2 \mathrm{H}) .{ }^{13} \mathrm{C} \mathrm{NMR}\left(\mathrm{CDCl}_{3}, 125 \mathrm{MHz}\right) \delta$ $14.4\left(\mathrm{CH}_{3}\right), 22.9\left(\mathrm{CH}_{2}\right), 25.4\left(\mathrm{CH}_{2}\right), 29.1\left(\mathrm{CH}_{2}\right), 29.9\left(\mathrm{CH}_{2}\right), 32.0\left(\mathrm{CH}_{2}\right), 32.8\left(\mathrm{CH}_{2}\right), 33.5\left(\mathrm{CH}_{2}\right)$, $43.6(\mathrm{CH}), 128.7(\mathrm{CH}), 135.2(\mathrm{CH})$. GC-MS (EI) $180\left([\mathrm{M}]^{+}, 23 \%\right), 123(10 \%), 109(11 \%), 85$ $(87 \%), 82$ (67\%), $79(18 \%), 67$ (100\%), 55 (24\%). HRMS (CI+) calcd for $\mathrm{C}_{13} \mathrm{H}_{24}\left[\mathrm{M}^{+}\right.$: 180.1878, found: 180.1871

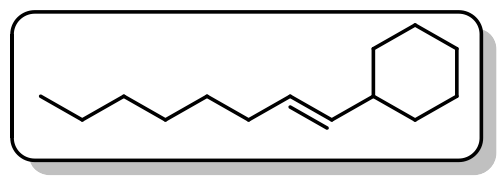

(E)-Oct-1-en-1-ylcyclohexane, ${ }^{33} \mathbf{3 m}(72 \mathrm{mg}, \quad 74 \%)$ was prepared according to General Procedure A for photoredox cross-coupling of iodoalkene $\mathbf{2 a}(119 \mathrm{mg}, 0.5 \mathrm{mmol})$ and cyclohexylsilicate 1c (258 mg, $0.006 \mathrm{~mol}, 1.2$ equiv) with the following modifications: 1) Pentane was used in place of $\mathrm{Et}_{2} \mathrm{O}$ during the extraction 2) Pentane was used as the eluant for the $\mathrm{SiO}_{2}$ plug. The desired crosscoupled alkene was obtained as a clear, colorless oil. ${ }^{1} \mathrm{H}$ NMR $\left(\mathrm{CDCl}_{3}, 500 \mathrm{MHz}\right) \delta 0.88(\mathrm{t}, J=$ $7.3 \mathrm{~Hz}, 3 \mathrm{H}), 1.04(\mathrm{qd}, J=12.4,4.0 \mathrm{~Hz}, 2 \mathrm{H}), 1.15$ (tt, $J=12.3,3.2 \mathrm{~Hz}, 1 \mathrm{H}), 1.20-1.35(\mathrm{~m}, 10 \mathrm{H})$, $1.60-1.65(\mathrm{~m}, 1 \mathrm{H}), 1.66-1.73(\mathrm{~m}, 4 \mathrm{H}), 1.88(\mathrm{t}, J=11.1 \mathrm{~Hz}, 1 \mathrm{H}), 1.93-1.99(\mathrm{~m}, 2 \mathrm{H}), 5.28-$ $5.40(\mathrm{~m}, 2 \mathrm{H}) .{ }^{13} \mathrm{C} \mathrm{NMR}\left(\mathrm{CDCl}_{3}, 125 \mathrm{MHz}\right) \delta 14.3\left(\mathrm{CH}_{3}\right), 22.9\left(\mathrm{CH}_{2}\right), 26.4\left(\mathrm{CH}_{2}\right), 26.5\left(\mathrm{CH}_{2}\right)$, $29.1\left(\mathrm{CH}_{2}\right), 29.9\left(\mathrm{CH}_{2}\right), 32.0\left(\mathrm{CH}_{2}\right), 32.9\left(\mathrm{CH}_{2}\right), 33.6\left(\mathrm{CH}_{2}\right), 40.9(\mathrm{CH}), 128.0(\mathrm{CH}), 136.6(\mathrm{CH})$. GC-MS (EI) $194\left([\mathrm{M}]^{+}, 40 \%\right), 166$ (4\%), 138 (4\%) 124 (7\%), 109 (68\%), 96 (100\%), 81 (95\%), 79 (20\%), 67 (93\%), 55 (36\%). HRMS (CI+) calcd for $\mathrm{C}_{14} \mathrm{H}_{26}[\mathrm{M}]^{+}:$194.2035, found: 194.2034.

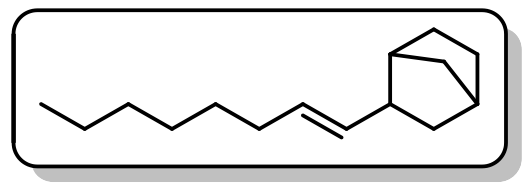

(E)-2-(Oct-1-en-1-yl)bicyclo[2.2.1]heptane, $( \pm)-3 n$ (78 mg, $76 \%$ ) was prepared according to General Procedure A for photoredox cross-coupling of iodoalkene $2 \mathbf{a}(119 \mathrm{mg}, 0.5$ $\mathrm{mmol})$ and bicycloheptylsilicate 1d (265 mg, $0.006 \mathrm{~mol}, 1.2$ equiv) with the following modifications: 1) Pentane was used in place of $\mathrm{Et}_{2} \mathrm{O}$ during the extraction. 2) Pentane was used as the eluant for the $\mathrm{SiO}_{2}$ plug. The desired cross-coupled alkene was obtained as a clear, colorless oil. ${ }^{1} \mathrm{H}$ NMR $\left(\mathrm{CDCl}_{3}, 500\right.$ $\mathrm{MHz}) \delta 0.88(\mathrm{t}, J=6.9 \mathrm{~Hz}, 3 \mathrm{H}), 1.05-1.17(\mathrm{~m}, 2 \mathrm{H}), 1.18-1.36(\mathrm{~m}, 11 \mathrm{H}), 1.41-1.53(\mathrm{~m}, 3$ $\mathrm{H}), 1.89$ - 2.08 (m, $4 \mathrm{H}), 2.20$ (br s, $1 \mathrm{H}), 5.29-5.32$ (m, $2 \mathrm{H}) .{ }^{13} \mathrm{C} \mathrm{NMR}\left(\mathrm{CDCl}_{3}, 125 \mathrm{MHz}\right) \delta$ $14.3\left(\mathrm{CH}_{3}\right), 22.9\left(\mathrm{CH}_{2}\right), 29.1\left(\mathrm{CH}_{2}\right), 29.3\left(\mathrm{CH}_{2}\right), 29.9\left(\mathrm{CH}_{2}\right), 30.0\left(\mathrm{CH}_{2}\right), 32.0\left(\mathrm{CH}_{2}\right), 32.8\left(\mathrm{CH}_{2}\right)$, $35.8\left(\mathrm{CH}_{2}\right), 36.9(\mathrm{CH}), 38.3\left(\mathrm{CH}_{2}\right), 43.1(\mathrm{CH}), 45.2(\mathrm{CH}), 128.0(\mathrm{CH}), 136.3(\mathrm{CH}) . \mathrm{GC}-\mathrm{MS}(\mathrm{EI})$ $206\left([\mathrm{M}]^{+}, 28 \%\right), 178(8 \%), 149(18 \%), 135(13 \%), 121(63 \%), 110(10 \%), 108(13 \%), 95$ (56\%), 91 (19\%), 82 (18\%), 80 (100\%), 77 (16\%), 67 (78\%), 55 (22\%). HRMS (CI+) calcd for $\mathrm{C}_{15} \mathrm{H}_{26}[\mathrm{M}]^{+}: 206.2035$, found: 206.2038 .

\footnotetext{
${ }^{32}$ Brown, H. C.; Basavaiah, D. J. Org. Chem. 1982, 47, 754.

${ }^{33}$ Noble, A.; McCarver, S. J.; MacMillan, D. W. C. J. Am. Chem. Soc. 2015, 137, 624.
} 


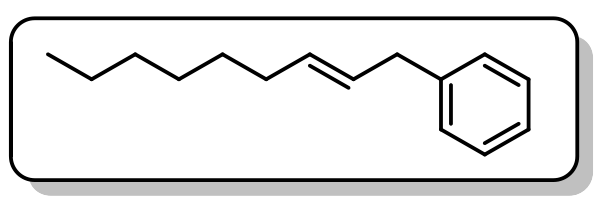

(E)-Non-2-en-1-ylbenzene, ${ }^{33}$ 3o $(71 \mathrm{mg}, 70 \%)$ was prepared according to General Procedure A for photoredox cross-coupling of iodoalkene $\mathbf{2 a}(119 \mathrm{mg}, 0.5$ mmol) and benzylpentylsilicate 1e $(263 \mathrm{mg}, 0.006 \mathrm{~mol}$, 1.2 equiv) with the following modifications: 1) Pentane was used in place of $\mathrm{Et}_{2} \mathrm{O}$ during the extraction. 2) Pentane was used as the eluant for the $\mathrm{SiO}_{2}$ plug. The desired cross-coupled alkene was obtained as a clear, colorless oil. ${ }^{1} \mathbf{H}$ NMR $\left(\mathrm{CDCl}_{3}\right.$, $500 \mathrm{MHz}) \delta 0.89(\mathrm{t}, J=6.7 \mathrm{~Hz}, 3 \mathrm{H}), 1.21-1.33(\mathrm{~m}, 6 \mathrm{H}), 1.33-1.41(\mathrm{~m}, 2 \mathrm{H}), 2.03(\mathrm{q}, J=6.8 \mathrm{~Hz}$, $2 \mathrm{H}), 3.34(\mathrm{~d}, J=6.1 \mathrm{~Hz}, 2 \mathrm{H}), 5.44-5.62(\mathrm{~m}, 2 \mathrm{H}), 7.17-7.21(\mathrm{~m}, 3 \mathrm{H}), 7.29(\mathrm{t}, J=7.6 \mathrm{~Hz}, 2 \mathrm{H})$. ${ }^{13} \mathrm{C} \mathrm{NMR}\left(\mathrm{CDCl}_{3}, 125 \mathrm{MHz}\right) \delta 14.3\left(\mathrm{CH}_{3}\right), 22.9\left(\mathrm{CH}_{2}\right), 29.1\left(\mathrm{CH}_{2}\right), 29.7\left(\mathrm{CH}_{2}\right), 32.0\left(\mathrm{CH}_{2}\right)$, $32.8\left(\mathrm{CH}_{2}\right), 39.3\left(\mathrm{CH}_{2}\right), 126.1(\mathrm{CH}), 128.6(\mathrm{CH}), 128.7(\mathrm{CH}), 128.9(\mathrm{CH}), 132.4(\mathrm{CH}), 141.4$ (C). GC-MS (EI) 202 ([M] $\left.]^{+}, 31 \%\right), 131$ (11\%), 129 (10\%), 117 (70\%), $115(18 \%), 104$ (100\%) $91(53 \%), 77(5 \%), 69(8 \%), 55$ (5\%). HRMS (CI+) calcd for $\mathrm{C}_{15} \mathrm{H}_{22}[\mathrm{M}]^{+}: 202.1722$, found: 202.1724 .

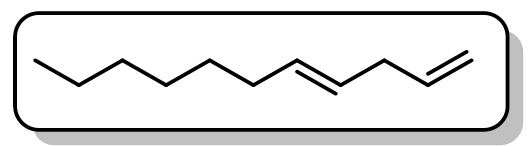

(E)-Undeca-1,4-diene, ${ }^{34}$ 3p (26 $\left.\mathrm{mg}, 32 \%\right)$ was prepared according to General Procedure A for photoredox crosscoupling of iodoalkene $\mathbf{2 a}(119 \mathrm{mg}, 0.5 \mathrm{mmol})$ and benzylpentylsilicate 1f (233 mg, $0.006 \mathrm{~mol}, 1.2$ equiv) with the following modifications: 1) Pentane was used in place of $\mathrm{Et}_{2} \mathrm{O}$ during the extraction. 2) Pentane was used as the eluant for the $\mathrm{SiO}_{2}$ plug. The desired cross-coupled alkene was obtained as a clear, colorless oil. ${ }^{1} \mathrm{H}$ NMR $\left(\mathrm{CDCl}_{3}, 500 \mathrm{MHz}\right) \delta 0.88(\mathrm{t}, J=7.1 \mathrm{~Hz}, 3 \mathrm{H}), 1.16-1.43(\mathrm{~m}, 8 \mathrm{H})$, $2.00(\mathrm{q}, J=7.1 \mathrm{~Hz}, 2 \mathrm{H}), 2.67-2.78(\mathrm{~m}, 2 \mathrm{H}), 4.97(\mathrm{ddt}, J=10.1,2.1,1.1 \mathrm{~Hz}, 1 \mathrm{H}), 5.02(\mathrm{dq}, J=$ $17.1,1.7 \mathrm{~Hz}, 1 \mathrm{H}), 5.33-5.52(\mathrm{~m}, 2 \mathrm{H}), 5.83(\mathrm{ddt}, J=16.9,10.2,6.4 \mathrm{~Hz}, 1 \mathrm{H}) .{ }^{13} \mathrm{C} \mathrm{NMR}\left(\mathrm{CDCl}_{3}\right.$, $125 \mathrm{MHz}) \delta 14.3\left(\mathrm{CH}_{3}\right), 22.9\left(\mathrm{CH}_{2}\right), 29.1\left(\mathrm{CH}_{2}\right), 29.7\left(\mathrm{CH}_{2}\right), 32.0\left(\mathrm{CH}_{2}\right), 32.8\left(\mathrm{CH}_{2}\right), 37.0$ $\left(\mathrm{CH}_{2}\right), 114.9\left(\mathrm{CH}_{2}\right), 127.7$ (s, $\left.4 \mathrm{C}\right), 132.1$ (s, $\left.4 \mathrm{C}\right), 137.8$ (s, $\left.3 \mathrm{C}\right)$. GC-MS (EI) $152\left([\mathrm{M}]^{+}, 16 \%\right)$, 124 (13\%), 110 (14\%), 95 (29\%), 81 (83\%), 79 (44\%), 67 (100\%), 54 (84\%). HRMS (APCI) calcd for $\mathrm{C}_{11} \mathrm{H}_{20}[\mathrm{M}]^{+}:$152.1565, found: 152.1559 .

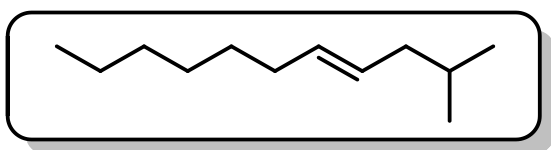

(E)-2-Methylundec-4-ene, 3q (72 mg, 86\%) was prepared according to General Procedure A for photoredox crosscoupling of iodoalkene $\mathbf{2 a}(119 \mathrm{mg}, 0.5 \mathrm{mmol})$ and isobutylpentylsilicate $1 \mathrm{~g}$ (242 $\mathrm{mg}, 0.006 \mathrm{~mol}, 1.2$ equiv)

with the following modifications: 1) Pentane was used in place of $\mathrm{Et}_{2} \mathrm{O}$ during the extraction. 2) Pentane was used as the eluant for the $\mathrm{SiO}_{2}$ plug. The desired cross-coupled alkene was obtained as a clear, colorless oil. ${ }^{1} \mathrm{H}$ NMR $\left(\mathrm{CDCl}_{3}, 500 \mathrm{MHz}\right) \delta 0.87(\mathrm{~d}, J=6.4 \mathrm{~Hz}, 6 \mathrm{H}), 0.88(\mathrm{t}, J=6.7$ $\mathrm{Hz}, 3 \mathrm{H}), 1.17-1.38(\mathrm{~m}, 8 \mathrm{H}), 1.57$ (sept, $J=6.8 \mathrm{~Hz}, 1 \mathrm{H}), 1.86(\mathrm{t}, J=5.6 \mathrm{~Hz}, 2 \mathrm{H}), 1.98(\mathrm{q}, J=$ $5.2 \mathrm{~Hz}, 2 \mathrm{H}), 5.32-5.43(\mathrm{~m}, 2 \mathrm{H}) .{ }^{13} \mathrm{C} \mathrm{NMR}\left(\mathrm{CDCl}_{3}, 125 \mathrm{MHz}\right) \delta 14.3\left(\mathrm{CH}_{3}\right), 22.5\left(\mathrm{CH}_{3}\right), 22.9$ $\left(\mathrm{CH}_{2}\right), 28.8\left(\mathrm{CH}_{2}\right), 29.1\left(\mathrm{CH}_{2}\right), 29.9(\mathrm{CH}), 32.0\left(\mathrm{CH}_{2}\right), 32.9\left(\mathrm{CH}_{2}\right), 42.3\left(\mathrm{CH}_{2}\right), 129.2(\mathrm{CH})$, $131.9(\mathrm{CH})$. GC-MS (EI) $168\left([\mathrm{M}]^{+}, 34 \%\right), 153(3 \%), 112(9 \%), 97(20 \%), 83(48 \%), 69$ (100\%), $56(93 \%)$ HRMS (CI+) calcd for $\mathrm{C}_{12} \mathrm{H}_{25}[\mathrm{M}+\mathrm{H}]^{+}:$169.1956, found: 169.1950 .

\footnotetext{
${ }^{34}$ Wilson, S. R.; Zucker, P. A. J. Org. Chem. 1988, 53, 4682.
} 


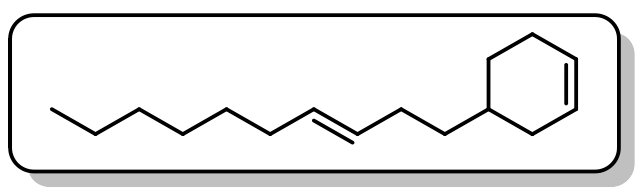

(E)-4-(Dec-3-en-1-yl)cyclohex-1-ene, $3 \mathbf{r} \quad(88 \quad \mathrm{mg}$, $80 \%$ ) was prepared according to General Procedure A for photoredox cross-coupling of iodoalkene $\mathbf{2 a}$ (119 $\mathrm{mg}, 0.5 \mathrm{mmol})$ and (2-(3-cyclohexenyl)ethyl)silicate 1h (263 mg, $0.006 \mathrm{~mol}, 1.2$ equiv) with the following modifications: 1) Pentane was used in place of $\mathrm{Et}_{2} \mathrm{O}$ during the extraction. 2) Pentane was used as the eluant for the $\mathrm{SiO}_{2}$ plug. The desired cross-coupled alkene was obtained as a clear, colorless oil. ${ }^{1} \mathrm{H}$ NMR $\left(\mathrm{CDCl}_{3}, 500 \mathrm{MHz}\right) \delta 0.88(\mathrm{t}, J=6.7 \mathrm{~Hz}, 3 \mathrm{H}), 1.17-1.38(\mathrm{~m}, 11 \mathrm{H}), 1.50$ - 1.59 (m, 1H), 1.60 - $1.68(\mathrm{~m}, 1 \mathrm{H}), 1.70$ - 1.77 (m, 1H), 1.94 - 1.99 (m, 2H), 2.00 - 2.06 (m, 4H), $2.06-2.13(\mathrm{~m}, 1 \mathrm{H}), 5.34-5.46(\mathrm{~m}, 2 \mathrm{H}), 5.65(\mathrm{~s}, 2 \mathrm{H}),{ }^{13} \mathrm{C} \mathrm{NMR}\left(\mathrm{CDCl}_{3}, 125 \mathrm{MHz}\right) \delta 14.3$ $\left(\mathrm{CH}_{3}\right), 22.9\left(\mathrm{CH}_{2}\right), 25.5\left(\mathrm{CH}_{2}\right), 29.1\left(\mathrm{CH}_{2}, \mathrm{CH}\right.$ overlapping $), 29.9\left(\mathrm{CH}_{2}\right), 30.2\left(\mathrm{CH}_{2}\right), 32.0\left(\mathrm{CH}_{2}\right)$, $32.1\left(\mathrm{CH}_{2}\right), 32.9\left(\mathrm{CH}_{2}\right), 33.2\left(\mathrm{CH}_{2}\right), 36.9\left(\mathrm{CH}_{2}\right), 126.9(\mathrm{CH}), 127.3(\mathrm{CH}), 130.6(\mathrm{CH}), 130.6$ (CH). GC-MS (EI) 220 ([M] $\left.]^{+}, 14 \%\right), 178$ (14\%), 135 (31\%), $121(64 \%), 107$ (18\%), 94 (45\%), 91 (12\%), 79 (100\%), 69 (13\%), 67 (44\%), 55 (27\%). HRMS (CI+) calcd for $\mathrm{C}_{16} \mathrm{H}_{28}[\mathrm{M}]^{+}$: 220.2191, found: 220.2182 .

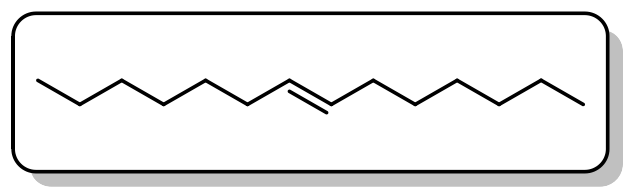

(E)-Tetradec-7-ene, ${ }^{35}$ 3s $(61 \mathrm{mg}, 62 \%)$ was prepared according to General Procedure A for photoredox crosscoupling of iodoalkene $2 \mathbf{a}(119 \mathrm{mg}, 0.5 \mathrm{mmol})$ and (2hexylsilicate $1 \mathrm{i}$ (263 $\mathrm{mg}, 0.006 \mathrm{~mol}, 1.2$ equiv) with the following modifications: 1) Pentane was used in place of $\mathrm{Et}_{2} \mathrm{O}$ during the extraction. 2) Pentane was used as the eluant for the $\mathrm{SiO}_{2}$ plug. The desired cross-coupled alkene was obtained as a clear, colorless oil. ${ }^{1} \mathbf{H} \mathbf{N M R}\left(\mathrm{CDCl}_{3}, 500 \mathrm{MHz}\right) \delta 0.88$ $(\mathrm{t}, J=7.0 \mathrm{~Hz}, 6 \mathrm{H}) 1.18-1.41(\mathrm{~m}, 16 \mathrm{H}) 1.85-2.06(\mathrm{~m}, 4 \mathrm{H}) 5.39(\mathrm{tt}, J=3.5,1.6 \mathrm{~Hz}, 2 \mathrm{H}) .{ }^{13} \mathrm{C}$ NMR $\left(\mathrm{CDCl}_{3}, 125 \mathrm{MHz}\right) \delta 14.4\left(\mathrm{CH}_{3}\right), 23.0\left(\mathrm{CH}_{2}\right), 29.1\left(\mathrm{CH}_{2}\right), 29.9\left(\mathrm{CH}_{2}\right), 32.1\left(\mathrm{CH}_{2}\right), 32.9$ $\left(\mathrm{CH}_{2}\right), 130.7(\mathrm{CH})$. GC-MS (EI) $196\left([\mathrm{M}]^{+}, 24 \%\right), 125$ (6\%), 111 (22\%), 97 (51\%), 83 (72\%), $69(100 \%), 55$ (92\%) HRMS (CI+) calcd for $\mathrm{C}_{14} \mathrm{H}_{28}[\mathrm{M}]^{+}:$196.2191, found: 196.2182.

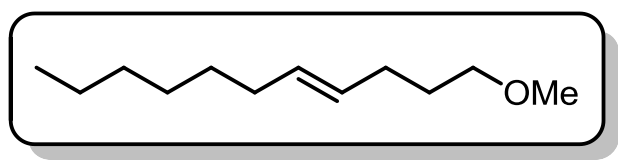

(E)-1-Methoxyundec-4-ene, $3 \mathrm{t}$ (78 $\mathrm{mg}$, 85\%) was prepared according to General Procedure A for photoredox cross-coupling of iodoalkene $\mathbf{2 a}(119 \mathrm{mg}$, $0.5 \mathrm{mmol}$ ) and (3-methoxypropyl)silicate $\mathbf{1 j}$ (252 $\mathrm{mg}$, 0.006 mol, 1.2 equiv). The desired cross-coupled alkene was obtained as a clear, colorless oil. ${ }^{1} \mathbf{H}$ NMR $\left(\mathrm{CDCl}_{3}, 500 \mathrm{MHz}\right) \delta 0.88(\mathrm{t}, J=7.0 \mathrm{~Hz}, 3 \mathrm{H}), 1.21-1.37(\mathrm{~m}, 8 \mathrm{H}), 1.59-1.67(\mathrm{~m}, 2 \mathrm{H})$, $1.97(\mathrm{q}, J=6.8 \mathrm{~Hz}, 2 \mathrm{H}), 2.04(\mathrm{q}, J=6.8 \mathrm{~Hz}, 2 \mathrm{H}), 3.33(\mathrm{~s}, 3 \mathrm{H}), 3.37(\mathrm{t}, J=6.7 \mathrm{~Hz}, 2 \mathrm{H}), 5.30$ $5.48(\mathrm{~m}, 2 \mathrm{H}) .{ }^{13} \mathrm{C} \mathrm{NMR}\left(\mathrm{CDCl}_{3}, 125 \mathrm{MHz}\right) \delta 14.3\left(\mathrm{CH}_{3}\right), 22.9\left(\mathrm{CH}_{2}\right), 29.1\left(\mathrm{CH}_{2}\right), 29.3\left(\mathrm{CH}_{2}\right)$, $29.8\left(\mathrm{CH}_{2}\right), 29.8\left(\mathrm{CH}_{2}\right), 32.0\left(\mathrm{CH}_{2}\right), 32.8\left(\mathrm{CH}_{2}\right), 58.8\left(\mathrm{CH}_{3}\right), 72.5\left(\mathrm{CH}_{2}\right), 129.6(\mathrm{CH}), 131.3$ (CH). GC-MS (EI) $184\left([\mathrm{M}]^{+}, 1 \%\right), 152(31 \%), 110$ (15\%), 95 (30\%), 81 (80\%), 79 (22\%), 71 (36\%), 68 (100\%), 58 (36\%), 55 (36\%). HRMS (CI+) calcd for $\mathrm{C}_{12} \mathrm{H}_{22}\left[\mathrm{M}-\mathrm{H}_{2} \mathrm{O}\right]^{+}: 166.1711$, found: 166.1706 .

\footnotetext{
${ }^{35}$ Collazo, L. R.; Guziec, F. S. J. Org. Chem. 1993, 58, 43.
} 


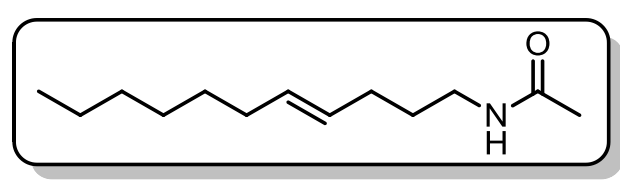

(E)- $\boldsymbol{N}$-(Undec-4-en-1-yl)acetamide, 3u (78 mg, 74\%) was prepared according to General Procedure A for photoredox cross-coupling of iodoalkene $\mathbf{2 a}(119 \mathrm{mg}$, $0.5 \mathrm{mmol})$ and (3-acetamidopropyl)silicate $\mathbf{1 k}(268 \mathrm{mg}$, 0.006 mol, 1.2 equiv) with the following modifications: 1) EtOAc and saturated $\mathrm{Na}_{2} \mathrm{CO}_{3}$ were used in place of $\mathrm{Et}_{2} \mathrm{O}$ and $2 \mathrm{M} \mathrm{NaOH}$ during the extraction. 2) Further purification was accomplished by $\mathrm{SiO}_{2}$ column chromatography (gradient hexane to 50:50 hexane/EtOAc). The desired cross-coupled alkene was obtained as a clear, light brown oil. ${ }^{1} \mathbf{H}$ NMR $\left(\mathrm{CDCl}_{3}, 500\right.$ $\mathrm{MHz}) \delta 0.87(\mathrm{t}, J=6.8 \mathrm{~Hz}, 3 \mathrm{H}), 1.18-1.35(\mathrm{~m}, 8 \mathrm{H}), 1.51-1.59(\mathrm{~m}, 2 \mathrm{H}), 1.90-1.97(\mathrm{~m}, 5 \mathrm{H})$, $2.00(\mathrm{dt}, J=13.8,6.6 \mathrm{~Hz}, 2 \mathrm{H}), 3.22(\mathrm{q}, J=6.6 \mathrm{~Hz}, 2 \mathrm{H}), 5.27-5.48(\mathrm{~m}, 2 \mathrm{H}), 5.74(\mathrm{br} \mathrm{s}, 1 \mathrm{H}) .{ }^{13} \mathrm{C}$ NMR $\left(\mathrm{CDCl}_{3}, 125 \mathrm{MHz}\right) \delta 14.3\left(\mathrm{CH}_{3}\right), 22.8\left(\mathrm{CH}_{3}\right), 23.5\left(\mathrm{CH}_{2}\right), 29.0\left(\mathrm{CH}_{2}\right), 29.6\left(\mathrm{CH}_{2}\right), 29.7$ $\left(\mathrm{CH}_{2}\right), 30.2\left(\mathrm{CH}_{2}\right), 31.9\left(\mathrm{CH}_{2}\right), 32.7\left(\mathrm{CH}_{2}\right), 39.5\left(\mathrm{CH}_{2}\right), 129.1(\mathrm{CH}), 131.7(\mathrm{CH}), 170.2(\mathrm{C}) . \mathrm{GC}-$ MS (EI) $211\left([\mathrm{M}]^{+}, 28 \%\right), 168$ (7\%), $154(7 \%), 140(13 \%), 126(8 \%), 112(9 \%), 110(10 \%), 98$ (20\%), 95 (23\%), 87 (21\%), 85 (10\%), 81 (58\%), 73 (100\%), 68 (40\%), 60 (69\%), 55 (28\%), HRMS (CI+) calcd for $\mathrm{C}_{13} \mathrm{H}_{26} \mathrm{NO}[\mathrm{M}+\mathrm{H}]^{+}: 212.2014$, found: 212.2012.

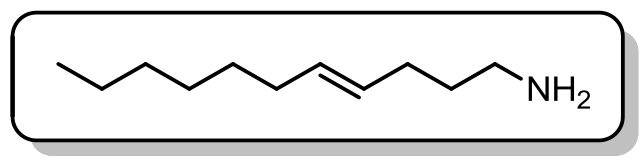

(E)-Undec-4-en-1-amine, 3w (25 mg, 27\%) was prepared according to General Procedure B for photoredox cross-coupling of iodoalkene $\mathbf{2 a}(119 \mathrm{mg}, 0.5$ mmol) and ammonium propylsilicate $\mathbf{1 j}(182 \mathrm{mg}, 0.006$ mol, 1.2 equiv) with the following modifications: 1) EtOAc and saturated $\mathrm{Na}_{2} \mathrm{CO}_{3}$ were used in place of $\mathrm{Et}_{2} \mathrm{O}$ and $2 \mathrm{M} \mathrm{NaOH}$ during the extraction. 2) Saturated $\mathrm{Na}_{2} \mathrm{CO}_{3}$ in deionized $\mathrm{H}_{2} \mathrm{O}$ was used in place of deionized $\mathrm{H}_{2} \mathrm{O}$ at the start of the workup. 3) Further purification was accomplished by $\mathrm{SiO}_{2}$ column chromatography [gradient 99:1 to 90:10 $\mathrm{CH}_{2} \mathrm{Cl}_{2} / \mathrm{MeOH}$ containing $\left.\mathrm{NH}_{4} \mathrm{OH}(1 \%, v / v)\right]$. The desired cross-coupled alkene was obtained as a clear, light brown oil. ${ }^{1} \mathrm{H}$ NMR $\left(\mathrm{CDCl}_{3}, 500 \mathrm{MHz}\right) \delta 0.87(\mathrm{t}, J=6.8 \mathrm{~Hz}, 3 \mathrm{H}), 1.20-1.36(\mathrm{~m}, 9 \mathrm{H}), 1.39$ 1.55 (br. m, 3H), 1.96 (q, $J=6.3 \mathrm{~Hz}, 2 \mathrm{H}), 1.98-2.05(\mathrm{~m}, 2 \mathrm{H}), 2.68(\mathrm{t}, J=6.9 \mathrm{~Hz}, 2 \mathrm{H}), 5.30$ $5.47(\mathrm{~m}, 2 \mathrm{H}) .{ }^{13} \mathrm{C} \mathrm{NMR}\left(\mathrm{CDCl}_{3}, 125 \mathrm{MHz}\right) \delta 14.3\left(\mathrm{CH}_{3}\right), 22.9\left(\mathrm{CH}_{2}\right), 29.1\left(\mathrm{CH}_{2}\right), 29.8\left(\mathrm{CH}_{2}\right)$, $30.1\left(\mathrm{CH}_{2}\right), 32.0\left(\mathrm{CH}_{2}\right), 32.8\left(\mathrm{CH}_{2}\right), 33.8\left(\mathrm{CH}_{2}\right), 42.0\left(\mathrm{CH}_{2}\right), 129.8(\mathrm{CH}), 131.2(\mathrm{CH})$. HRMS (ES+) calcd for $\mathrm{C}_{11} \mathrm{H}_{23} \mathrm{~N}[\mathrm{M}+\mathrm{H}]^{+}: 170.1909$, found: 170.1914. FT-IR $\left(\mathrm{cm}^{-1}\right.$, neat, ATR) 3357 (vw br) 3027 (vw br) 1812 (vs) 2853 (s) 1558 (s br) 1487 (s) 1467 (s) 1251 (m) 965 (s) 740 (s).

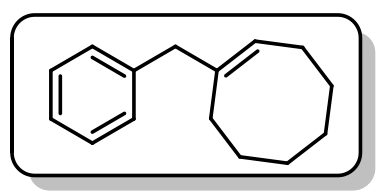

(E)-1-Benzylcyclooct-1-ene, $3 \mathbf{x}(55 \mathrm{mg}, 54 \%)$ was prepared according to General Procedure A for photoredox cross-coupling of bromoalkene $\mathbf{2 g}$ (95 mg, $0.5 \mathrm{mmol}$ ) and benzylsilicate 1e (263 mg, $0.006 \mathrm{~mol}, 1.2$ equiv) with the following modifications: 1) Pentane was used in place of $\mathrm{Et}_{2} \mathrm{O}$ during the extraction. 2) Pentane was used as the eluant for the $\mathrm{SiO}_{2}$ plug. The desired cross-coupled alkene was obtained as a clear, colorless oil. ${ }^{1} \mathbf{H}$ NMR $\left(\mathrm{CDCl}_{3}, 500 \mathrm{MHz}\right) \delta 1.37-1.53(\mathrm{~m}, 8 \mathrm{H}), 2.08-2.15(\mathrm{~m}, 4 \mathrm{H}), 3.30(\mathrm{~s}, 2 \mathrm{H}), 5.39(\mathrm{t}, J=8.2 \mathrm{~Hz}$, $1 \mathrm{H}), 7.17$ - $7.21(\mathrm{~m}, 3 \mathrm{H}), 7.26-7.30(\mathrm{~m}, 2 \mathrm{H}) .{ }^{13} \mathrm{C} \mathrm{NMR}\left(\mathrm{CDCl}_{3}, 125 \mathrm{MHz}\right) \delta 26.6\left(\mathrm{CH}_{2}\right), 26.7$ $\left(\mathrm{CH}_{2}\right), 26.8\left(\mathrm{CH}_{2}\right), 28.8\left(\mathrm{CH}_{2}\right), 28.9\left(\mathrm{CH}_{2}\right), 30.3\left(\mathrm{CH}_{2}\right), 126.1(\mathrm{CH}), 126.2(\mathrm{CH}), 128.4(\mathrm{CH})$, $129.5(\mathrm{CH}), 140.5(\mathrm{C}), 140.8(\mathrm{C}) . \mathrm{GC}-\mathrm{MS}(\mathrm{EI}) 200\left([\mathrm{M}]^{+}, 67 \%\right) 172(63 \%), 143(22 \%), 129$ (52\%), $117(55 \%), 115(35 \%), 109(96 \%), 104(39 \%), 91(100 \%), 81(27 \%), 77(15 \%), 67$ (69\%), 65 (21\%), 55 (13\%), 51 (7\%) HRMS (APCI) calcd for $\mathrm{C}_{15} \mathrm{H}_{21}[\mathrm{M}+\mathrm{H}]^{+}: 201.1643$, found: 201.1637. 


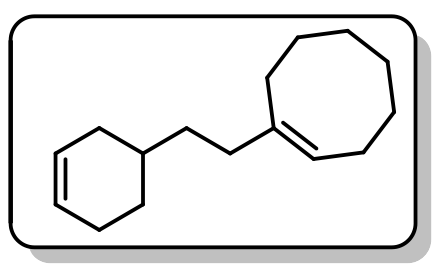

(E)-1-(2-(Cyclohex-3-en-1-yl)ethyl)cyclooct-1-ene, 3y $(98 \mathrm{mg}$ $88 \%$ ) was prepared according to General Procedure A for photoredox cross-coupling of bromoalkene $2 \mathrm{~g}(95 \mathrm{mg}, 0.5 \mathrm{mmol})$ and (2-(3-cyclohexenyl)ethyl)silicate $\mathbf{1 h}(273 \mathrm{mg}, 0.006 \mathrm{~mol}, 1.2$ equiv) with the following modifications: 1) Pentane was used in place of $\mathrm{Et}_{2} \mathrm{O}$ during the extraction. 2) Pentane was used as the eluant for the $\mathrm{SiO}_{2}$ plug. The desired cross-coupled alkene was obtained as a clear, colorless oil. ${ }^{1} \mathrm{H} \mathrm{NMR}\left(\mathrm{CDCl}_{3}, 500 \mathrm{MHz}\right) \delta 1.12$ - $1.42(\mathrm{~m}, 4 \mathrm{H}), 1.41-1.56(\mathrm{~m}, 9 \mathrm{H}), 1.58$ - $1.79(\mathrm{~m}, 2 \mathrm{H})$, 1.95 - $2.17(\mathrm{~m}, 8 \mathrm{H}), 5.33(\mathrm{t}, J=8.2 \mathrm{~Hz}, 1 \mathrm{H}), 5.65(\mathrm{~s}, 2 \mathrm{H}) .{ }^{13} \mathrm{C} \mathrm{NMR}\left(\mathrm{CDCl}_{3}, 125 \mathrm{MHz}\right) \delta 25.6$ $\left(\mathrm{CH}_{2}\right), 26.6\left(\mathrm{CH}_{2}\right), 26.8\left(\mathrm{CH}_{2}\right), 29.2(\mathrm{CH}), 29.2\left(\mathrm{CH}_{2}\right), 29.2\left(\mathrm{CH}_{2}\right), 30.3\left(\mathrm{CH}_{2}\right), 32.2\left(\mathrm{CH}_{2}\right), 33.7$ $\left(\mathrm{CH}_{2}\right), 35.1\left(\mathrm{CH}_{2}\right), 35.5\left(\mathrm{CH}_{2}\right), 123.7(\mathrm{CH}), 127.0(\mathrm{CH}), 127.3(\mathrm{CH}), 141.4(\mathrm{C}) . \mathrm{GC}-\mathrm{MS}(\mathrm{EI})$ $218\left([\mathrm{M}]^{+}, 41 \%\right), 175(11 \%), 147$ (7\%), $137(16 \%), 121$ (12\%), $109(15 \%), 94(58 \%), 91(21 \%)$, 81 (75\%), 79 (100\%), 69 (26\%), 67 (48\%), 55 (27\%), 53 (15\%). HRMS (CI+) calcd for $\mathrm{C}_{16} \mathrm{H}_{26}$ $[\mathrm{M}]^{+}: 218.2035$, found: 218.2030 .

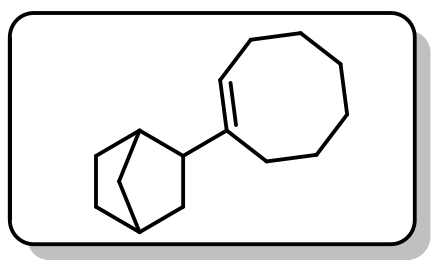

(E)-2-(Cyclooct-1-en-1-yl)bicyclo[2.2.1]heptane, 3z (76 mg, 75\%) was prepared according to General Procedure A for photoredox cross-coupling of bromoalkene $2 \mathrm{~g}(95 \mathrm{mg}, 0.5 \mathrm{mmol})$ and bicycloheptylsilicate $1 \mathrm{~d}$ ( $265 \mathrm{mg}, 0.006 \mathrm{~mol}, 1.2$ equiv) with the following modifications: 1) Pentane was used in place of $\mathrm{Et}_{2} \mathrm{O}$ during the extraction. 2) Pentane was used as the eluant for the $\mathrm{SiO}_{2}$ plug. The desired cross-coupled alkene was obtained as a clear, colorless oil. ${ }^{1} \mathbf{H ~ N M R ~}\left(\mathrm{CDCl}_{3}\right.$, $500 \mathrm{MHz}) \delta 1.01-1.10(\mathrm{~m}, 1 \mathrm{H}), 1.13-1.21(\mathrm{~m}, 2 \mathrm{H}), 1.33-1.38(\mathrm{~m}, 1 \mathrm{H}), 1.40(\mathrm{~d}, J=7.0 \mathrm{~Hz}$, 2H), $1.43-1.56(\mathrm{~m}, 10 \mathrm{H}), 1.99(\mathrm{t}, J=7.2 \mathrm{~Hz}, 1 \mathrm{H}), 2.06-2.23(\mathrm{~m}, 6 \mathrm{H}), 5.28(\mathrm{td}, J=8.1,1.2 \mathrm{~Hz}$, $1 \mathrm{H}) .{ }^{13} \mathrm{C} \mathrm{NMR}\left(\mathrm{CDCl}_{3}, 125 \mathrm{MHz}\right) \delta 26.5\left(\mathrm{CH}_{2}\right), 26.7\left(\mathrm{CH}_{2}\right), 26.9\left(\mathrm{CH}_{2}\right), 29.2\left(\mathrm{CH}_{2}\right), 29.4$ $\left(\mathrm{CH}_{2}\right), 29.7\left(\mathrm{CH}_{2}\right), 30.3\left(\mathrm{CH}_{2}\right), 30.8\left(\mathrm{CH}_{2}\right), 36.1\left(\mathrm{CH}_{2}\right), 36.8\left(\mathrm{CH}_{2}\right), 36.9(\mathrm{CH}), 40.3(\mathrm{CH}), 48.2$ (CH), $120.7(\mathrm{CH}), 144.7$ (C). GC-MS (EI) $204\left([\mathrm{M}]^{+}, 39 \%\right), 176(29 \%), 161$ (15\%), 147 (15\%), 121 (32\%), 108 (17\%), 95 (42\%), 93 (34\%), 91 (33\%), 80 (100\%), 77 (22\%), 67 (51\%) 55 (16\%). HRMS (CI+) calcd for $\mathrm{C}_{15} \mathrm{H}_{24}[\mathrm{M}]^{+}: 204.1878$, found: 204.1873 .

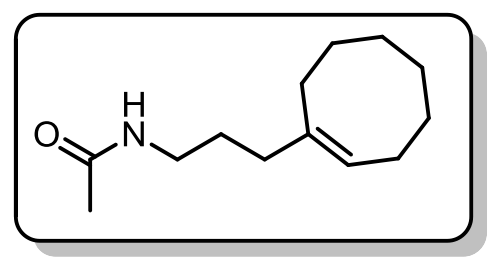

(E)-N-(3-(Cyclooct-1-en-1-yl)propyl)acetamide, 3aa (99 mg, 94\%) was prepared according to General Procedure A for photoredox cross-coupling of bromoalkene $2 \mathrm{~g}$ (95 $\mathrm{mg}, 0.5 \mathrm{mmol})$ and (3-acetamidopropyl)silicate $\mathbf{1 k}$ (268 $\mathrm{mg}, 0.006 \mathrm{~mol}, 1.2$ equiv) with the following modifications: 1) EtOAc and saturated $\mathrm{Na}_{2} \mathrm{CO}_{3}$ were used in place of $\mathrm{Et}_{2} \mathrm{O}$ and $2 \mathrm{M} \mathrm{NaOH}$ during the extraction. 2) Further purification was accomplished by $\mathrm{SiO}_{2}$ column chromatography (gradient hexane to 50:50 hexane/EtOAc). The desired cross-coupled alkene was obtained as a clear, pale yellow oil. ${ }^{1} \mathrm{H}$ NMR $\left(\mathrm{CDCl}_{3}, 500 \mathrm{MHz}\right) \delta 1.37$ - $1.52(\mathrm{~m}, 8 \mathrm{H}), 1.55$ - $1.63(\mathrm{~m}, 2 \mathrm{H}), 1.94(\mathrm{~s}, 3 \mathrm{H})$, $1.98(\mathrm{t}, J=7.9 \mathrm{~Hz}, 2 \mathrm{H}), 2.02-2.08(\mathrm{~m}, 2 \mathrm{H}), 2.08-2.15(\mathrm{~m}, 2 \mathrm{H}), 3.21(\mathrm{q}, J=6.8 \mathrm{~Hz}, 2 \mathrm{H}), 5.32$ $(\mathrm{t}, J=8.1 \mathrm{~Hz}, 1 \mathrm{H}), 5.75($ br s, $1 \mathrm{H}) .{ }^{13} \mathrm{C} \mathrm{NMR}\left(\mathrm{CDCl}_{3}, 125 \mathrm{MHz}\right) \delta 23.5\left(\mathrm{CH}_{3}\right), 26.4\left(\mathrm{CH}_{2}\right), 26.5$ $\left(\mathrm{CH}_{2}\right), 26.7\left(\mathrm{CH}_{2}\right), 28.1\left(\mathrm{CH}_{2}\right), 28.9\left(\mathrm{CH}_{2}\right), 29.0\left(\mathrm{CH}_{2}\right), 30.1\left(\mathrm{CH}_{2}\right), 34.9\left(\mathrm{CH}_{2}\right), 39.8\left(\mathrm{CH}_{2}\right)$, $124.6(\mathrm{CH}), 140.0(\mathrm{C}), 170.2$ (C). GC-MS (EI) 209 ([M] $\left.{ }^{+}, 8 \%\right), 150(100 \%), 135(34 \%), 122$ (68\%), 109 (21\%), 107 (20\%), 95 (27\%), 93 (29\%), 86 (15\%), 81 (31\%), 79 (32\%), 73 (36\%), 67 (33\%), $60(22 \%), 55(15 \%)$. HRMS (ES+) calcd for $\mathrm{C}_{13} \mathrm{H}_{24} \mathrm{NO}[\mathrm{M}+\mathrm{H}]^{+}: 210.1858$, found: 210.1857. 


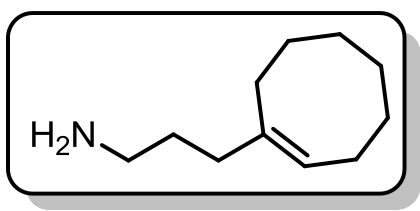

(E)-3-(Cyclooct-1-en-1-yl)propan-1-amine, 3ab (84 mg, 25\%) was prepared according to General Procedure B for photoredox crosscoupling of bromoalkene $2 \mathrm{~g}$ (95 $\mathrm{mg}, 0.5 \mathrm{mmol}$ ) and ammonium propylsilicate $1 \mathbf{j}$ (182 $\mathrm{mg}, 0.006 \mathrm{~mol}, 1.2$ equiv) with the following modifications: 1) EtOAc and saturated aq $\mathrm{Na}_{2} \mathrm{CO}_{3}$ were used in place of $\mathrm{Et}_{2} \mathrm{O}$ and $2 \mathrm{M} \mathrm{NaOH}$ during the extraction. 2) Saturated aq $\mathrm{Na}_{2} \mathrm{CO}_{3}$ was used in place of deionized $\mathrm{H}_{2} \mathrm{O}$ at the start of the workup. 3) Further purification was accomplished by $\mathrm{SiO}_{2}$ column chromatography (gradient 99:1 to 90:10 $\mathrm{CH}_{2} \mathrm{Cl}_{2} / \mathrm{MeOH}$ containing $\mathrm{NH}_{4} \mathrm{OH}(1 \%, v / v)$. The desired cross-coupled alkene was obtained as a clear, light brown oil. ${ }^{1} \mathbf{H} \mathbf{~ N M R}\left(\mathrm{CDCl}_{3}, 500\right.$ MHz) $\delta 1.41$ - $1.56(\mathrm{~m}, 9 \mathrm{H}), 1.56-1.67$ (m, 2H), 1.99 - 2.05 (m, 2H), 2.04 - 2.12 (m, 3H), 2.12 $2.23(\mathrm{~m}, 2 \mathrm{H}), 2.50$ (br s, $1 \mathrm{H}), 2.68-2.82(\mathrm{~m}, 1 \mathrm{H}), 5.35(\mathrm{t}, J=7.8 \mathrm{~Hz}, 1 \mathrm{H}) .{ }^{13} \mathrm{C} \mathrm{NMR}\left(\mathrm{CDCl}_{3}\right.$, $125 \mathrm{MHz}) \delta 26.5\left(\mathrm{CH}_{2}\right), 26.8\left(\mathrm{CH}_{2}\right), 29.1\left(\mathrm{CH}_{2}\right), 29.2\left(\mathrm{CH}_{2}\right), 30.2\left(\mathrm{CH}_{2}\right), 31.7\left(\mathrm{CH}_{2}\right), 34.9$ $\left(\mathrm{CH}_{2}\right), 38.8\left(\mathrm{CH}_{2}\right), 42.1\left(\mathrm{CH}_{2}\right), 124.3(\mathrm{CH}), 140.4(\mathrm{C})$. HRMS (ES+) calcd for $\mathrm{C}_{11} \mathrm{H}_{21} \mathrm{~N}[\mathrm{M}+\mathrm{H}]^{+}$: 168.1752, found:168.1754. FT-IR (cm ${ }^{-1}$, neat, ATR) 3303 (w, br) 3036 (vw) 2919 (vs) 2848 (s) 1573 (s) 1467 (s), 1304 (s) 818 (w).

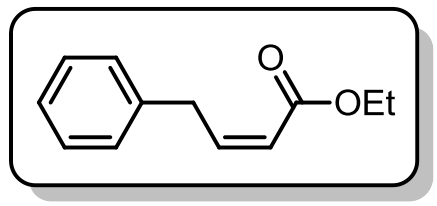

(Z)-Ethyl 4-Phenylbut-2-enoate, ${ }^{\mathbf{3 6}}$ 3ac (91 mg, 90\%) was prepared according to General Procedure A for photoredox cross-coupling of bromoalkene $2 \mathbf{f}(90 \mathrm{mg}, 0.5 \mathrm{mmol})$ and benzylsilicate $1 \mathbf{1 d}(263 \mathrm{mg}$, 0.006 mol, 1.2 equiv). The desired cross-coupled alkene was obtained as a clear, yellow oil. ${ }^{1} \mathbf{H}$ NMR $\left(\mathrm{CDCl}_{3}, 500 \mathrm{MHz}\right) \delta 1.32$ $(\mathrm{t}, J=7.0 \mathrm{~Hz}, 3 \mathrm{H}), 4.03(\mathrm{dd}, J=7.6,1.5 \mathrm{~Hz}, 2 \mathrm{H}), 4.22(\mathrm{q}, J=7.6 \mathrm{~Hz}, 2 \mathrm{H}), 5.85(\mathrm{dt}, J=11.3,1.5$ $\mathrm{Hz}, 1 \mathrm{H}), 6.35(\mathrm{dt}, J=11.3,7.6 \mathrm{~Hz}, 1 \mathrm{H}), 7.21-7.25(\mathrm{~m}, 3 \mathrm{H}), 7.30(\mathrm{t}, J=7.3 \mathrm{~Hz}, 2 \mathrm{H}) .{ }^{13} \mathrm{C} \mathrm{NMR}$ $\left(\mathrm{CDCl}_{3}, 125 \mathrm{MHz}\right) \delta 14.5\left(\mathrm{CH}_{3}\right), 35.4\left(\mathrm{CH}_{2}\right), 60.3\left(\mathrm{CH}_{2}\right), 120.2(\mathrm{CH}), 126.6(\mathrm{CH}), 128.8(\mathrm{CH})$, 139.7 (C), $148.2(\mathrm{CH}), 166.7$ (C). GC-MS (EI) $190\left([\mathrm{M}]^{+}, 76 \%\right), 162(14 \%), 144(55 \%), 133$ (38\%), $127(16 \%), 117(72 \%), 115$ (100\%), $105(11 \%), 91(40 \%), 89(12 \%), 77(10 \%), 65$ (19\%), $58(8 \%), 51(9 \%)$. HRMS (ES+) calcd for $\mathrm{C}_{12} \mathrm{H}_{14} \mathrm{O}_{2} \mathrm{Na}[\mathrm{M}+\mathrm{Na}]^{+}: 213.0891$, found: 213.0896 .

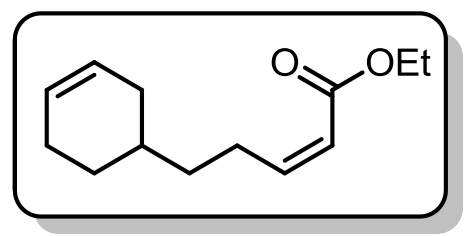

(Z)-Ethyl 5-(Cyclohex-3-en-1-yl)pent-2-enoate, 3ad (98 mg, 93\%) was prepared according to General Procedure A for photoredox cross-coupling of bromoalkene $2 \mathbf{f}(90 \mathrm{mg}, 0.5 \mathrm{mmol})$ and (2-(3-cyclohexenyl)ethyl)silicate $\mathbf{1 h}$ (273 $\mathrm{mg}, 0.006 \mathrm{~mol}, 1.2$ equiv). The desired cross-coupled alkene was obtained as a clear, colorless oil. ${ }^{1} \mathrm{H}$ NMR $\left(\mathrm{CDCl}_{3}, 500 \mathrm{MHz}\right) \delta 1.19-1.34(\mathrm{~m}, 1 \mathrm{H})$, $1.30(\mathrm{t}, J=6.8 \mathrm{~Hz}, 3 \mathrm{H}), 1.39-1.46(\mathrm{~m}, 2 \mathrm{H}), 1.54-1.62(\mathrm{~m}, 1 \mathrm{H}), 1.64-1.73(\mathrm{~m}, 1 \mathrm{H}), 1.74-1.82$ $(\mathrm{m}, 1 \mathrm{H}), 2.01-2.09(\mathrm{~m}, 2 \mathrm{H}), 2.10-2.17(\mathrm{~m}, 1 \mathrm{H}), 2.71(\mathrm{qt}, J=7.7,1.7 \mathrm{~Hz}, 2 \mathrm{H}), 4.18(\mathrm{q}, J=7.1$ $\mathrm{Hz}, 2 \mathrm{H}), 5.66(\mathrm{~s}, 2 \mathrm{H}), 5.76(\mathrm{dt}, J=11.5,1.6 \mathrm{~Hz}, 1 \mathrm{H}), 6.23(\mathrm{dt}, J=11.5,7.5 \mathrm{~Hz}, 1 \mathrm{H}) .{ }^{13} \mathrm{C} \mathrm{NMR}$ $\left(\mathrm{CDCl}_{3}, 125 \mathrm{MHz}\right) \delta 14.5\left(\mathrm{CH}_{3}\right), 25.4\left(\mathrm{CH}_{2}\right), 26.8\left(\mathrm{CH}_{2}\right), 29.0(\mathrm{CH}), 31.9\left(\mathrm{CH}_{2}\right), 33.5\left(\mathrm{CH}_{2}\right)$, $36.1\left(\mathrm{CH}_{2}\right), 60.0\left(\mathrm{CH}_{2}\right), 119.9(\mathrm{CH}), 126.7(\mathrm{CH}), 127.3(\mathrm{CH}), 150.9(\mathrm{CH}), 166.7(\mathrm{C})$. GC-MS (EI) $208\left([\mathrm{M}]^{+}, 7 \%\right), 162$ (26\%), 144 (13\%), 134 (61\%), 127 (61\%), 120 (85\%), 114 (51\%), 105 (16\%), 101 (40\%), 99 (79\%), 93 (47\%), 91 (53\%), 86 (48\%), $81(61 \%), 79$ (100\%), 73 (21\%), 67

\footnotetext{
${ }^{36}$ Ghosh, A. K.; Nicponski, D. R. Org. Lett. 2011, 13, 4328.
} 
(53\%) 55 (32\%), 53 (37\%). HRMS (ES+) calcd for $\mathrm{C}_{13} \mathrm{H}_{21} \mathrm{O}_{2}[\mathrm{M}+\mathrm{H}]^{+}: 209.1542$, found: 209.1545 .

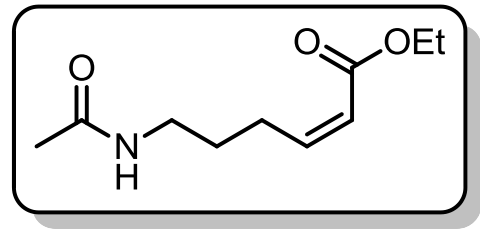

(Z)-Ethyl 6-Acetamidohex-2-enoate, 3af (63 $\mathrm{mg}$, 63\%) was prepared according to General Procedure A for photoredox crosscoupling of bromoalkene $2 \mathbf{f}(90 \mathrm{mg}, 0.5 \mathrm{mmol})$ and 3acetamidopropyl)silicate 1k (268 $\mathrm{mg}, 0.006 \mathrm{~mol}, 1.2$ equiv) with the following modifications: 1) EtOAc and saturated $\mathrm{Na}_{2} \mathrm{CO}_{3}$ were used in place of $\mathrm{Et}_{2} \mathrm{O}$ and $2 \mathrm{M} \mathrm{NaOH}$ during the extraction.

2) Further purification was accomplished by $\mathrm{SiO}_{2}$ column chromatography (gradient hexane to 40:60 hexane/EtOAc). The desired cross-coupled alkene was obtained as a clear, yellow oil. ${ }^{1} \mathbf{H}$ NMR $\left(\mathrm{CDCl}_{3}, 500 \mathrm{MHz}\right) \delta 1.26(\mathrm{t}, J=7.1 \mathrm{~Hz}, 3 \mathrm{H}), 1.59-1.67(\mathrm{~m}, 2 \mathrm{H}), 1.94(\mathrm{~s}, 3 \mathrm{H}), 2.64(\mathrm{q}, J$ $=7.3 \mathrm{~Hz}, 2 \mathrm{H}), 3.20(\mathrm{q}, J=6.2 \mathrm{~Hz}, 2 \mathrm{H}), 4.14(\mathrm{q}, J=7.1 \mathrm{~Hz}, 2 \mathrm{H}), 5.81(\mathrm{dt}, J=11.3,1.2 \mathrm{~Hz}, 1 \mathrm{H})$, $6.17(\mathrm{dt}, J=11.5,8.2 \mathrm{~Hz}, 1 \mathrm{H}), 6.37(\mathrm{br} \mathrm{s}, 1 \mathrm{H}) .{ }^{13} \mathrm{C} \mathrm{NMR}\left(\mathrm{CDCl}_{3}, 125 \mathrm{MHz}\right) \delta 14.4\left(\mathrm{CH}_{3}\right), 23.5$ $\left(\mathrm{CH}_{3}\right), 26.0\left(\mathrm{CH}_{2}\right), 28.3\left(\mathrm{CH}_{2}\right), 38.3\left(\mathrm{CH}_{2}\right), 60.2\left(\mathrm{CH}_{2}\right), 121.1(\mathrm{CH}), 149.0(\mathrm{CH}), 167.0(\mathrm{C})$, 170.4 (C). GC-MS (EI) 199 ([M] $\left.]^{+}, 1 \%\right), 156$ (79\%), 125 (30\%), 112 (100\%), 100 (24\%), 94 (42\%), 86 (64\%), 82 (21\%), 72 (28\%), 67 (31\%), 60 (21\%), 55 (12\%). 53 (10\%). HRMS (ES+) calcd for $\mathrm{C}_{10} \mathrm{H}_{18} \mathrm{NO}_{3}[\mathrm{M}+\mathrm{H}]^{+}: 200.1287$, found: 200.1288 .

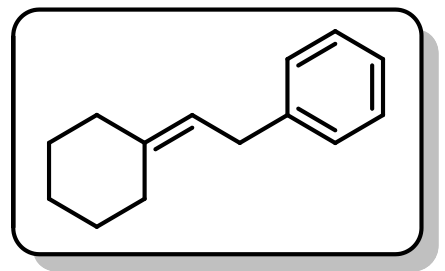

(2-Cyclohexylideneethyl)benzene, ${ }^{37}$ 3ah $(57 \mathrm{mg}, 60 \%)$ was prepared according to General Procedure A for photoredox crosscoupling of bromoalkene $\mathbf{2 h}(88 \mathrm{mg}, 0.5 \mathrm{mmol})$ and benzylsilicate $1 \mathrm{e}(263 \mathrm{mg}, 0.006 \mathrm{~mol}, 1.2$ equiv) with the following modifications: 1) Pentane was used in place of $\mathrm{Et}_{2} \mathrm{O}$ during the extraction. 2) Pentane was used as the eluant for the $\mathrm{SiO}_{2}$ plug. The desired cross-coupled alkene was obtained as a clear, colorless oil.

${ }^{1} \mathrm{H} \mathrm{NMR}\left(\mathrm{CDCl}_{3}, 500 \mathrm{MHz}\right) \delta 1.54-1.63(\mathrm{~m}, 6 \mathrm{H}), 2.11-2.17(\mathrm{~m}, 2 \mathrm{H}), 2.27(\mathrm{t}, J=5.2 \mathrm{~Hz}, 2 \mathrm{H})$, $3.38(\mathrm{~d}, J=7.3 \mathrm{~Hz}, 2 \mathrm{H}), 5.29$ (tt, $J=7.4,1.1 \mathrm{~Hz}, 1 \mathrm{H}), 7.16-7.22(\mathrm{~m}, 3 \mathrm{H}), 7.27-7.32(\mathrm{~m}, 2 \mathrm{H})$. ${ }^{13} \mathrm{C} \mathrm{NMR}\left(\mathrm{CDCl}_{3}, 125 \mathrm{MHz}\right) \delta 27.2\left(\mathrm{CH}_{2}\right), 28.1\left(\mathrm{CH}_{2}\right), 28.9\left(\mathrm{CH}_{2}\right), 29.0\left(\mathrm{CH}_{2}\right), 33.6\left(\mathrm{CH}_{2}\right)$, $37.4\left(\mathrm{CH}_{2}\right), 120.0(\mathrm{CH}), 125.9(\mathrm{CH}), 128.6(\mathrm{CH}), 128.6(\mathrm{CH}), 140.8(\mathrm{C}), 142.2(\mathrm{C}) . \mathrm{GC}-\mathrm{MS}(\mathrm{EI})$ $186\left([\mathrm{M}]^{+}, 57 \%\right), 143(13 \%), 129(28 \%), 117(13 \%), 115(15 \%), 104(100 \%), 95$ (17\%), 91 (32\%), 79 (10\%), 67 (11\%), 55 (3\%), 51 (4\%). HRMS (APCI) calcd for $\mathrm{C}_{14} \mathrm{H}_{19}[\mathrm{M}+\mathrm{H}]^{+}$: 187.1487, found: 187.1481 .

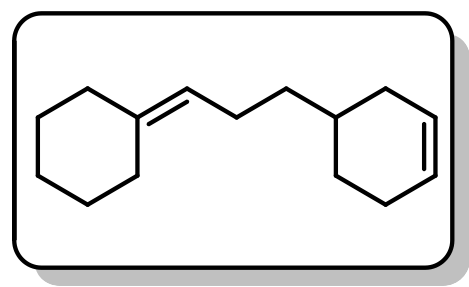

4-(3-Cyclohexylidenepropyl)cyclohex-1-ene, 3ai (80 mg, 78\%) was prepared according to General Procedure A for photoredox cross-coupling of bromoalkene $2 \mathbf{h}(88 \mathrm{mg}, 0.5 \mathrm{mmol})$ and (2-(3cyclohexenyl)ethyl)silicate $\mathbf{1 h}$ (273 $\mathrm{mg}, 0.006 \mathrm{~mol}, 1.2$ equiv) with the following modifications: 1) Pentane was used in place of $\mathrm{Et}_{2} \mathrm{O}$ during the extraction. 2) Pentane was used as the eluant for the $\mathrm{SiO}_{2}$ plug. The desired cross-coupled alkene was obtained as a clear, colorless oil. ${ }^{1} \mathrm{H}$ NMR $\left(\mathrm{CDCl}_{3}, 500 \mathrm{MHz}\right) \delta 1.17-1.33(\mathrm{~m}, 4 \mathrm{H}), 1.46-1.58(\mathrm{~m}, 7 \mathrm{H}), 1.59$ - 1.69 (m, 1H), 1.70 - 1.78 (m, 1H), 1.98 - 2.09 (m, 6H), 2.09 - 2.14 (m, 2H), 5.06 (t, J = 7.2 Hz,

\footnotetext{
${ }^{37}$ Perez-Aguilar, M. C.; Valdes, C. Angew. Chem., Int. Ed. 2012, 51, 5953.
} 
1H), 5.61 - $5.69(\mathrm{~m}, 2 \mathrm{H}) .{ }^{13} \mathrm{C}$ NMR $\left(\mathrm{CDCl}_{3}, 125 \mathrm{MHz}\right) \delta 24.6\left(\mathrm{CH}_{2}\right), 25.6\left(\mathrm{CH}_{2}\right), 27.2\left(\mathrm{CH}_{2}\right)$, $28.1\left(\mathrm{CH}_{2}\right), 28.9\left(\mathrm{CH}_{2}\right), 29.0(\mathrm{CH}), 29.1\left(\mathrm{CH}_{2}\right), 32.2\left(\mathrm{CH}_{2}\right), 33.3\left(\mathrm{CH}_{2}\right), 37.4\left(\mathrm{CH}_{2}\right), 37.5\left(\mathrm{CH}_{2}\right)$, $121.7(\mathrm{CH}), 127.0(\mathrm{CH}), 127.3(\mathrm{CH}), 139.7(\mathrm{CH}) . \mathrm{GC}-\mathrm{MS}(\mathrm{EI}) 204\left([\mathrm{M}]^{+}, 40 \%\right), 161(10 \%)$, 148 (6\%), 135 (5\%), 121 (21\%), 108 (21\%), 94 (53\%), 91 (16\%), 79 (100\%), 67 (58\%), 65 (9\%), 55 (24\%), 53 (14\%). HRMS (CI+) calcd for $\mathrm{C}_{15} \mathrm{H}_{24}[\mathrm{M}]^{+}:$204.1878, found: 204.1870.

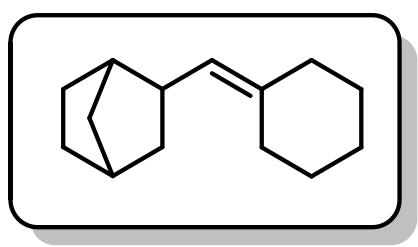

2-(Cyclohexylidenemethyl)bicyclo[2.2.1]heptane, 3aj (85 mg, $90 \%$ ) was prepared according to General Procedure A for photoredox cross-coupling of bromoalkene $2 \mathbf{h}(88 \mathrm{mg}, 0.5 \mathrm{mmol})$ and bicycloheptylsilicate $1 \mathrm{~d}$ ( $265 \mathrm{mg}, 0.006 \mathrm{~mol}, 1.2$ equiv) with the following modifications: 1) Pentane was used in place of $\mathrm{Et}_{2} \mathrm{O}$ during the extraction. 2) Pentane was used as the eluant for the $\mathrm{SiO}_{2}$ plug. The desired cross-coupled alkene was obtained as a clear, colorless oil. ${ }^{1} \mathbf{H} \mathbf{~ N M R}\left(\mathrm{CDCl}_{3}\right.$, $500 \mathrm{MHz}) \delta 1.06-1.24(\mathrm{~m}, 4 \mathrm{H}), 1.33-1.41(\mathrm{~m}, 1 \mathrm{H}), 1.44-1.57(\mathrm{~m}, 9 \mathrm{H}), 1.91(\mathrm{br} \mathrm{s}, 1 \mathrm{H}), 2.02(\mathrm{t}$, $J=5.3 \mathrm{~Hz}, 2 \mathrm{H}), 2.12(\mathrm{t}, J=5.9 \mathrm{~Hz}, 2 \mathrm{H}), 2.18-2.28(\mathrm{~m}, 2 \mathrm{H}), 4.96(\mathrm{~d}, J=8.5 \mathrm{~Hz}, 1 \mathrm{H}) .{ }^{13} \mathrm{C} \mathrm{NMR}$ $\left(\mathrm{CDCl}_{3}, 125 \mathrm{MHz}\right) \delta 27.2\left(\mathrm{CH}_{2}\right), 28.1\left(\mathrm{CH}_{2}\right), 29.0\left(\mathrm{CH}_{2}\right), 29.3\left(\mathrm{CH}_{2}\right), 29.5\left(\mathrm{CH}_{2}\right), 30.0\left(\mathrm{CH}_{2}\right)$, $36.2\left(\mathrm{CH}_{2}\right), 36.8\left(\mathrm{CH}_{2}\right), 37.3\left(\mathrm{CH}_{2}\right), 39.9(\mathrm{CH}), 40.2(\mathrm{CH}), 43.8(\mathrm{CH}), 129.1(\mathrm{CH}), 137.8(\mathrm{C})$. GC-MS (EI) 190 ([M] $\left.]^{+}, 56 \%\right), 161$ (12\%), 149 (10\%), 147 (19\%), 134 (7\%), $122(20 \%), 107$ (30\%), 105 (12\%), 95 (25\%), 93 (52\%), 91 (34\%), 80 (100\%), 77 (26\%), 67 (55\%), 55 (16\%) 53 (13\%). HRMS (CI+) calcd for $\mathrm{C}_{14} \mathrm{H}_{22}[\mathrm{M}]^{+}:$190.1722, found: 190.1716 .

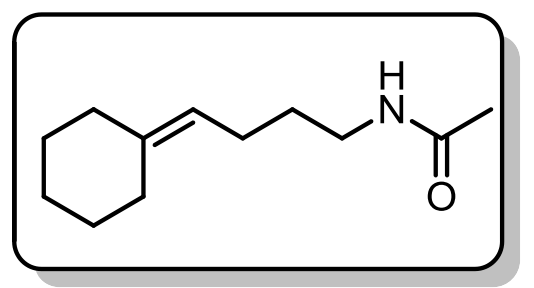

N-(4-Cyclohexylidenebutyl)acetamide, 3ak (77 mg, 78\%) was prepared according to General Procedure A for photoredox cross-coupling of bromoalkene $\mathbf{2 h}(88 \mathrm{mg}, 0.5$ mmol) and 3-(acetamidopropyl)silicate $\mathbf{1 k}$ (268 $\mathrm{mg}, 0.006$ mol, 1.2 equiv) with the following modifications: 1) EtOAc and saturated $\mathrm{Na}_{2} \mathrm{CO}_{3}$ were used in place of $\mathrm{Et}_{2} \mathrm{O}$ and $2 \mathrm{M}$ $\mathrm{NaOH}$ during the extraction. 2) Further purification was accomplished by $\mathrm{SiO}_{2}$ column chromatography (gradient hexane to 50:50 hexane/EtOAc). The desired cross-coupled alkene was obtained as a clear, colorless oil. ${ }^{1} \mathbf{H}$ NMR $\left(\mathrm{CDCl}_{3}, 500\right.$ $\mathrm{MHz}) \delta 1.43-1.59(\mathrm{~m}, 8 \mathrm{H}), 1.95(\mathrm{~s}, 3 \mathrm{H}), 1.98-2.07(\mathrm{~m}, 4 \mathrm{H}), 2.07-2.12(\mathrm{~m}, 2 \mathrm{H}), 3.21(\mathrm{q}, J=$ $6.6 \mathrm{~Hz}, 2 \mathrm{H}), 5.03(\mathrm{t}, J=7.2 \mathrm{~Hz}, 1 \mathrm{H}), 5.76(\mathrm{br} \mathrm{s}, 1 \mathrm{H}) .{ }^{13} \mathrm{C} \mathrm{NMR}\left(\mathrm{CDCl}_{3}, 125 \mathrm{MHz}\right) \delta 23.5$ $\left(\mathrm{CH}_{3}\right), 24.7\left(\mathrm{CH}_{2}\right), 27.1\left(\mathrm{CH}_{2}\right), 28.0\left(\mathrm{CH}_{2}\right), 28.8\left(\mathrm{CH}_{2}\right), 28.9\left(\mathrm{CH}_{2}\right), 30.1\left(\mathrm{CH}_{2}\right), 37.3\left(\mathrm{CH}_{2}\right), 39.6$ $\left(\mathrm{CH}_{2}\right), 120.3(\mathrm{CH}), 140.7(\mathrm{C}), 170.2(\mathrm{C})$. GC-MS (EI) $195\left([\mathrm{M}]^{+}, 84 \%\right), 152(12 \%), 136(80 \%)$, 121 (33\%), 107 (53\%), 100 (32\%), 93 (40\%), 91 (19\%), 86 (38\%), 81 (54\%), 79 (58\%), 73 (100\%), 67 (60\%), 60 (48\%), 55 (23\%). HRMS (ES+) calcd for $\mathrm{C}_{12} \mathrm{H}_{22} \mathrm{NO}[\mathrm{M}+\mathrm{H}]^{+}: 196.1701$, found: 196.1703 .

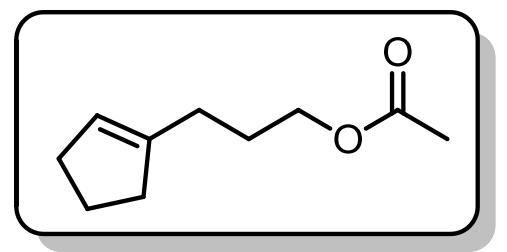

3-(Cyclopent-1-en-1-yl)propyl Acetate, 3am (42 mg, 50\%) was prepared according to General Procedure A for photoredox cross-coupling of chloroalkene $2 \mathrm{l}(51 \mathrm{mg}, 0.5 \mathrm{mmol})$ and (3acetoxypropylsilicate $1 \mathbf{1 a}(273 \mathrm{mg}, 0.006 \mathrm{~mol}, 1.2$ equiv). The desired cross-coupled alkene was obtained as a clear, colorless oil. ${ }^{1} \mathrm{H}$ NMR $\left(\mathrm{CDCl}_{3}, 500 \mathrm{MHz}\right) \delta 1.75-1.83(\mathrm{~m}, 2 \mathrm{H}), 1.82-$ $1.90(\mathrm{~m}, 2 \mathrm{H}), 2.05(\mathrm{~s}, 3 \mathrm{H}), 2.13(\mathrm{t}, J=7.4 \mathrm{~Hz}, 2 \mathrm{H}), 2.23(\mathrm{t}, J=7.2 \mathrm{~Hz}, 2 \mathrm{H}), 2.27-2.33(\mathrm{~m}, 2 \mathrm{H})$, $4.06(\mathrm{t}, J=6.7 \mathrm{~Hz}, 2 \mathrm{H}), 5.31-5.39(\mathrm{~m}, 1 \mathrm{H}) .{ }^{13} \mathrm{C} \mathrm{NMR}\left(\mathrm{CDCl}_{3}, 125 \mathrm{MHz}\right) \delta 21.2\left(\mathrm{CH}_{3}\right), 23.7$ 
$\left(\mathrm{CH}_{2}\right), 27.0\left(\mathrm{CH}_{2}\right), 27.7\left(\mathrm{CH}_{2}\right), 32.7\left(\mathrm{CH}_{2}\right), 35.3\left(\mathrm{CH}_{2}\right), 64.6\left(\mathrm{CH}_{2}\right), 124.2(\mathrm{CH}), 143.7(\mathrm{C}), 171.4$ (C). GC-MS (EI) 168 ([M] $\left.{ }^{+}, 0.1 \%\right), 108$ (52\%), 93 (100\%), 91 (19\%), 79 (57\%), 77 (18\%), 67 (36\%) 53 (6\%). HRMS (CI+) calcd for $\mathrm{C}_{10} \mathrm{H}_{17} \mathrm{O}_{2}[\mathrm{M}+\mathrm{H}]^{+}:$: 169.1229, found: 169.1228.

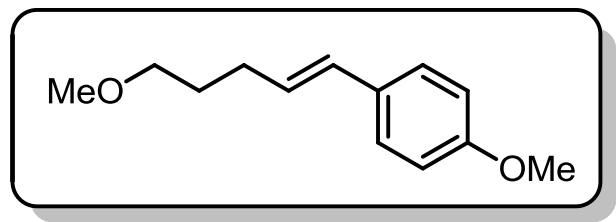

(E)-1-Methoxy-4-(5-methoxypent-1-en-1-yl)benzene, 3an $(79 \mathrm{mg}, 77 \%)$ was prepared according to General Procedure A for photoredox cross-coupling of chloroalkene $\quad \mathbf{2 m} \quad(84 \quad \mathrm{mg}, \quad 0.5 \quad \mathrm{mmol})$ and (3methoxypropyl)silicate $\mathbf{1 j}$ ( $252 \mathrm{mg}, 0.006 \mathrm{~mol}, 1.2$ equiv). The desired cross-coupled alkene was obtained as a clear, colorless oil. ${ }^{1} \mathrm{H}$ NMR $\left(\mathrm{CDCl}_{3}, 500 \mathrm{MHz}\right) \delta 1.70-1.78(\mathrm{~m}, 2 \mathrm{H}), 2.26(\mathrm{q}, J=7.3 \mathrm{~Hz}, 2 \mathrm{H}), 3.35$ $(\mathrm{s}, 3 \mathrm{H}), 3.42(\mathrm{t}, J=6.6 \mathrm{~Hz}, 2 \mathrm{H}), 3.80(\mathrm{~s}, 3 \mathrm{H}), 6.07(\mathrm{dt}, J=15.7,7.0 \mathrm{~Hz}, 1 \mathrm{H}), 6.35(\mathrm{~d}, J=15.6$ $\mathrm{Hz}, 1 \mathrm{H}), 6.84(\mathrm{~d}, J=8.8 \mathrm{~Hz}, 2 \mathrm{H}), 7.27(\mathrm{~d}, J=8.5 \mathrm{~Hz}, 2 \mathrm{H}) .{ }^{13} \mathrm{C} \mathrm{NMR}\left(\mathrm{CDCl}_{3}, 125 \mathrm{MHz}\right) \delta 29.7$ $\left(\mathrm{CH}_{2}\right), 29.7\left(\mathrm{CH}_{2}\right), 55.5\left(\mathrm{CH}_{3}\right), 58.8\left(\mathrm{CH}_{3}\right), 72.4\left(\mathrm{CH}_{2}\right), 114.2(\mathrm{CH}), 127.2(\mathrm{CH}), 128.2(\mathrm{CH})$, $129.8(\mathrm{CH}), 130.8(\mathrm{C}), 159.0(\mathrm{C})$. GC-MS (EI) $206\left([\mathrm{M}]^{+}, 100 \%\right), 174$ (75\%), 159 (62\%), 147 (85\%), 143 (50\%), 134 (15\%), 131 (26\%), 128 (19\%), 121 (44\%) 117 (20\%), $115(43 \%), 103$ (20\%), 91 (48\%), 77 (17\%), $71(10 \%), 65(8 \%) 51$ (6\%). HRMS (ES+) calcd for $\mathrm{C}_{13} \mathrm{H}_{19} \mathrm{O}_{2}$ $[\mathrm{M}+\mathrm{H}]^{+}:$207.1388, found: 207.1385.

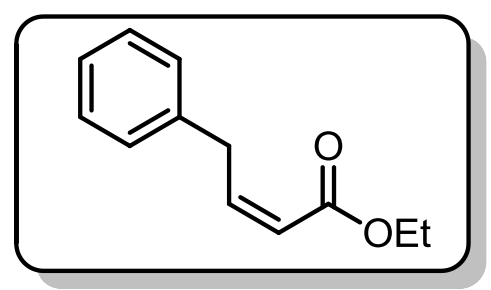

(Z)-Ethyl 4-Phenylbut-2-enoate, ${ }^{36}$ 3ac $(76 \mathrm{mg}, 80 \%)$ was prepared according to General Procedure A for photoredox cross-coupling of chloroalkene $2 \mathrm{n}(67 \mathrm{mg}, 0.5 \mathrm{mmol})$ and benzylsilicate 1e (263 mg, $0.006 \mathrm{~mol}, 1.2$ equiv). The desired cross-coupled alkene was obtained as a clear, yellow oil. ${ }^{1} \mathbf{H}$ NMR $\left(\mathrm{CDCl}_{3}, 500 \mathrm{MHz}\right) \delta 1.32(\mathrm{t}, J=7.0 \mathrm{~Hz}, 3 \mathrm{H}) 4.03(\mathrm{dd}, J$ $=7.6,1.5 \mathrm{~Hz}, 2 \mathrm{H}) 4.22(\mathrm{q}, J=7.6 \mathrm{~Hz}, 2 \mathrm{H}) 5.85(\mathrm{dt}, J=11.3,1.5$ $\mathrm{Hz}, 1 \mathrm{H}) 6.35(\mathrm{dt}, J=11.3,7.6 \mathrm{~Hz}, 1 \mathrm{H}) 7.21-7.25(\mathrm{~m}, 3 \mathrm{H}) 7.30(\mathrm{t}, J=7.3 \mathrm{~Hz}, 2 \mathrm{H}){ }^{13} \mathrm{C}$ NMR $\left(\mathrm{CDCl}_{3}, 125 \mathrm{MHz}\right) \delta 14.5\left(\mathrm{CH}_{3}\right), 35.4\left(\mathrm{CH}_{2}\right), 60.3\left(\mathrm{CH}_{2}\right), 120.2(\mathrm{CH}), 126.6(\mathrm{CH}), 128.9(\mathrm{CH})$, 139.7 (C), $148.2(\mathrm{CH}), 166.7$ (C). GC-MS (EI) 190 ([M] $\left.]^{+}, 76 \%\right), 162(14 \%), 144(55 \%), 133$ (38\%), 127 (16\%), 117 (72\%), 115 (100\%), 105 (11\%), 91 (40\%), 89 (12\%), $77(10 \%), 65$ (19\%), $58(8 \%), 51(9 \%)$. HRMS (ES+) calcd for $\mathrm{C}_{12} \mathrm{H}_{14} \mathrm{O}_{2} \mathrm{Na}[\mathrm{M}+\mathrm{Na}]^{+}: 213.0891$, found: 213.0896 . 


\section{Modified Procedure for Large Scale Cross-Coupling}

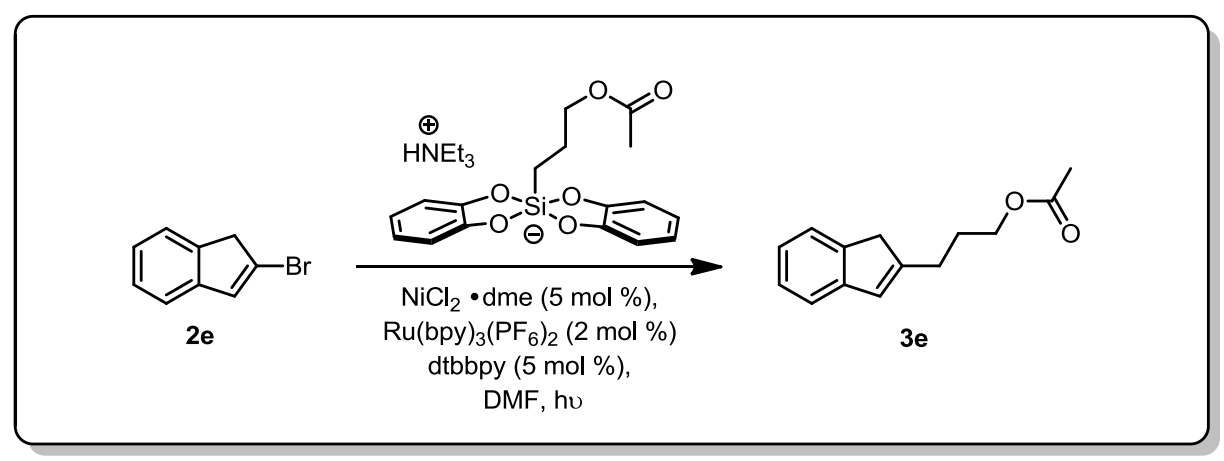

\section{3-(1H-Inden-2-yl)propyl Acetate (3e)}

To a Schlenk flask ${ }^{38}$ equipped with an appropriately sized stir bar was added the (3acetoxypropyl)silicate $\mathbf{1 a}\left(3.05 \mathrm{~g}, 6.6 \mathrm{mmol}, 1.2\right.$ equiv), $\mathrm{NiCl}_{2} \bullet \mathrm{dme}(60.4 \mathrm{mg}, 0.025 \mathrm{mmol}, 0.275$ equiv), dtbbpy (73.8 mg, 0.025, 0.275 equiv), and $\mathrm{Ru}(\mathrm{bpy})_{3}\left(\mathrm{PF}_{6}\right)$ (94.6 mg, $0.11 \mathrm{mmol}, 0.02$ equiv). The flask was sealed with a rubber septum and evacuated three times via its inlet valve and purged with argon. The flask was then charged via a syringe with the bromide $2 \mathrm{e}(1.07 \mathrm{~g}, 5.5$ mmol, 1 equiv) dissolved in anhyd, degassed DMF $(55 \mathrm{~mL})$. The now bright red solution was irradiated in the aforementioned LED reactor. ${ }^{39}$ The reaction was maintained at approximately $27{ }^{\circ} \mathrm{C}$ via a fan. The solution was stirred vigorously while being irradiated. Reaction progress was monitored by HPLC (or GC/MS). Once judged to be complete, the now opaque, milkybrown solution was transferred to a separatory funnel and diluted with deionized $\mathrm{H}_{2} \mathrm{O}(\sim 150 \mathrm{~mL})$ and $\mathrm{Et}_{2} \mathrm{O}(\sim 100 \mathrm{~mL})$. The layers were separated, and the aqueous layer was extracted with $\mathrm{Et}_{2} \mathrm{O}$ $(3 \times \sim 100 \mathrm{~mL})$. The combine organic layers were washed with $2 \mathrm{M} \mathrm{NaOH}(2 \times \sim 100 \mathrm{~mL}), 2 \mathrm{M}$ $\mathrm{HCl}(\sim 100 \mathrm{~mL})$, deionized $\mathrm{H}_{2} \mathrm{O}(\sim 100 \mathrm{~mL})$, and brine $(\sim 100 \mathrm{~mL})$. The organic layer was dried $\left(\mathrm{MgSO}_{4}\right)$ and the solvent was removed in vacuo by rotary evaporation. Further purification was accomplished by passing the crude material over a pad of silica, eluting with two volumes of hexane and discarding the eluate followed by 95:5 to 9:1 hexane/EtOAc to give the desired alkene, 3e, as a clear colorless oil (0.898 g, 75\%).

${ }^{1} \mathrm{H} \mathrm{NMR}\left(\mathrm{CDCl}_{3}, 500 \mathrm{MHz}\right) \delta 1.96(\mathrm{dt}, J=15.2,6.6 \mathrm{~Hz}, 2 \mathrm{H}), 2.05(\mathrm{~s}, 3 \mathrm{H}), 2.56(\mathrm{t}, J=7.5 \mathrm{~Hz}$, $2 \mathrm{H}), 3.32(\mathrm{~s}, 2 \mathrm{H}), 4.13(\mathrm{t}, J=6.6 \mathrm{~Hz}, 2 \mathrm{H}), 6.53(\mathrm{~s}, 1 \mathrm{H}), 7.10(\mathrm{td}, J=7.4,1.2 \mathrm{~Hz}, 1 \mathrm{H}), 7.22(\mathrm{t}, J=$ $7.5 \mathrm{~Hz}, 1 \mathrm{H}), 7.27(\mathrm{~d}, J=7.3 \mathrm{~Hz}, 1 \mathrm{H}), 7.37(\mathrm{dd}, J=7.3,0.5 \mathrm{~Hz}, 1 \mathrm{H}) .{ }^{13} \mathrm{C} \mathrm{NMR}\left(\mathrm{CDCl}_{3}, 125\right.$ $\mathrm{MHz}) \delta 21.2\left(\mathrm{CH}_{3}\right), 27.8\left(\mathrm{CH}_{2}\right), 28.2\left(\mathrm{CH}_{2}\right), 41.3\left(\mathrm{CH}_{2}\right), 64.3\left(\mathrm{CH}_{2}\right), 120.3(\mathrm{CH}), 123.7(\mathrm{CH})$, $124.0(\mathrm{CH}), 126.6(\mathrm{CH}), 127.0(\mathrm{CH}), 143.2(\mathrm{C}), 145.6(\mathrm{C}), 149.3(\mathrm{C}), 171.4(\mathrm{C})$. GC-MS (EI) $216\left([\mathrm{M}]^{+}, 35 \%\right), 156(87 \%), 141(81 \%), 128(100 \%), 115(52 \%), 102(5 \%), 91(5 \%), 77(5 \%)$, 63 (4\%), 51 (3\%). HRMS (ES+) calcd for $\mathrm{C}_{14} \mathrm{H}_{16} \mathrm{O}_{2} \mathrm{Na}[\mathrm{M}+\mathrm{Na}]^{+}: 239.1048$, found: 239.1055.

\footnotetext{
${ }^{38}$ Note that Schlenk flask or round bottom flask could interchangeably be used with no difference in reaction yield.

${ }^{39}$ Note that both blue and white LEDs can be used interchangeably with no difference in reaction yield.
} 


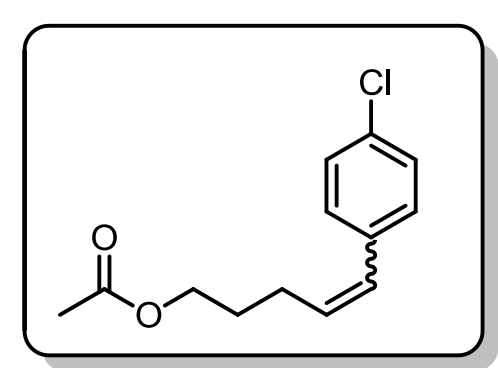

(Z)-5-(4-Chlorophenyl)pent-4-en-1-yl Acetate, 3d (0.833 g, $76 \%$ ) was prepared according to a modified procedure for large scale photoredox cross-coupling of $\mathbf{2 d}(1.00 \mathrm{~g}, 4.60 \mathrm{mmol})$ and (3-acetoxypropyl)silicate $\mathbf{1 a}(2.47 \mathrm{~g}, 5.52 \mathrm{mmol}, 1.2$ equiv). The desired cross-coupled alkene was obtained as a pale yellow semisolid. ${ }^{1} \mathrm{H}$ NMR $\left(\mathrm{CDCl}_{3}, 500 \mathrm{MHz}\right) \delta 1.74-1.82(\mathrm{~m}, 2 \mathrm{H}), 2.00$ $(\mathrm{s}, 3 \mathrm{H}), 2.37(\mathrm{qd}, J=7.4,1.8 \mathrm{~Hz}, 2 \mathrm{H}), 4.07(\mathrm{t}, J=6.6 \mathrm{~Hz}, 2 \mathrm{H})$, $5.66(\mathrm{dt}, J=11.7,7.3 \mathrm{~Hz}, 1 \mathrm{H}), 6.41(\mathrm{~d}, J=11.7 \mathrm{~Hz}, 1 \mathrm{H}), 7.18(\mathrm{~d}$, $J=8.5 \mathrm{~Hz}, 2 \mathrm{H}), 7.30(\mathrm{~d}, J=8.5 \mathrm{~Hz}, 2 \mathrm{H}) .{ }^{13} \mathrm{C} \mathrm{NMR}\left(\mathrm{CDCl}_{3}, 125 \mathrm{MHz}\right) \delta 21.1\left(\mathrm{CH}_{3}\right), 25.1$ $\left(\mathrm{CH}_{2}\right), 28.8\left(\mathrm{CH}_{2}\right), 63.9\left(\mathrm{CH}_{2}\right), 128.5(\mathrm{CH}), 128.9(\mathrm{CH}), 130.2(\mathrm{CH}), 132.2(\mathrm{CH}), 132.6(\mathrm{C})$, $136.0(\mathrm{C}), 171.2(\mathrm{C})$. GC-MS (EI) $\left.240\left([\mathrm{M}]^{+},{ }^{37} \mathrm{Cl} 1 \%\right), 238([\mathrm{M}]]^{+},{ }^{35} \mathrm{Cl} 2 \%\right), 180\left({ }^{37} \mathrm{Cl} 10 \%\right)$, $178\left({ }^{35} \mathrm{Cl} 29 \%\right), 165\left({ }^{37} \mathrm{Cl}, 5 \%\right), 163\left({ }^{35} \mathrm{Cl} 13 \%\right), 151(8 \%), 143$ (100\%), 128 (40\%), 115 (25\%), 89 (4\%), 75 (3\%). HRMS (CI+) calcd for $\mathrm{C}_{13} \mathrm{H}_{15} \mathrm{ClO}_{2}$ [M]+: 238.0761, found: 238.0762. 


\section{Reaction Monitoring and Control Studies}

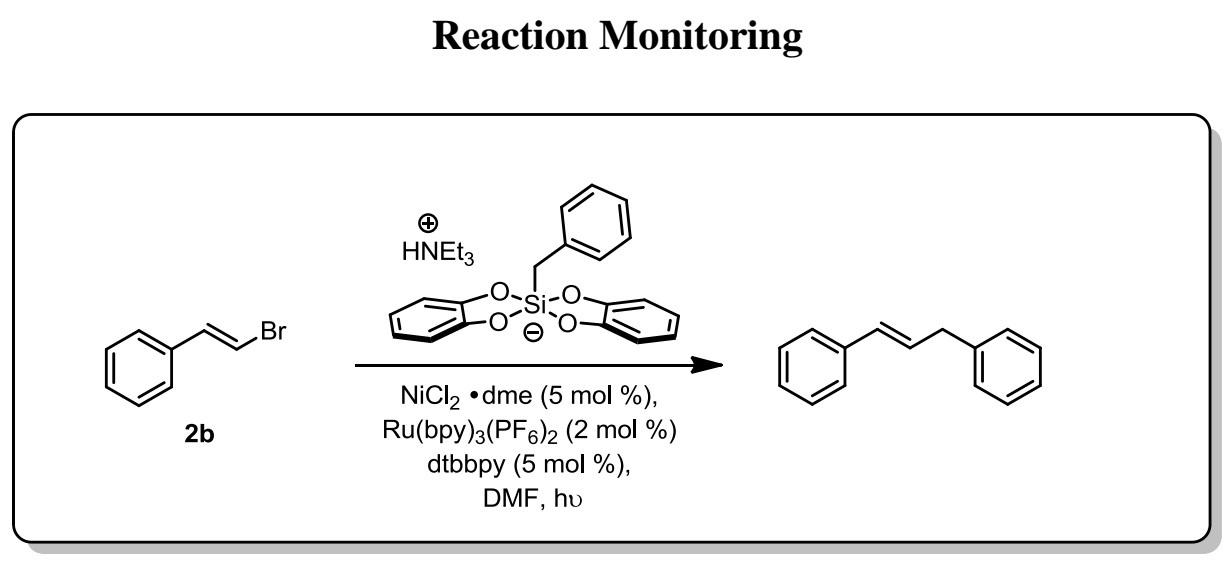

To an $8 \mathrm{~mL}$ reaction vial equipped with an appropriately sized stir bar were added the silicate 1e ( $268 \mathrm{mg}, 0.6 \mathrm{mmol}, 1.2$ equiv), $\mathrm{NiCl}_{2} \bullet \mathrm{dme}(5.5 \mathrm{mg}, 0.025 \mathrm{mmol}, 0.05$ equiv), dtbbpy (6.7 mg, 0.025, 0.05 equiv), $\mathrm{Ru}(\mathrm{bpy})_{3}\left(\mathrm{PF}_{6}\right)(8.6 \mathrm{mg}, 0.01 \mathrm{mmol}, 0.02$ equiv), and 4,4'-di-tertbutylbiphenyl (internal standard, $13.3 \mathrm{mg}, 0.05 \mathrm{mmol}, 0.1$ equiv). The vial was sealed with a cap containing a TFE-lined silicone septa and was evacuated three times via an inlet needle and purged with argon. The vial was then charged with the iodide $\mathbf{2 b}(91.5 \mathrm{mg}, 0.5 \mathrm{mmol}, 1$ equiv) dissolved in anhyd, degassed DMF (5 mL) via a syringe. The cap was sealed with Parafilm, and the now bright red solution was irradiated in front of a CFL. The reaction was maintained at approximately $27^{\circ} \mathrm{C}$ via a fan. The solution was stirred vigorously while being irradiated. At each time point, $0.5 \mathrm{~mL}$ aliquots were taken from the reaction vessel via a syringe. Aliquots were diluted with $1.5 \mathrm{~mL}$ of MeCN. The reaction progress was monitored by HPLC and GC-MS. Depending on the combination of silicate and alkenyl halide, reaction times varied.

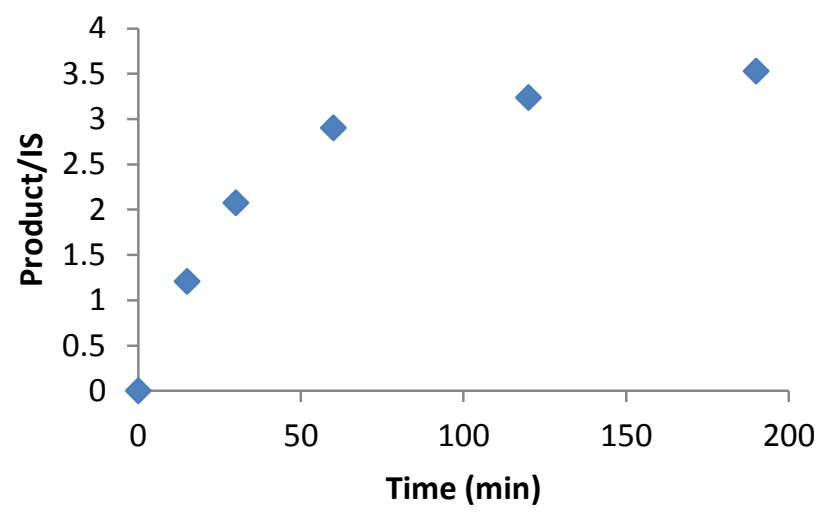

\section{Control studies}

\section{Experiment 1}

To a 2 dram reaction vial equipped with an appropriately sized stir bar were added the silicate $1 \mathrm{e}\left(52 \mathrm{mg}, 0.12 \mathrm{mmol}, 1.2\right.$ equiv), $\mathrm{NiCl}_{2} \bullet \mathrm{dme}$ ( $1.1 \mathrm{mg}, 0.005 \mathrm{mmol}, 0.05$ equiv), dtbbpy 
(1.34 mg, 0.005, 0.05 equiv), and $\mathrm{Ru}(\mathrm{bpy})_{3}\left(\mathrm{PF}_{6}\right)(1.7 \mathrm{mg}, 0.002 \mathrm{mmol}, 0.02$ equiv). The vial was sealed with a cap containing a TFE-lined silicone cap and was evacuated three times via an inlet needle and purged with argon. The vial was then charged with the iodide $\mathbf{2 b}(91.5 \mathrm{mg}, 0.5 \mathrm{mmol}$, 1 equiv) dissolved in anhyd, degassed DMF (5 mL) via a syringe. The cap was sealed with Parafilm, and the reaction vial was covered with aluminum foil. The solution was stirred vigorously in the dark. After $24 \mathrm{~h}$, the reaction progress was monitored by HPLC and GC-MS, showing no formation of cross-coupled product.

\section{Experiment 2}

To a 2 dram reaction vial equipped with an appropriately sized stir bar were added the silicate $1 \mathrm{e}\left(52 \mathrm{mg}, 0.12 \mathrm{mmol}, 1.2\right.$ equiv), $\mathrm{NiCl}_{2} \bullet \mathrm{dme}$ ( $1.1 \mathrm{mg}, 0.005 \mathrm{mmol}, 0.05$ equiv), and dtbbpy ( $1.34 \mathrm{mg}, 0.005,0.05$ equiv). The vial was sealed with a cap containing a TFE-lined silicone cap and was evacuated three times via an inlet needle and purged with argon. The vial was then charged via a syringe with the iodide $\mathbf{2 b}(91.5 \mathrm{mg}, 0.5 \mathrm{mmol}, 1$ equiv) dissolved in anhyd, degassed DMF (5 mL). The cap was sealed with Parafilm, and the now bright red solution was irradiated in front of a CFL. The reaction was maintained at approximately $27{ }^{\circ} \mathrm{C}$ $v i a$ a fan. The solution was stirred vigorously while being irradiated. After $24 \mathrm{~h}$, reaction progress was monitored by HPLC and GC-MS, showing no formation of cross-coupled product.

\section{Experiment 3}

To a 2 dram reaction vial equipped with an appropriately sized stir bar were added the silicate 1e ( $52 \mathrm{mg}, 0.12 \mathrm{mmol}, 1.2$ equiv) and $\mathrm{Ru}\left(\mathrm{bpy}_{3}\right)_{3}\left(\mathrm{PF}_{6}\right)(1.7 \mathrm{mg}, 0.002 \mathrm{mmol}, 0.02$ equiv). The vial was sealed with a cap containing a TFE-lined silicone cap and was evacuated three times via an inlet needle and purged with argon. The vial was then charged via a syringe with the iodide $2 \mathbf{b}$ ( $91.5 \mathrm{mg}, 0.5 \mathrm{mmol}, 1$ equiv) dissolved in anhyd, degassed DMF ( $5 \mathrm{~mL})$. The cap was sealed with Parafilm, and the now bright red solution was irradiated in front of a CFL. The reaction was maintained at approximately $27{ }^{\circ} \mathrm{C} v i a$ a fan. The solution was stirred vigorously while being irradiated. After $24 \mathrm{~h}$, reaction progress was monitored by HPLC and GC-MS, showing trace conversion to cross-coupled product.

\begin{tabular}{|c|c|c|}
\hline experiment \# & conditions & yield (determined by HPLC) \\
\hline 1 & no light & $0 \%$ \\
\hline 2 & no $\mathrm{Ru}$ photocatalyst & $0 \%$ \\
\hline 3 & no $\mathrm{NiCl}_{2} \cdot \mathrm{dme}$ & $<5 \%$ \\
\hline
\end{tabular}




\section{${ }^{1}$ H NMR Spectra of Synthesized Compounds}

triethylammonium bis(catecholato)cyclopentylsilicate $500 \mathrm{MHz}$, DMSO-d6
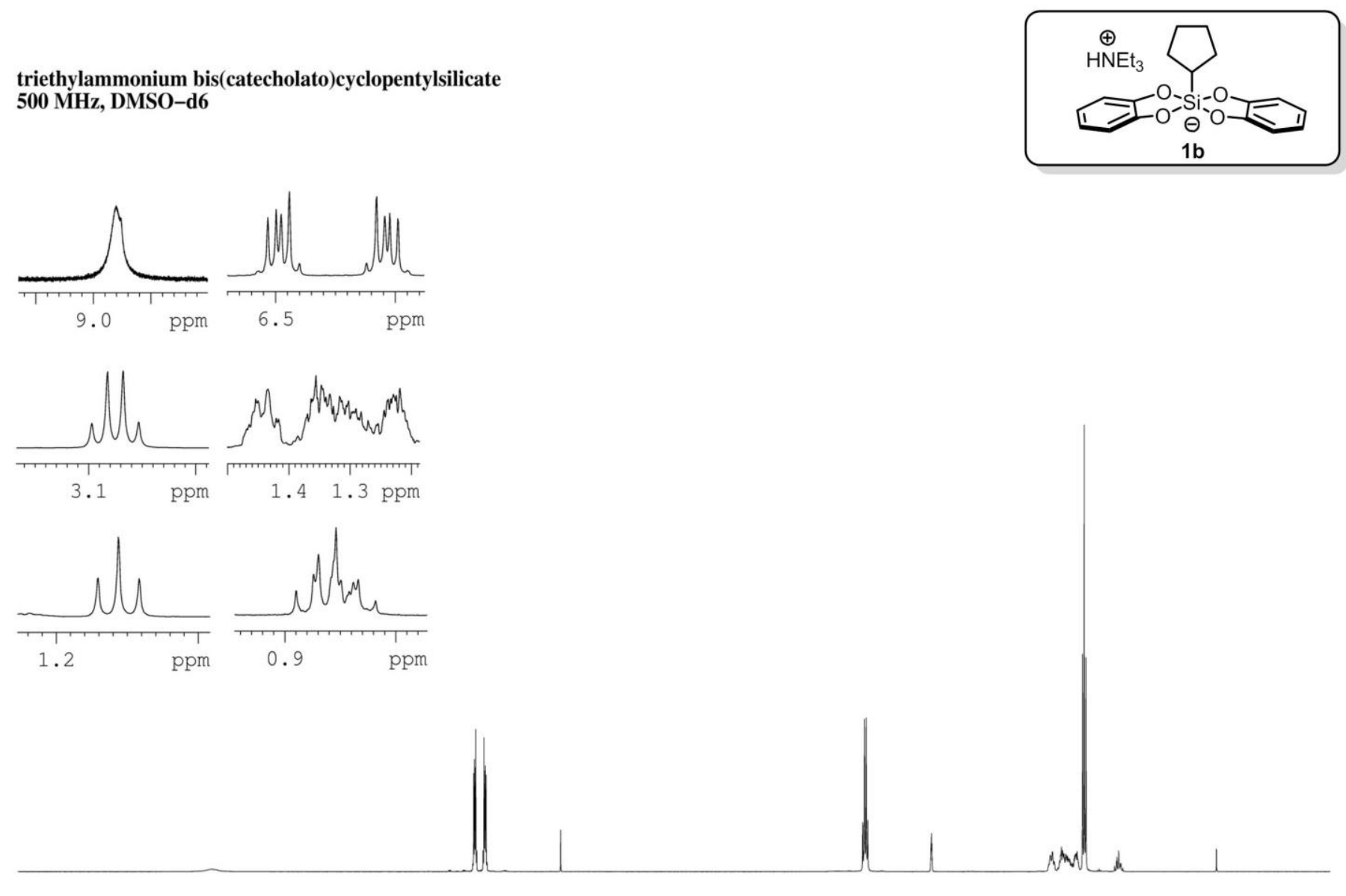

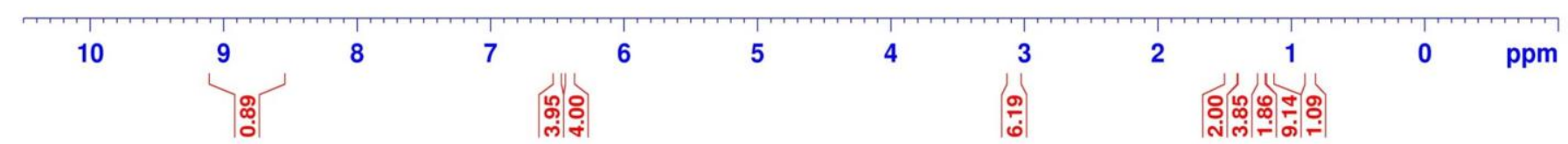


triethylammonium bis(catecholato)allylsilicate

500 MHz, DMSO-d6
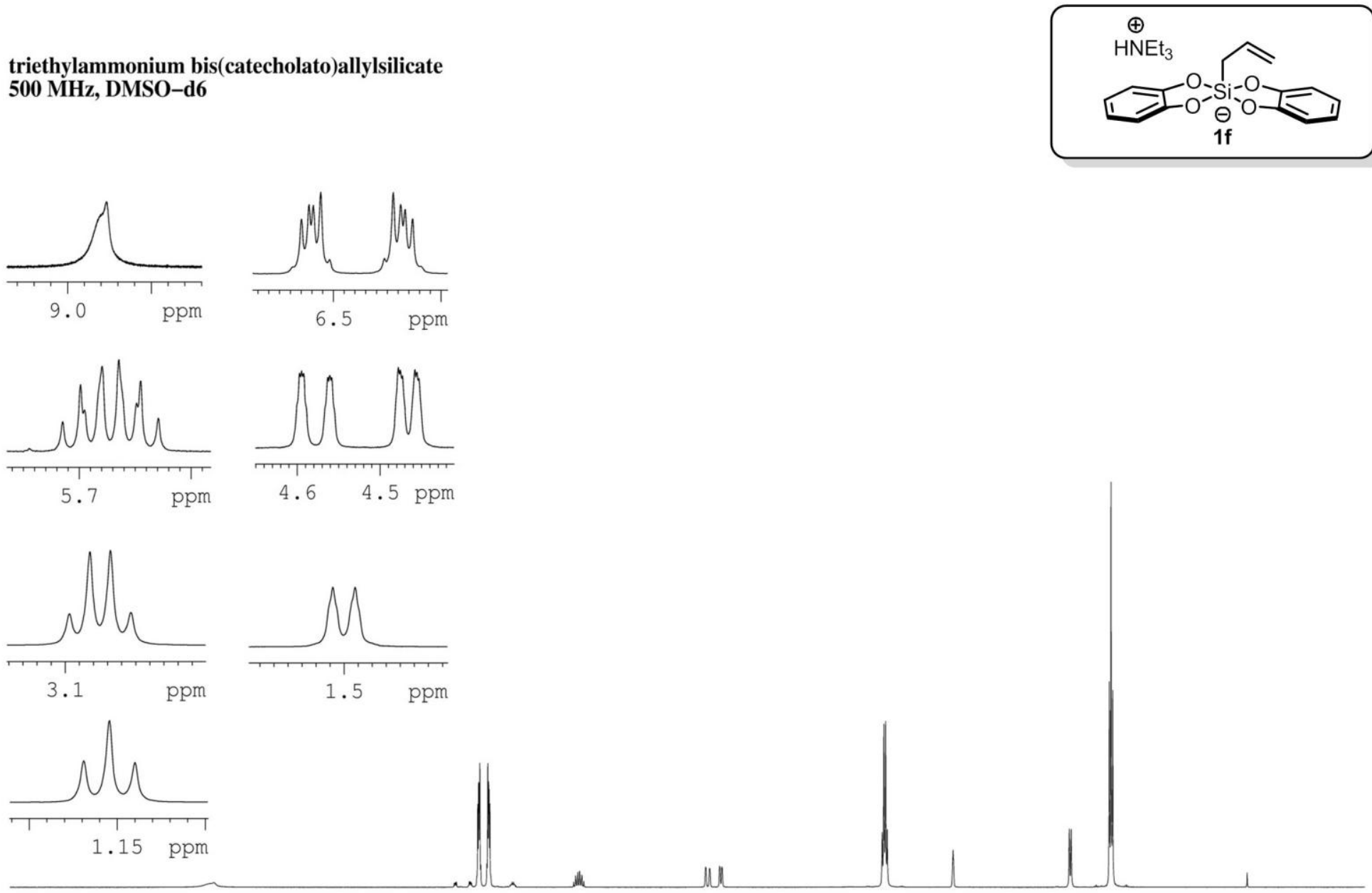

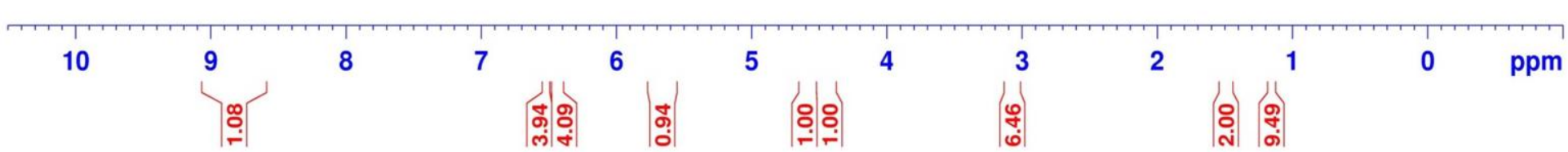


diisopropylammonium bis(catecholato)isobutylsilicate 500 MHz, DMSO-d6
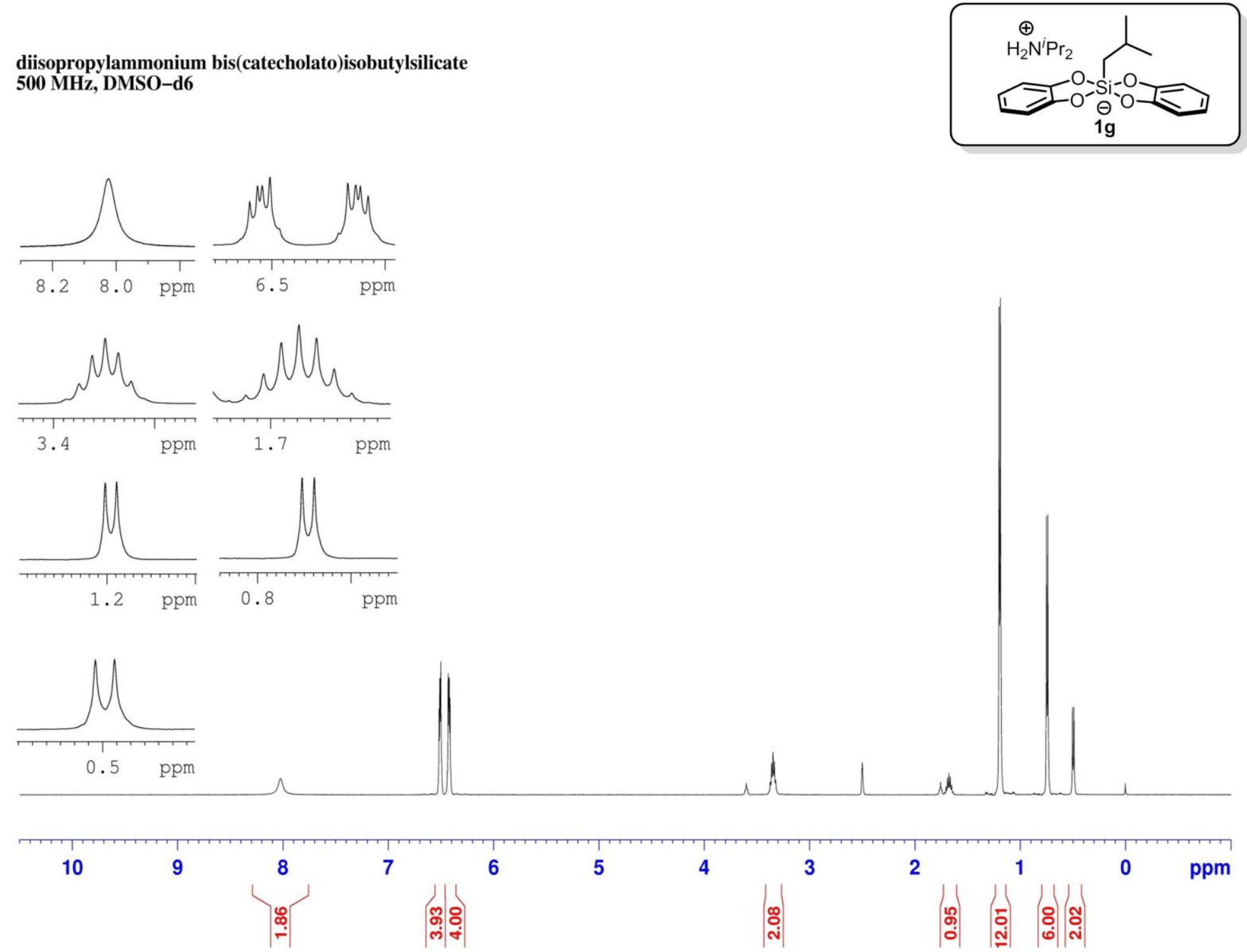
diisopropylammonium bis(catecholato)(3-methoxypropyl)silicate 500 MHz, DMSO-d6
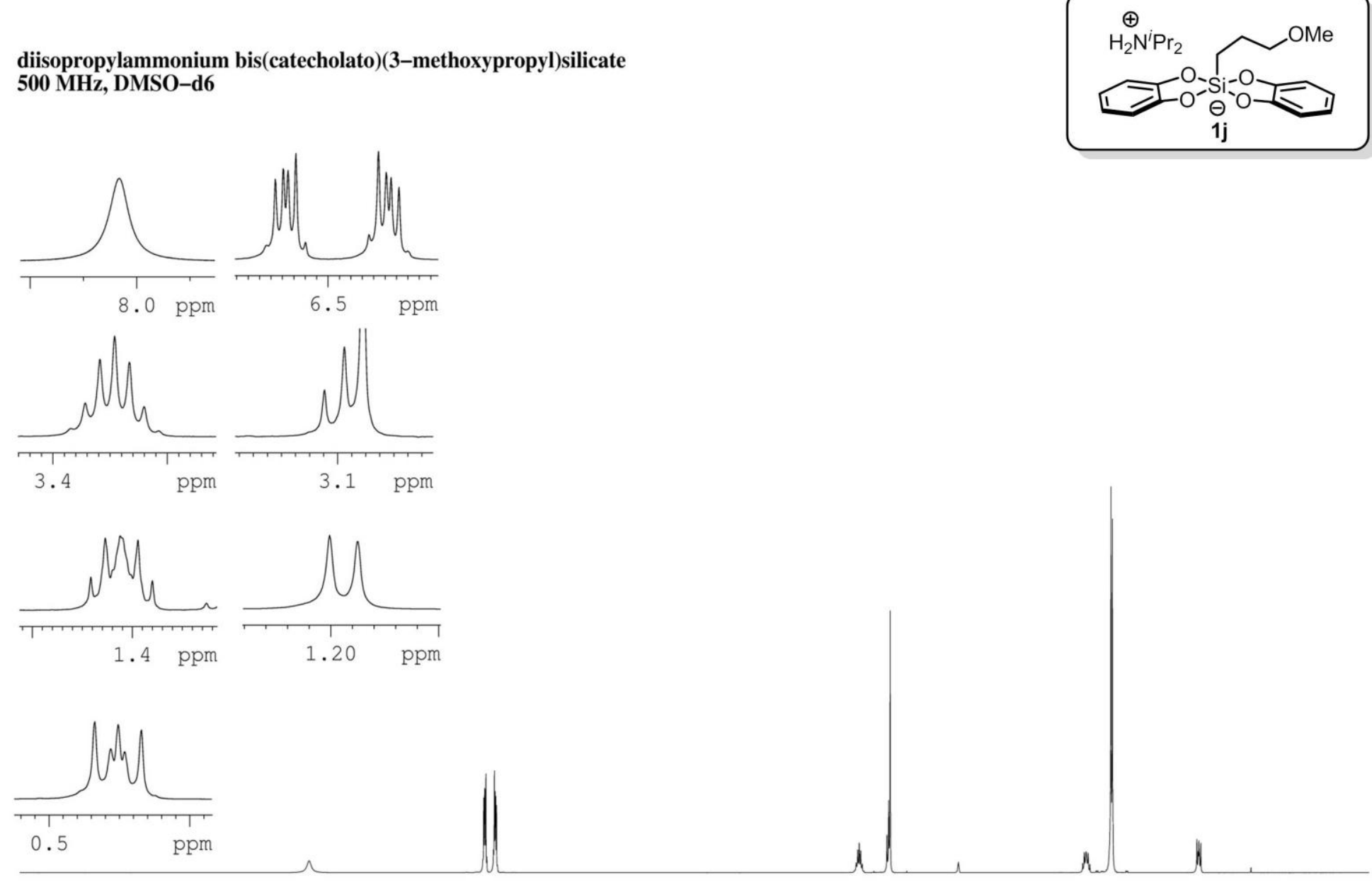

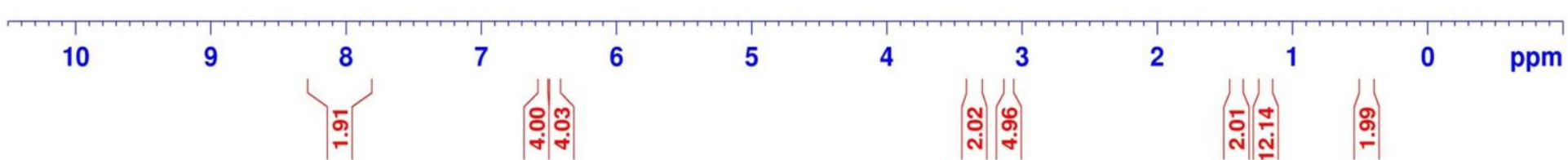


diisopropylammonium bis(catecholato)(3-acetamidopropyl)silicate 500 MHz, DMSO-d6
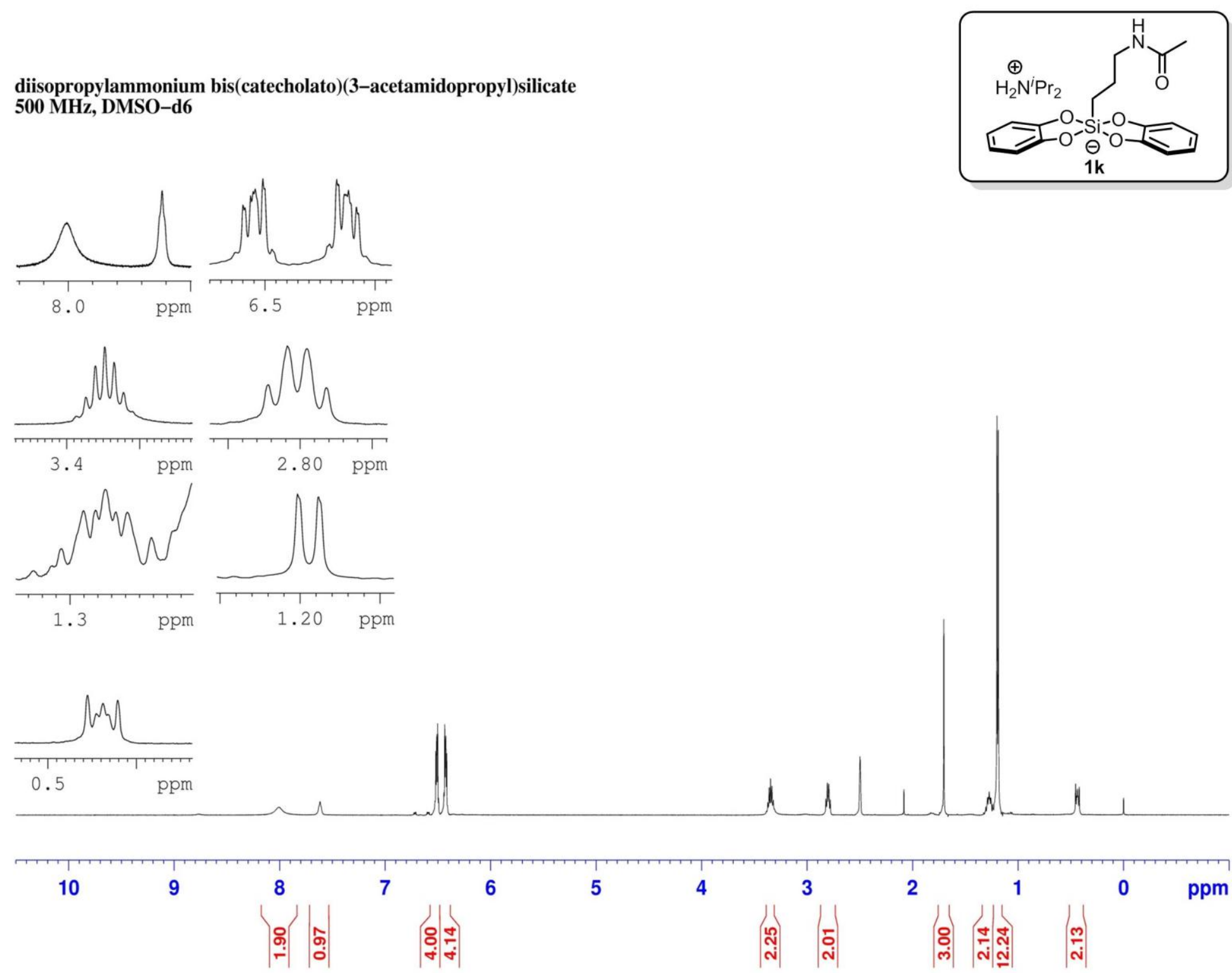

6

4

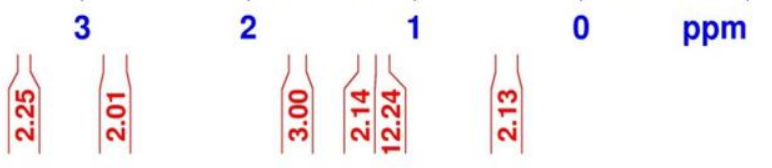


(E)-1-(2-bromovinyl)-4-methoxybenzene $500 \mathrm{MHz}, \mathrm{CDCl} 3$
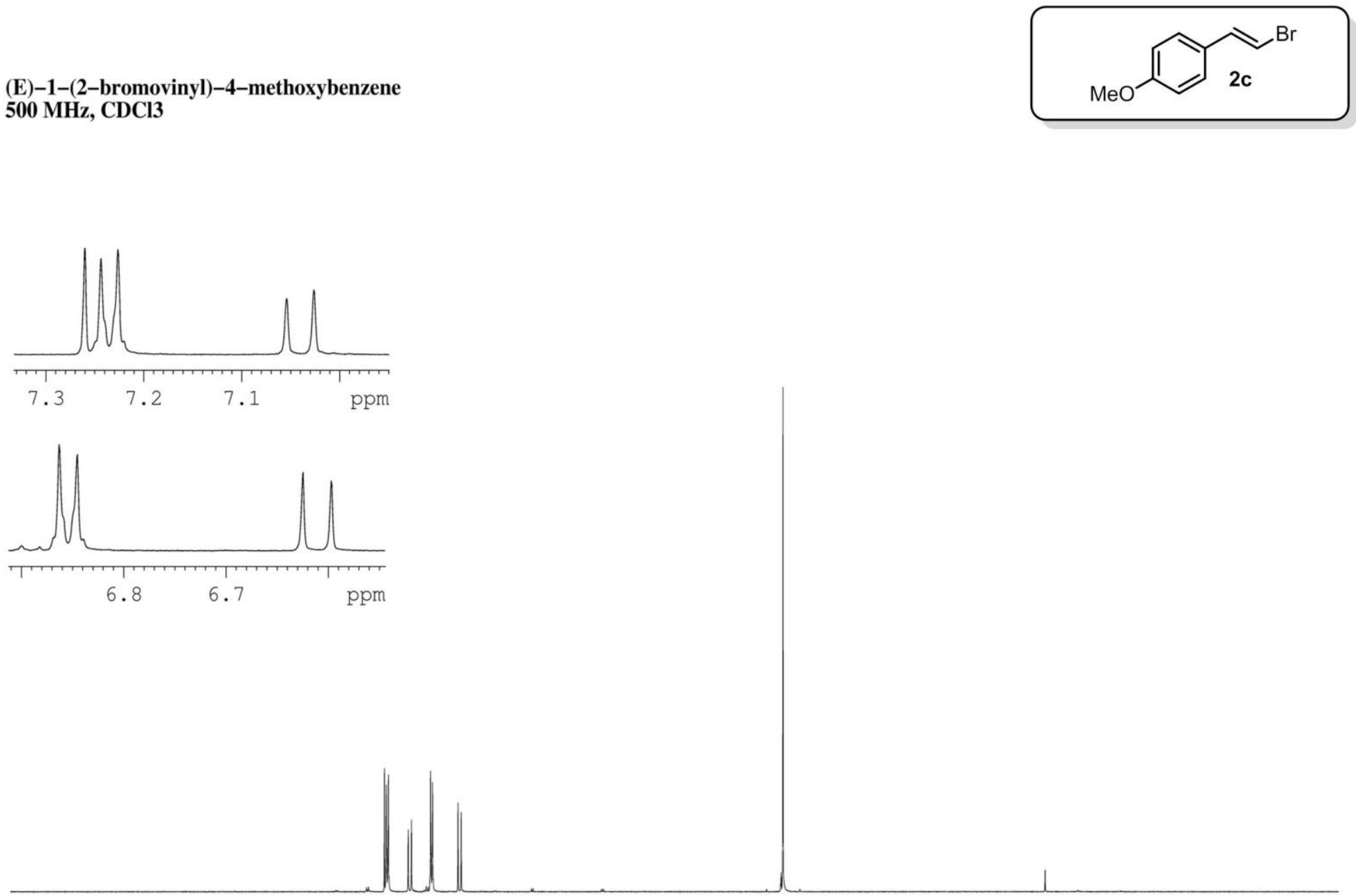

$\begin{array}{llllllllllllll}10 & 9 & 8 & 7 & 6 & 5 & 4 & 3 & 2 & 1 & 0 & \mathrm{ppm}\end{array}$


(Z)-1-(2-bromovinyl)-4-chlorobenzene

$500 \mathrm{MHz}, \mathrm{CDCl} 3$
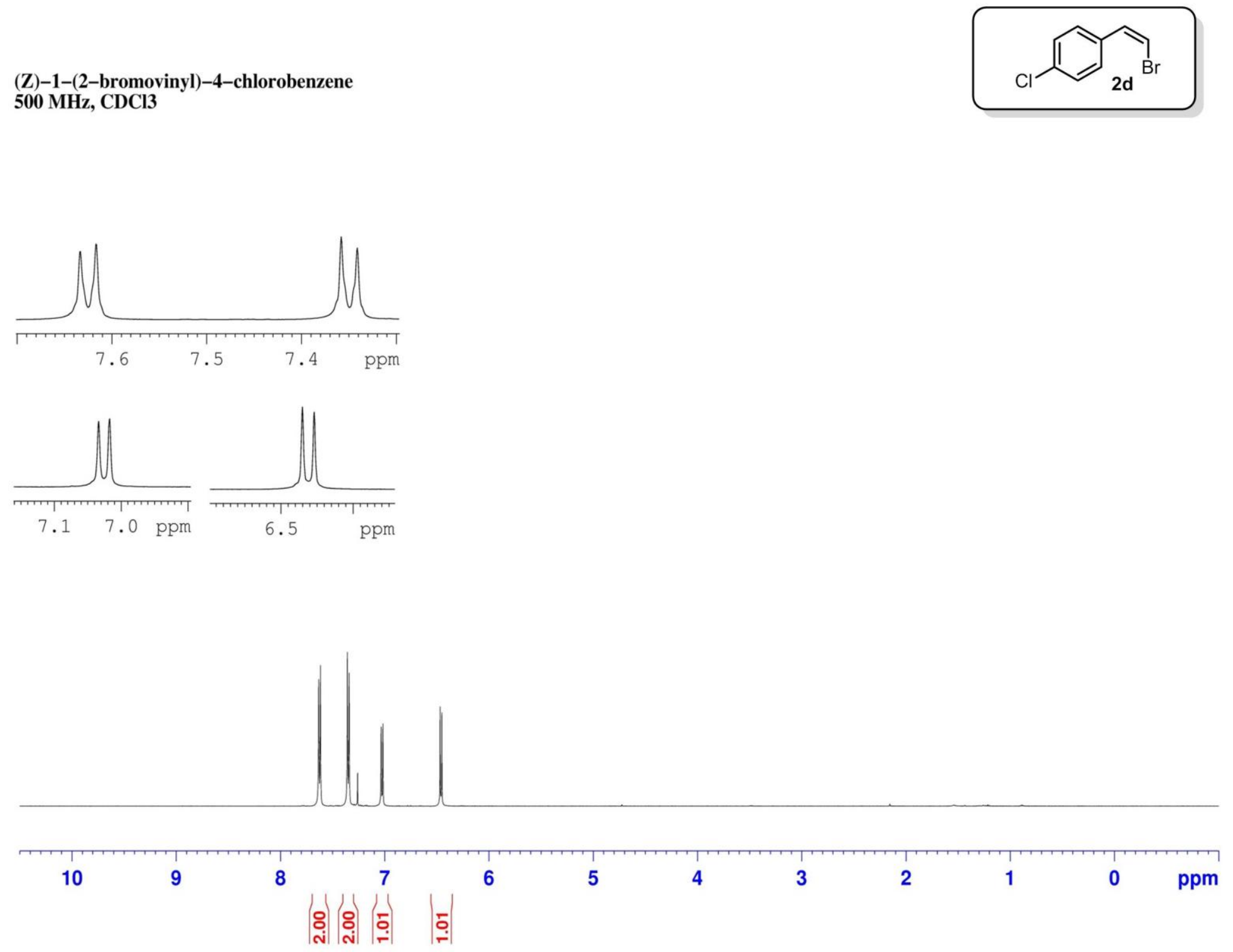
(E)-1-bromocyclooct-1-ene

$500 \mathrm{MHz}, \mathrm{CDCl} 3$
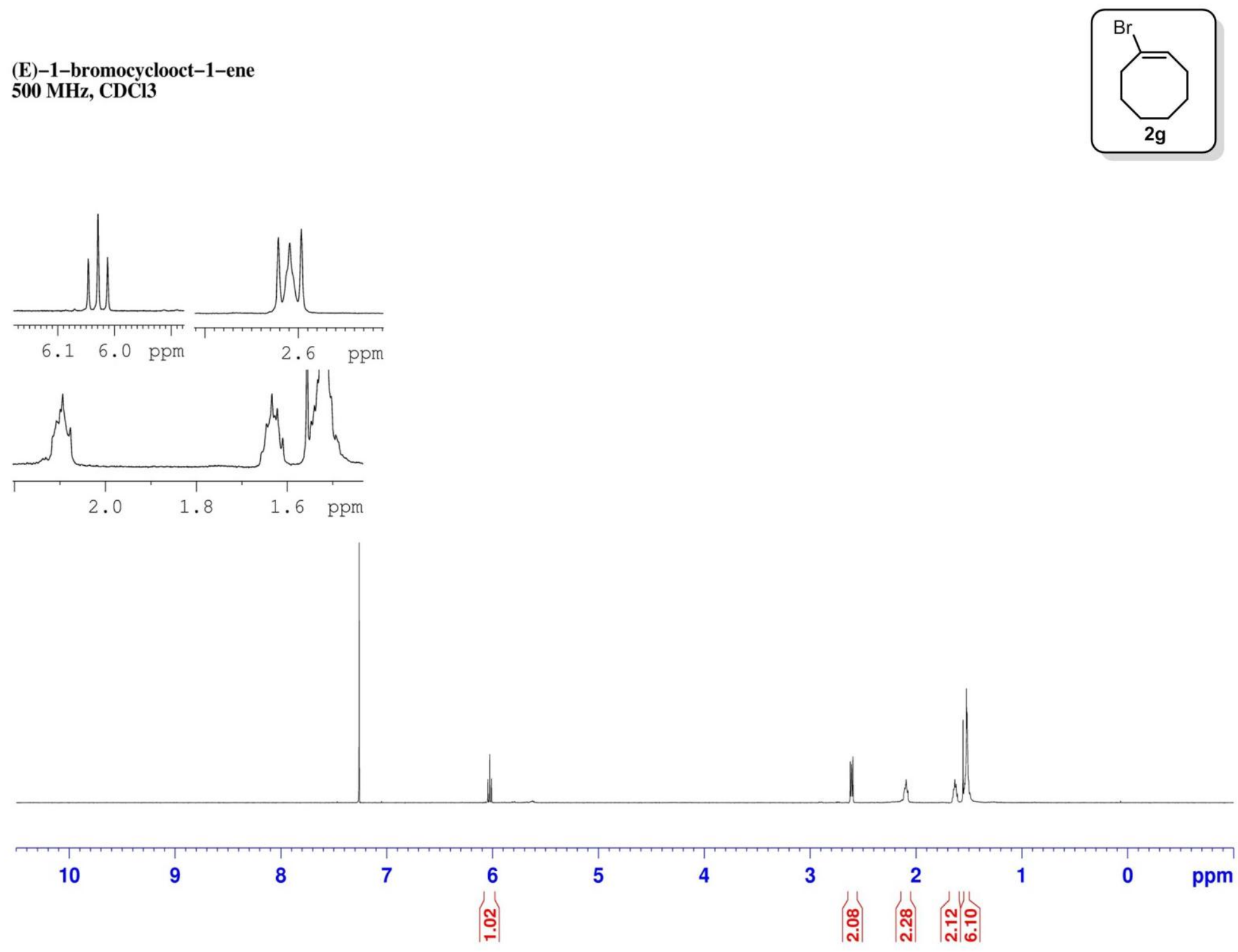
(E)-1-iodocyclooct-1-ene

$500 \mathrm{MHz}, \mathrm{CDCl} 3$
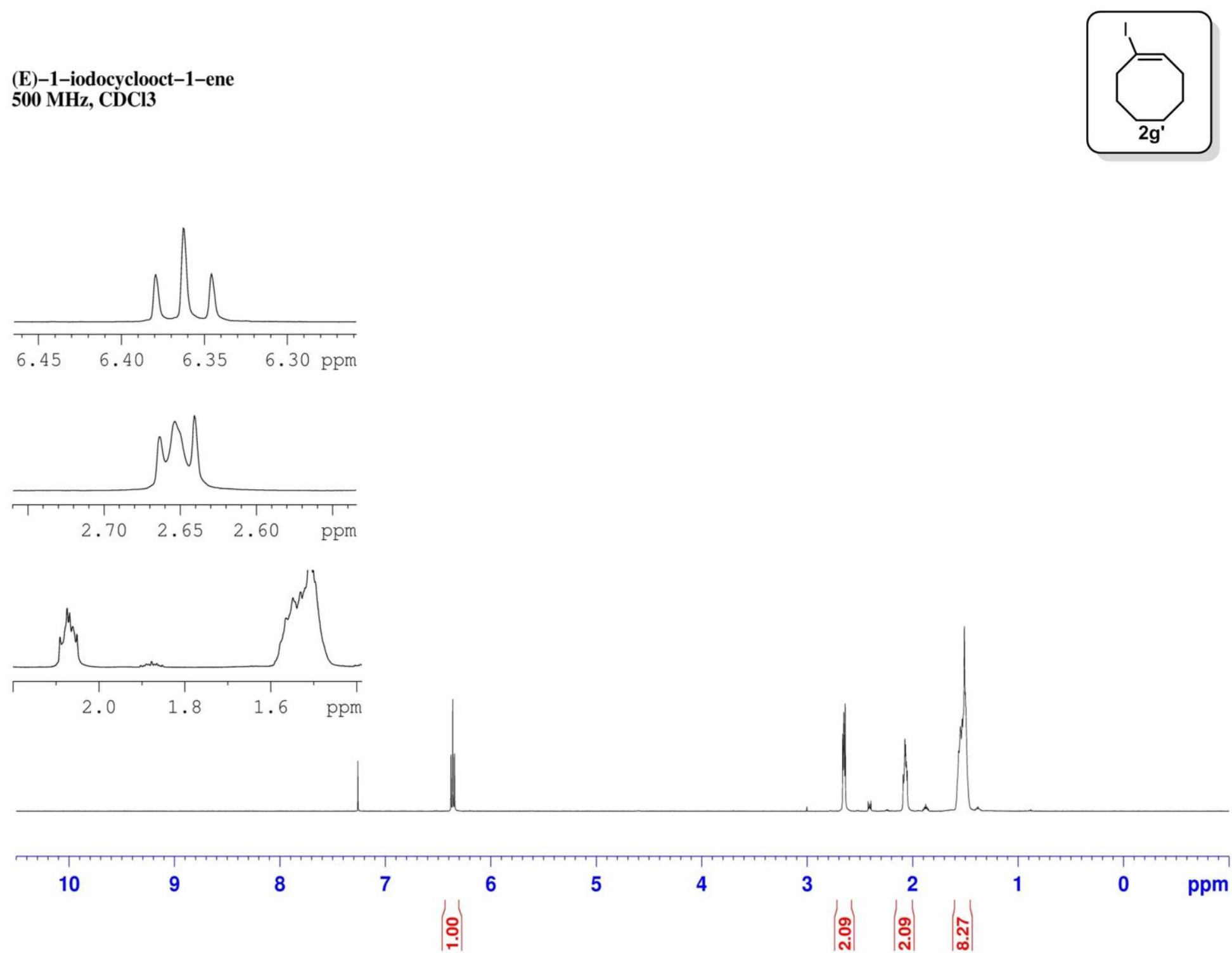
(Z)-3-bromoprop-2-en-1-ol
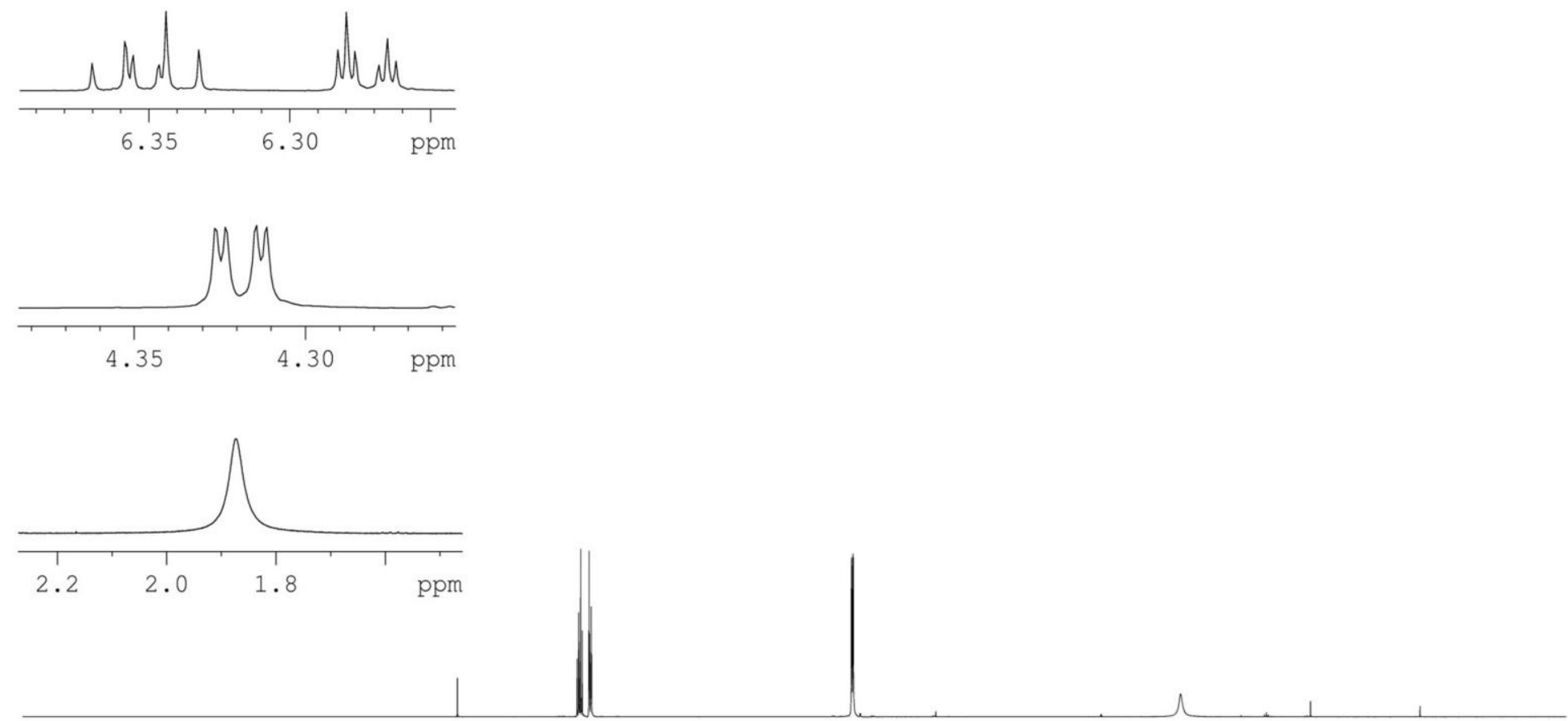

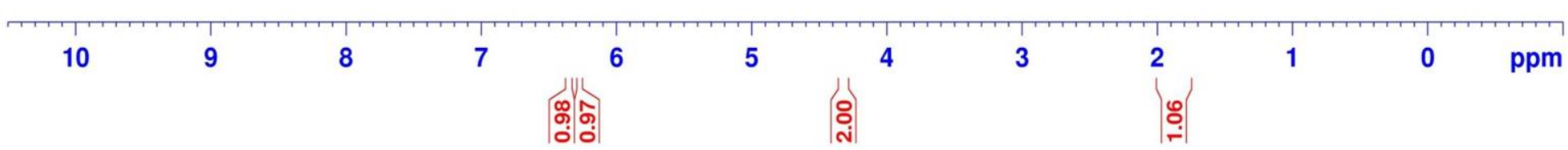


(Z)-((3-bromoallyl)oxy)(tert-butyl)dimethylsilane

$$
\mathrm{Br}_{\mathbf{2 k}} \text { —oTBS }
$$
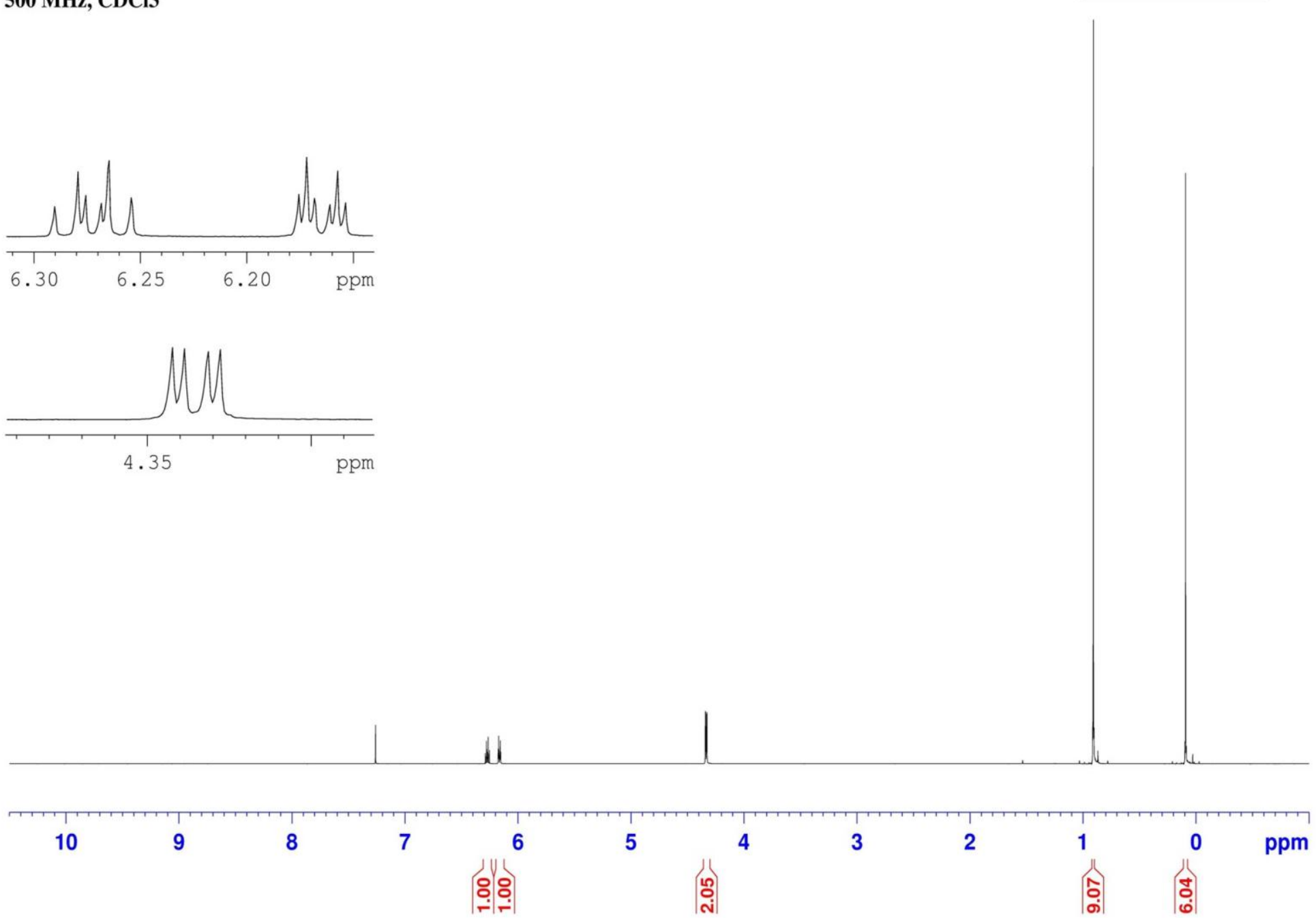
(E)-1-(2-chlorovinyl)-4-methoxybenzene $500 \mathrm{MHz}, \mathrm{CDCl} 3$
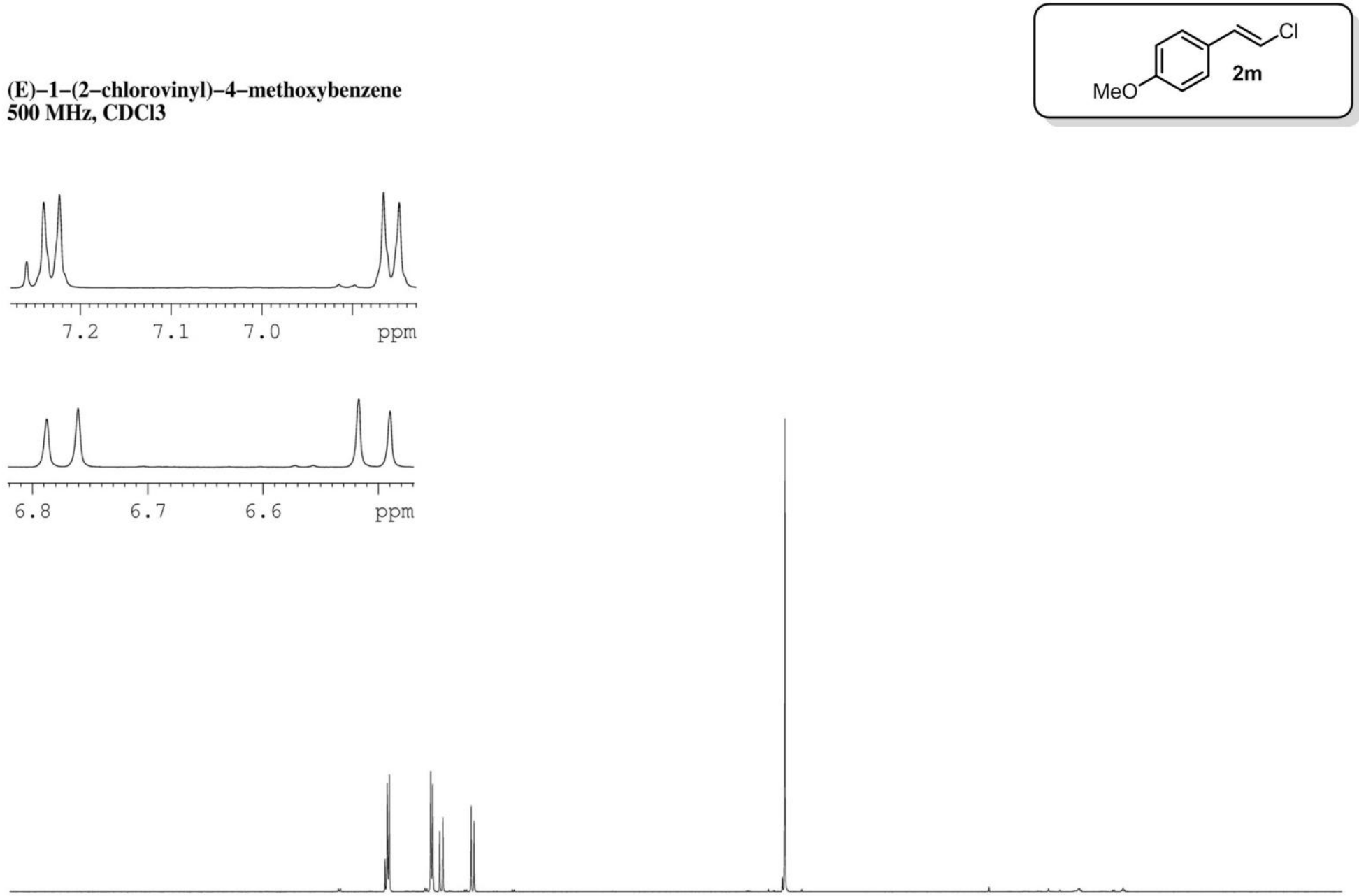

$\begin{array}{lllllllllllll}10 & 9 & 8 & 7 & 6 & 5 & 4 & 3 & 2 & 1 & 0 & \mathrm{ppm}\end{array}$


(Z)-ethyl 3-chloroacrylate
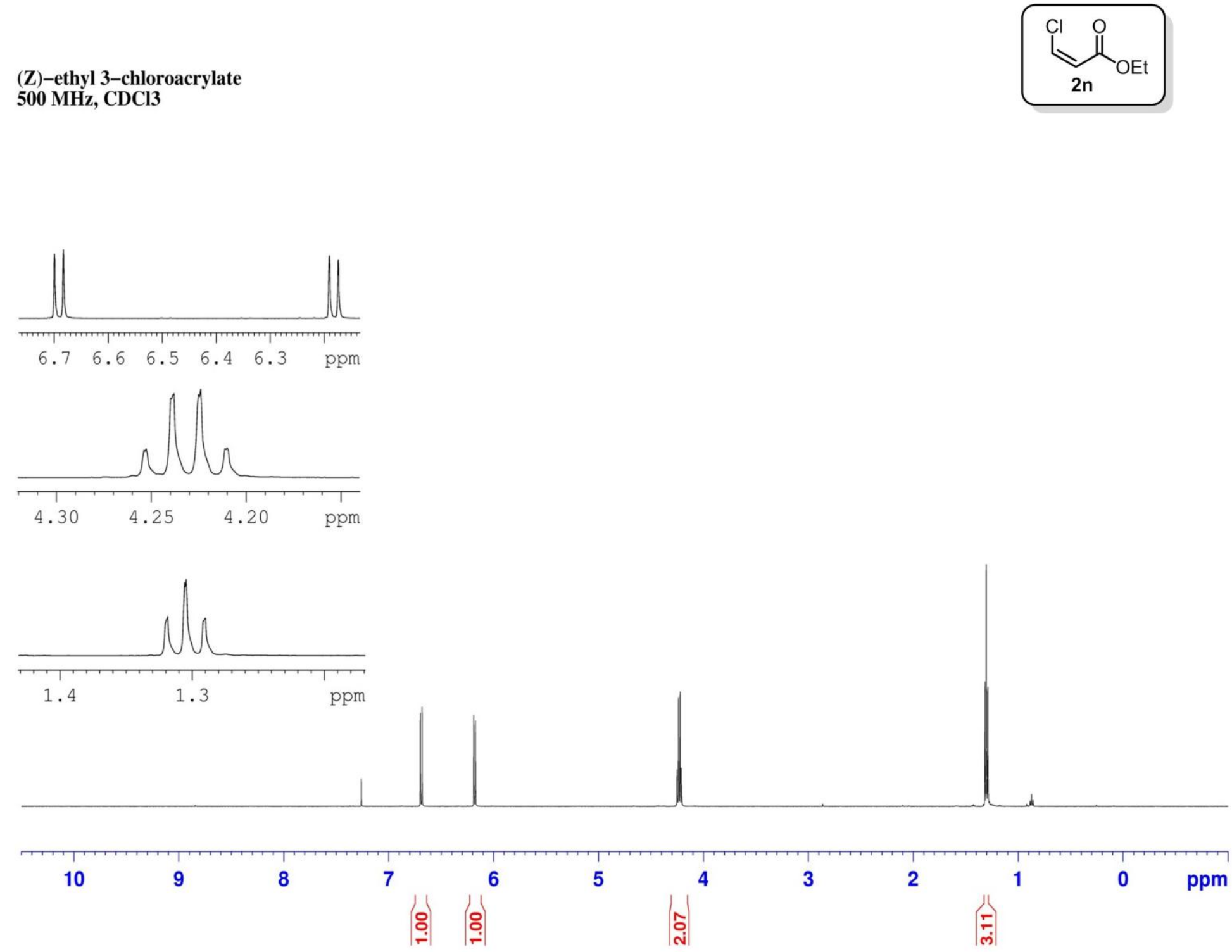
(E)-undec-4-en-1-yl acetate

$500 \mathrm{MHz}, \mathrm{CDCl} 3$
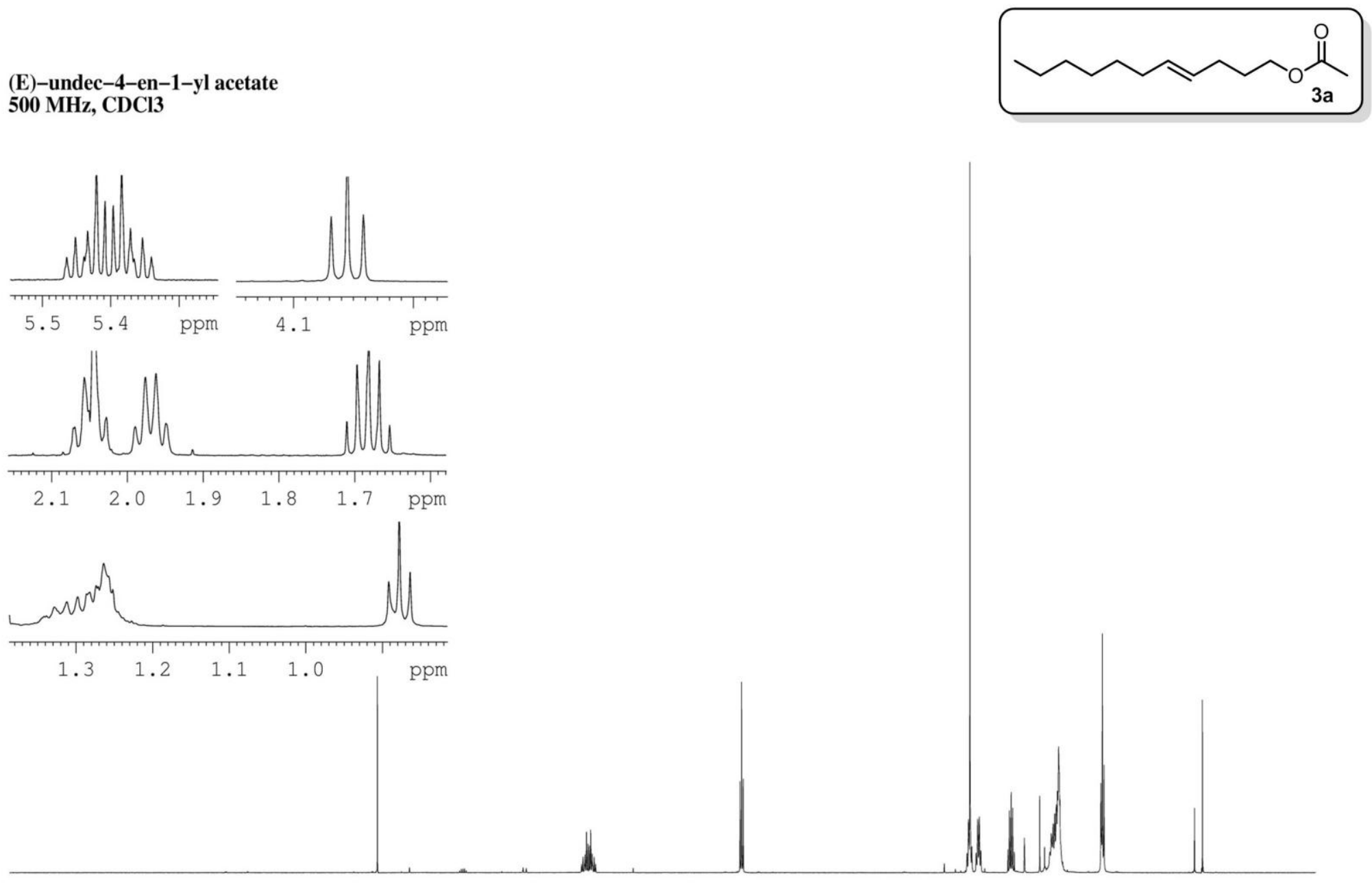

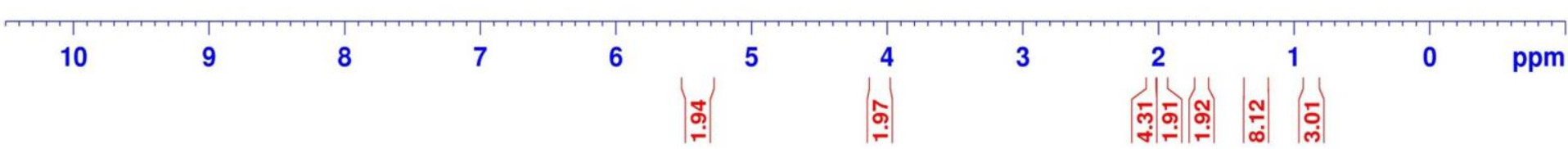


5-phenylpent-4-en-1-yl acetate
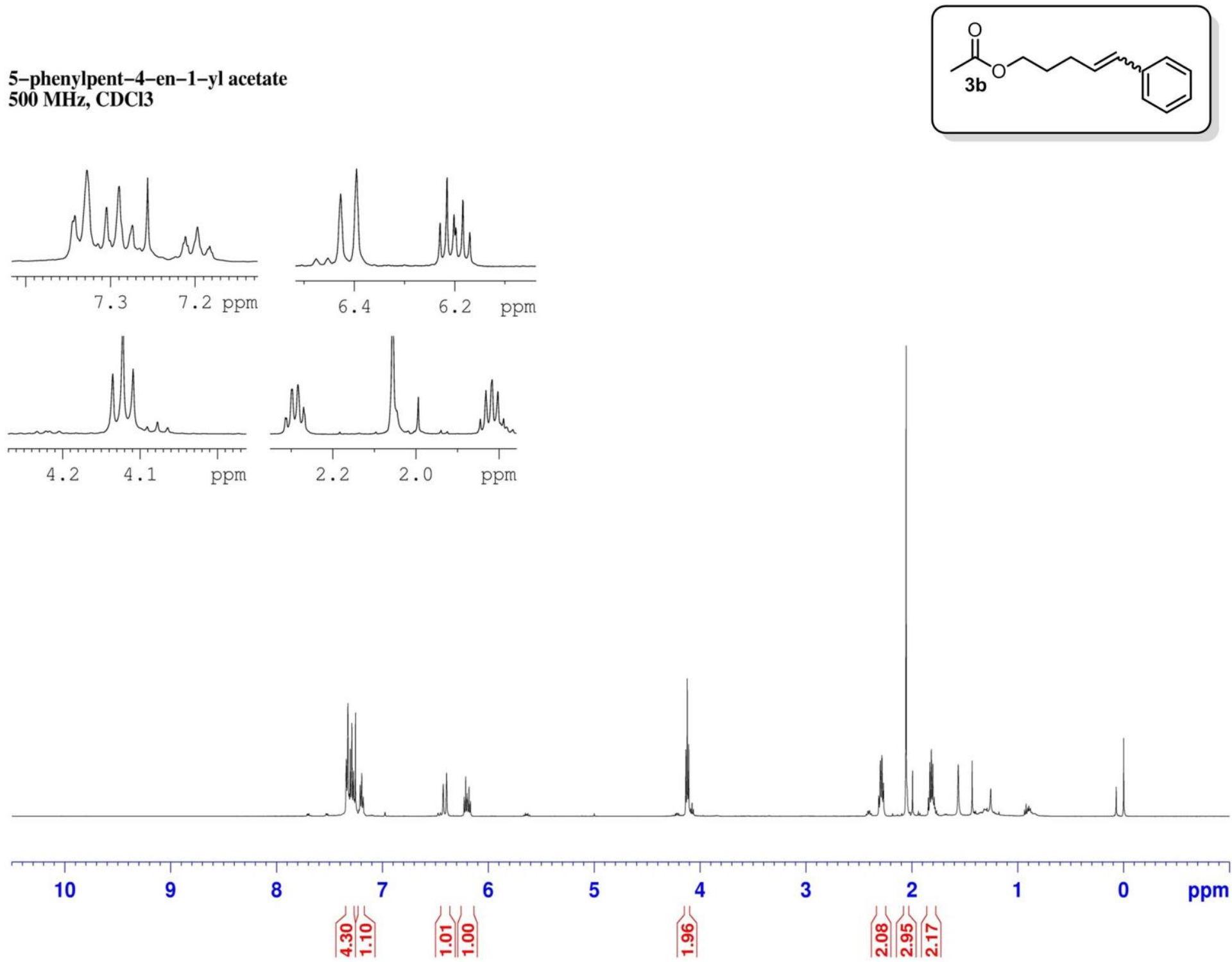
(E)-5-(4-methoxyphenyl)pent-4-en-1-yl acetate $500 \mathrm{MHz}, \mathrm{CDCl} 3$
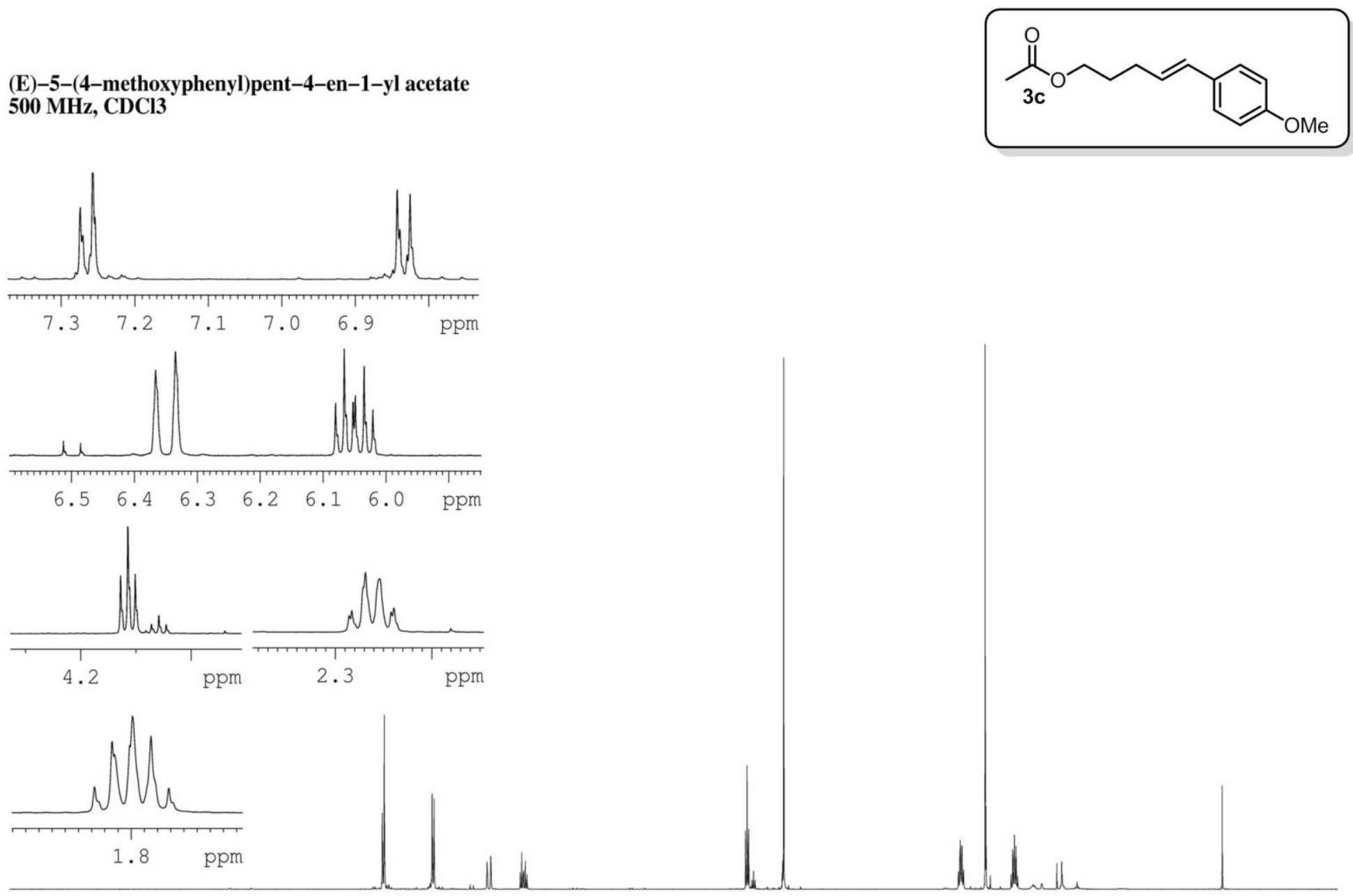

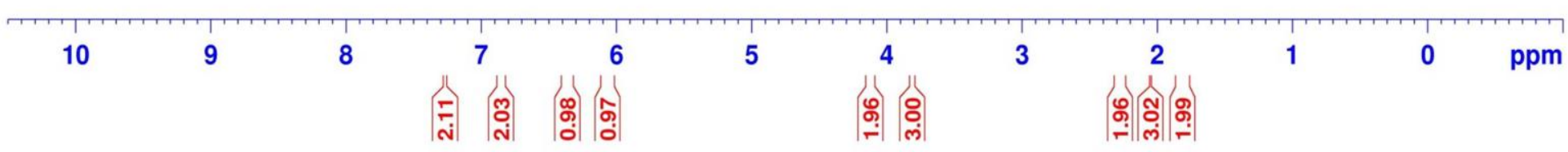


5-(4-chlorophenyl)pent-4-en-1-yl acetate $500 \mathrm{MHz}, \mathrm{CDCl} 3$
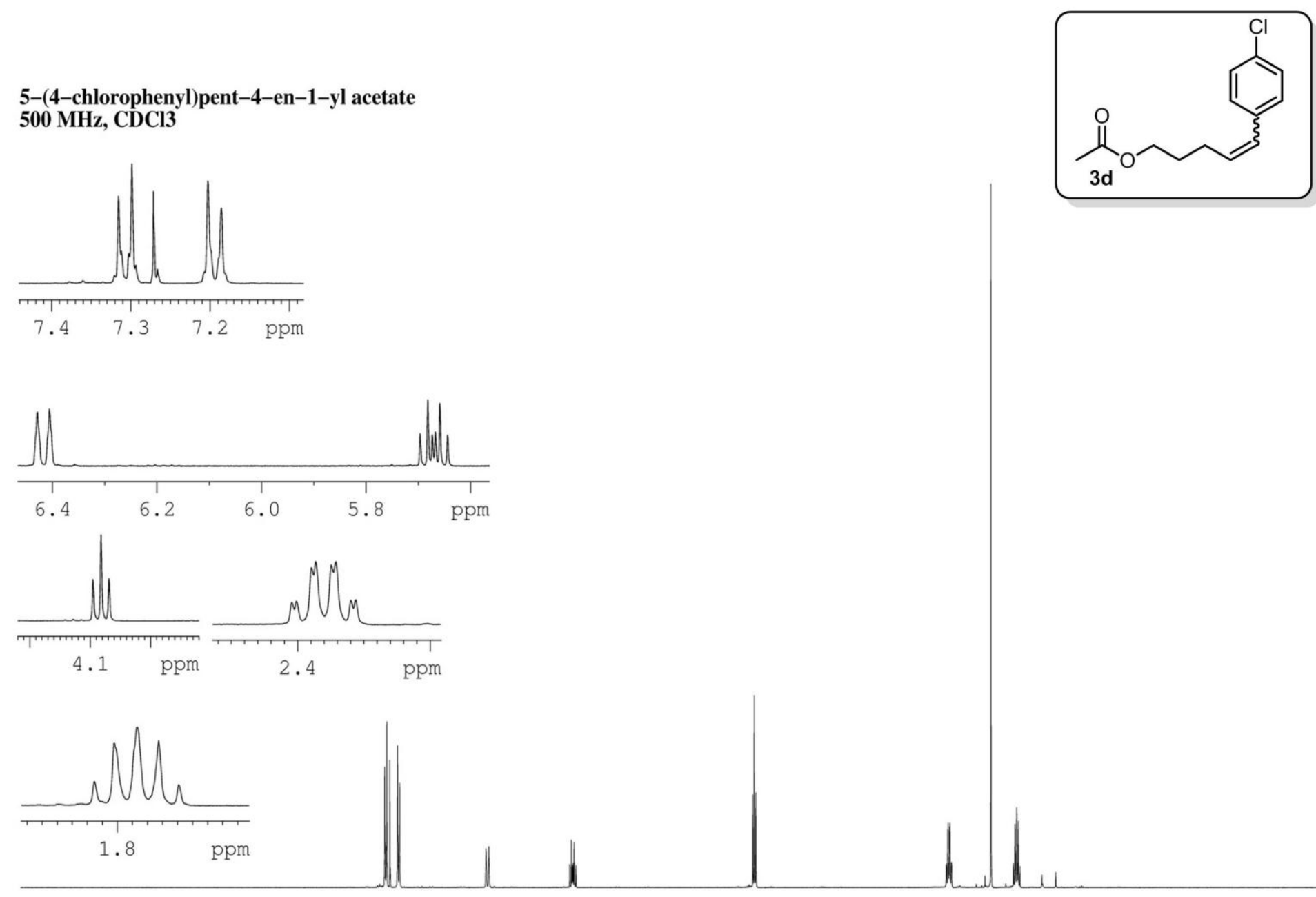

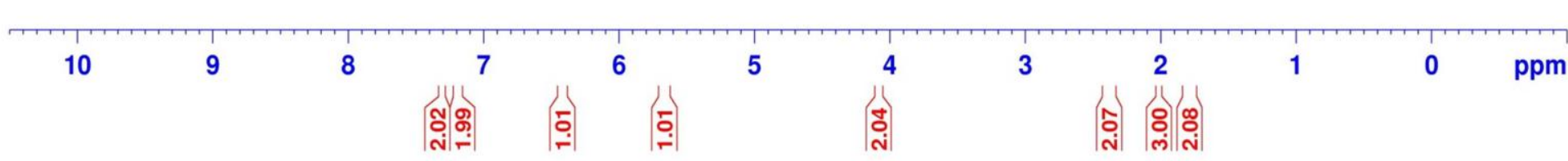


3-(1H-inden-2-yl)propyl acetate $500 \mathrm{MHz}, \mathrm{CDCl} 3$
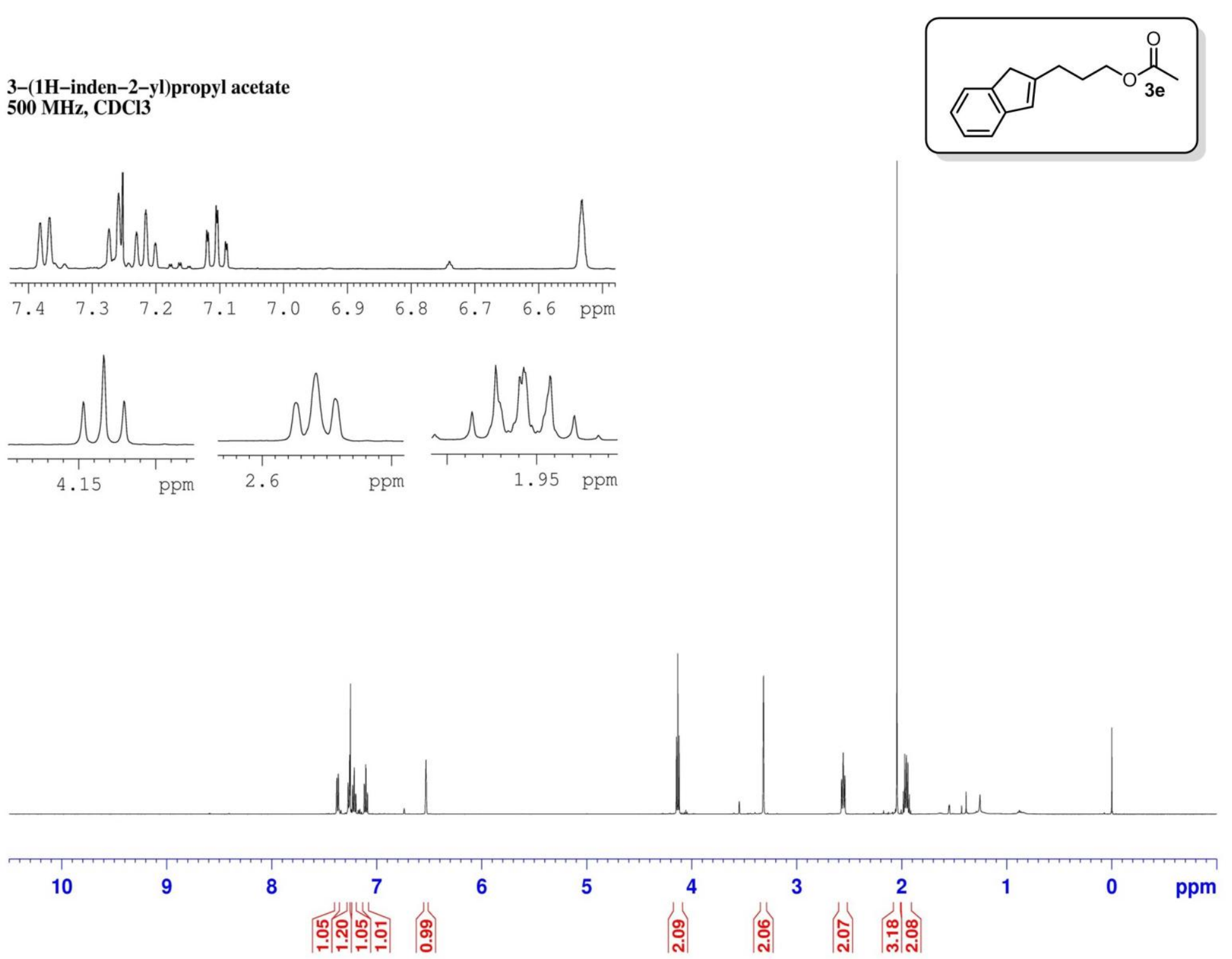
(Z)-ethyl 6-acetoxyhex-2-enoate $500 \mathrm{MHz}, \mathrm{CDCl} 3$
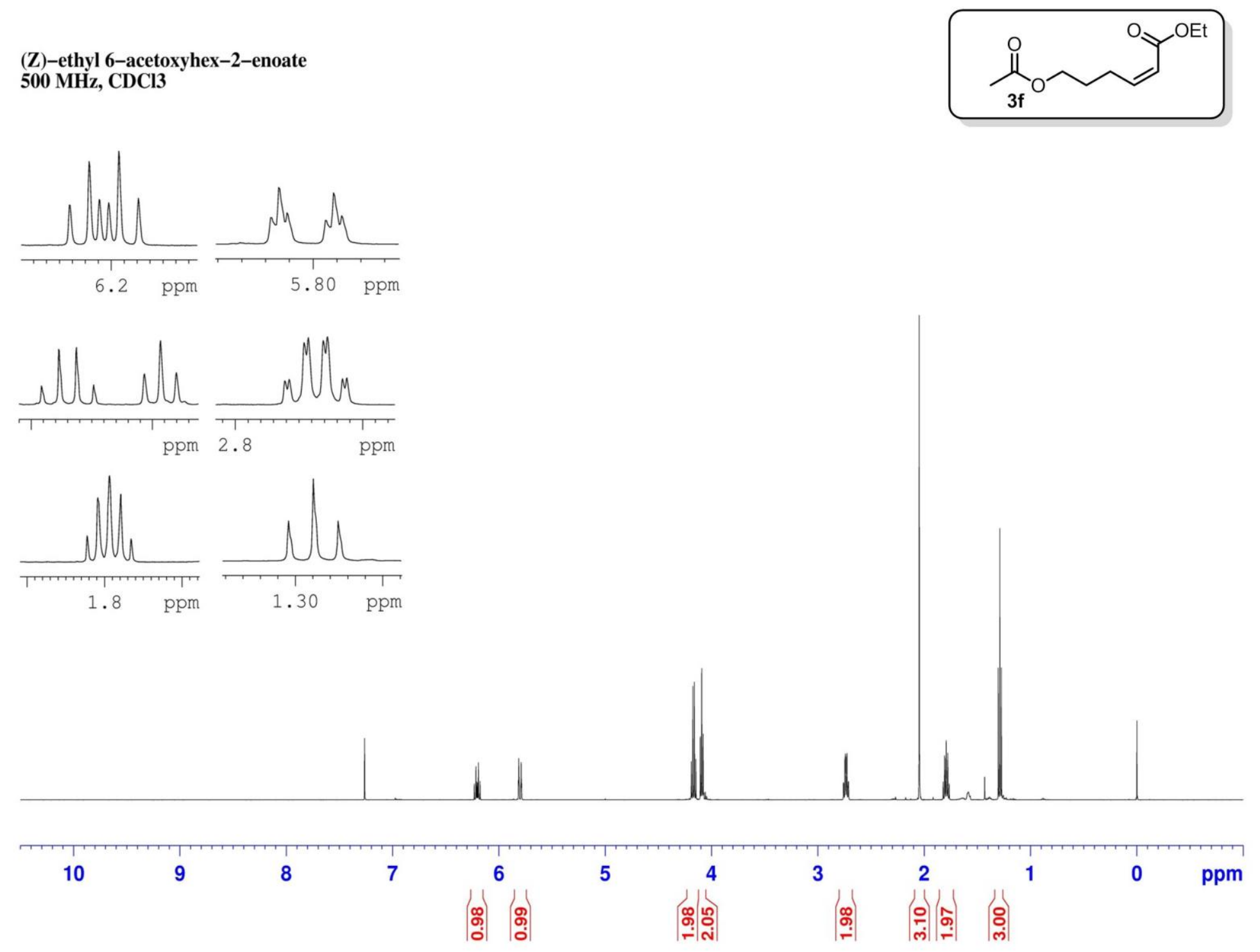
(E)-3-(cyclooct-1-en-1-yl)propyl acetate

$500 \mathrm{MHz}, \mathrm{CDCl} 3$
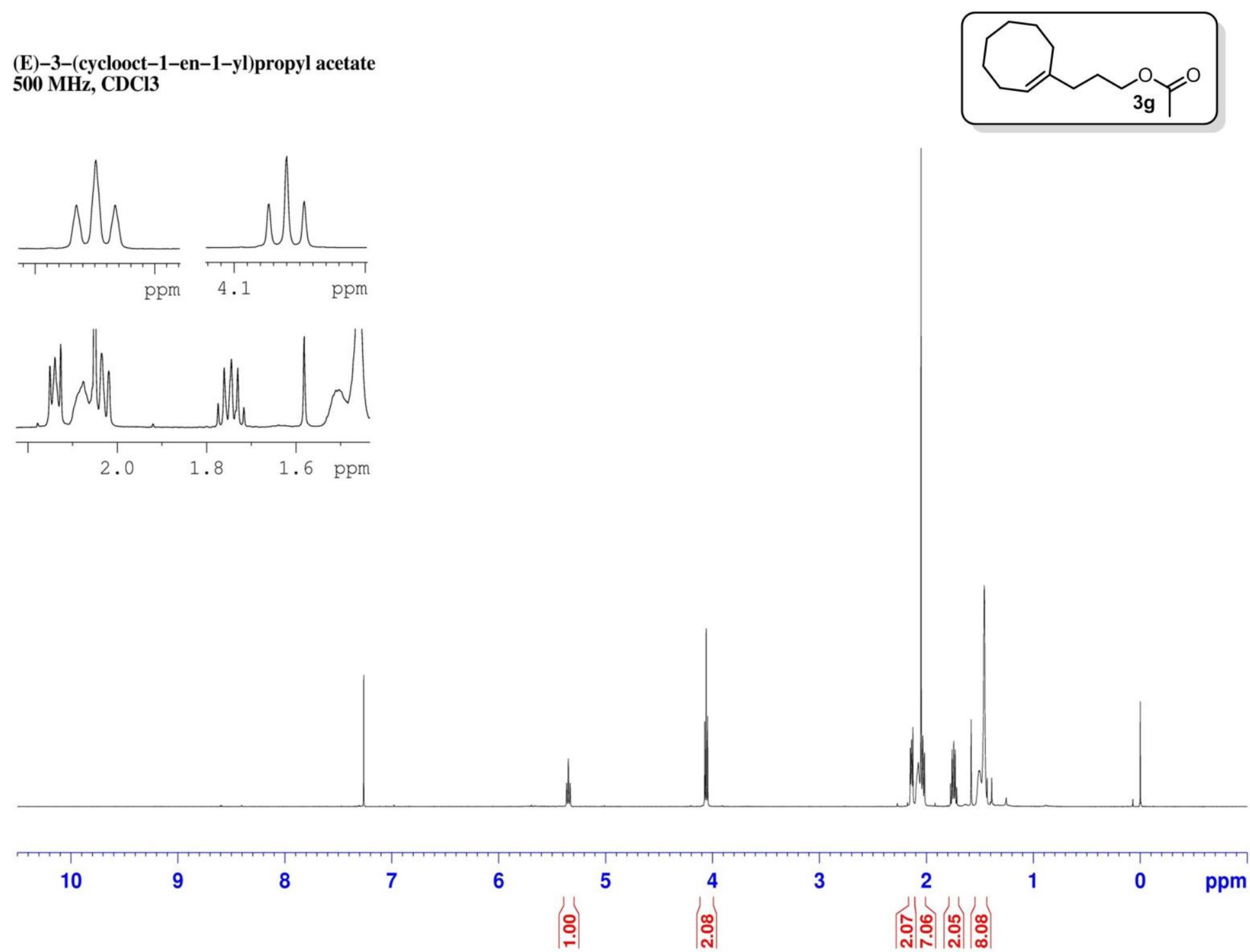
4-cyclohexylidenebutyl acetate $500 \mathrm{MHz}, \mathrm{CDCl} 3$
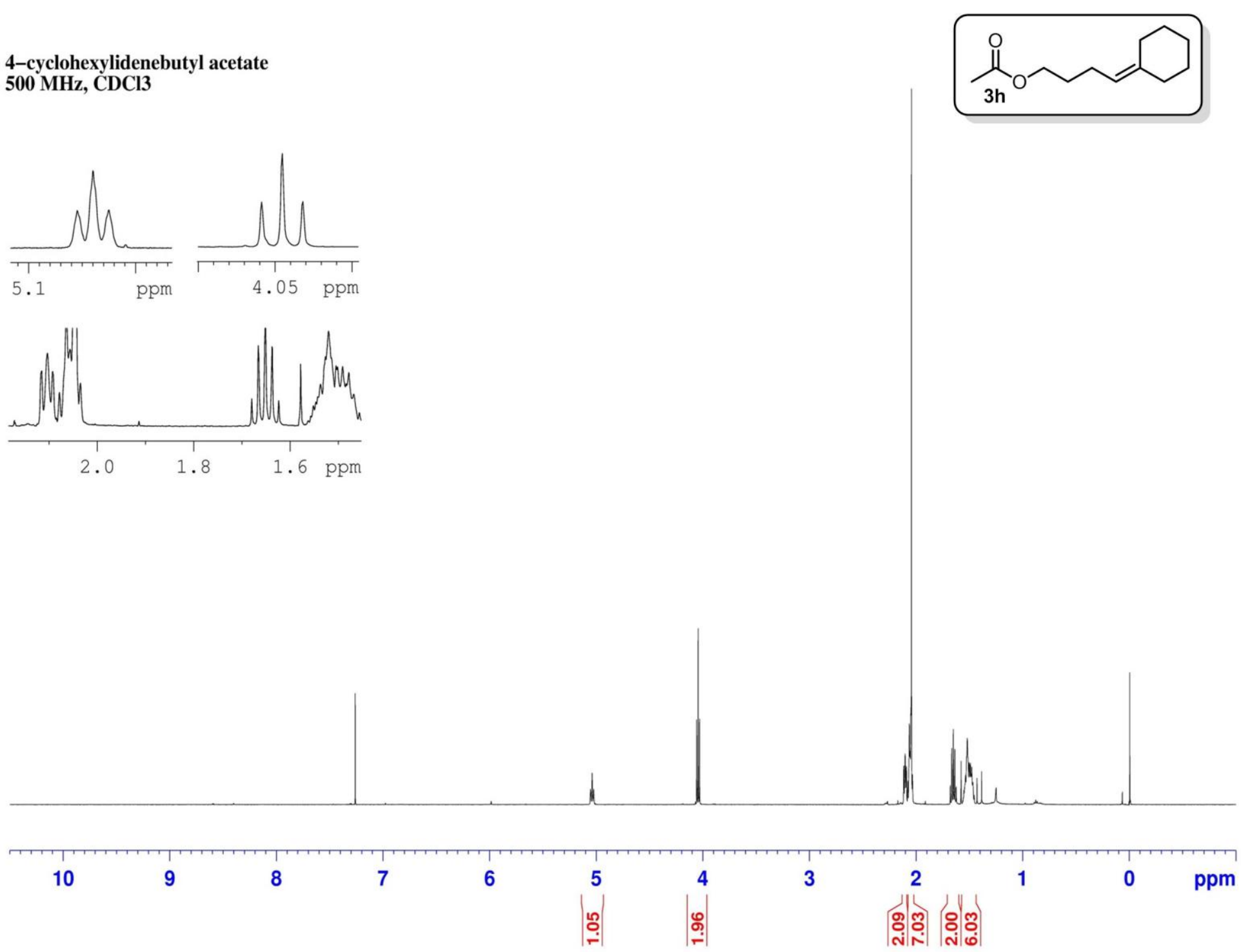
5-methylhex-4-en-1-yl acetate

$500 \mathrm{MHz}, \mathrm{CDCl} 3$
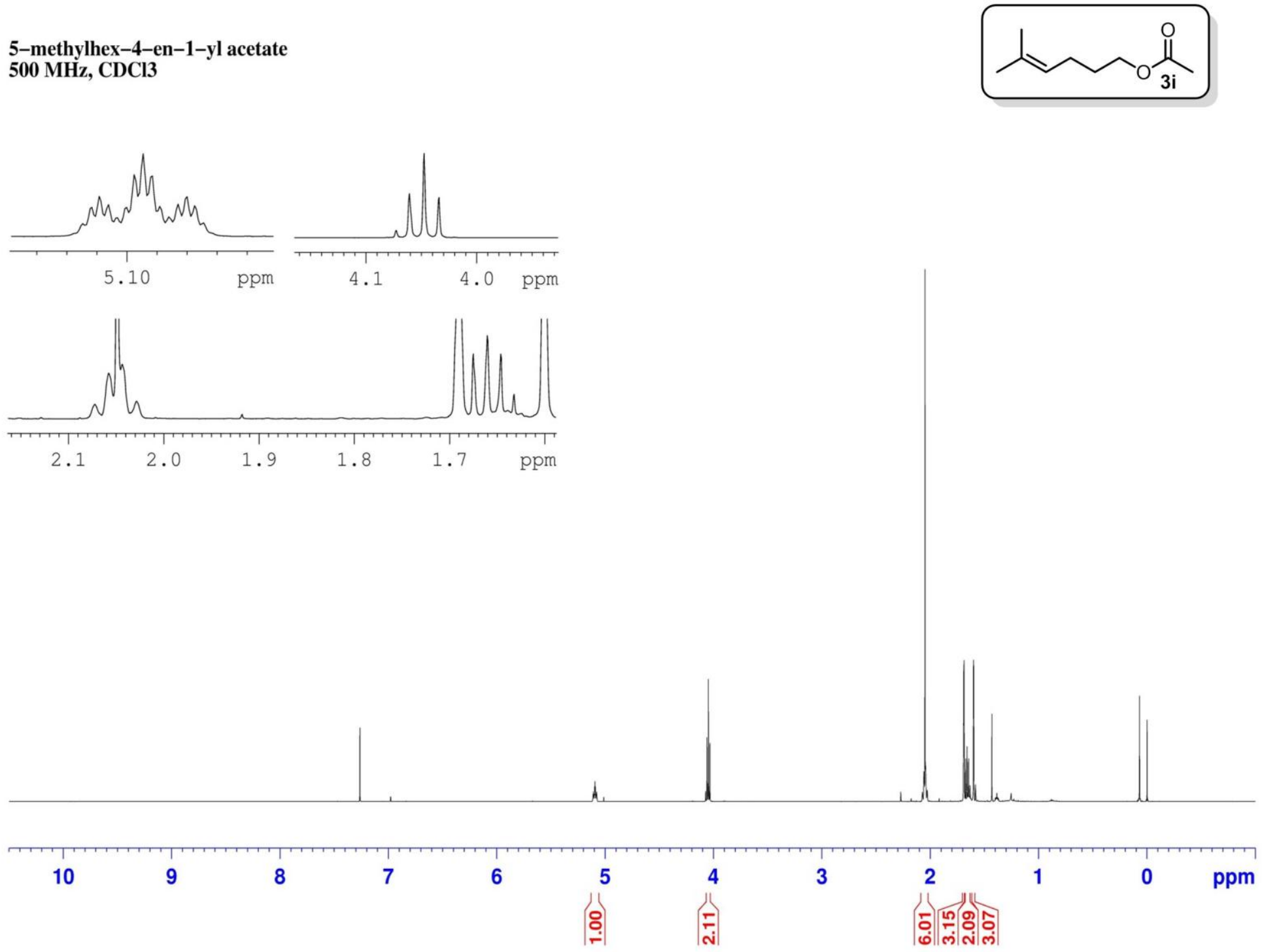
(Z)-6-((tert-butyldimethylsilyl)oxy)hex-4-en-1-yl acetate $500 \mathrm{MHz}, \mathrm{CDCl} 3$
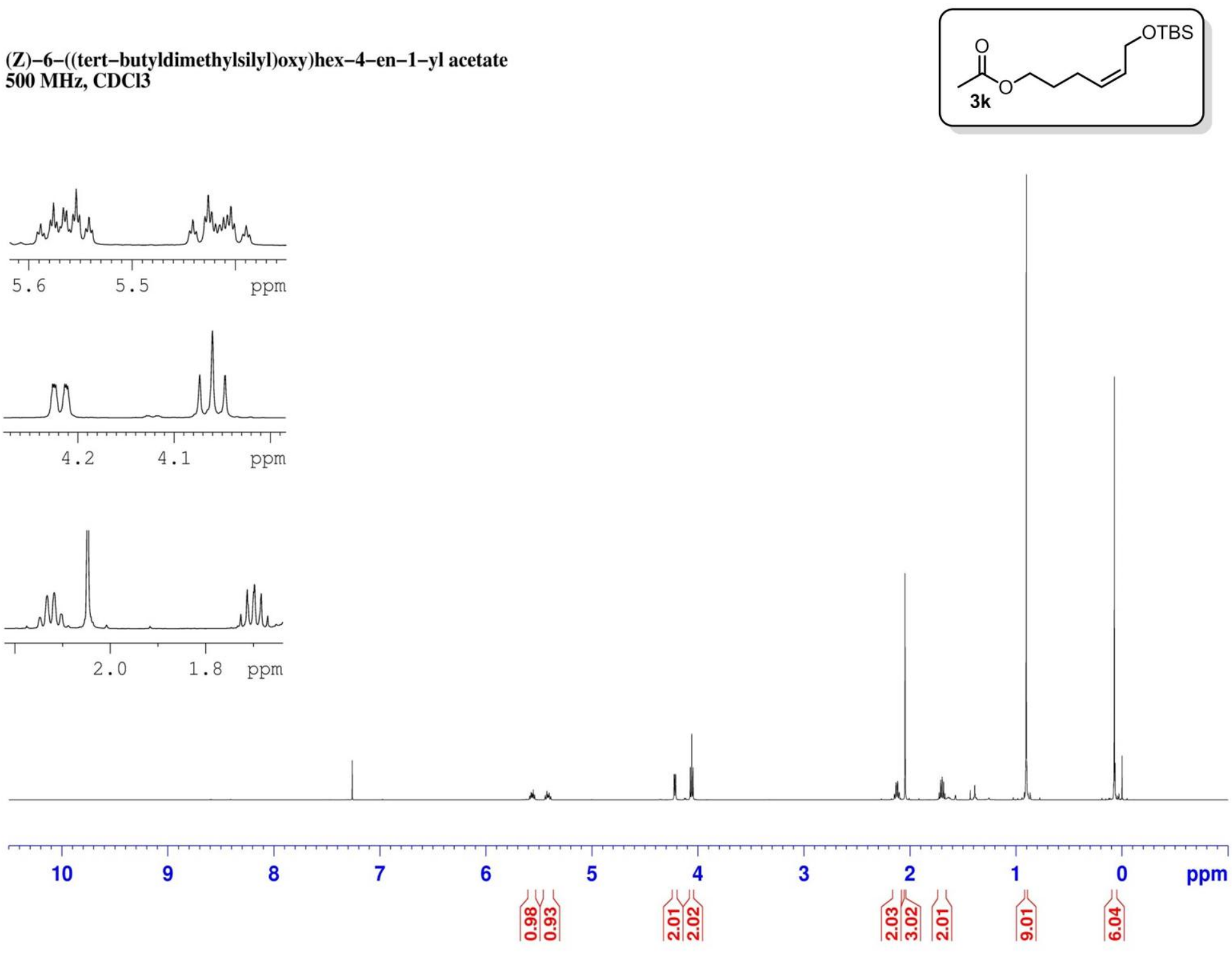
(E)-oct-1-en-1-ylcyclopentane
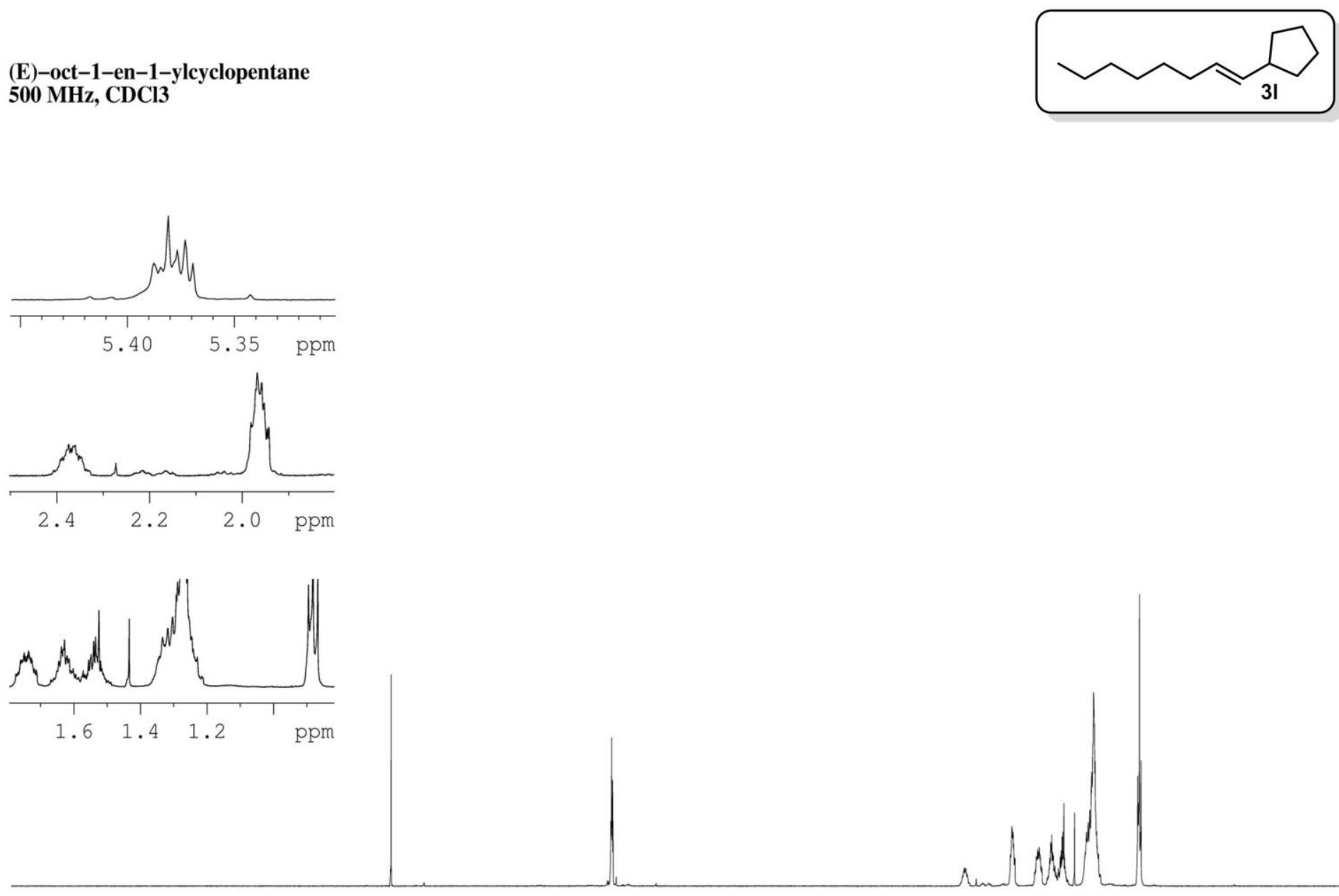

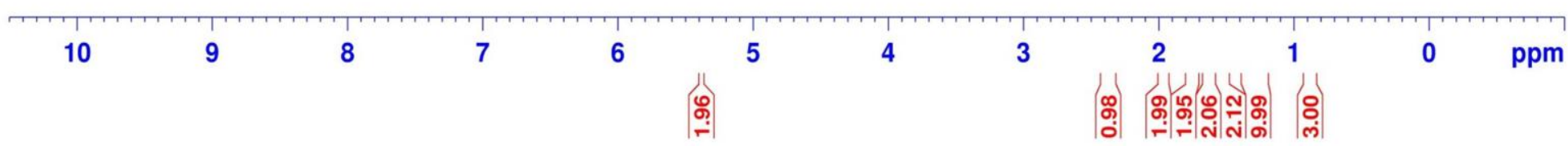


(E)-oct-1-en-1-ylcyclohexane

$500 \mathrm{MHz}, \mathrm{CDCl} 3$
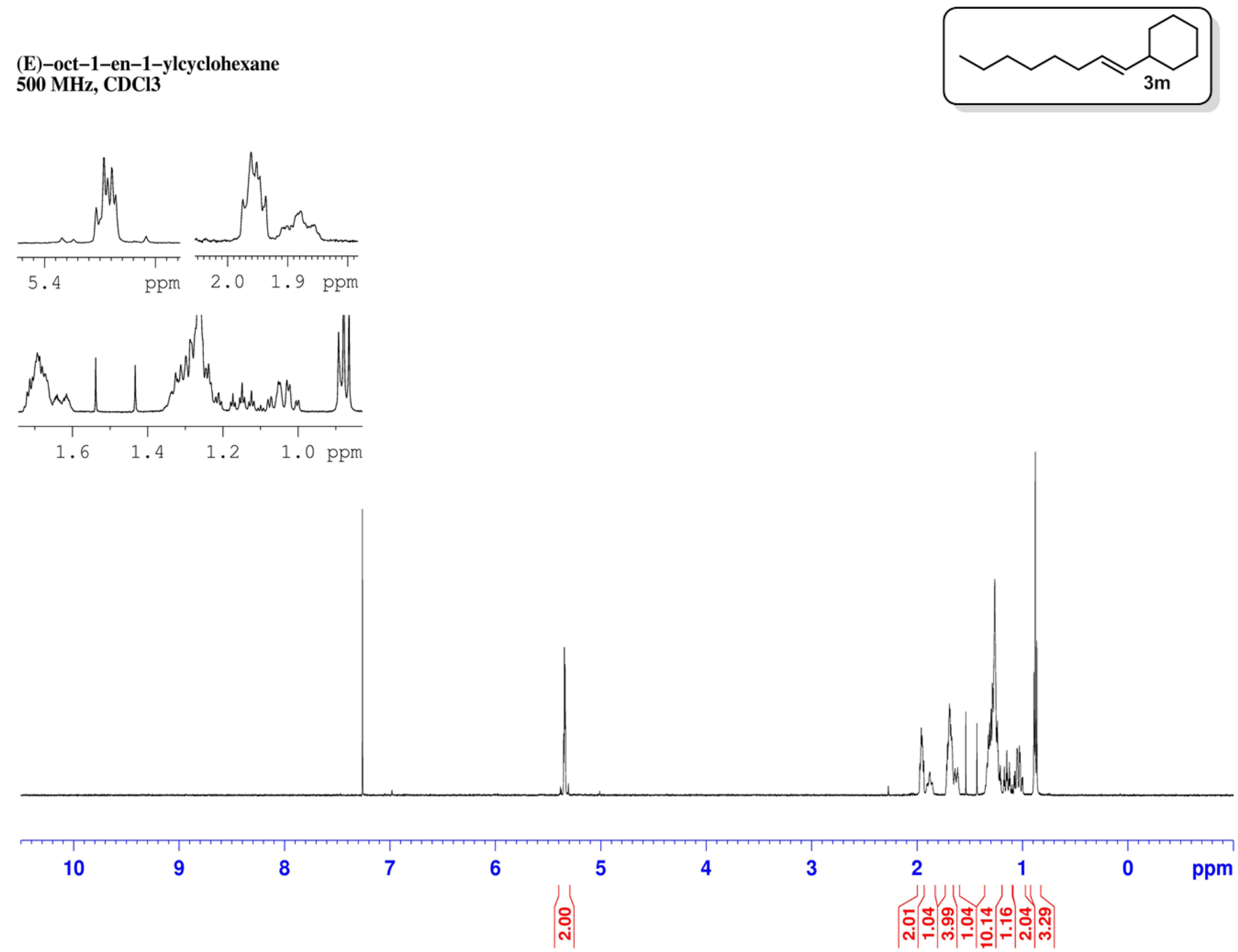
(E)-2-(oct-1-en-1-yl)bicyclo[2.2.1]heptane
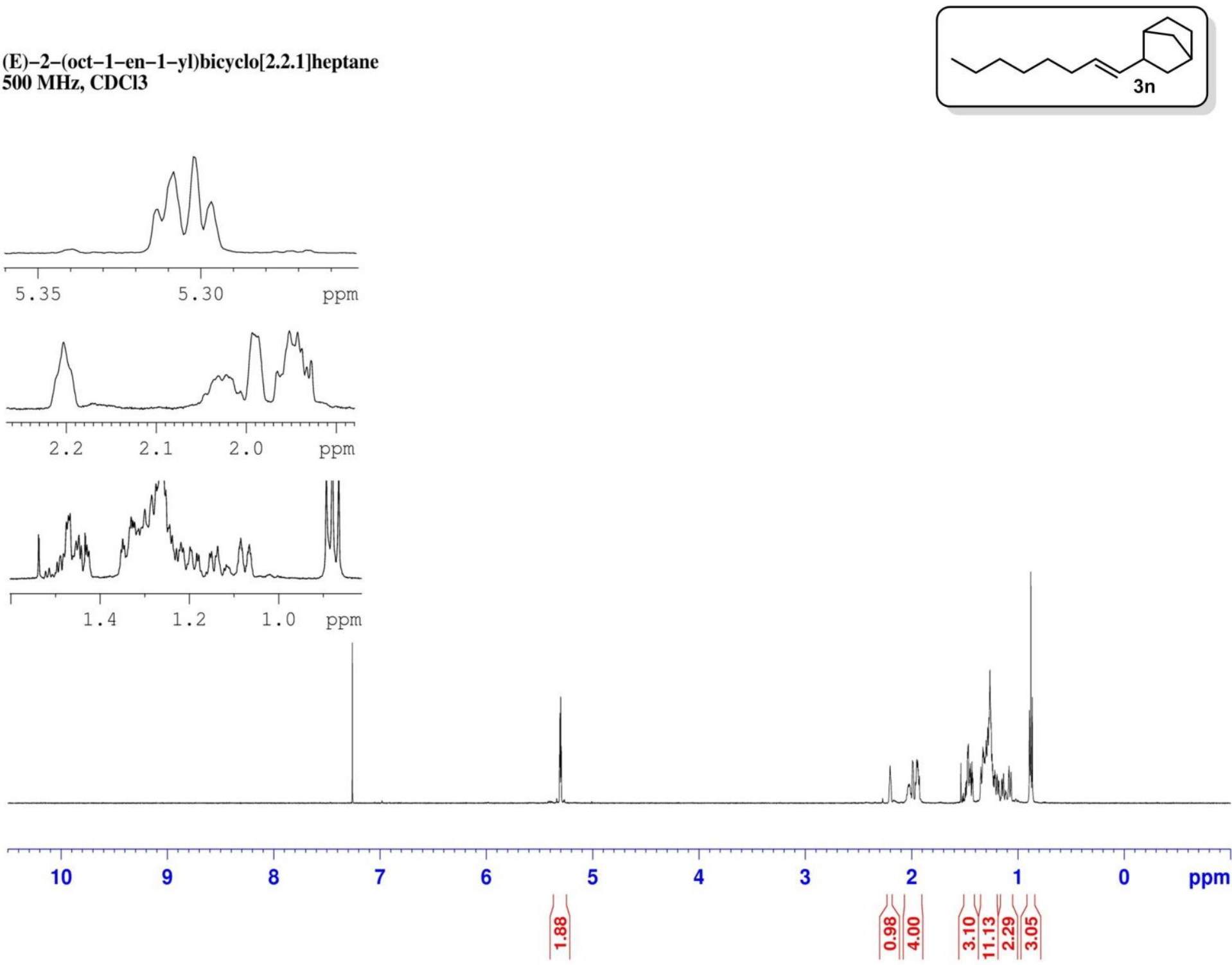
(E)-non-2-en-1-ylbenzene $500 \mathrm{MHz}, \mathrm{CDCl} 3$
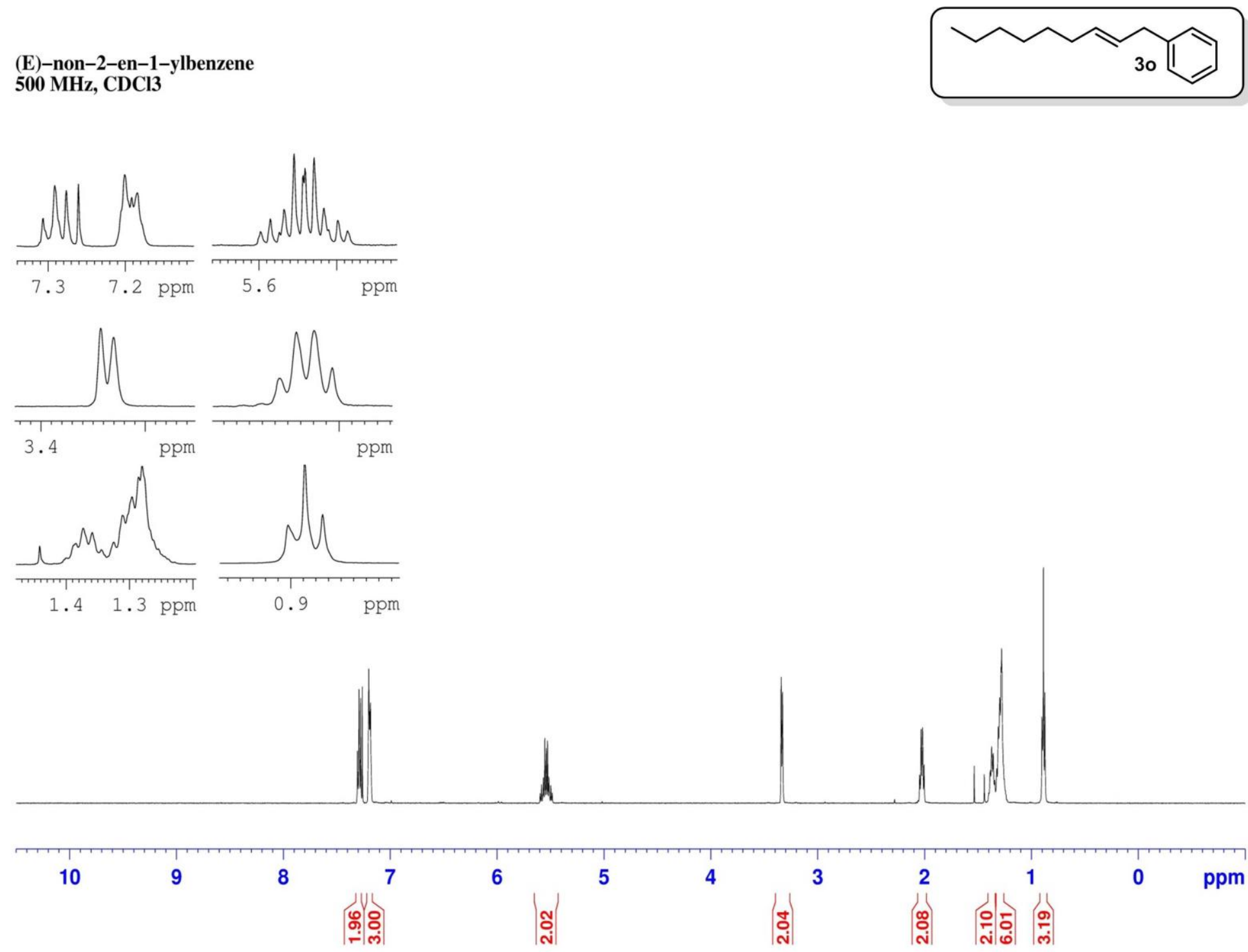
(E)-undeca-1,4-diene $500 \mathrm{MHz}, \mathrm{CDCl} 3$

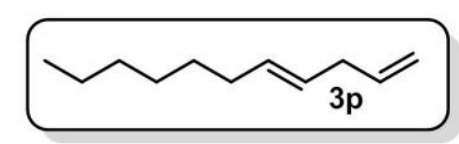

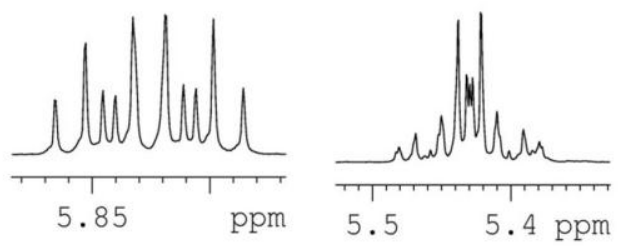
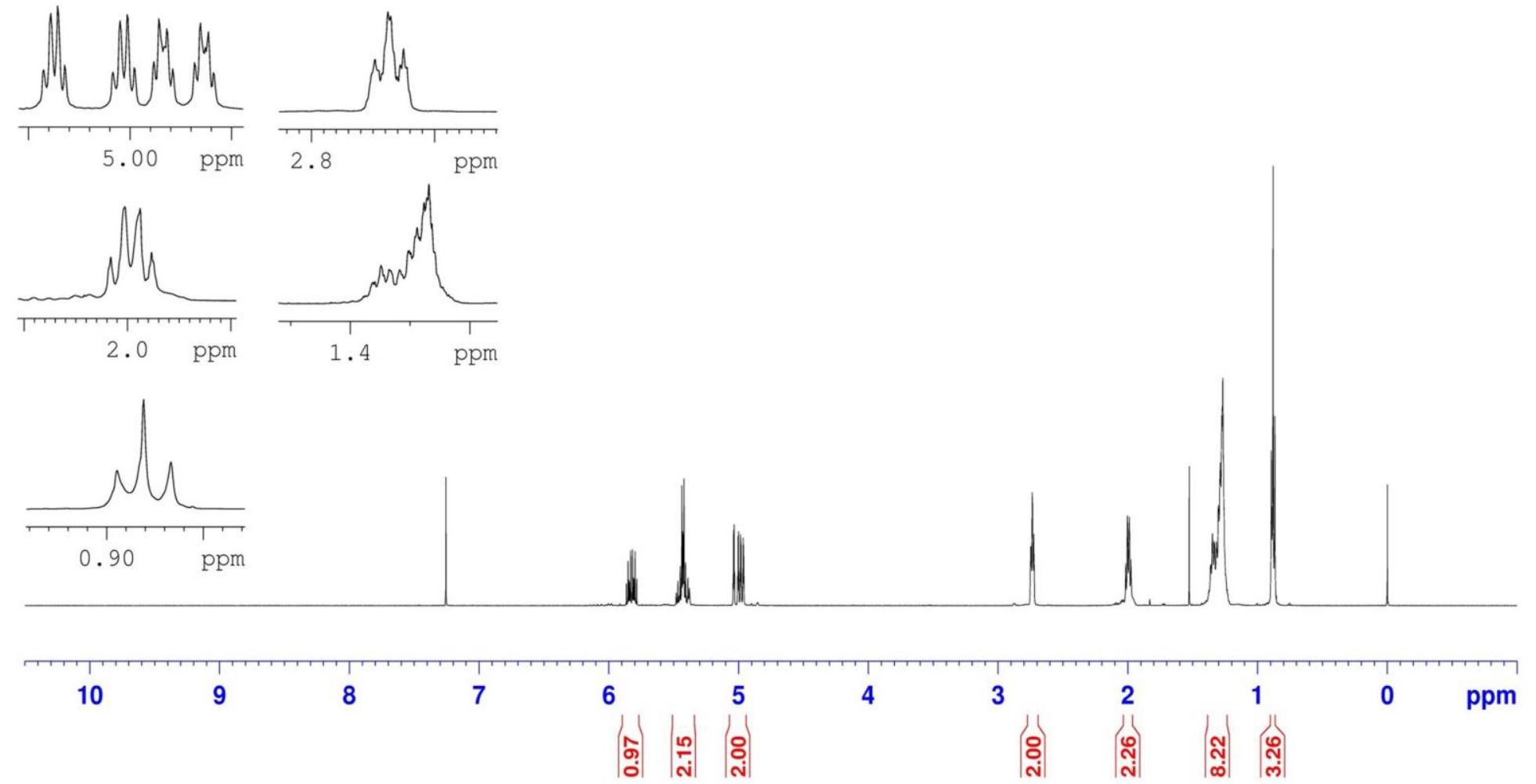
(E)-2-methylundec-4-ene $500 \mathrm{MHz}, \mathrm{CDCl} 3$
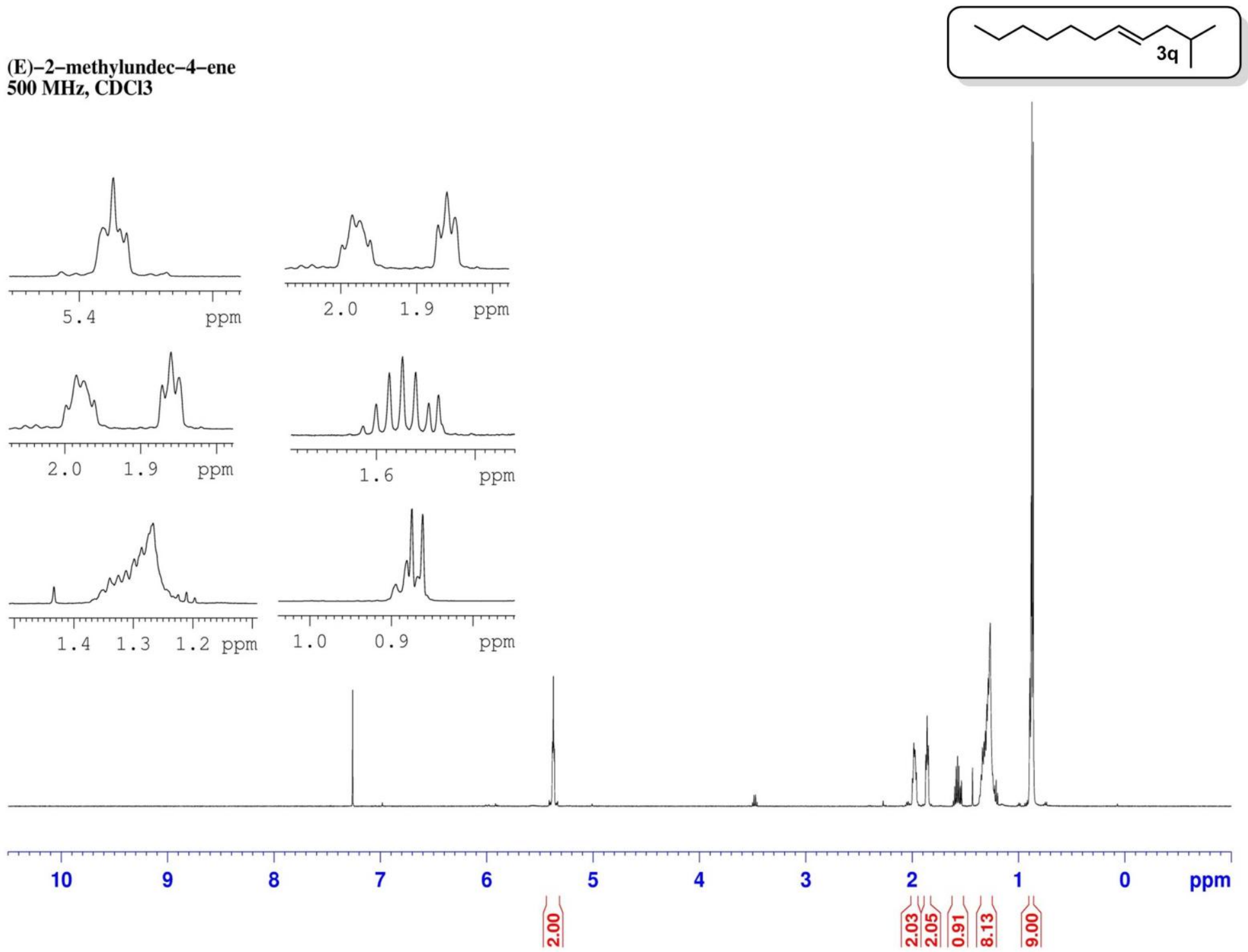
(E)-4-(dec-3-en-1-yl)cyclohex-1-ene $500 \mathrm{MHz}, \mathrm{CDCl} 3$
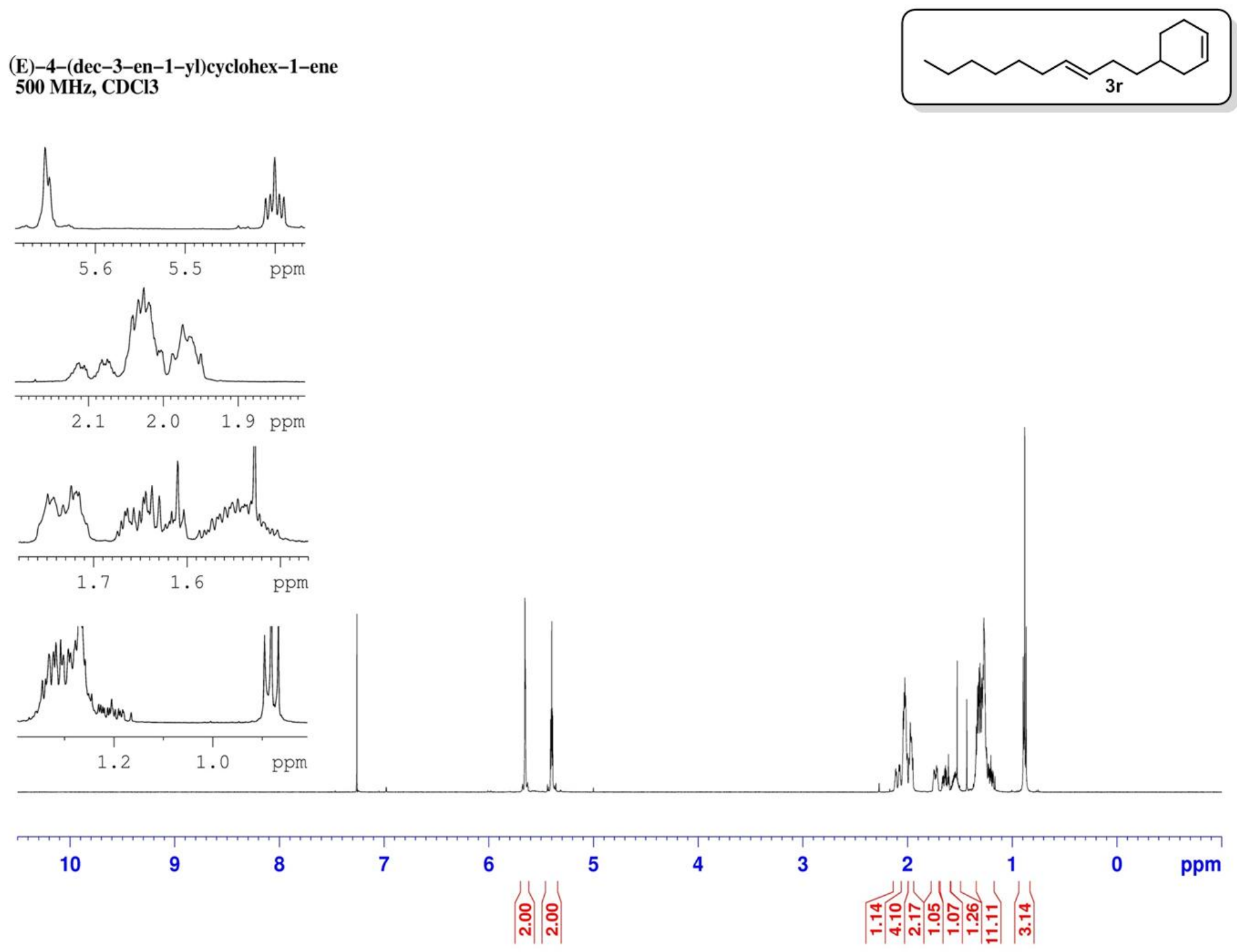
(E)-tetradec-7-ene

$500 \mathrm{MHz}, \mathrm{CDCl} 3$
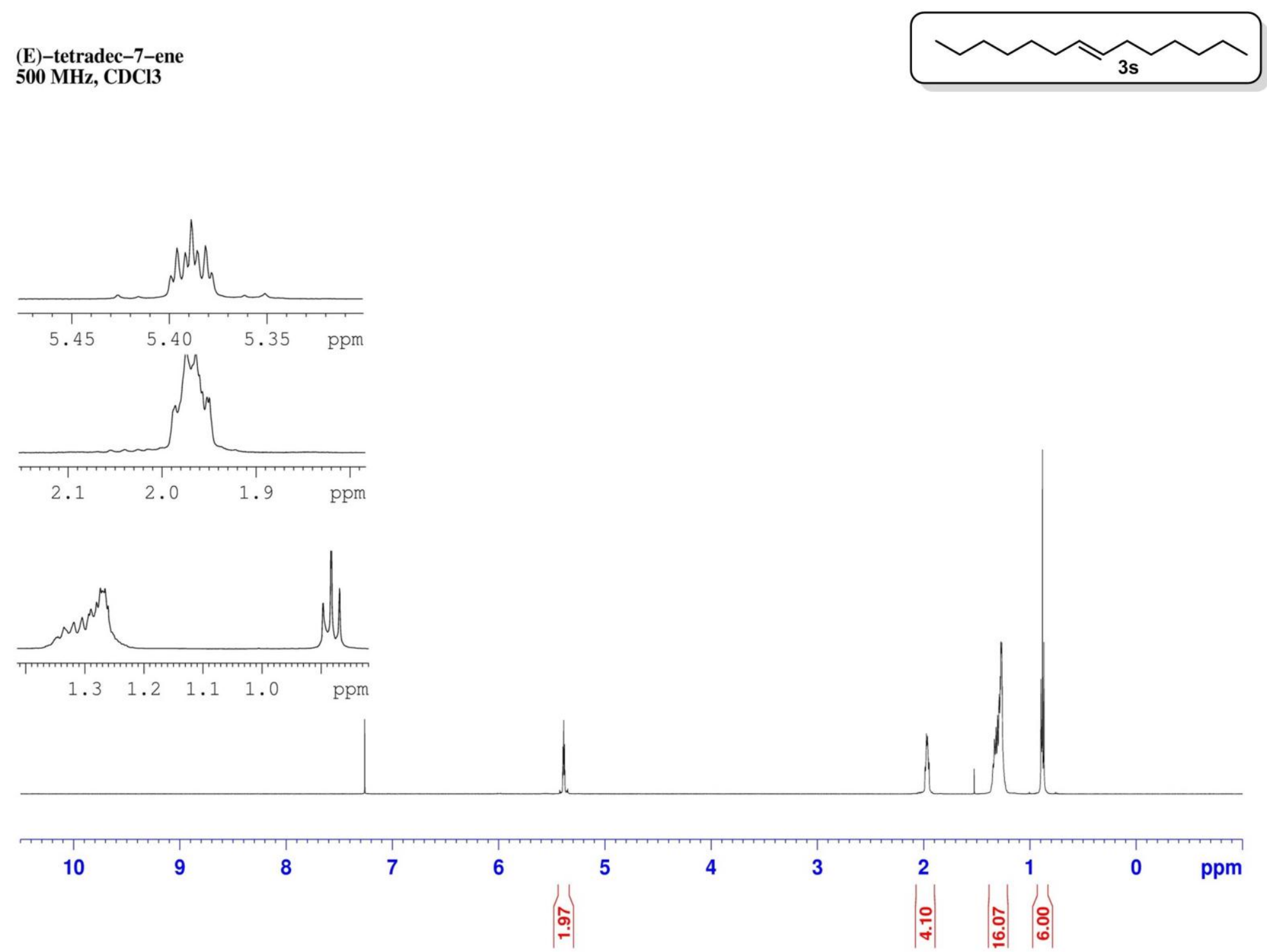
(E)-1-methoxyundec-4-ene $500 \mathrm{MHz}, \mathrm{CDCl} 3$
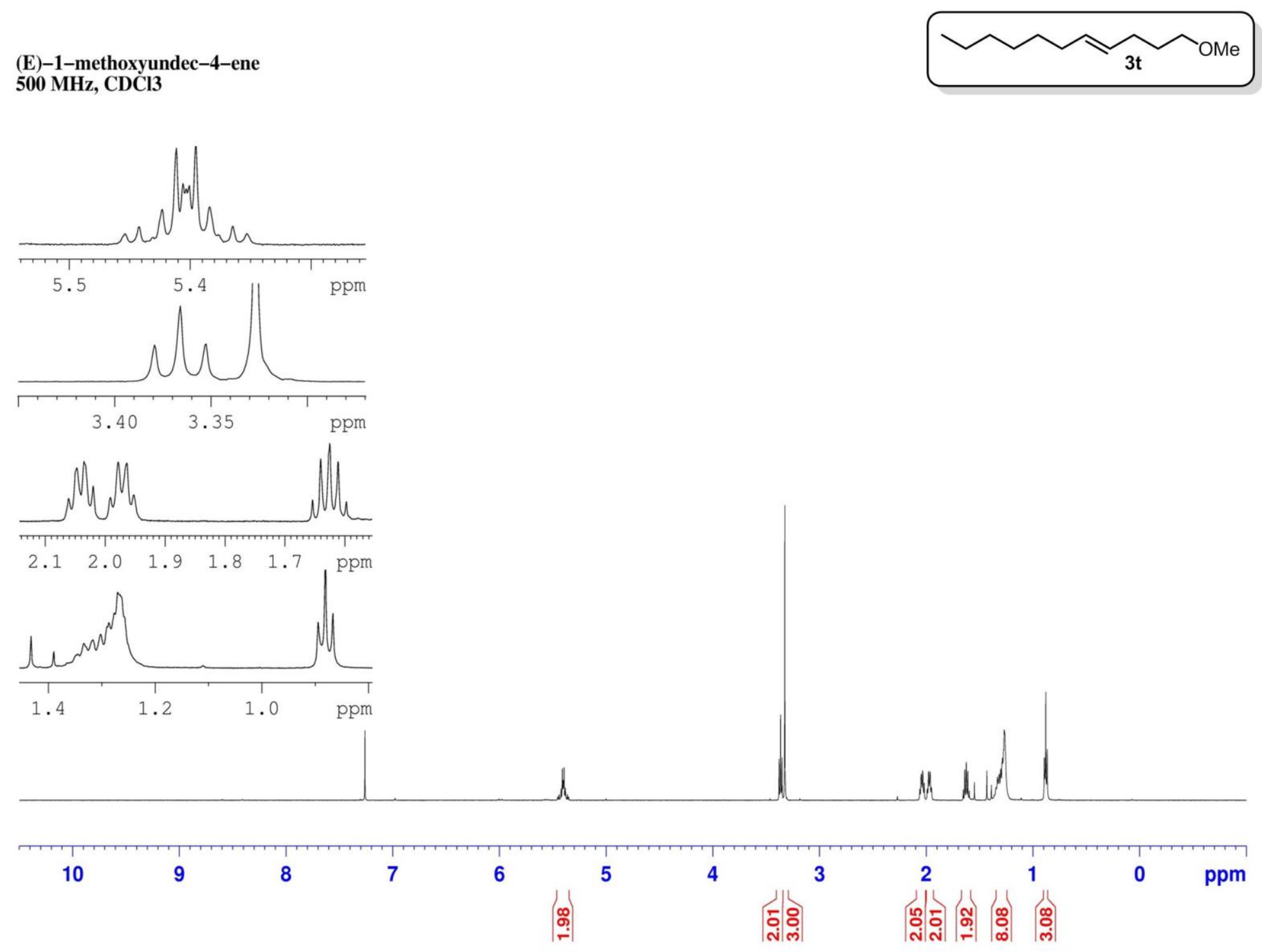
(E)-N-(undec-4-en-1-yl)acetamide
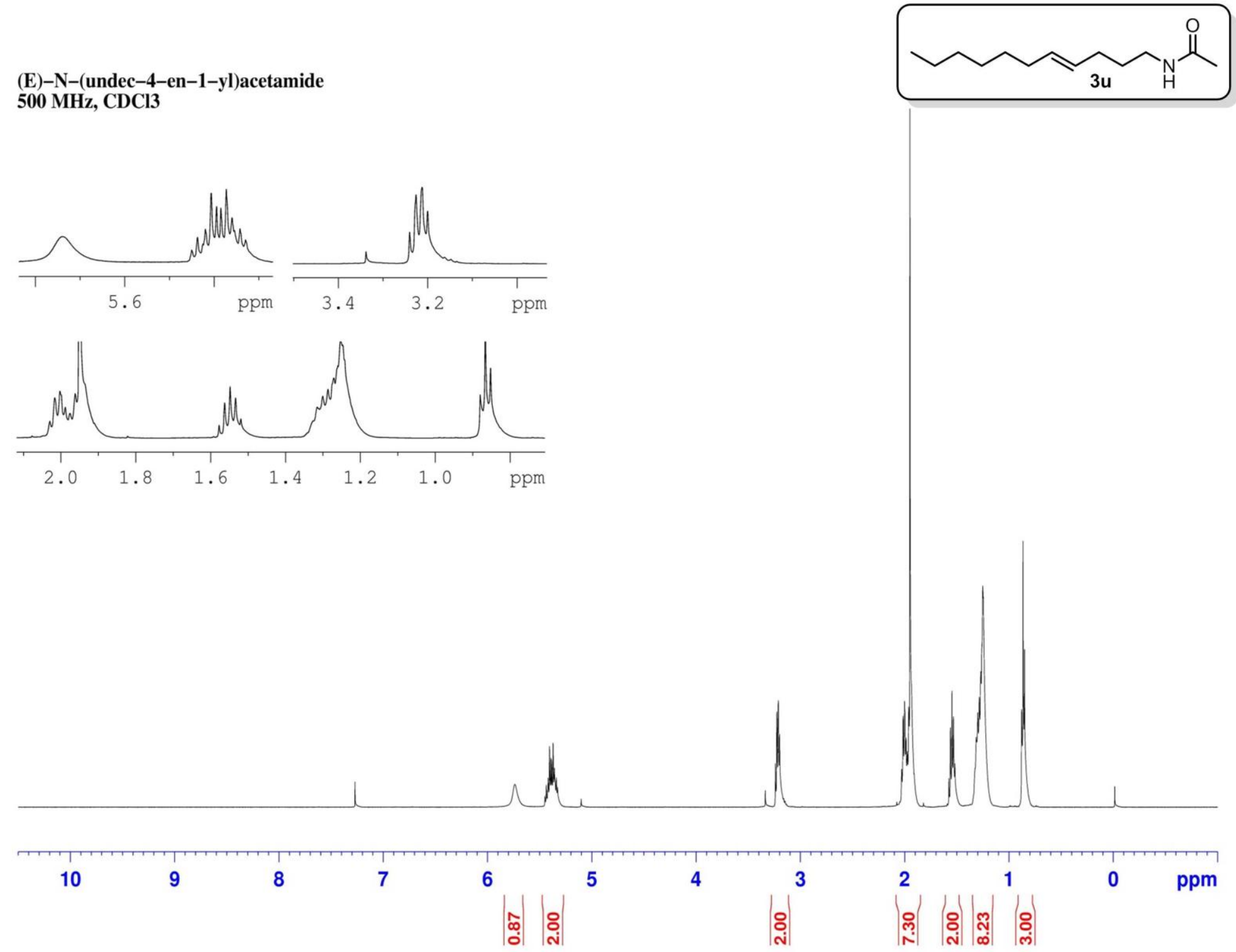
(E)-2-(dec-3-en-1-yl)pyridine $500 \mathrm{MHz}, \mathrm{CDCl} 3$
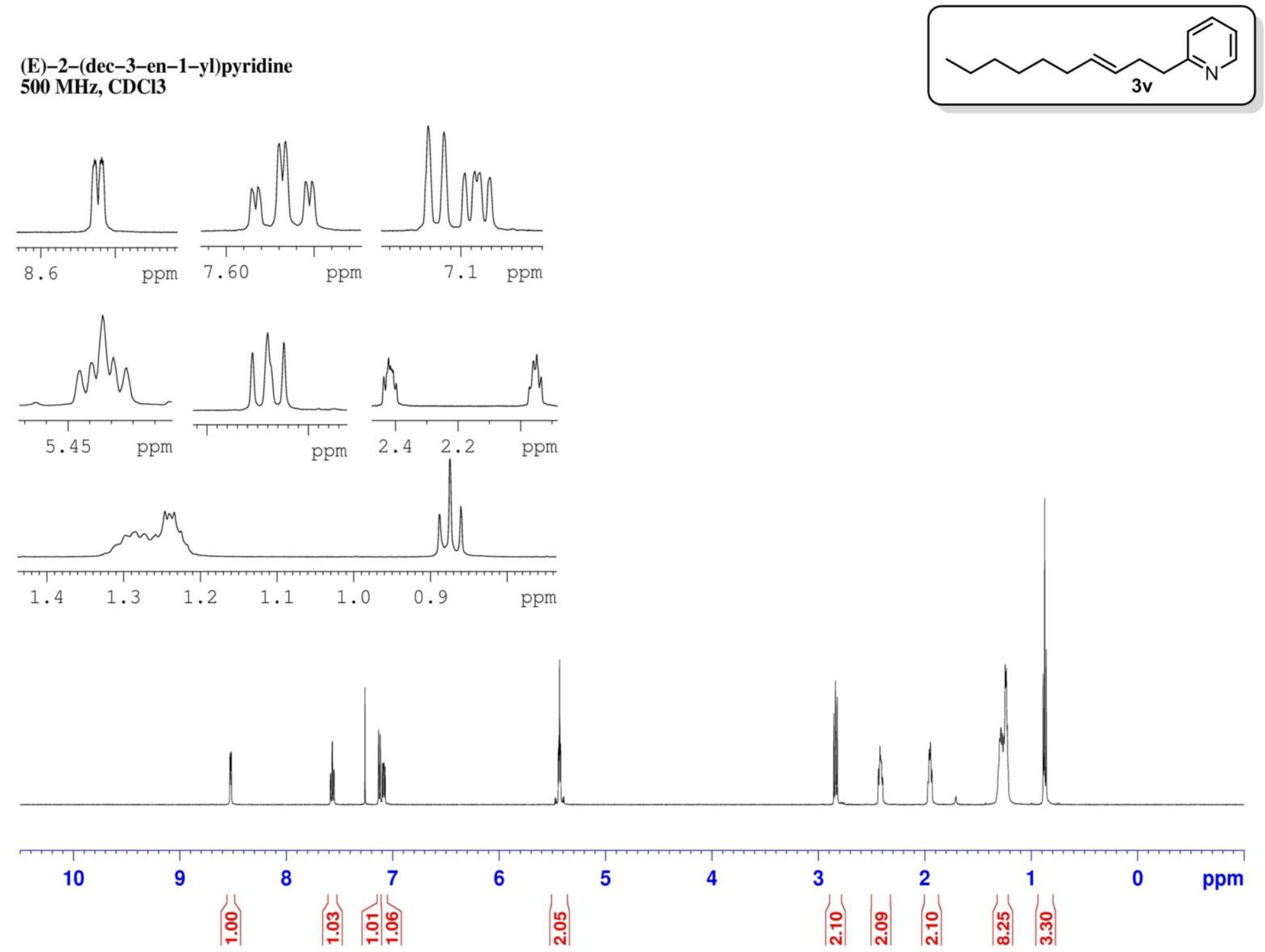
(E)-undec-4-en-1-amine

$500 \mathrm{MHz}, \mathrm{CDCl} 3$
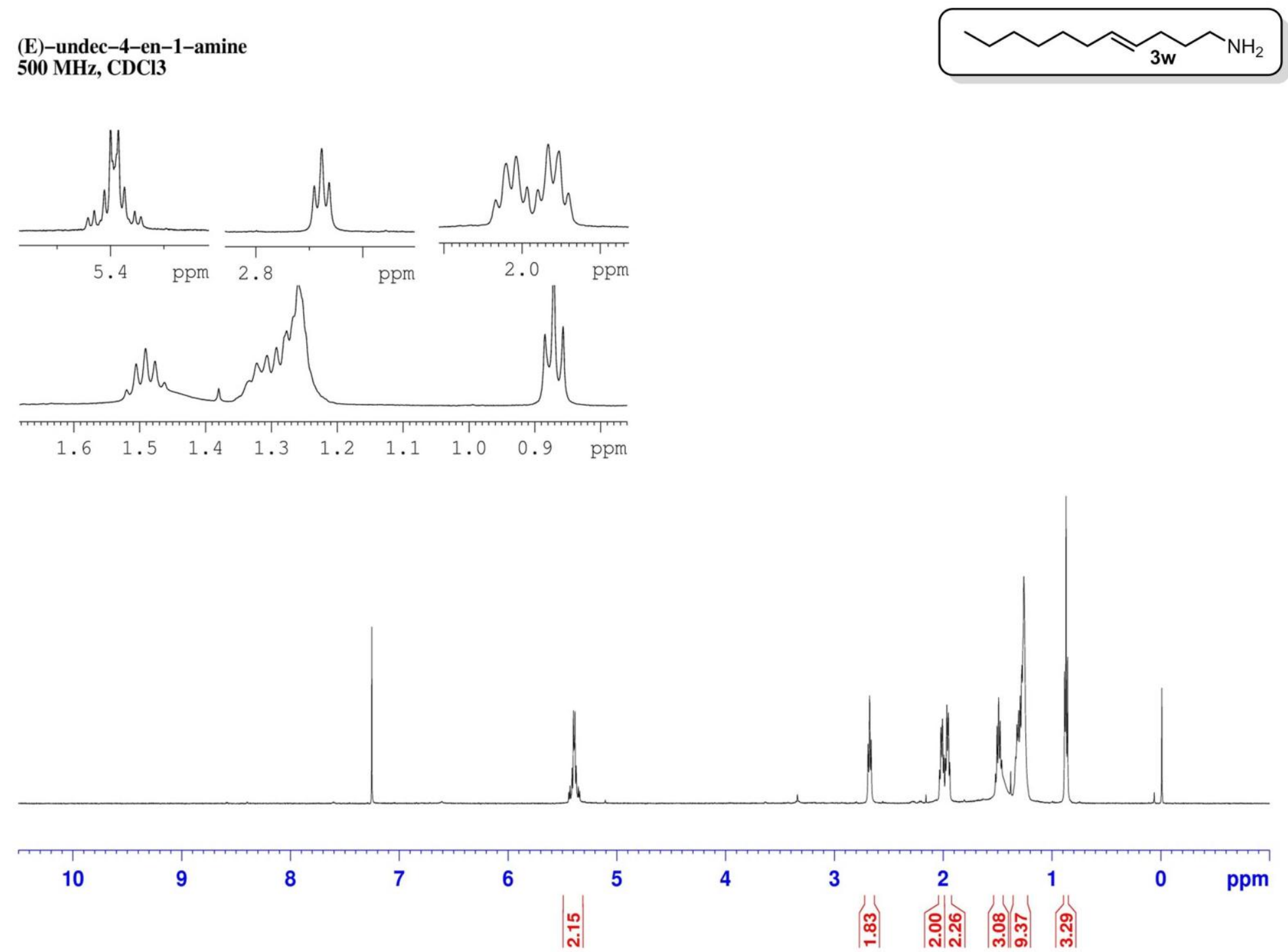
(E)-1-benzylcyclooct-1-ene $125 \mathrm{MHz}, \mathrm{CDCl} 3$
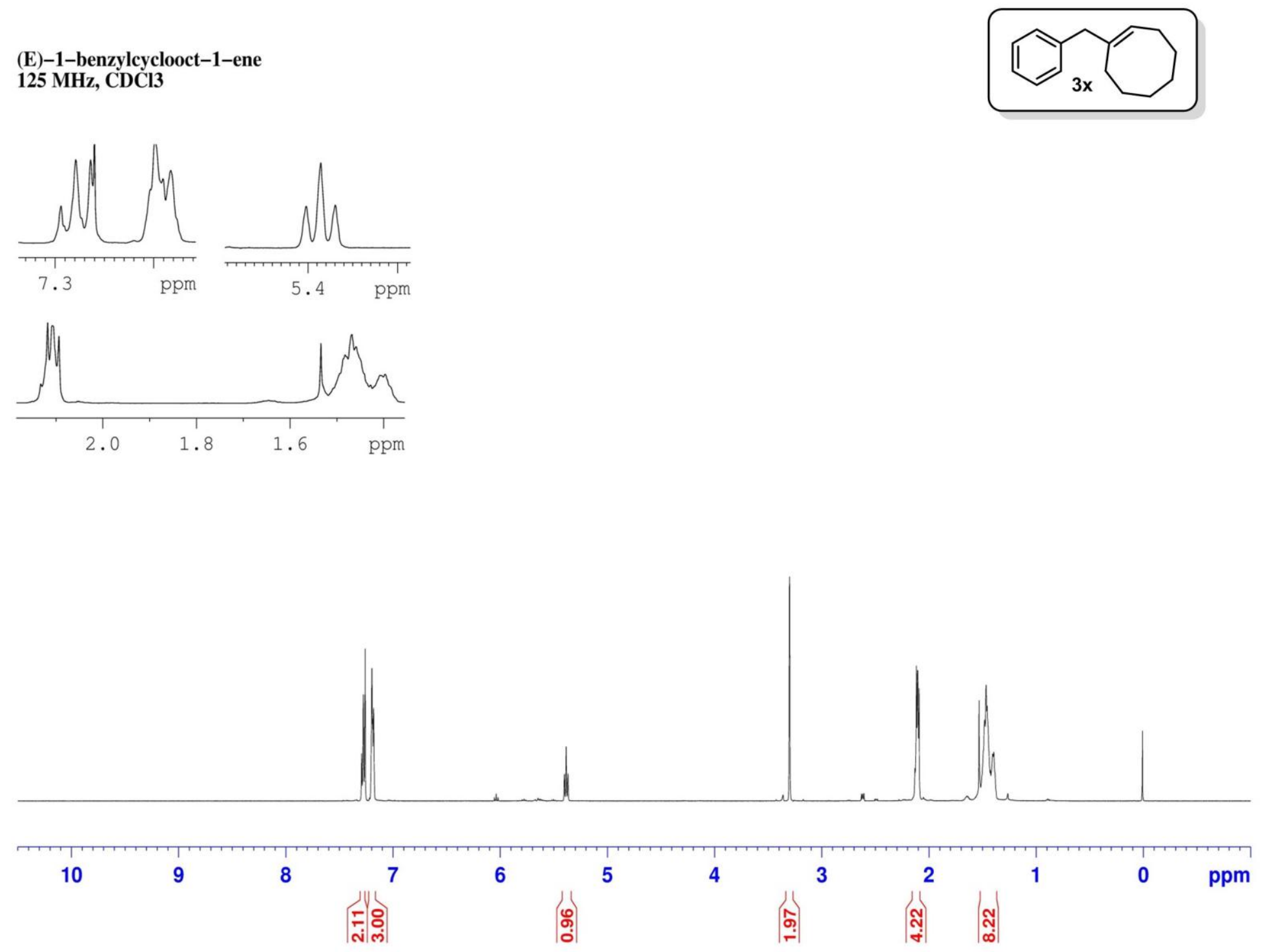
(E)-1-(2-(cyclohex-3-en-1-yl)ethyl)cyclooct-1-ene $500 \mathrm{MHz}, \mathrm{CDCl} 3$
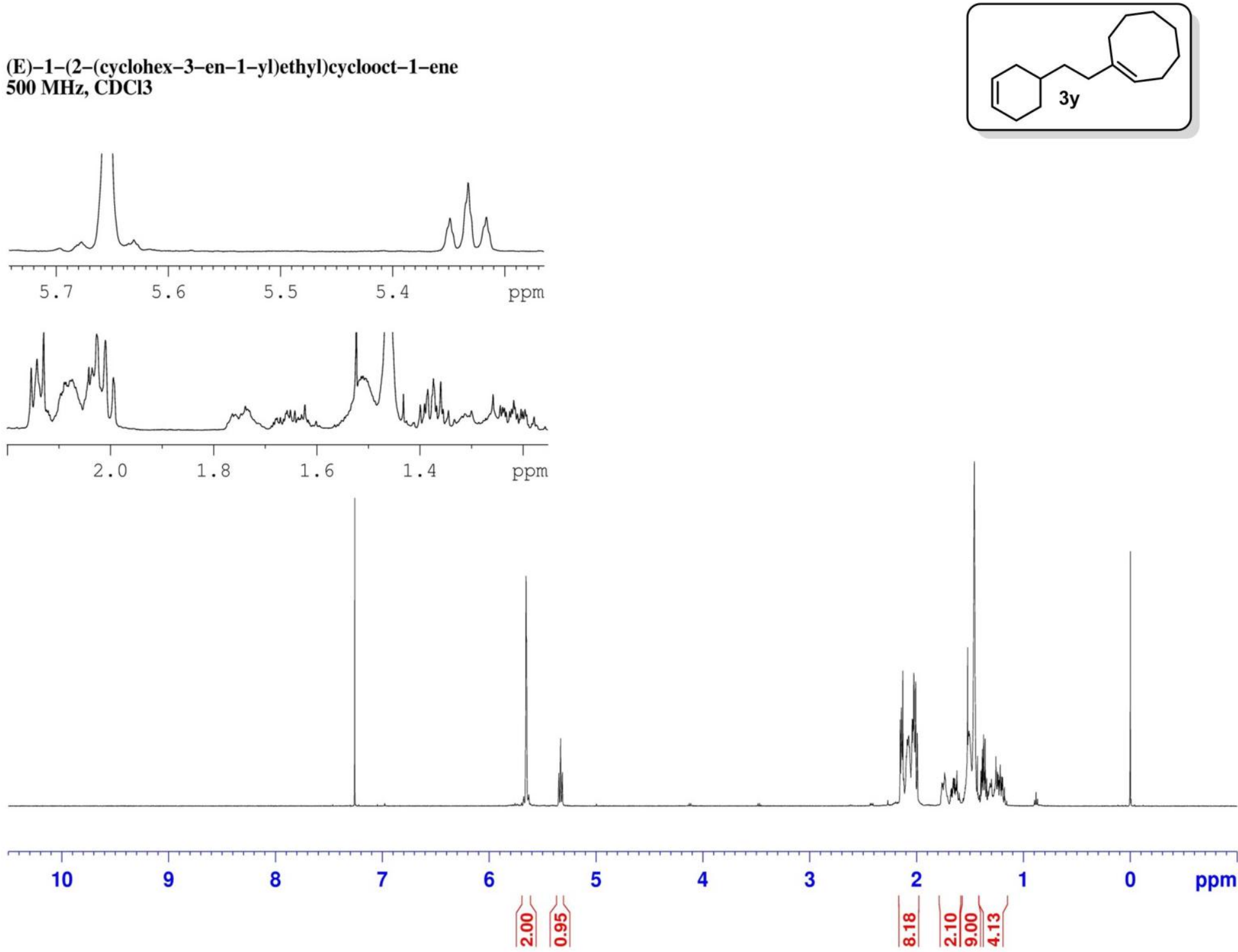
(E)-2-(cyclooct-1-en-1-yl)bicyclo[2.2.1]heptane $500 \mathrm{MHz}, \mathrm{CDCl} 3$
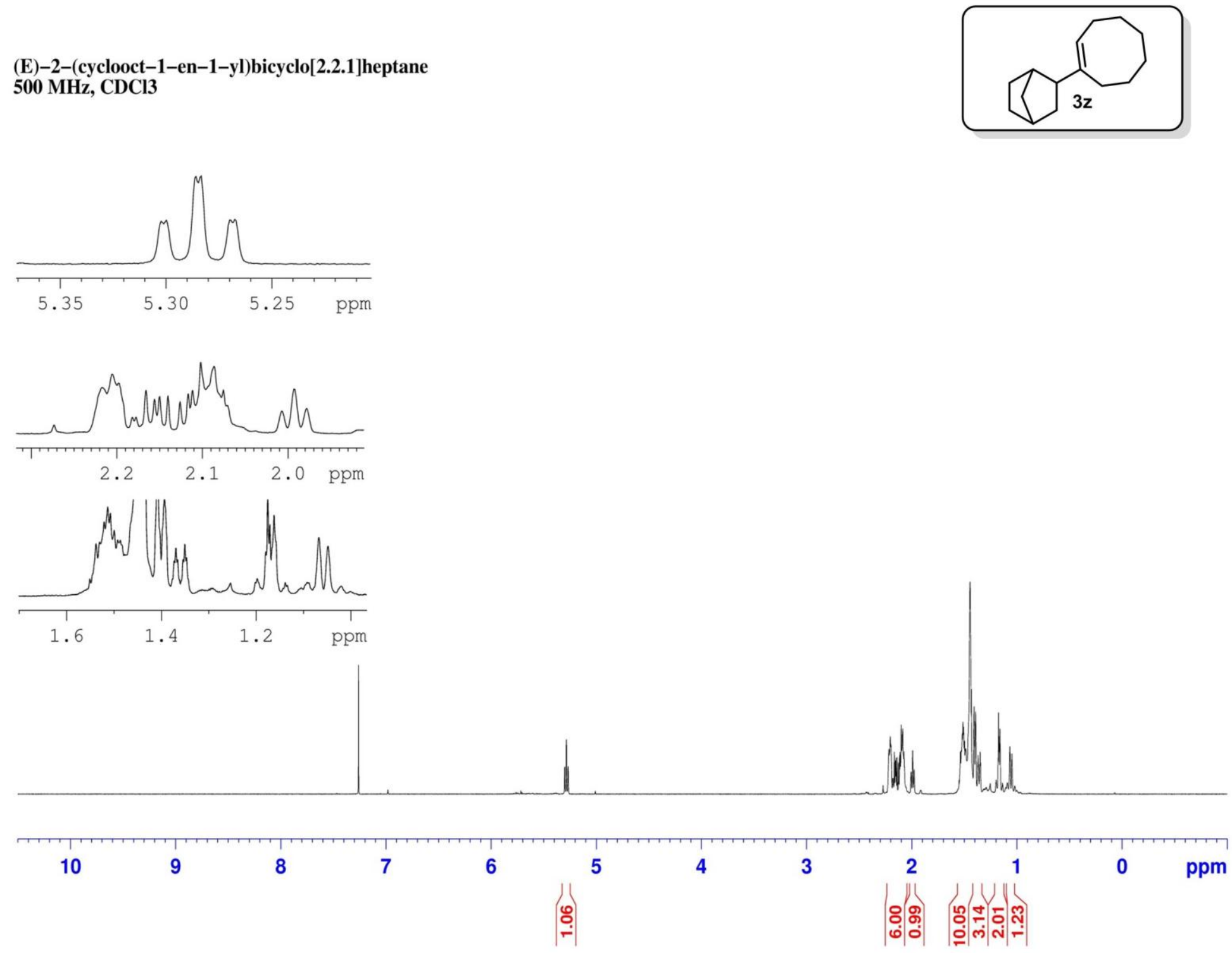
(E)-N-(3-(cyclooct-1-en-1-yl)propyl)acetamide
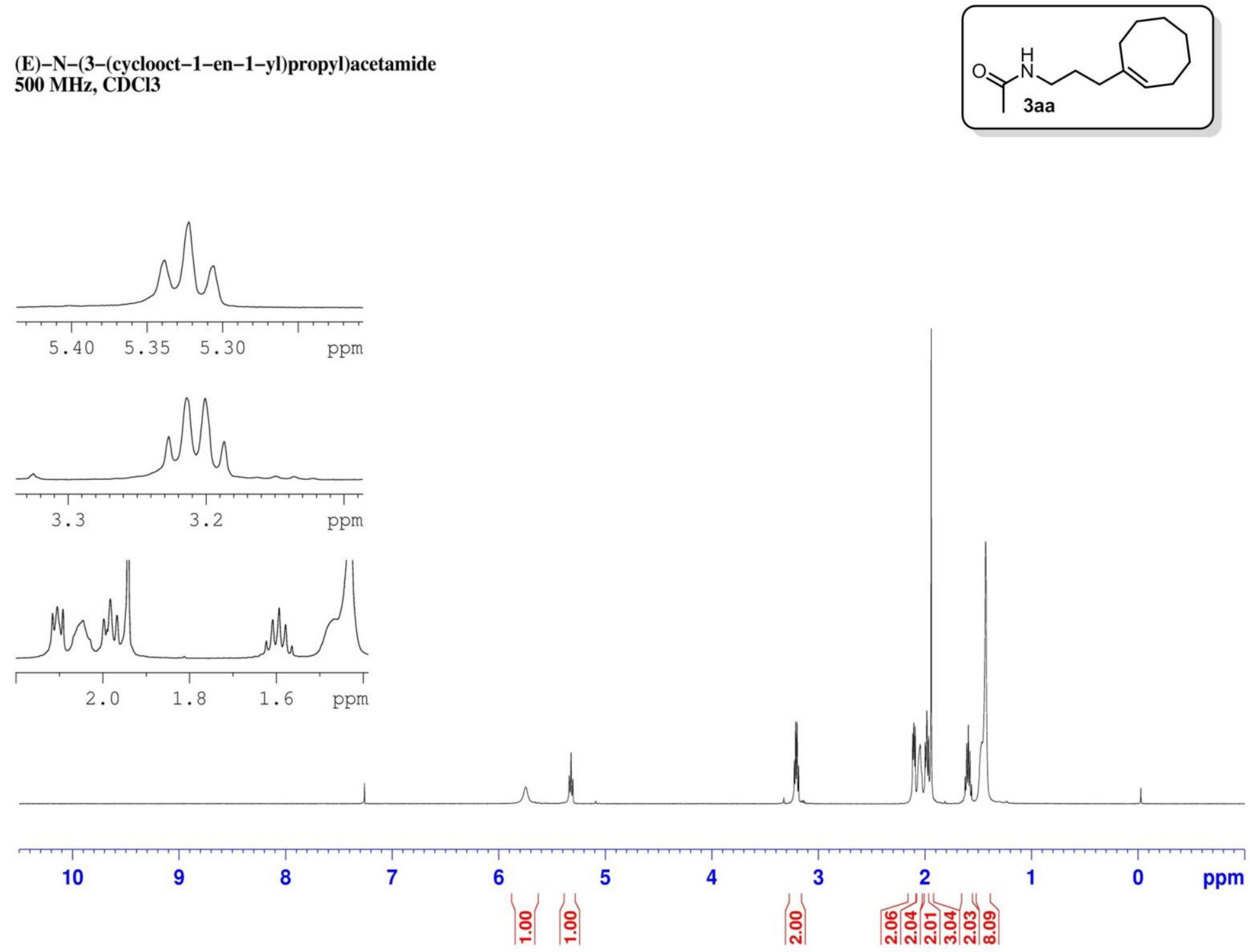
(E)-3-(cyclooct-1-en-1-yl)propan-1-amine

$500 \mathrm{MHz}, \mathrm{CDCl}^{3}$
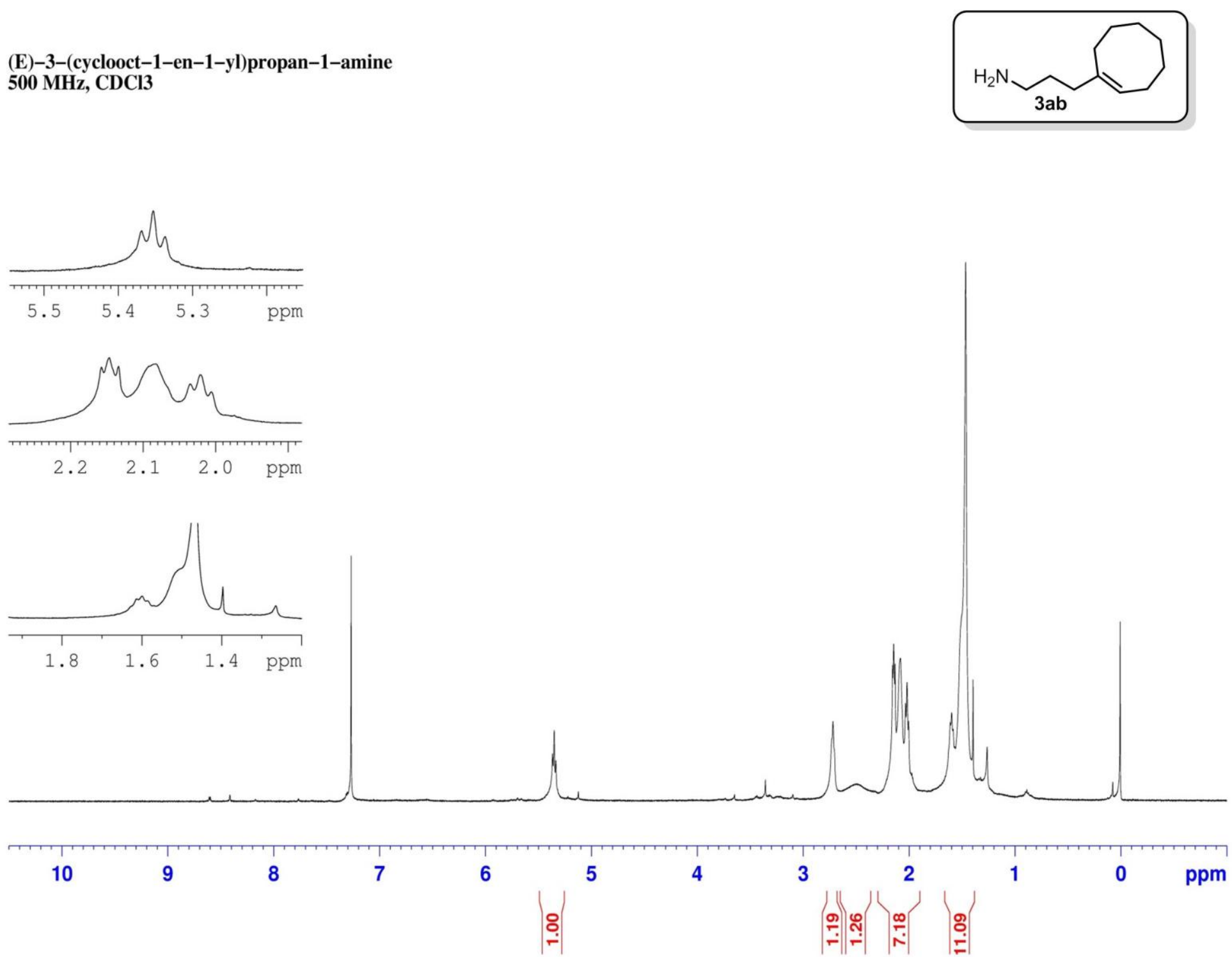
(Z)-ethyl 4-phenylbut-2-enoate

$500 \mathrm{MHz}, \mathrm{CDCl} 3$
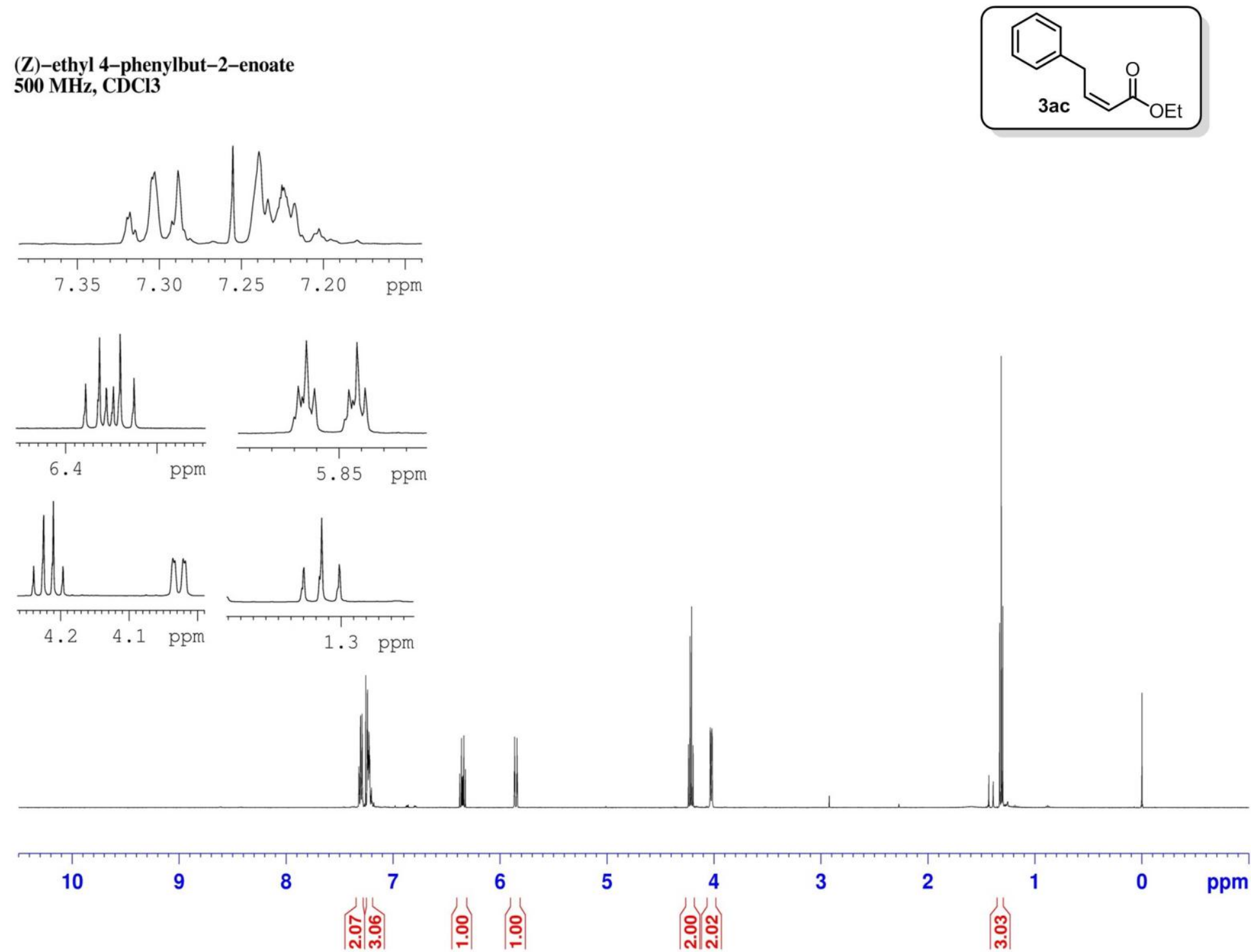
(Z)-Ethyl 5-(Cyclohex-3-en-1-yl)pent-2-enoate $500 \mathrm{MHz}, \mathrm{CDCl} 3$
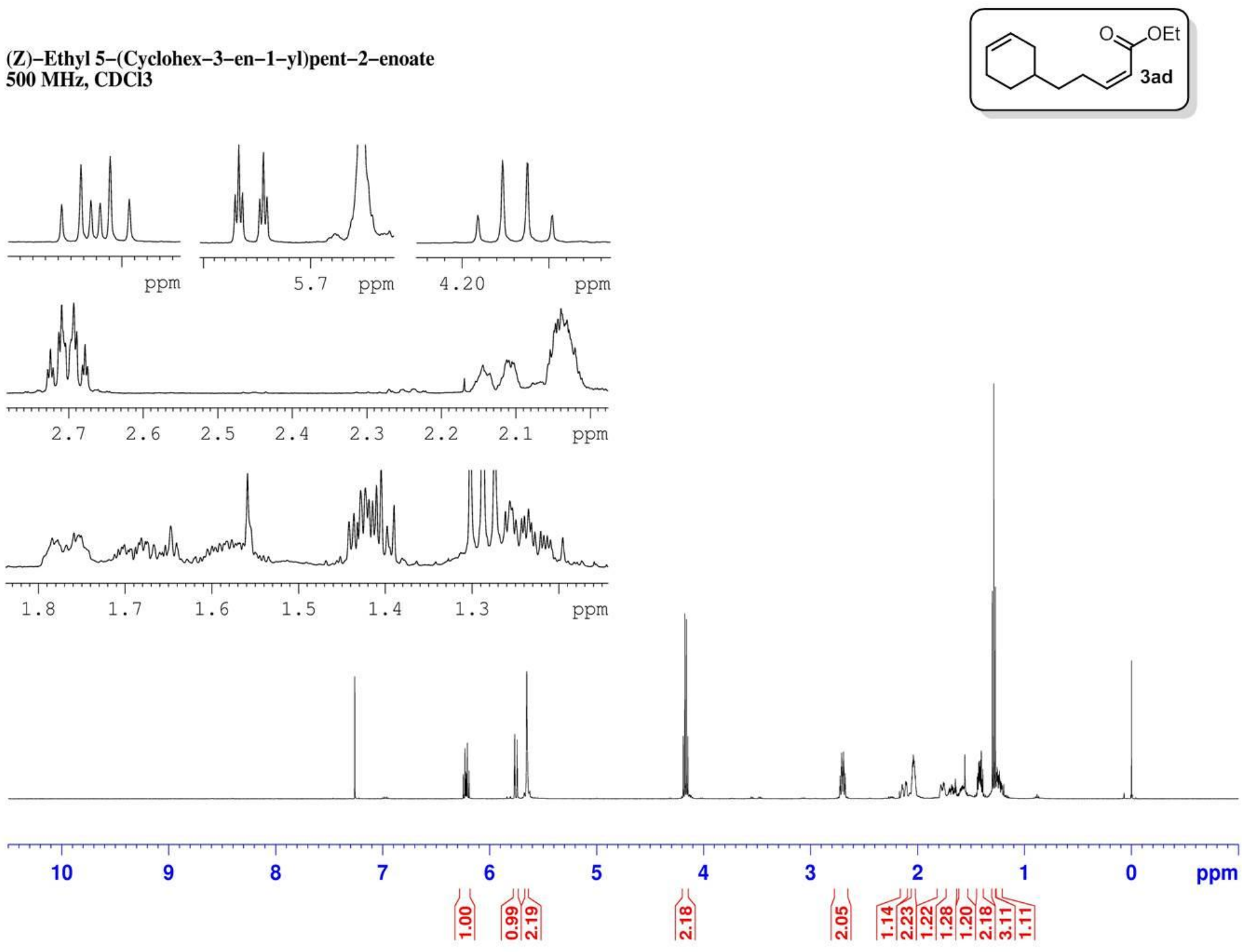
(Z)-ethyl 6-acetamidohex-2-enoate $500 \mathrm{MHz}, \mathrm{CDCl} 3$
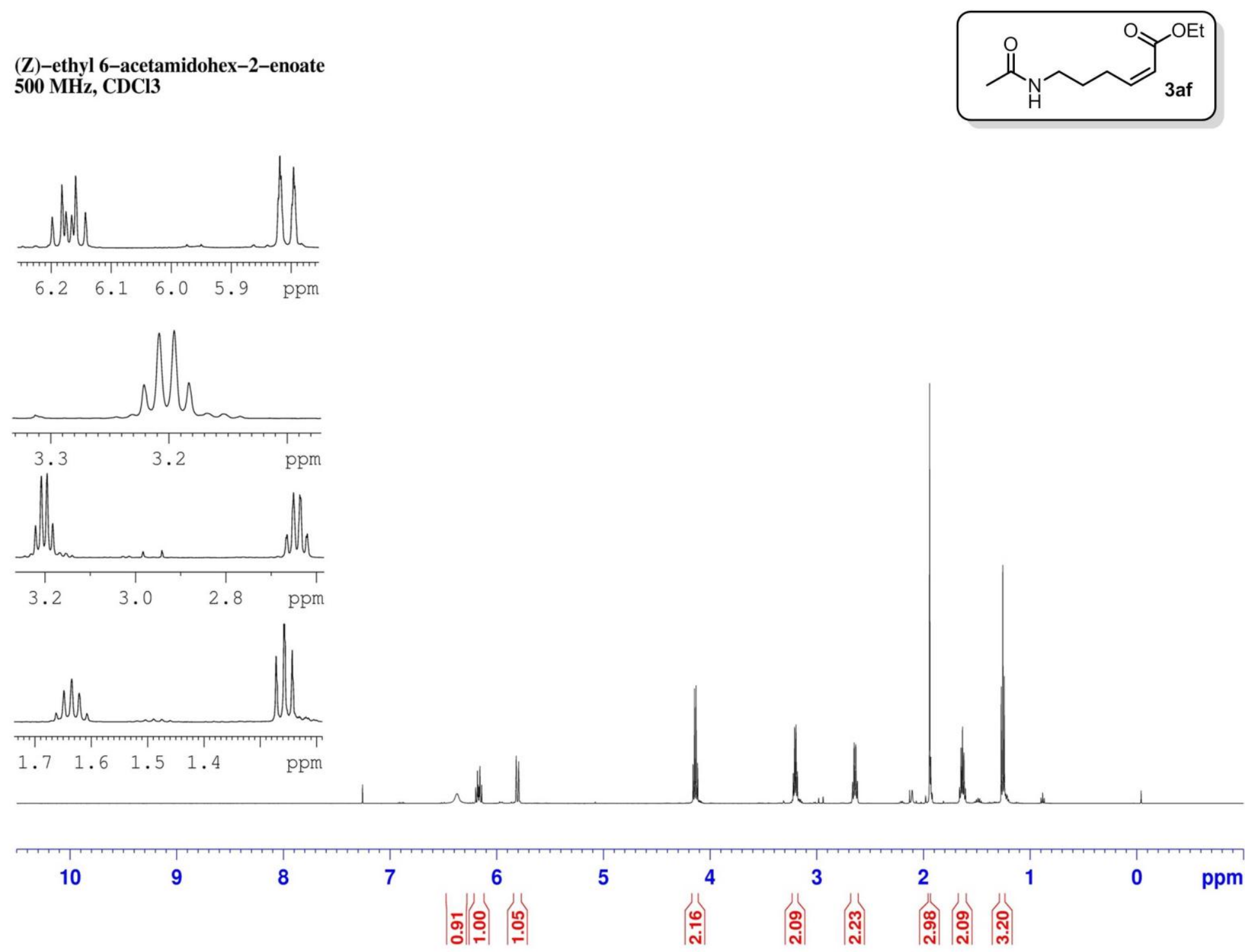
(2-cyclohexylideneethyl)benzene $500 \mathrm{MHz}, \mathrm{CDCl} 3$
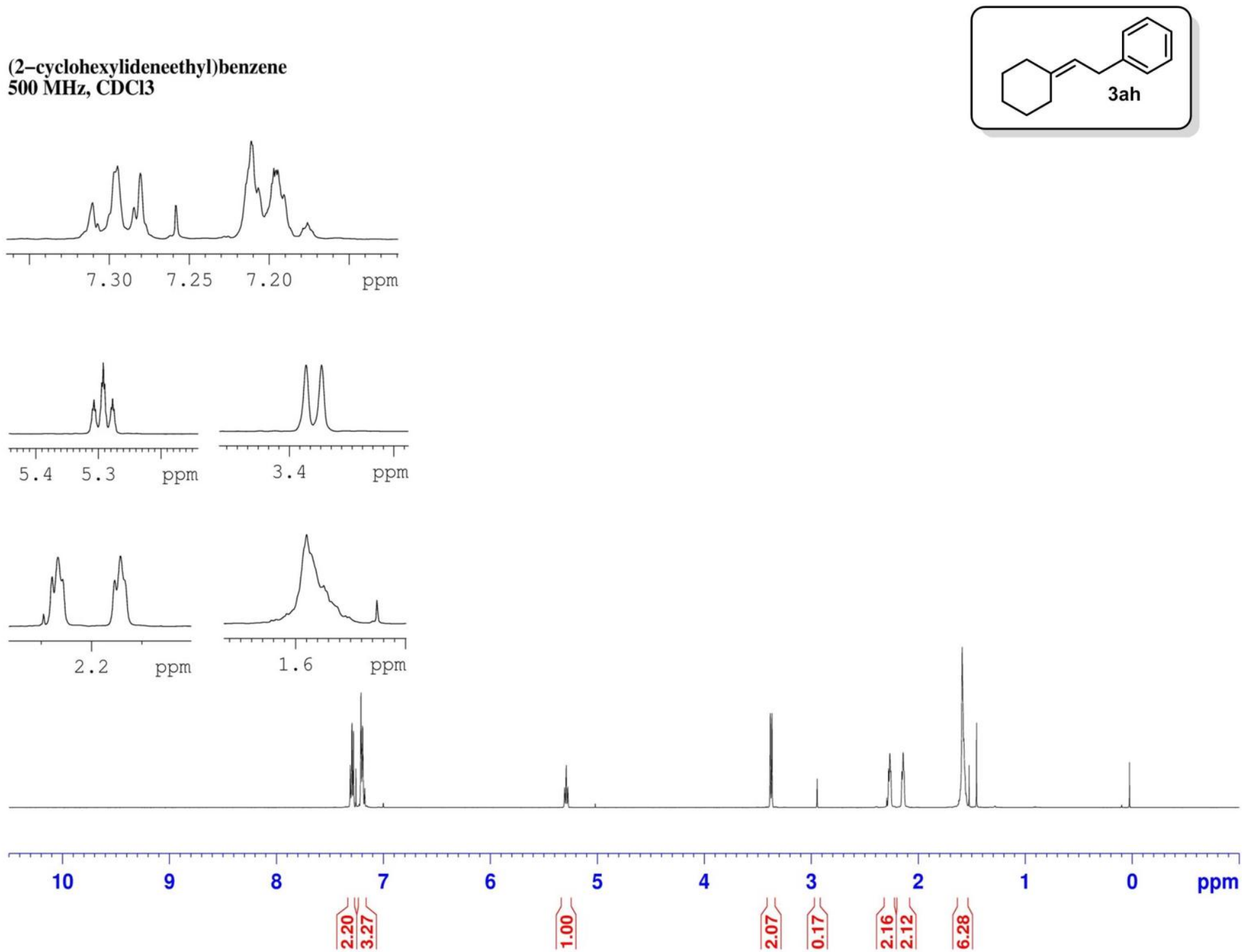
4-(3-cyclohexylidenepropyl)cyclohex-1-ene $500 \mathrm{MHz}, \mathrm{CDCl} 3$
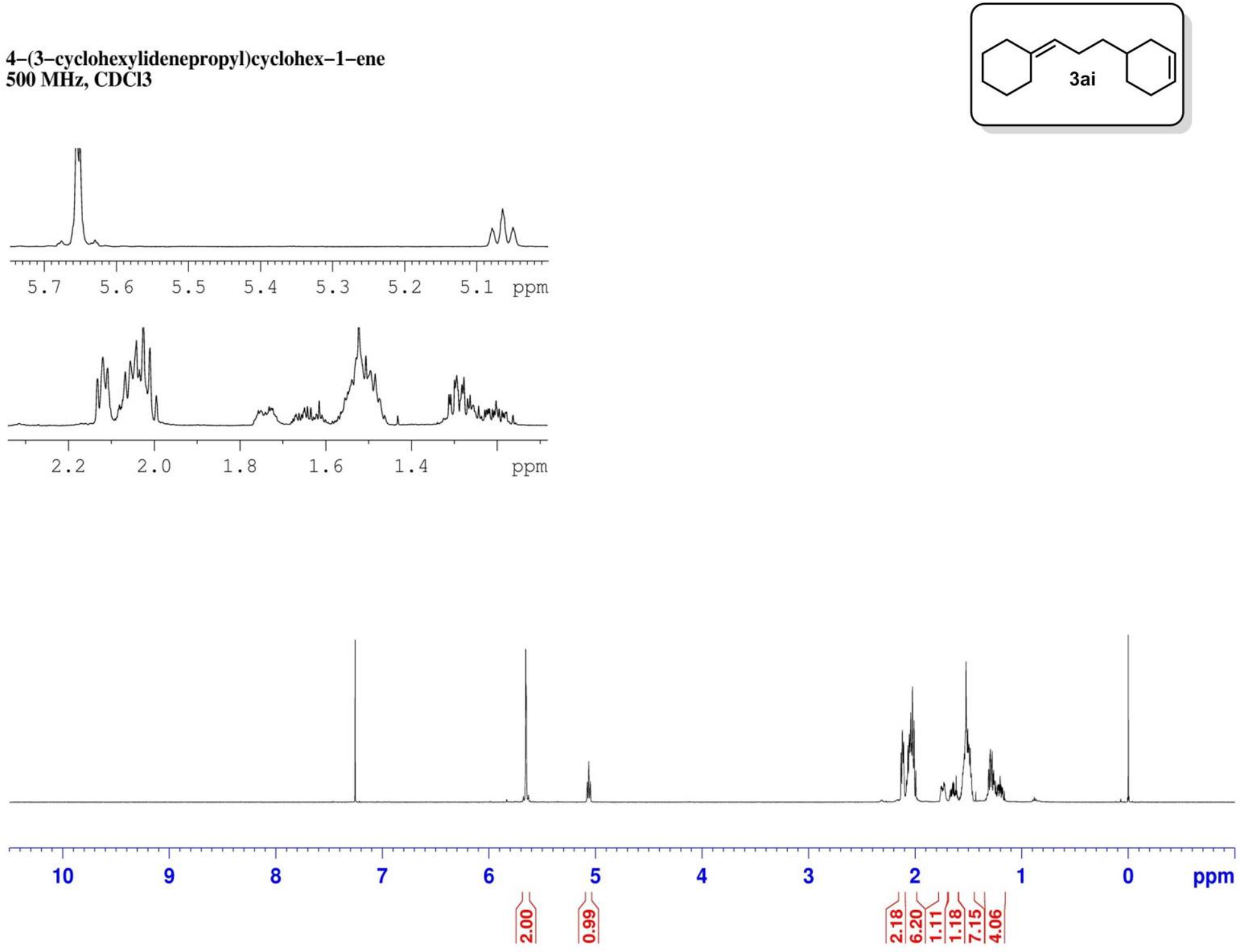
2-(cyclohexylidenemethyl)bicyclo[2.2.1]heptane $500 \mathrm{MHz}, \mathrm{CDCl} 3$
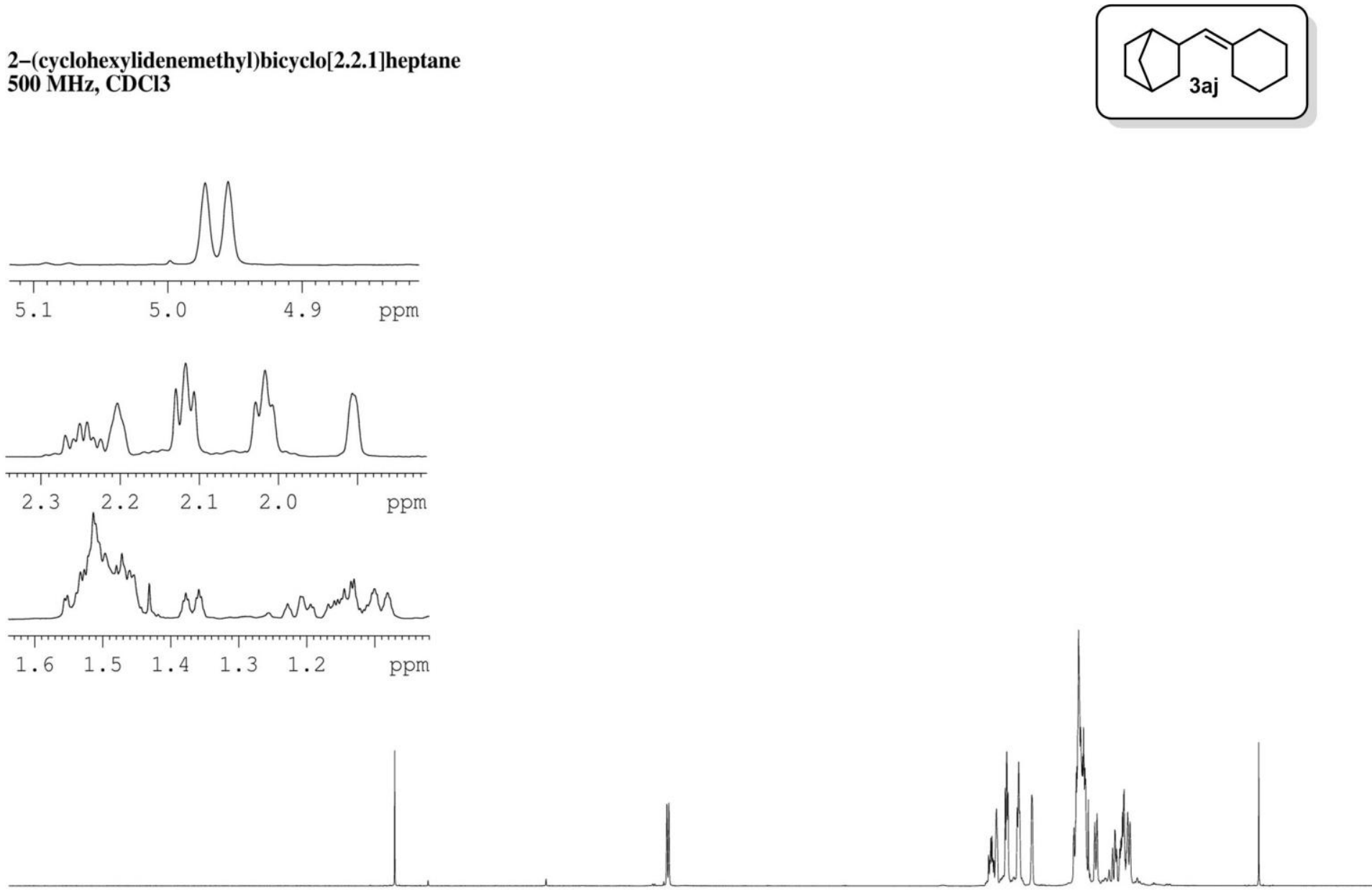

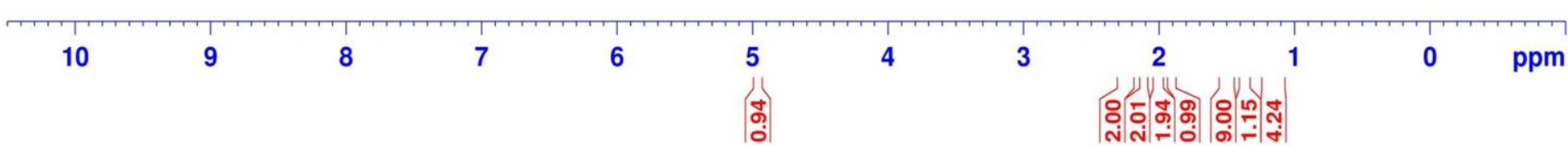


N-(4-cyclohexylidenebutyl)acetamide $500 \mathrm{MHz}, \mathrm{CDCl} 3$
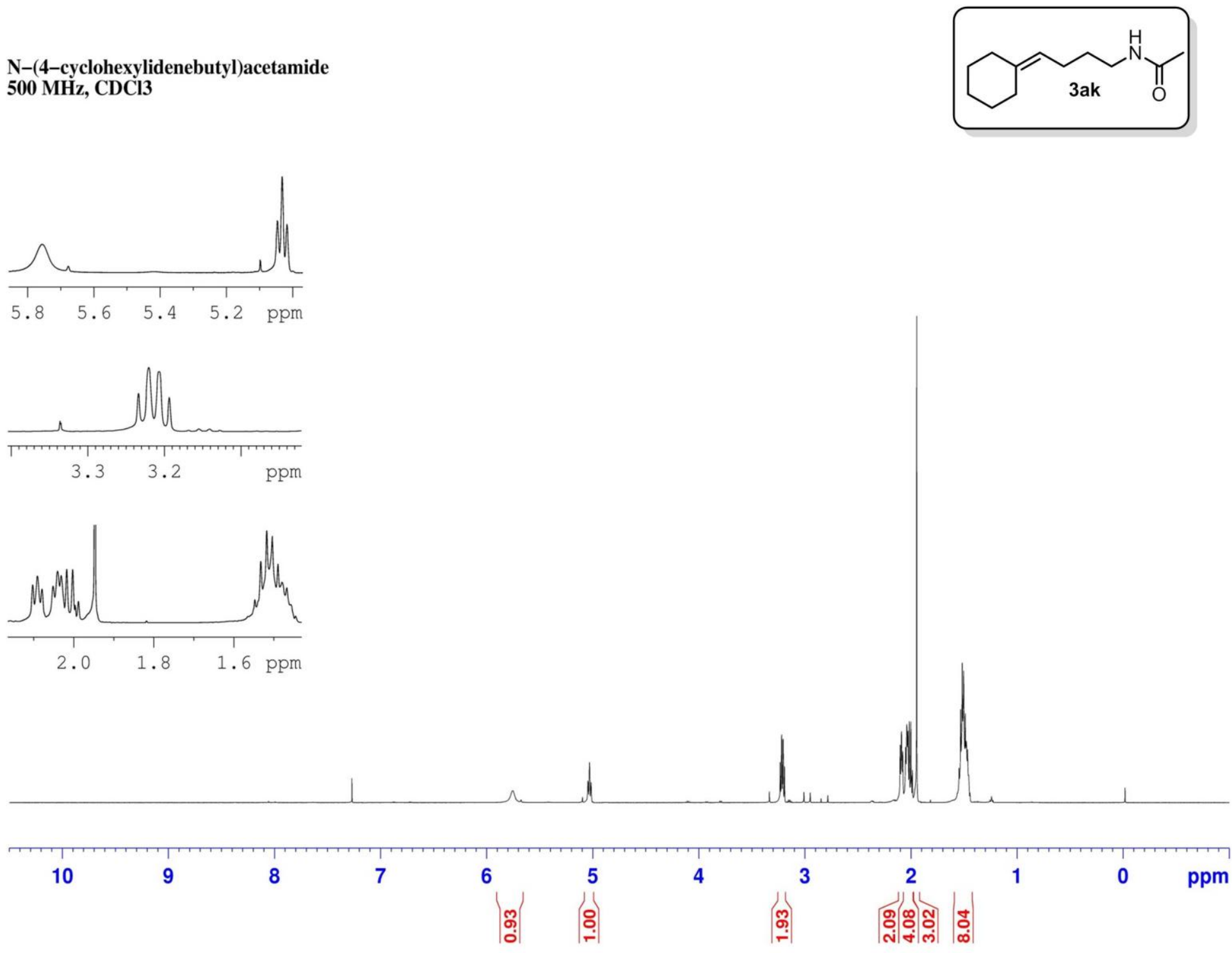
3-(cyclopent-1-en-1-yl)propyl acetate
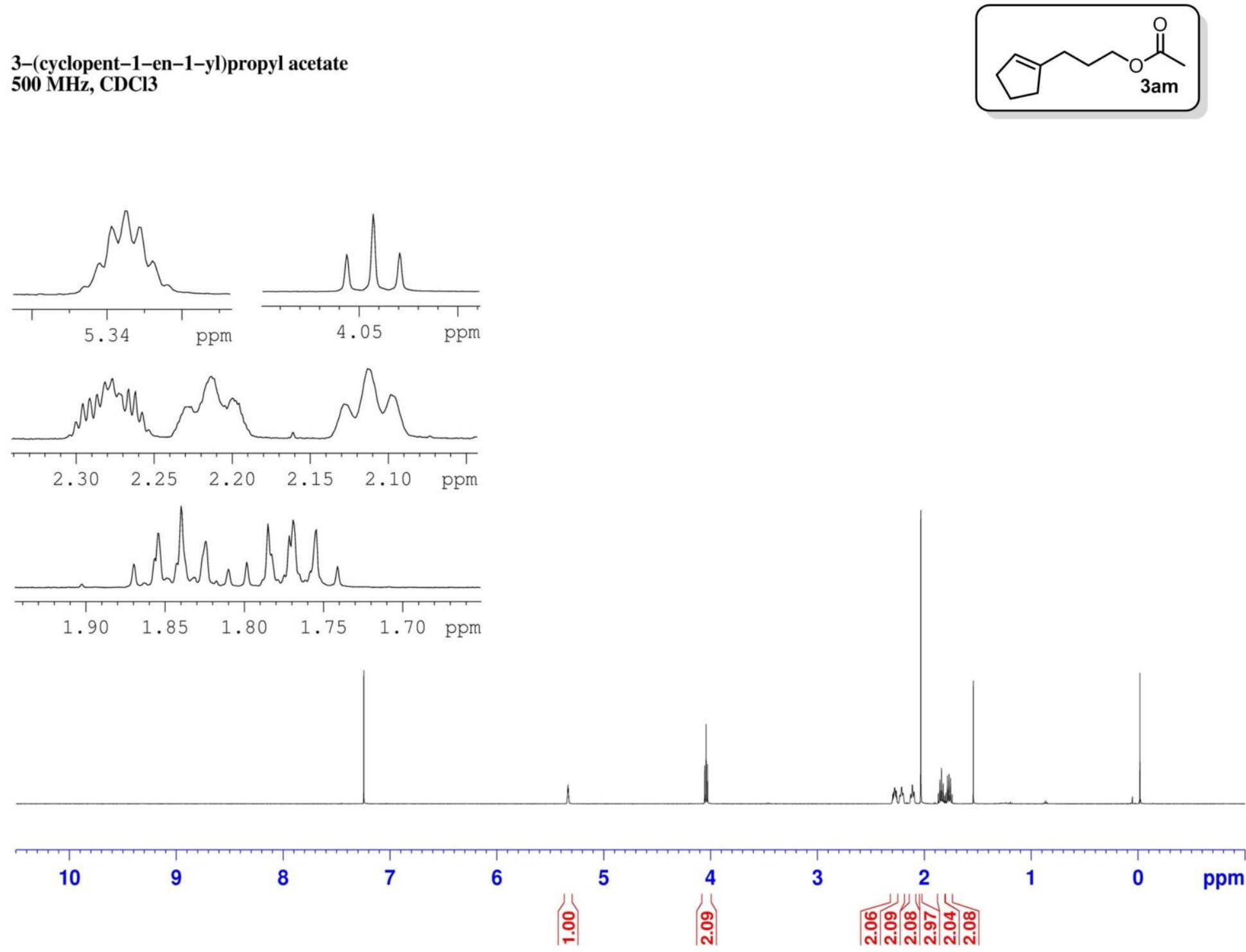

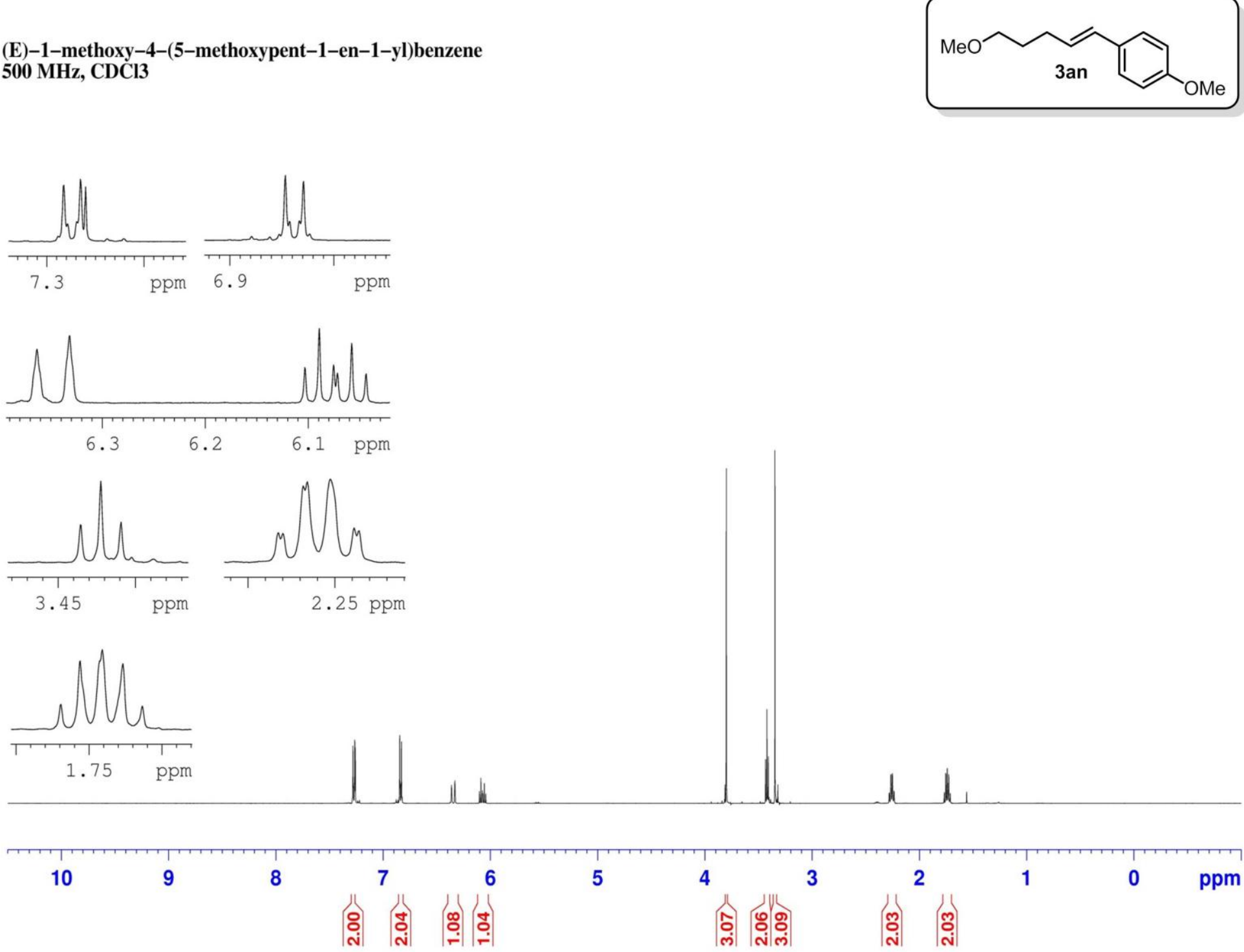


\section{${ }^{13}$ C NMR Spectra of Synthesized Compounds}

triethylammonium bis(catecholato)cyclopentylsilicate $125 \mathrm{MHz}, \mathrm{DMSO}-\mathrm{d} 6$
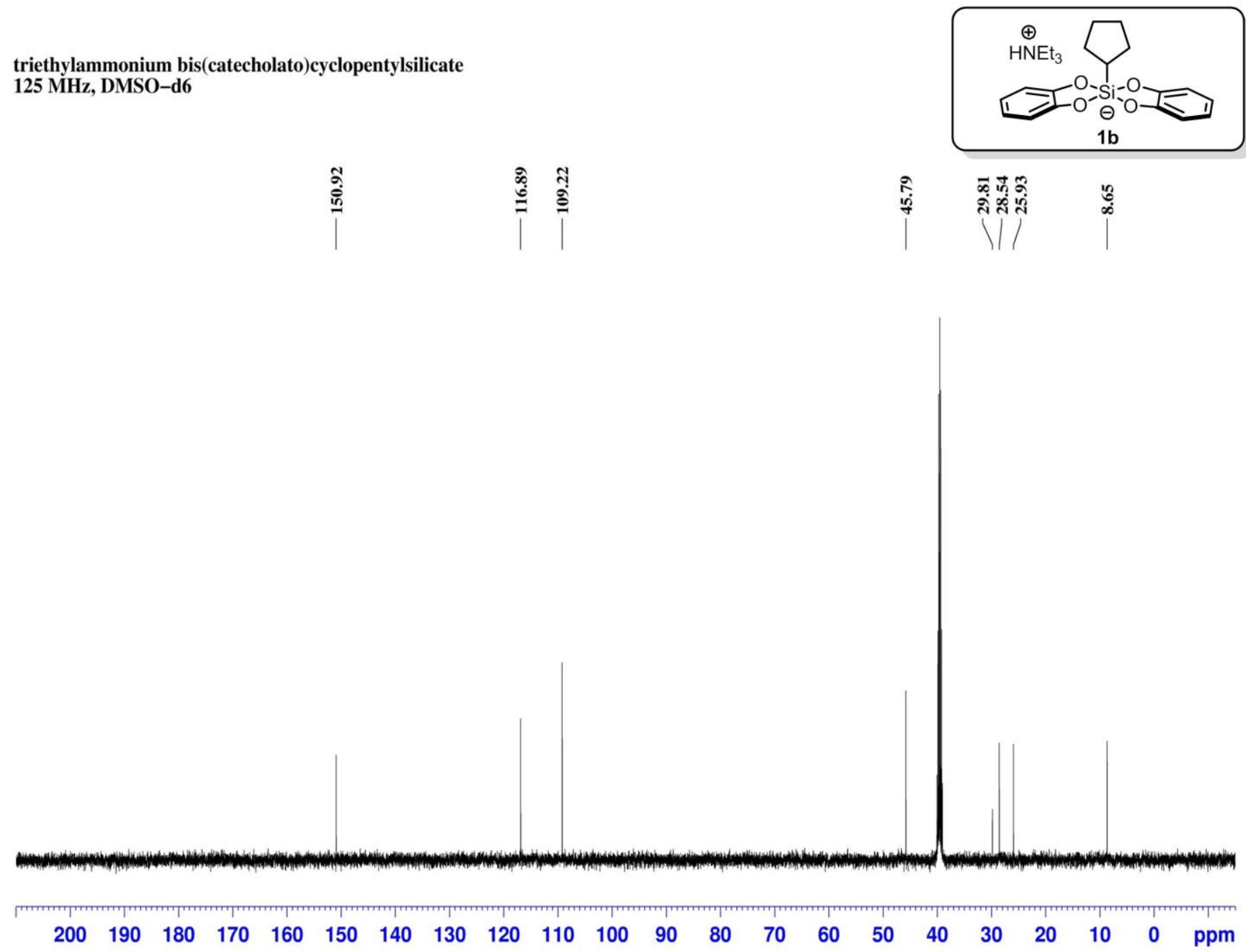
triethylammonium bis(catecholato)allylsilicate $125 \mathrm{MHz}$, DMSO-d6

$$
\text { | }
$$
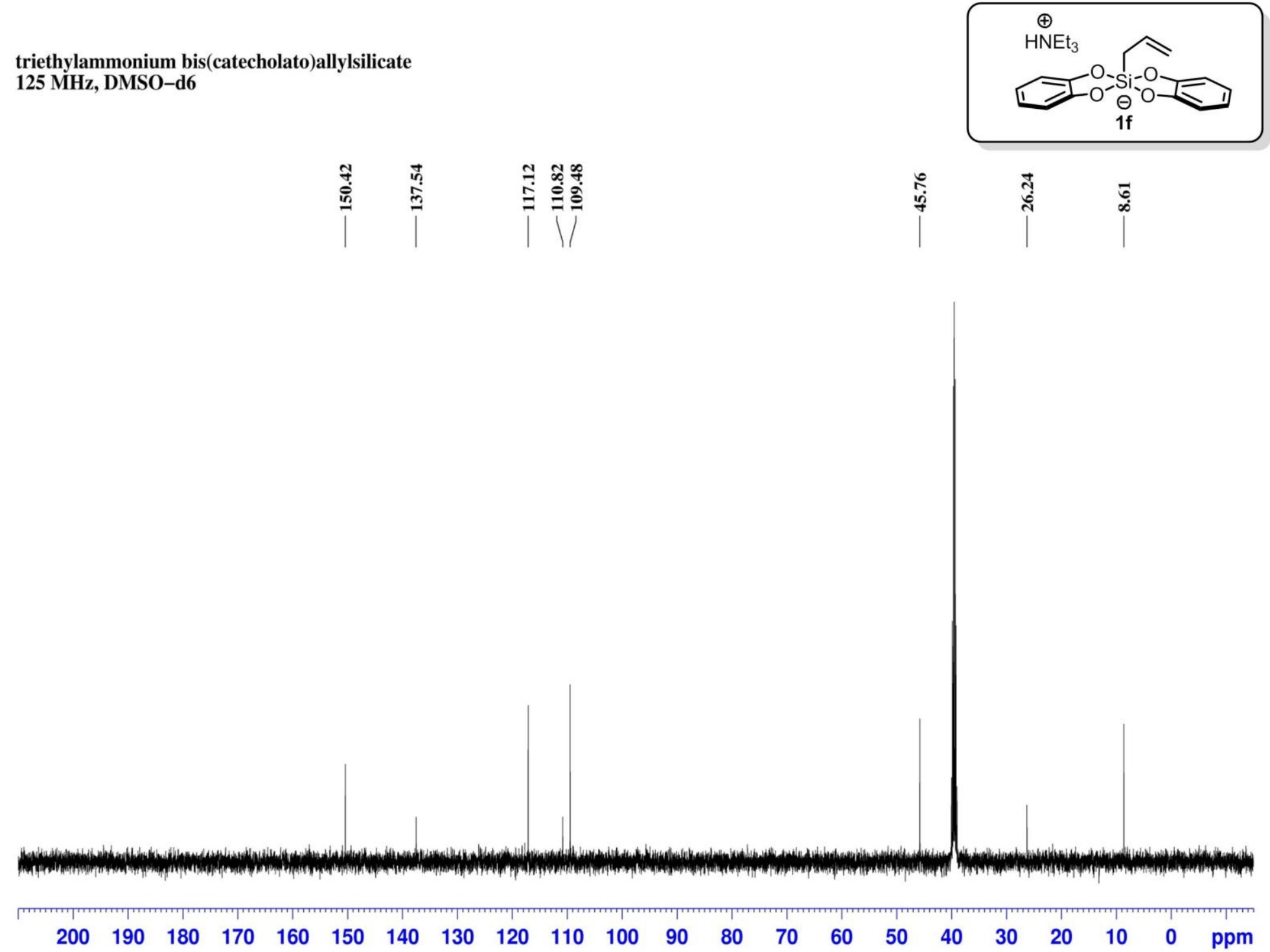
diisopropylammonium bis(catecholato)isobutylsilicate 125 MHz, DMSO-d6
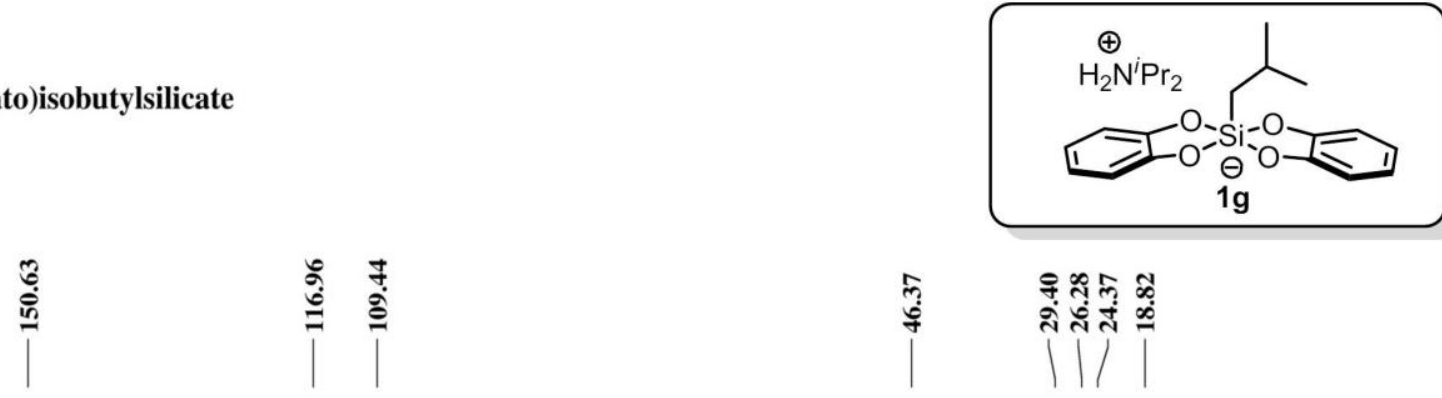

ำ

1 11

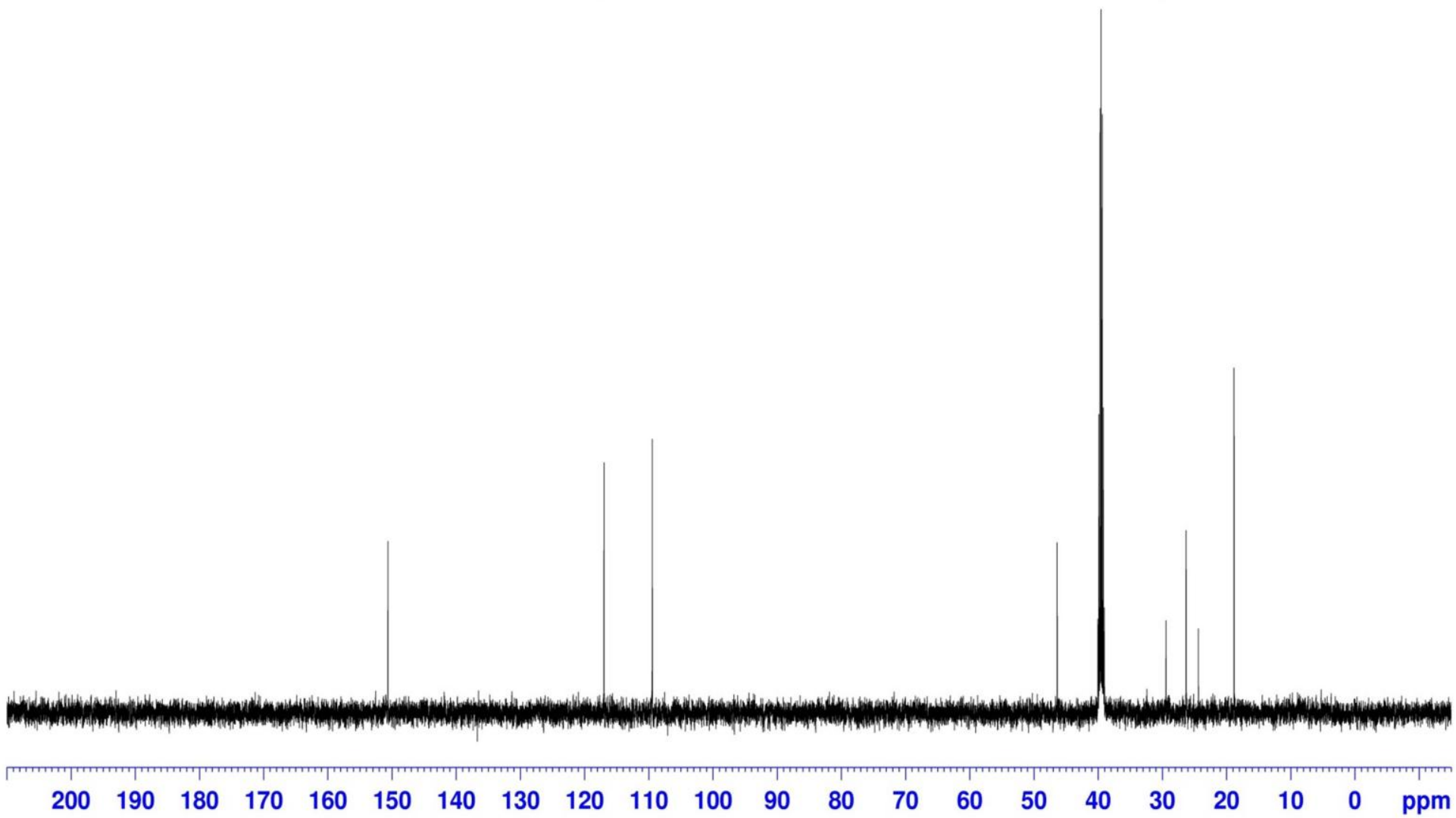


diisopropylammonium bis(catecholato)(3-methoxypropyl)silicate 125 MHz, DMSO-d6

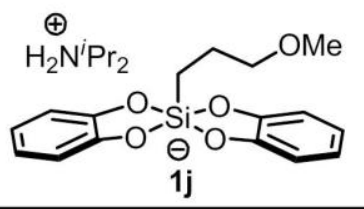

|

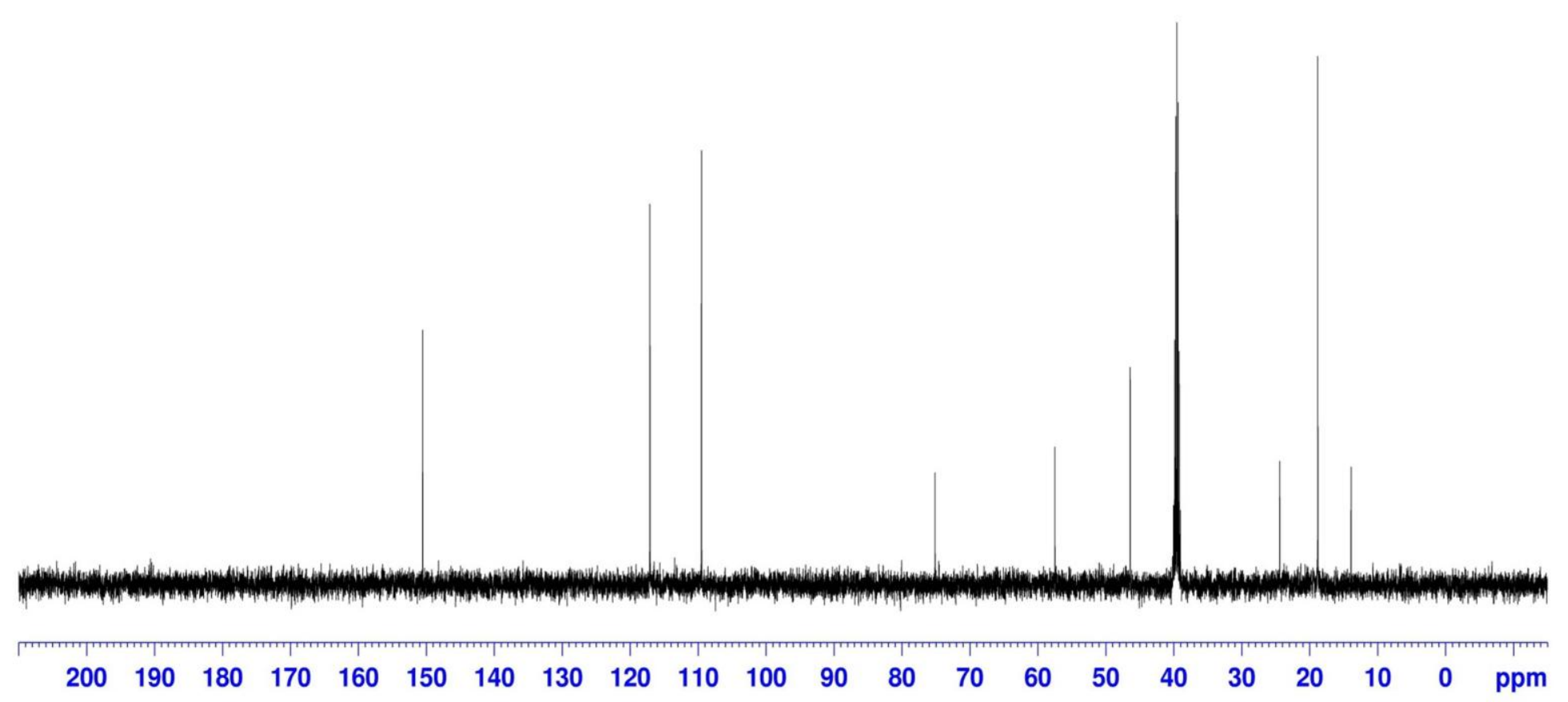


diisopropylammonium bis(catecholato)(3-acetamidopropyl)silicate 125 MHz, DMSO-d6

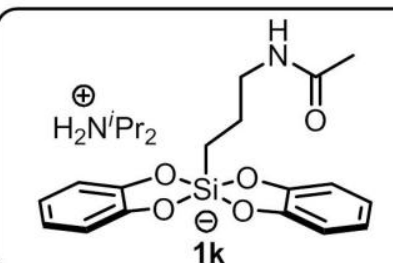

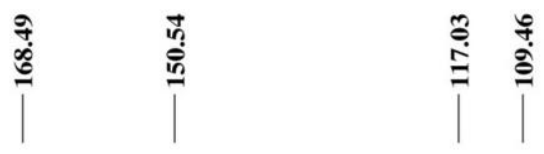

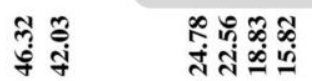

†

$\mid$

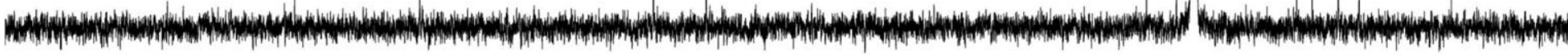

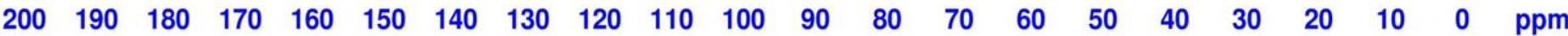


(E)-1-(2-bromovinyl)-4-methoxybenzene

$125 \mathrm{MHz}, \mathrm{CDCl} 3$
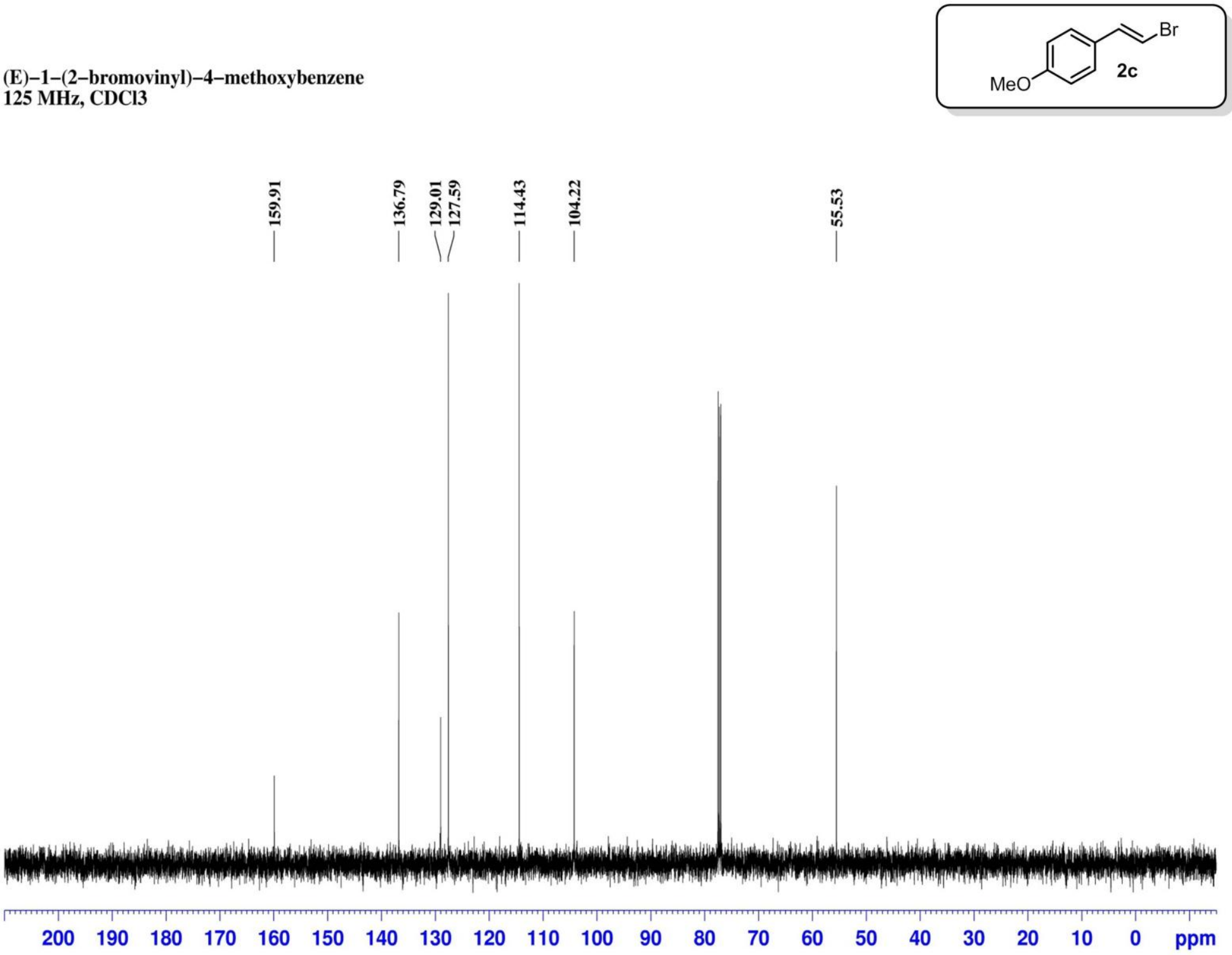

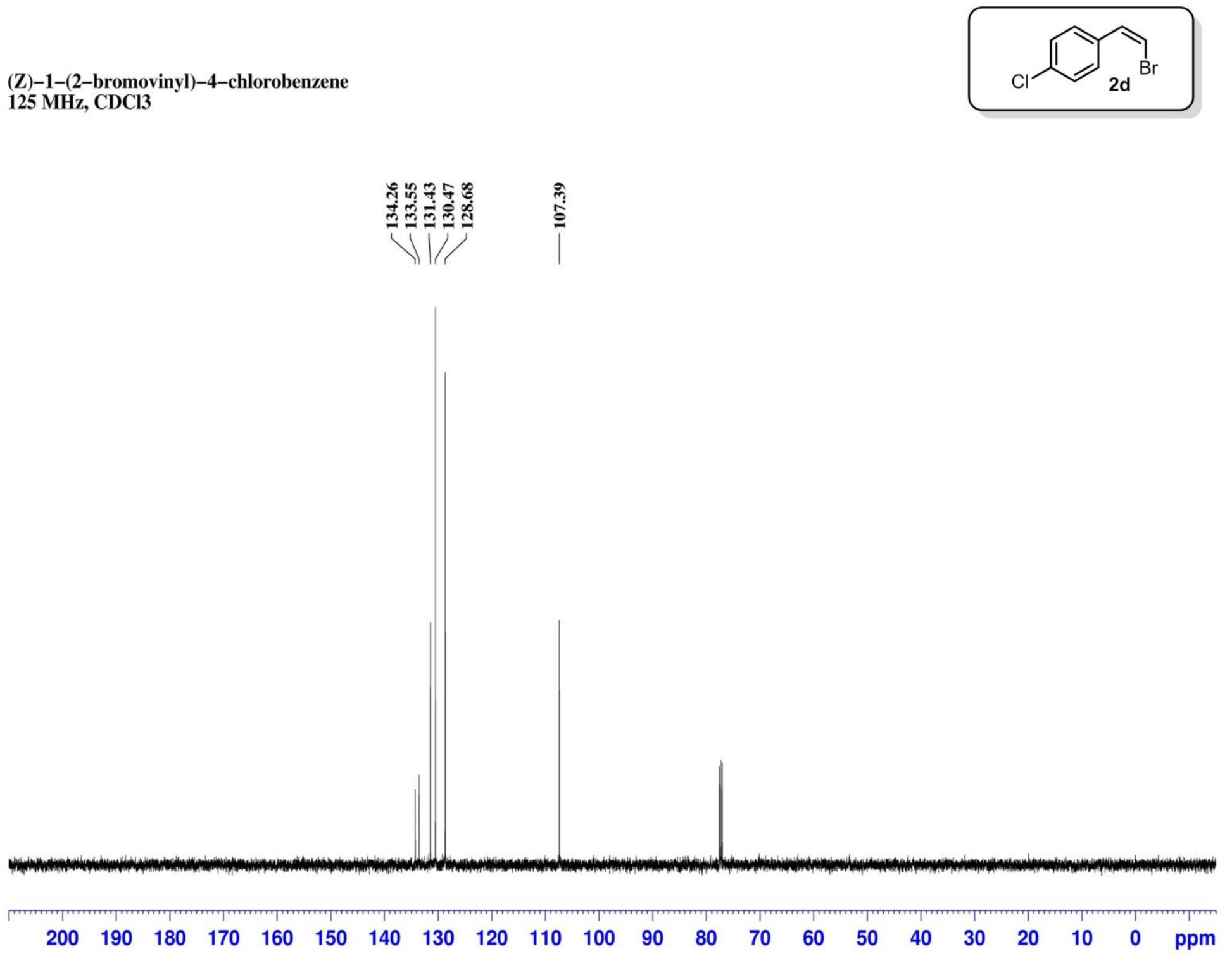
(E)-1-bromocyclooct-1-ene

$125 \mathrm{MHz}, \mathrm{CDCl} 3$

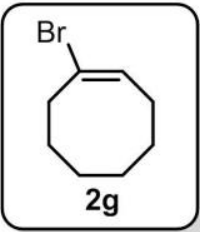

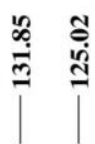

78

|VIV

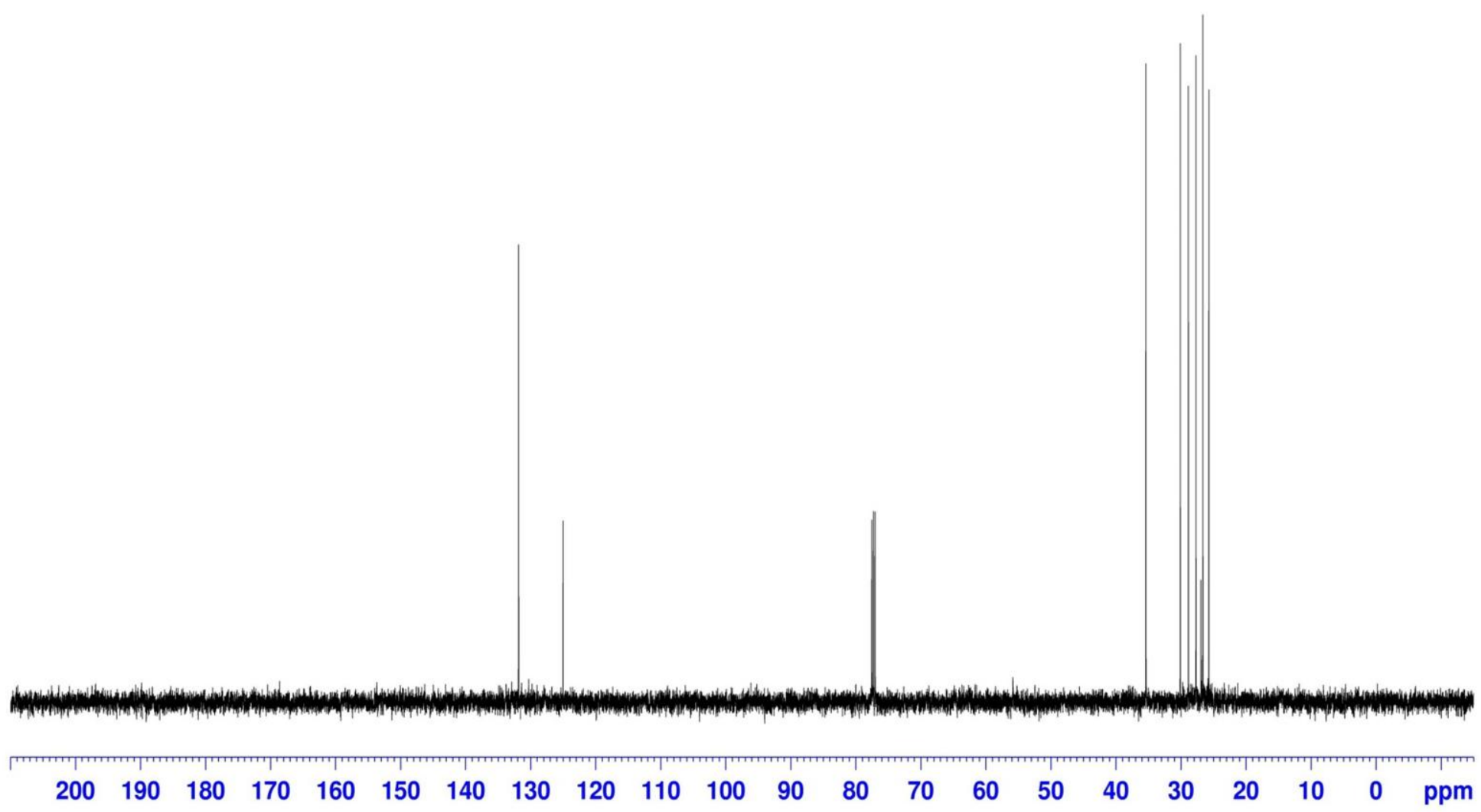


(E)-1-iodocyclooct-1-ene

$125 \mathrm{MHz}, \mathrm{CDCl} 3$
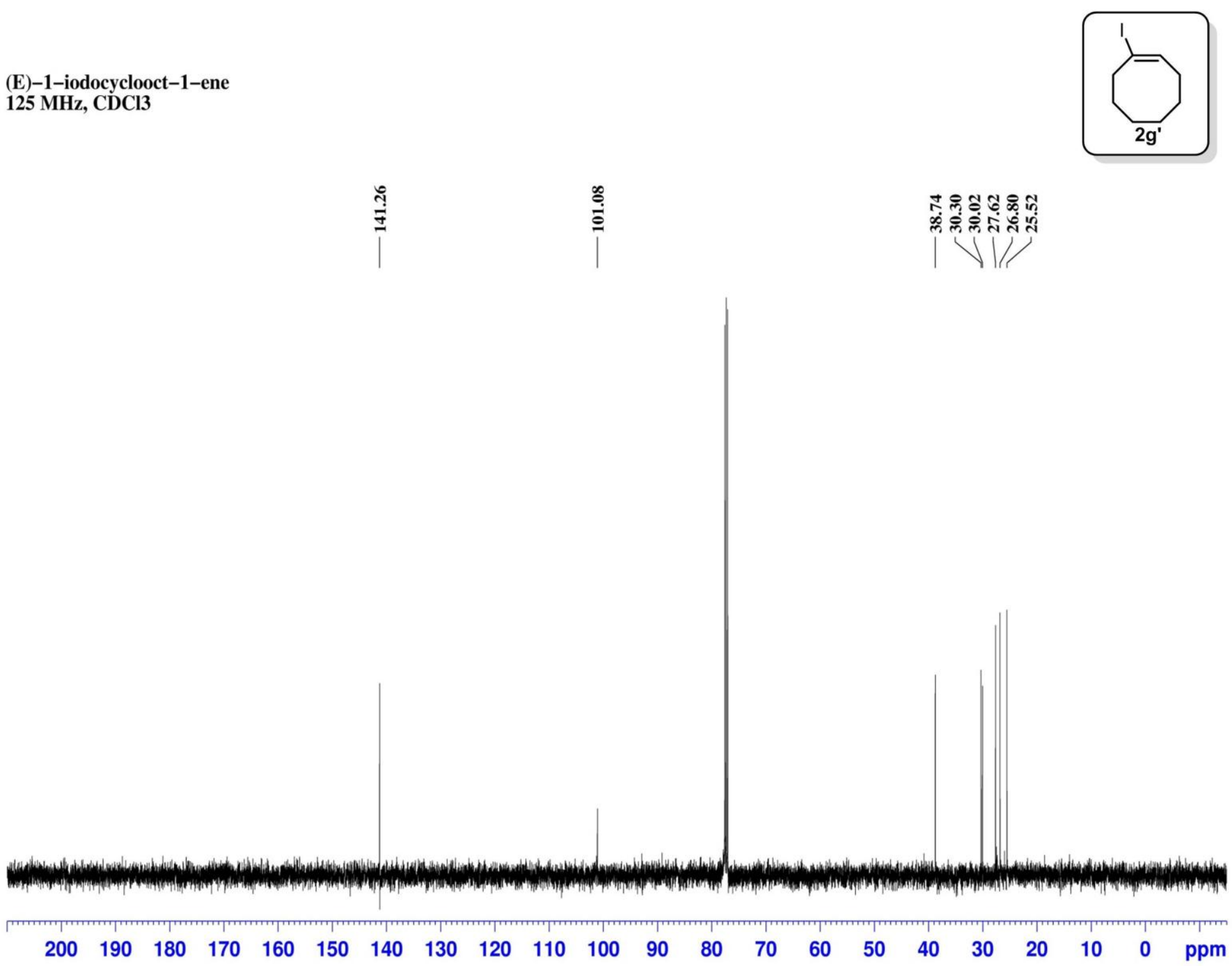
(Z)-3-bromoprop-2-en-1-ol $125 \mathrm{MHz}, \mathrm{CDCl} 3$

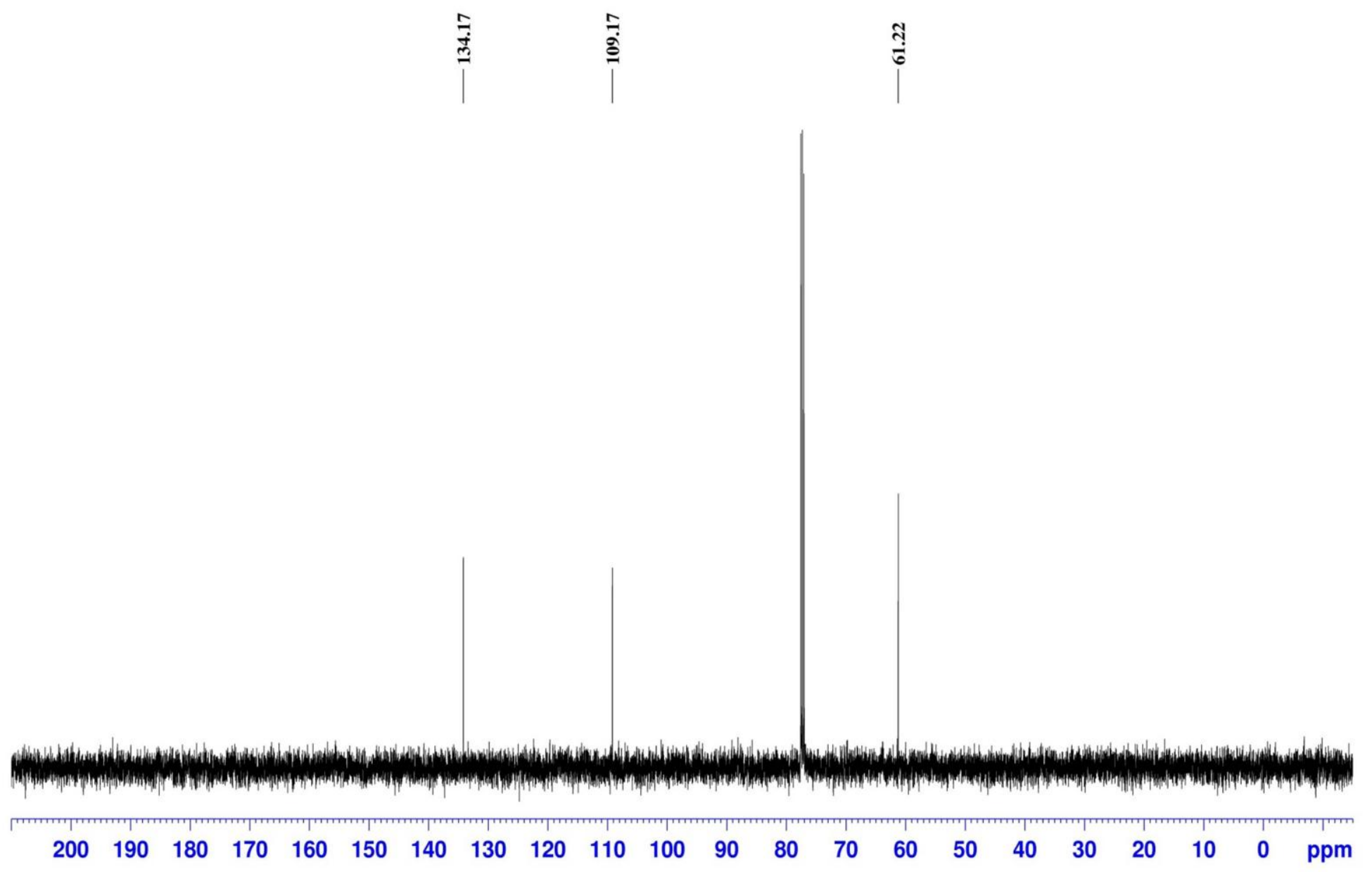


(Z)-((3-bromoallyl)oxy)(tert-butyl)dimethylsilane $125 \mathrm{MHz}, \mathrm{CDCl} 3$

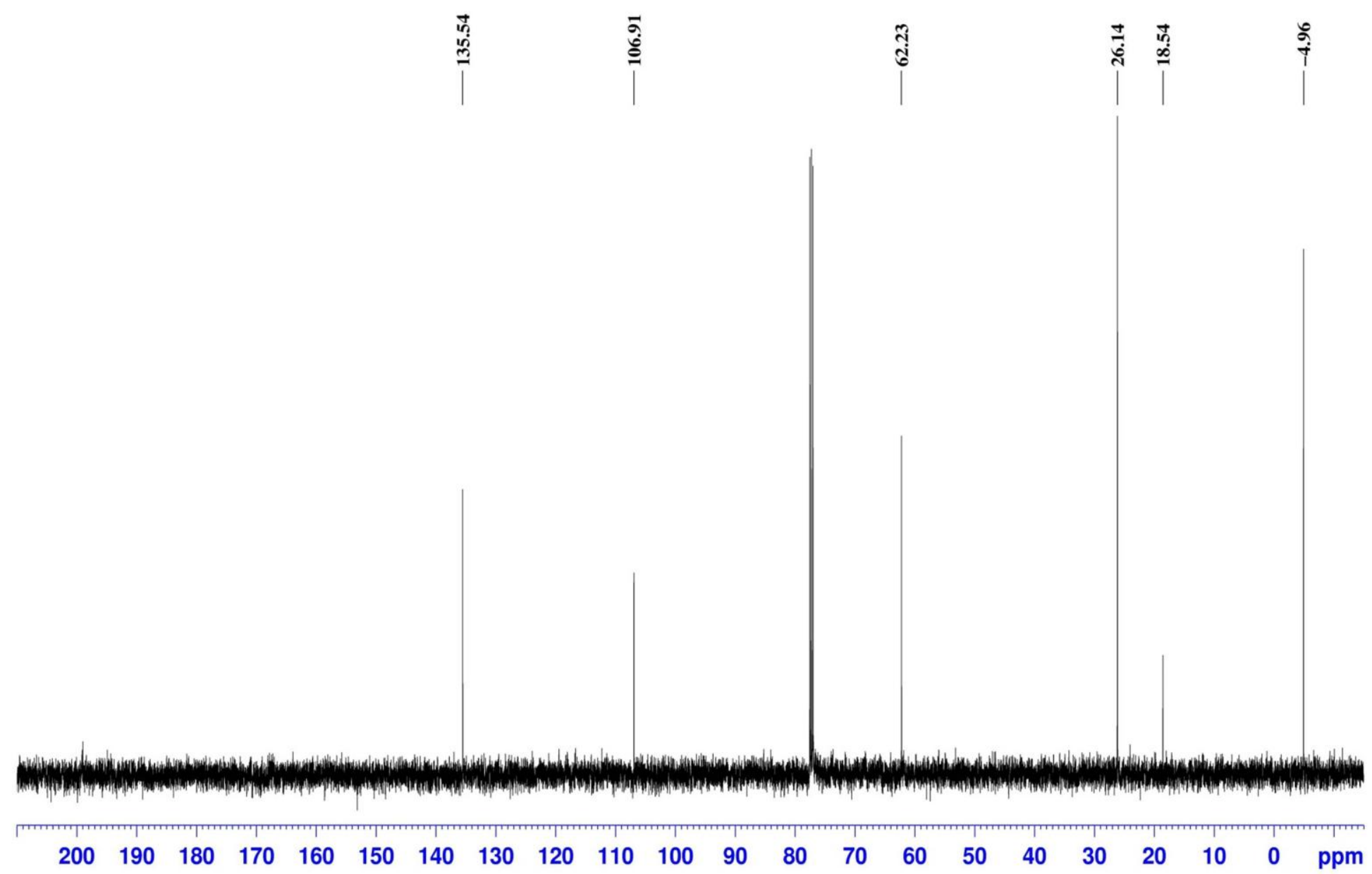



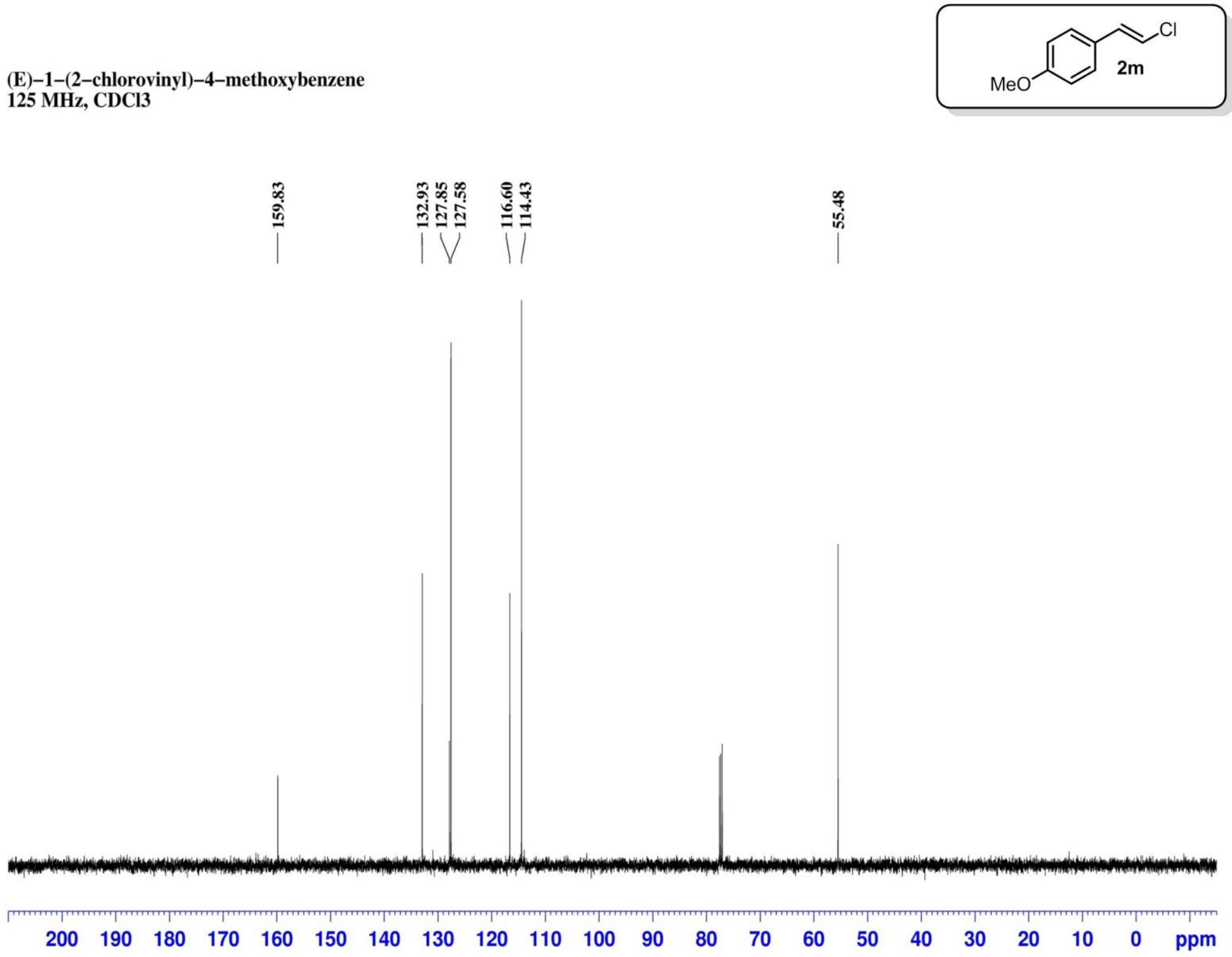
(Z)-ethyl 3-chloroacrylate

$125 \mathrm{MHz}, \mathrm{CDCl} 3$
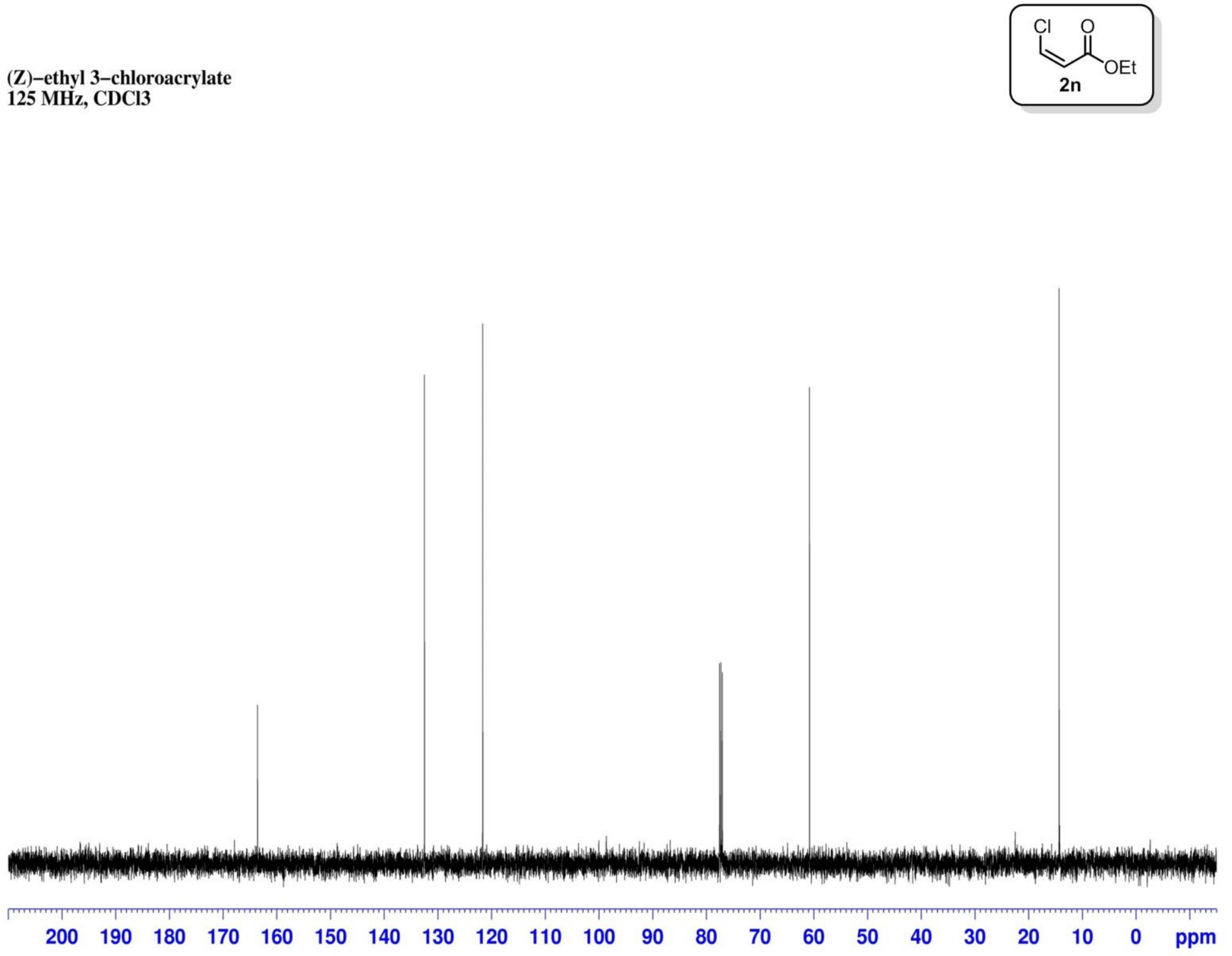
(E)-undec-4-en-1-yl acetate

$125 \mathrm{MHz}, \mathrm{CDCl} 3$
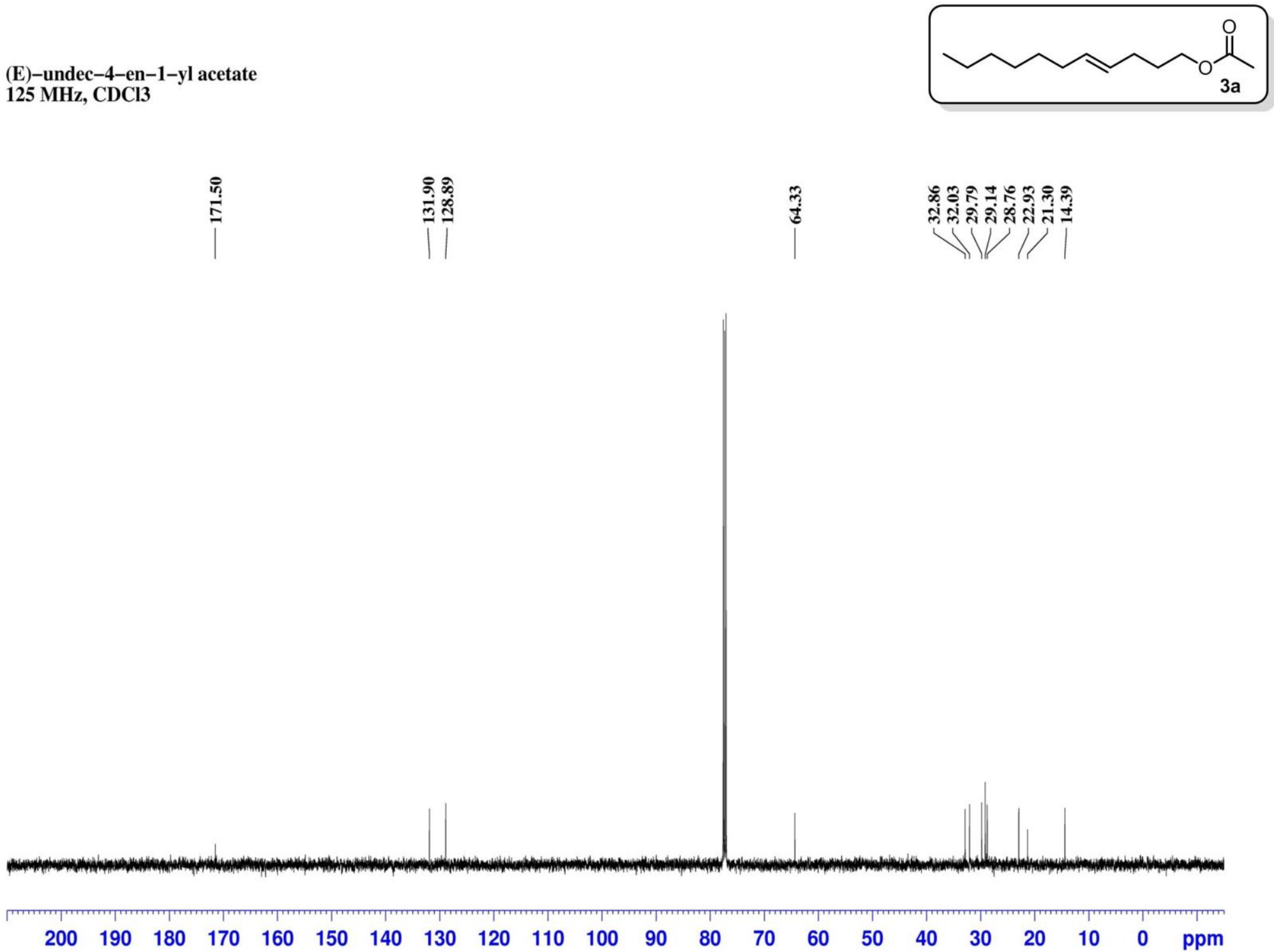
5-phenylpent-4-en-1-yl acetate

$125 \mathrm{MHz}, \mathrm{CDCl} 3$
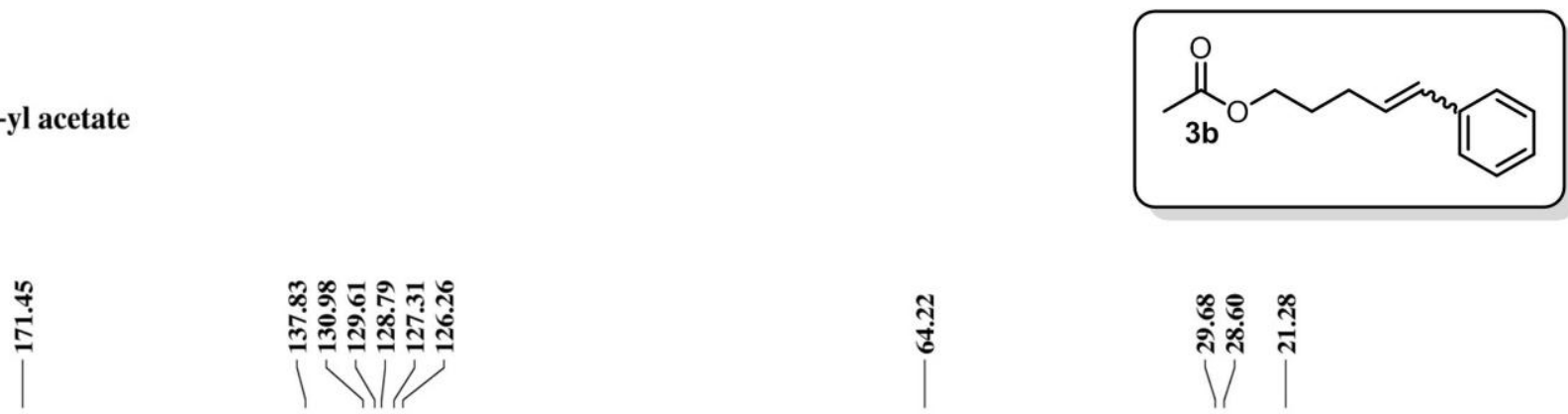

สิ

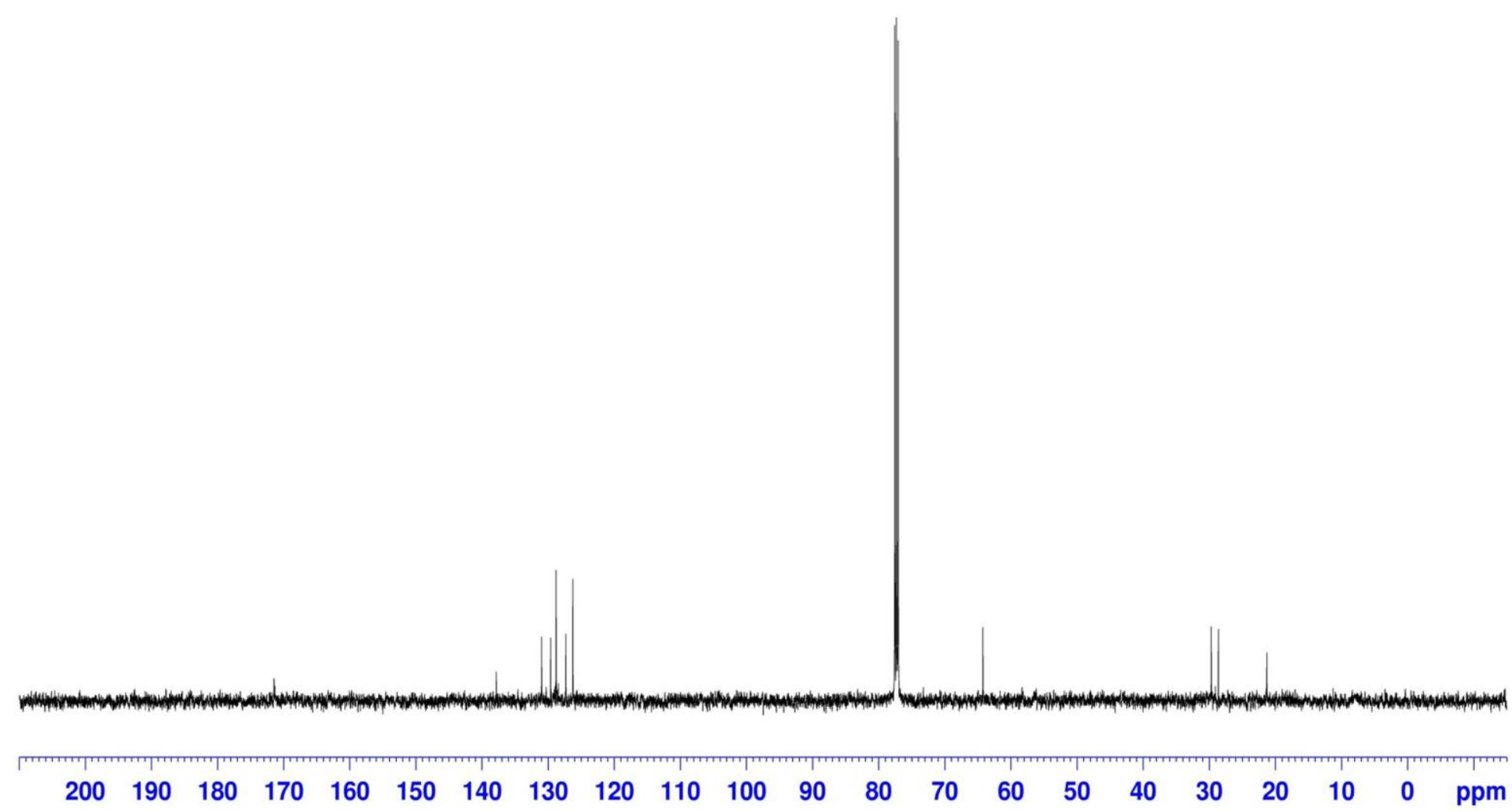


(E)-5-(4-methoxyphenyl)pent-4-en-1-yl acetate $125 \mathrm{MHz}, \mathrm{CDCl} 3$
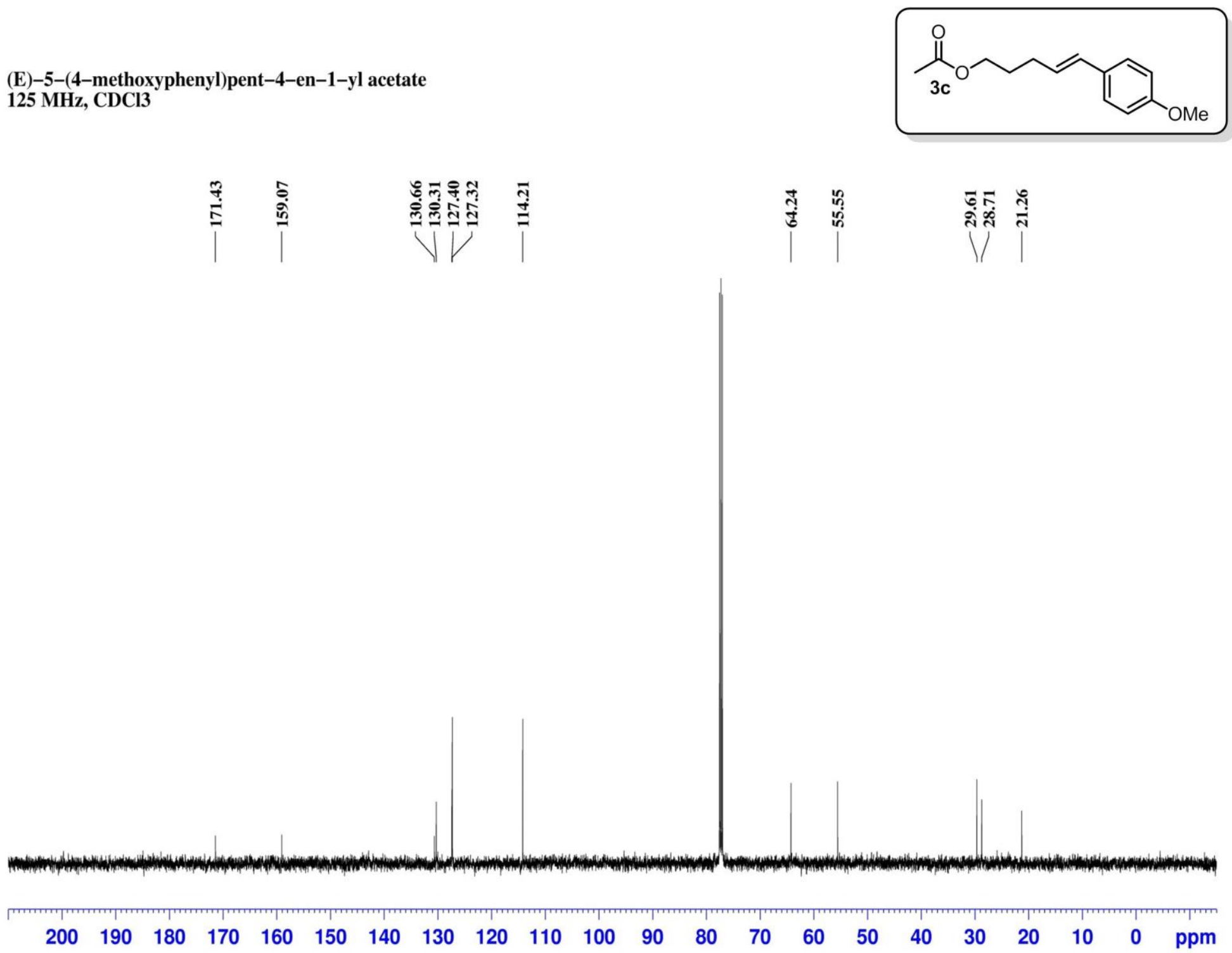
(E)-5-(4-chlorophenyl)pent-4-en-1-yl acetate $125 \mathrm{MHz}, \mathrm{CDCl}_{3}$
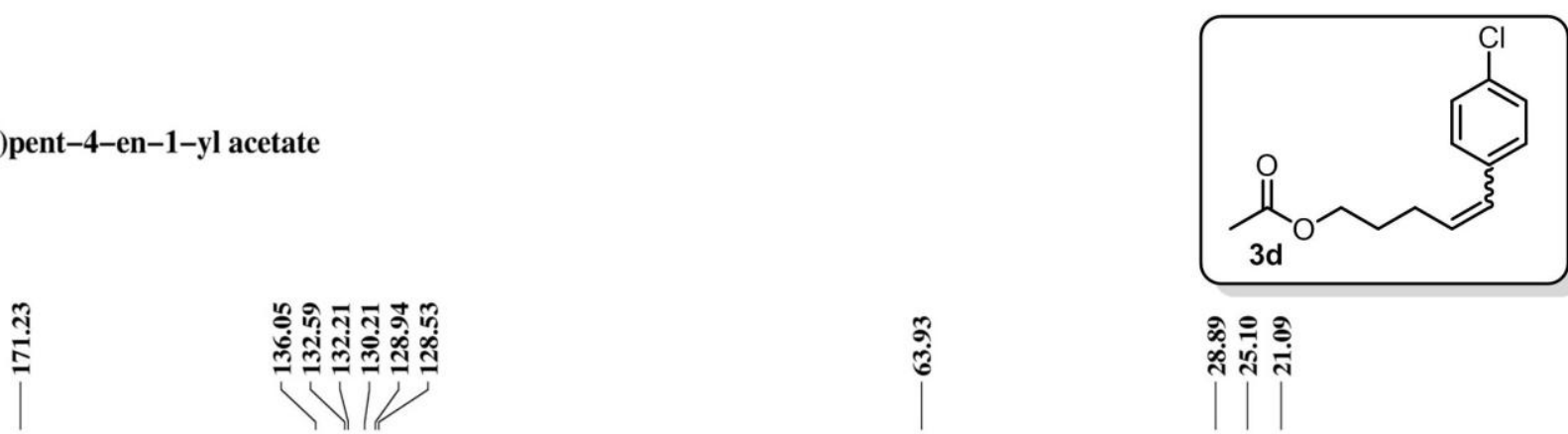

के कें केष

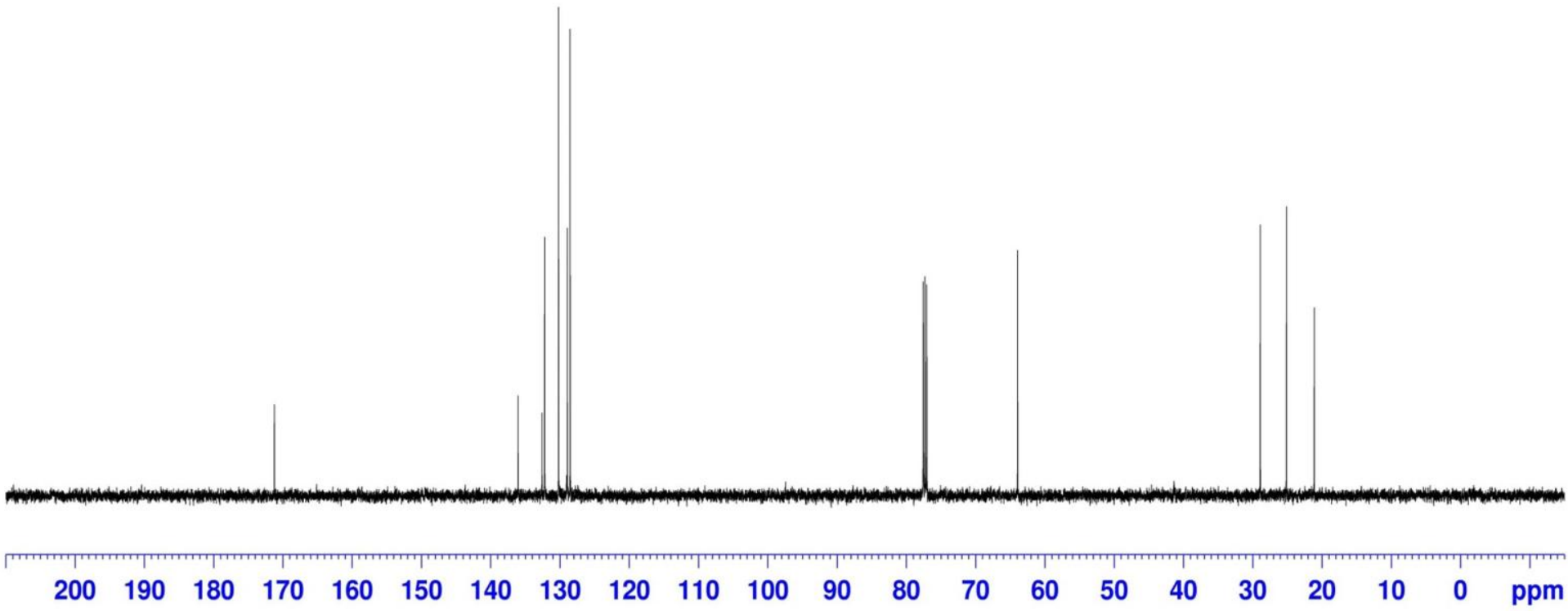


3-(1H-inden-2-yl)propyl acetate $125 \mathrm{MHz}, \mathrm{CDCl} 3$
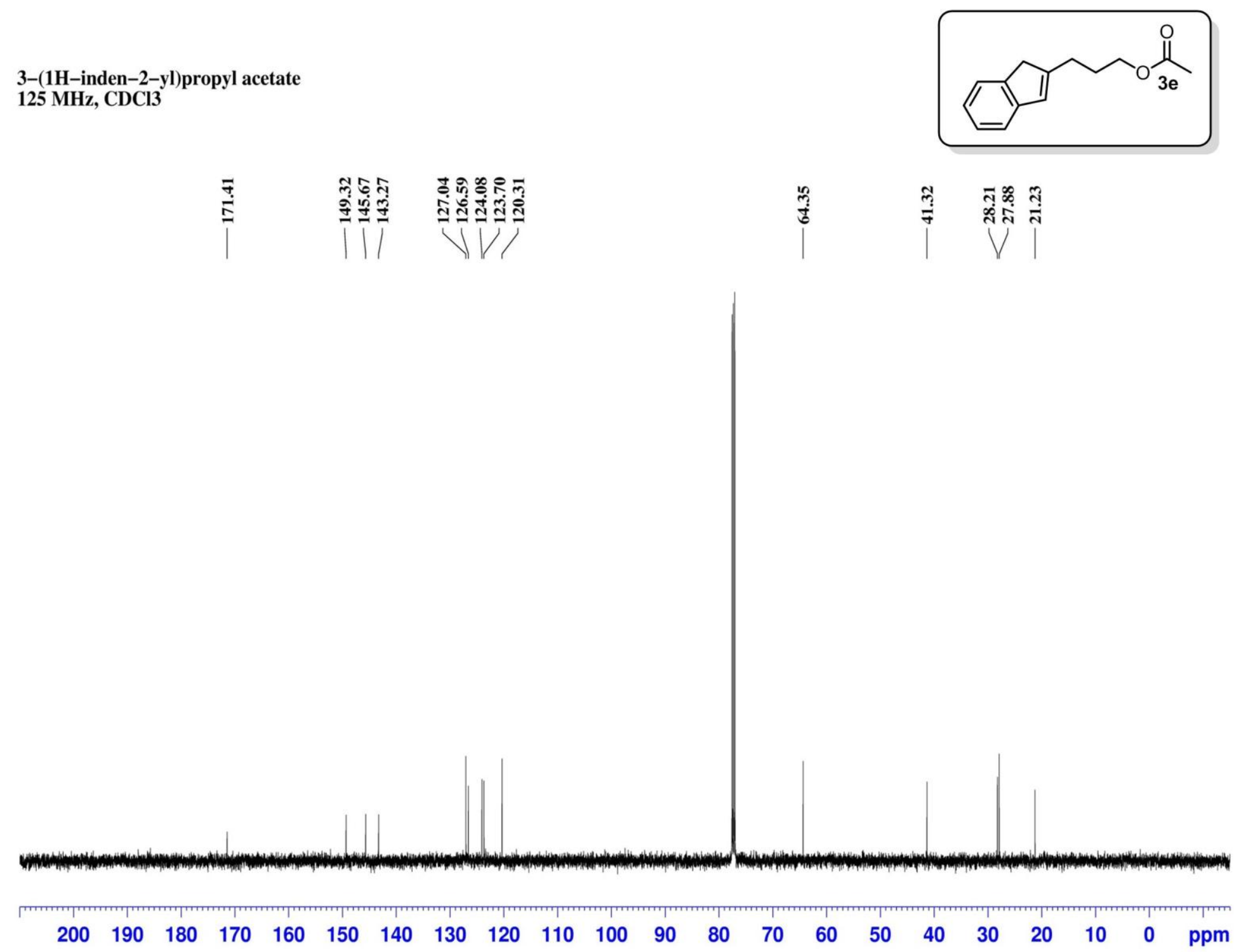
(Z)-ethyl 6-acetoxyhex-2-enoate $125 \mathrm{MHz}, \mathrm{CDCl} 3$
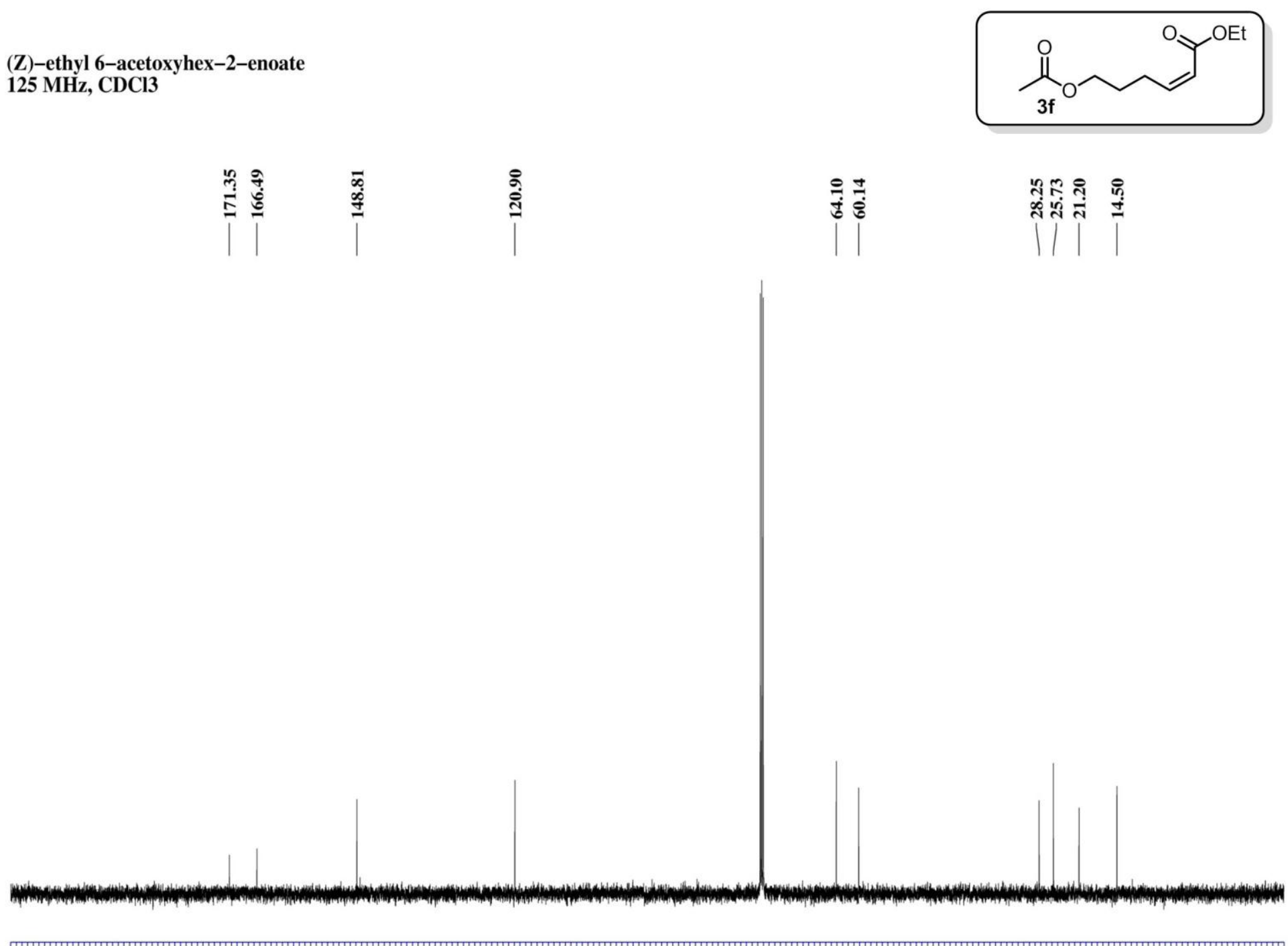

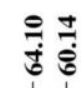

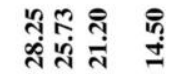

$\begin{array}{llllllllllllllllllllllll}200 & 190 & 180 & 170 & 160 & 150 & 140 & 130 & 120 & 110 & 100 & 90 & 80 & 70 & 60 & 50 & 40 & 30 & 20 & 10 & 0 & \text { ppm }\end{array}$ 
(E)-3-(cyclooct-1-en-1-yl)propyl acetate $125 \mathrm{MHz}, \mathrm{CDCl} 3$
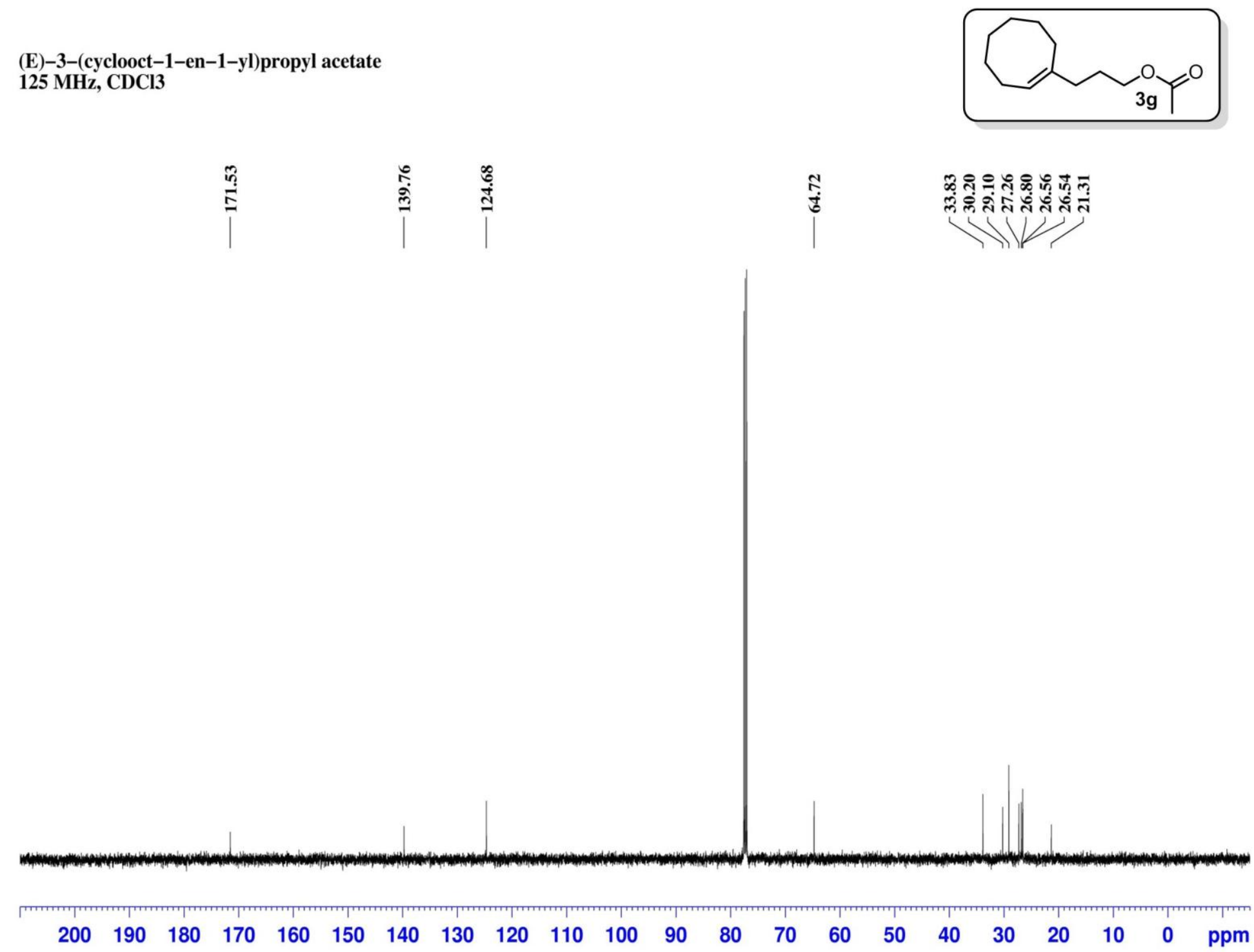
4-cyclohexylidenebutyl acetate $125 \mathrm{MHz}$, CDCl3
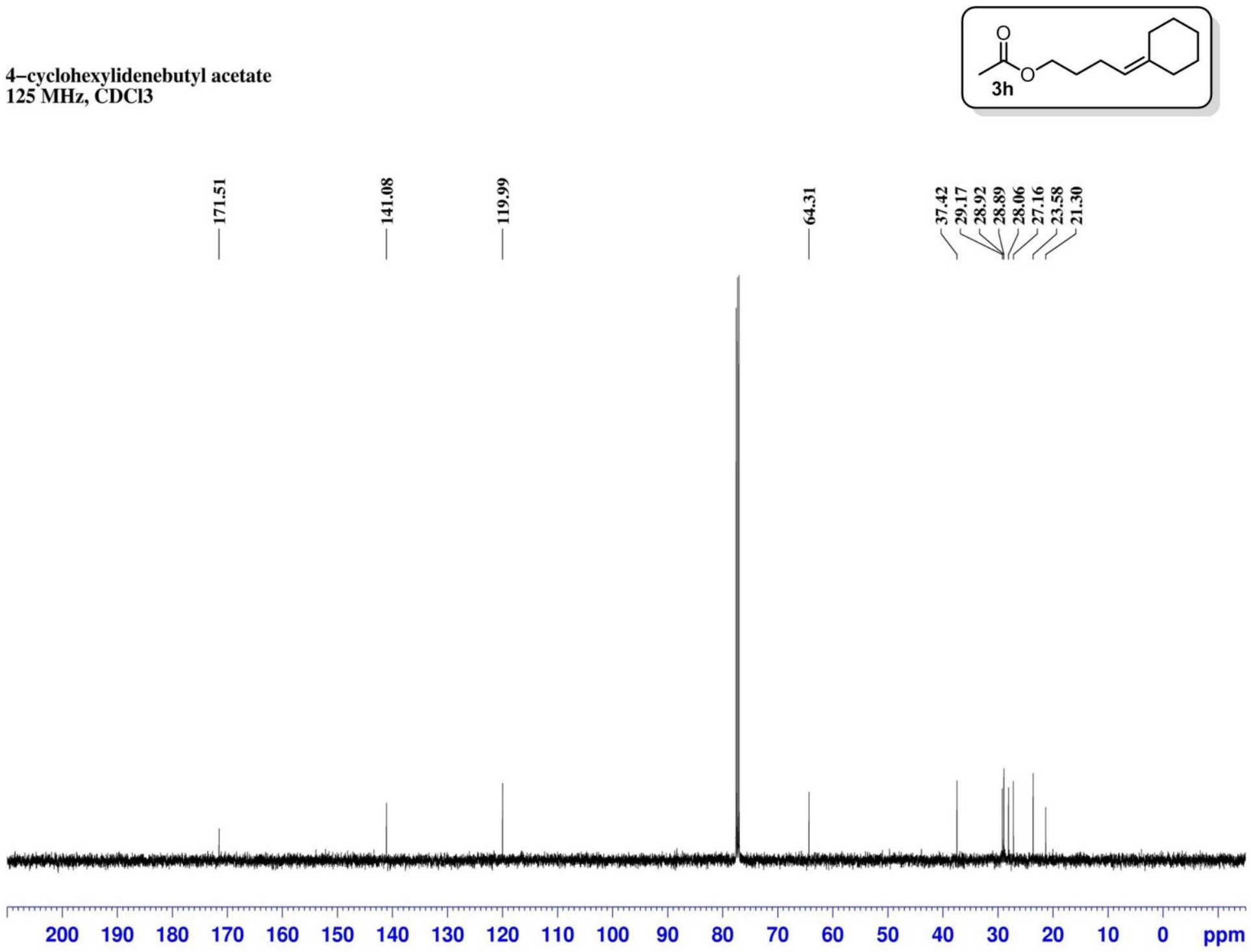
5-methylhex-4-en-1-yl acetate $125 \mathrm{MHz}, \mathrm{CDCl} 3$
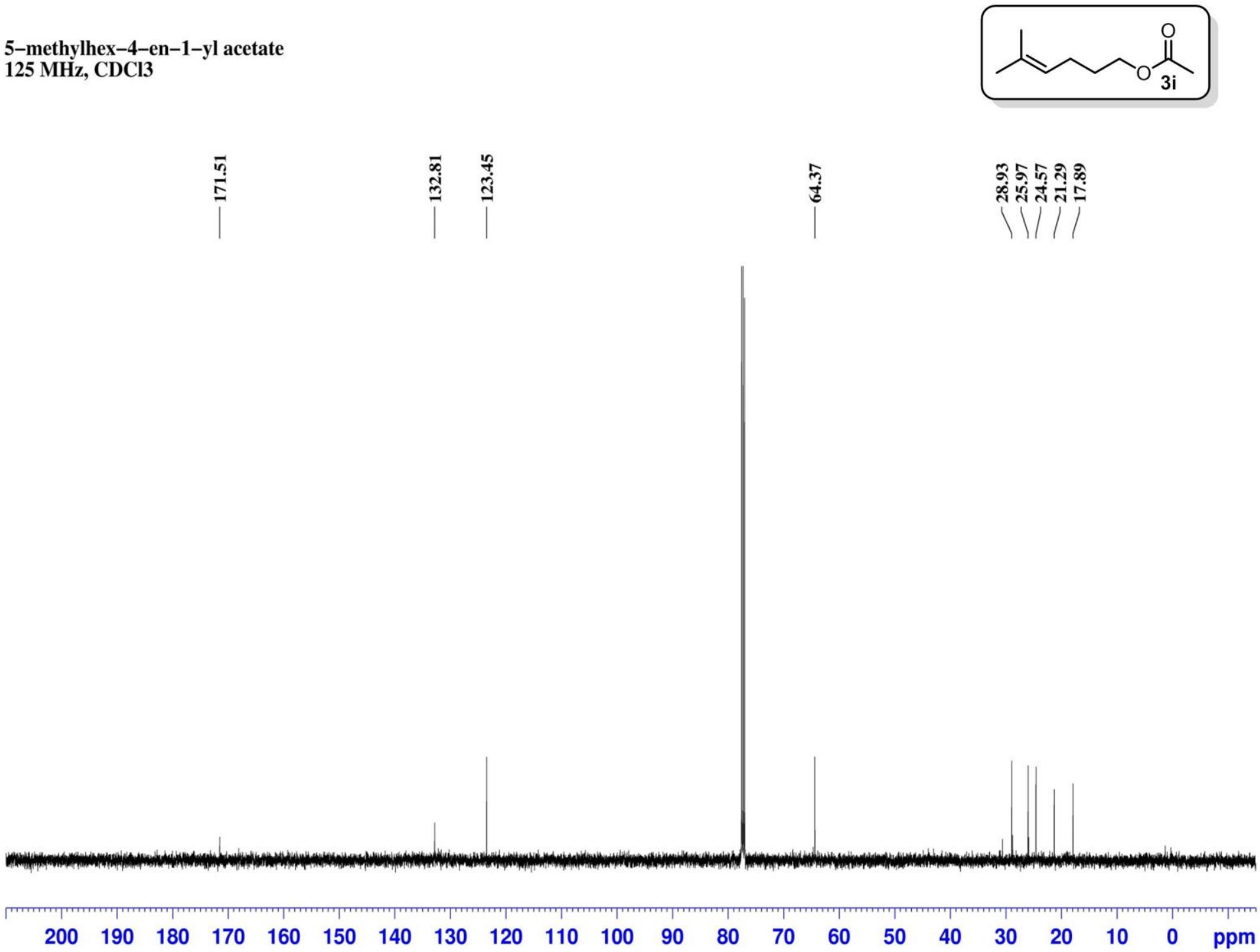
(Z)-6-((tert-butyldimethylsilyl)oxy)hex-4-en-1-yl acetate $125 \mathrm{MHz}, \mathrm{CDCl} 3$
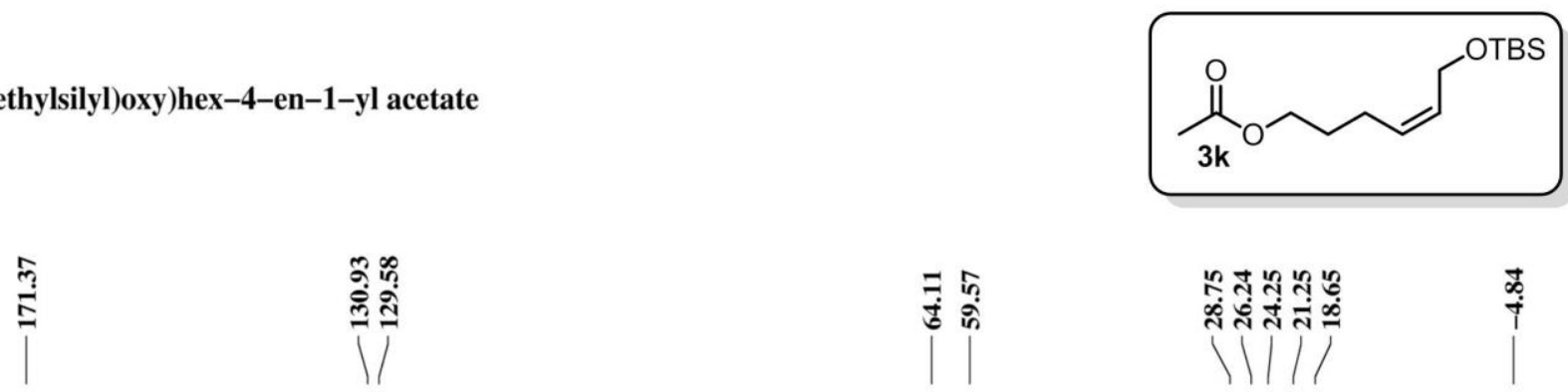

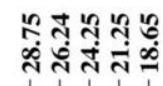

$\stackrel{\overrightarrow{+}+}{+}$

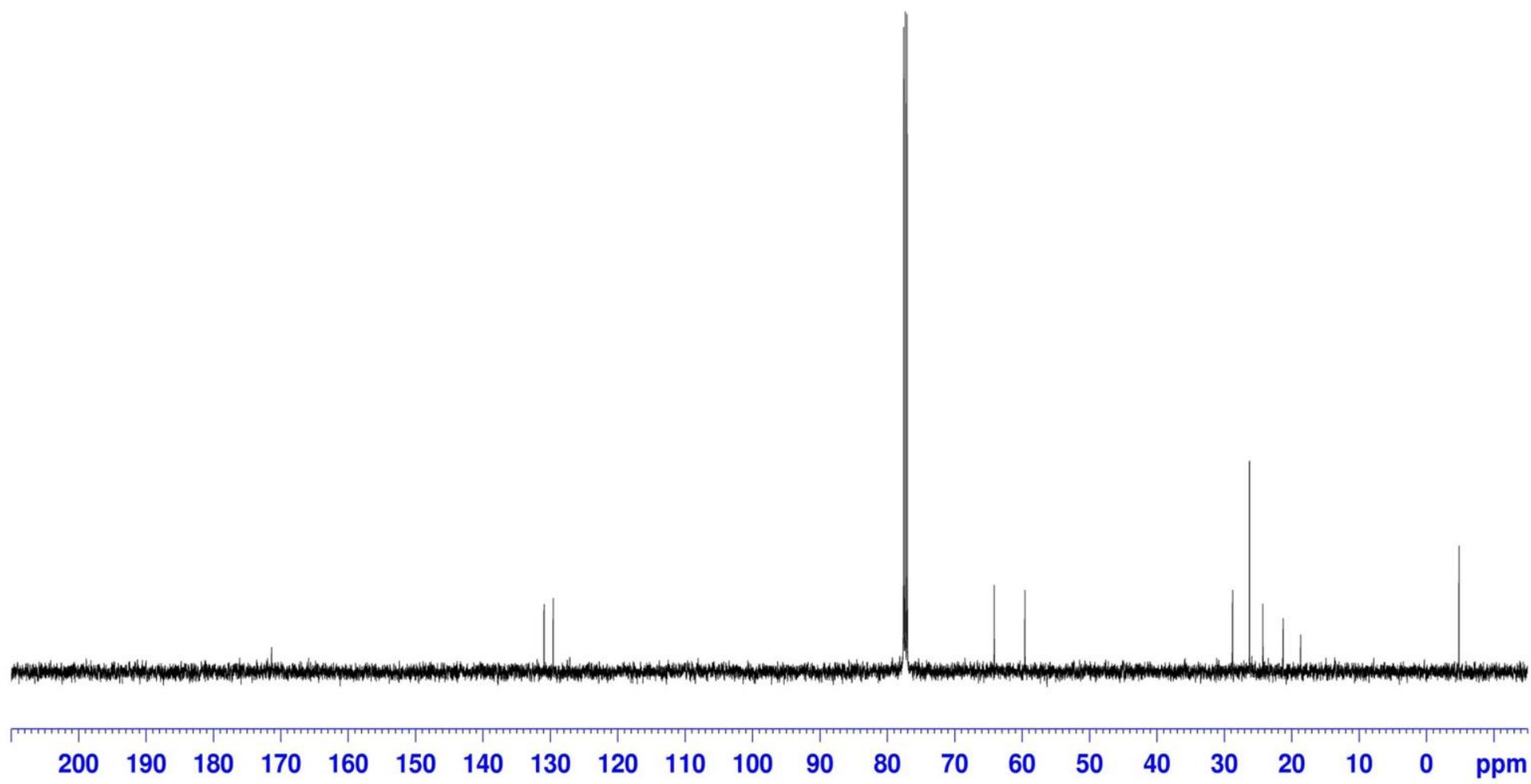




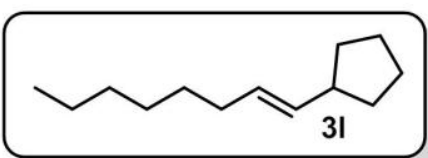

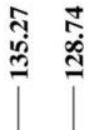

ป็๊
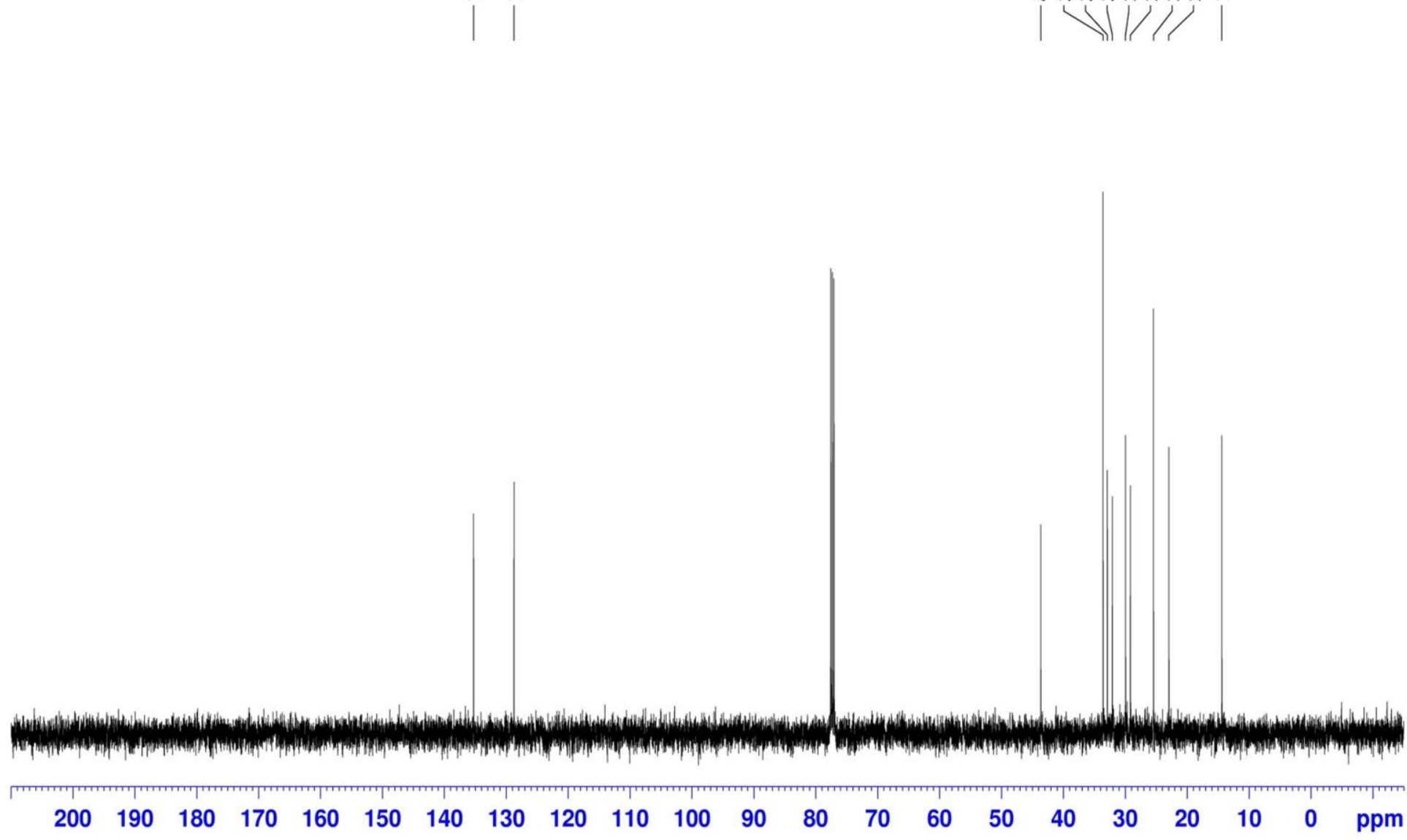
(E)-oct-1-en-1-ylcyclohexane

$125 \mathrm{MHz}, \mathrm{CDCl} 3$

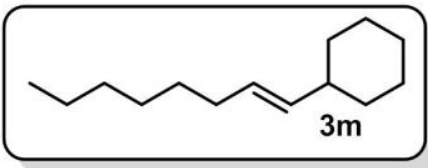

|

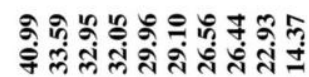

Mlll

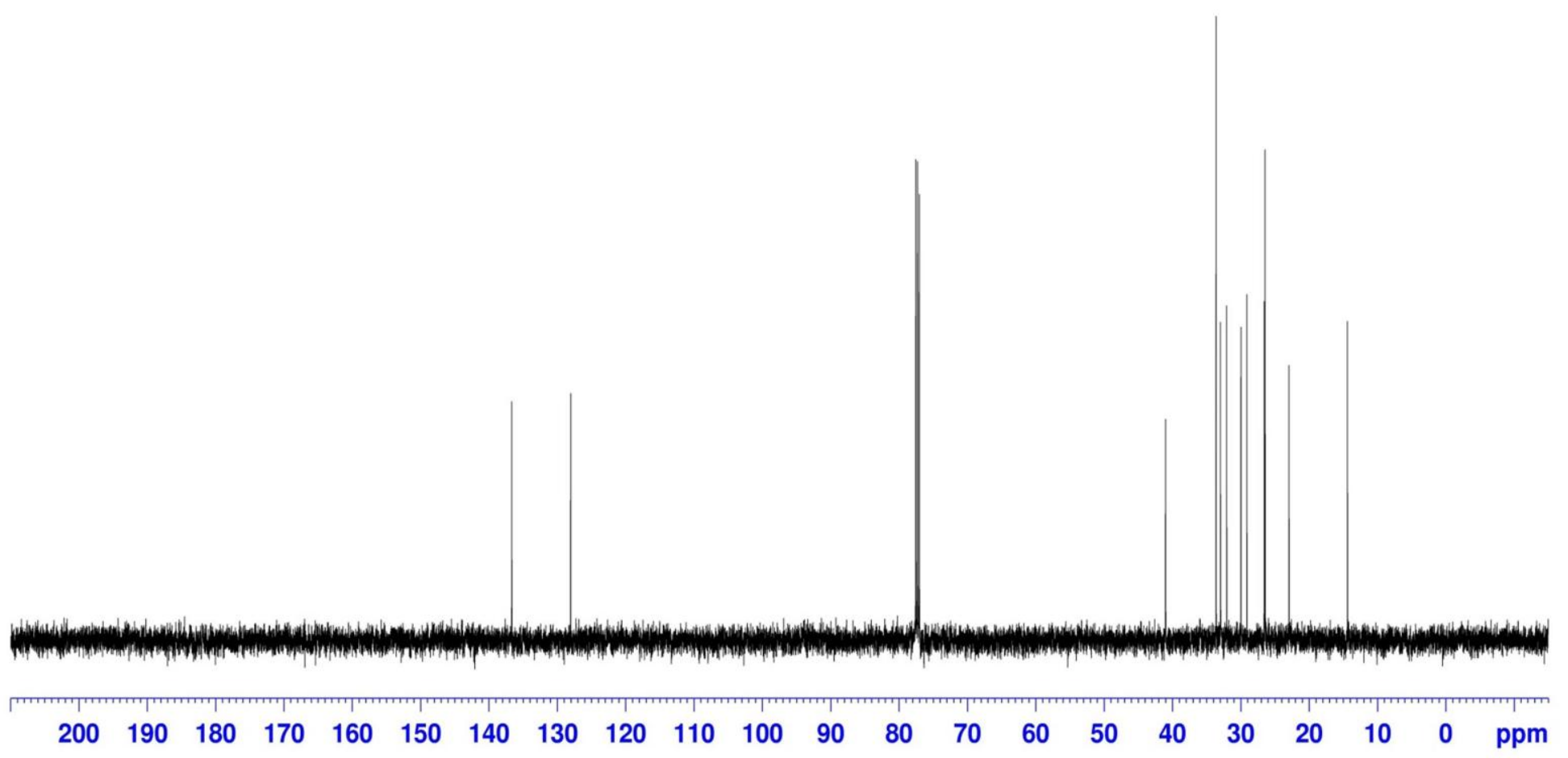


(E)-2-(oct-1-en-1-yl)bicyclo[2.2.1] heptane

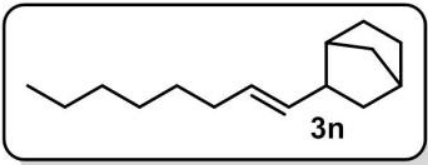

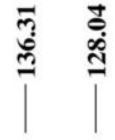

\section{7ิธ}

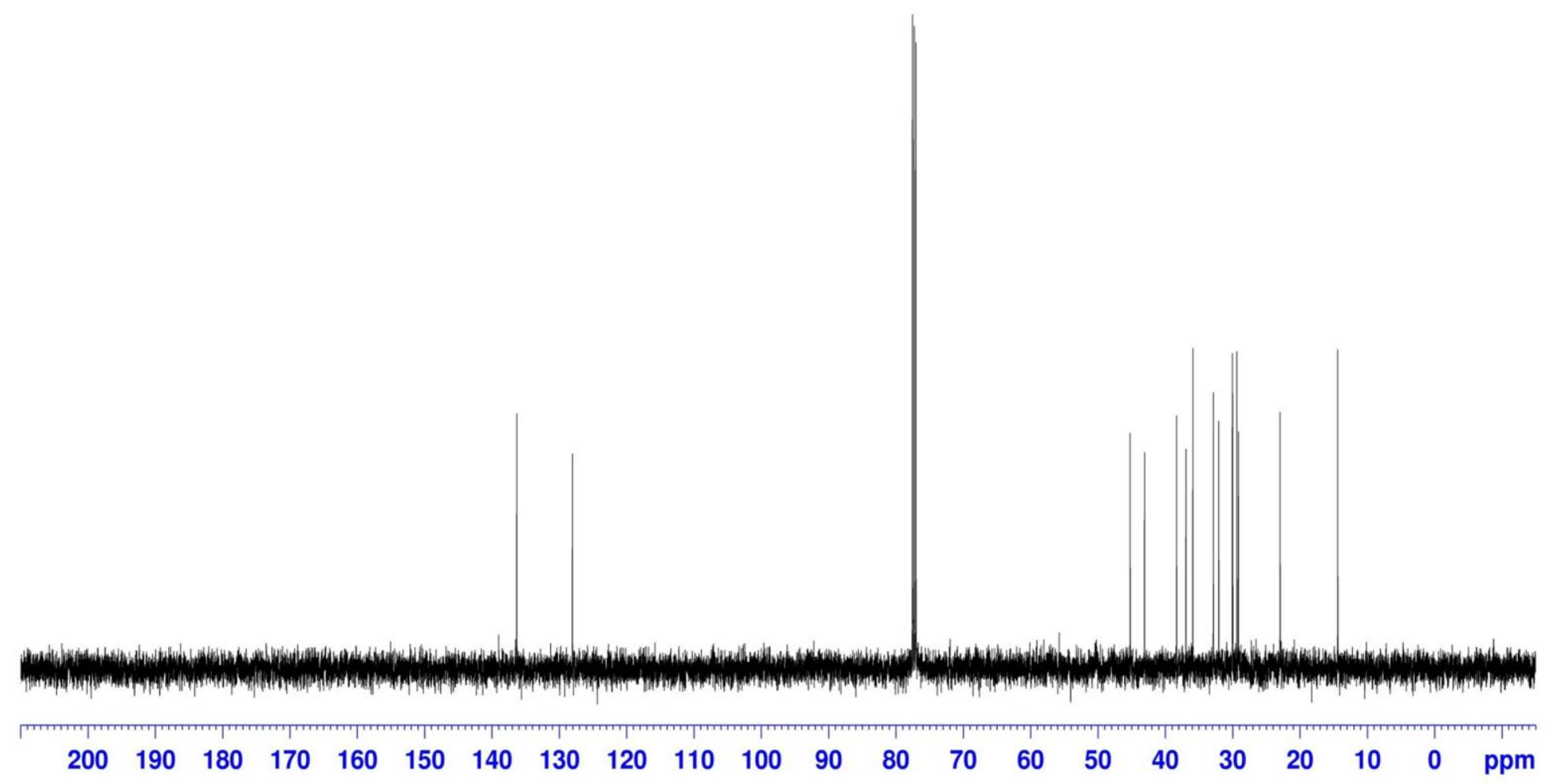



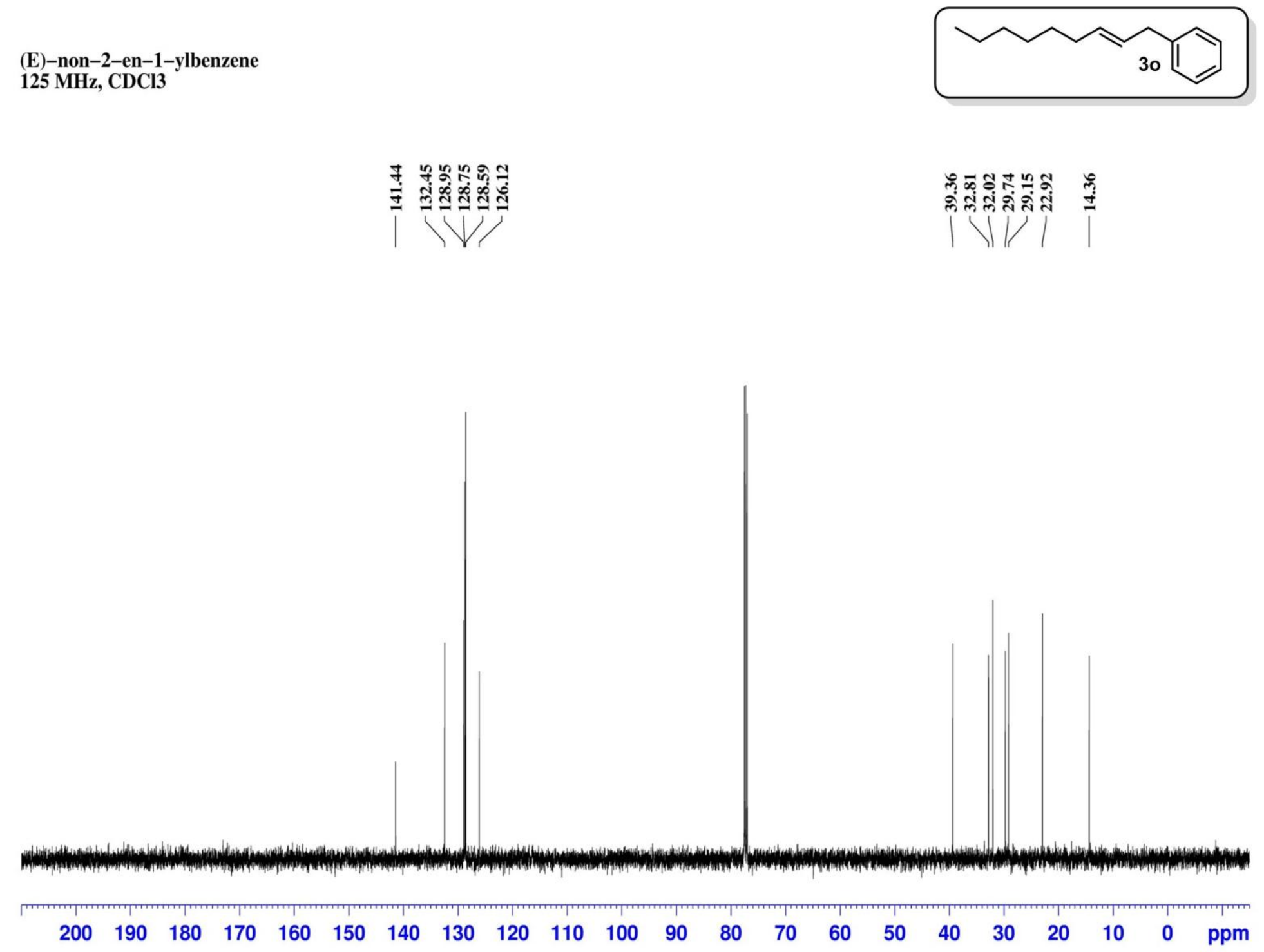
(E)-undeca-1,4-diene

$125 \mathrm{MHz}, \mathrm{CDCl} 3$
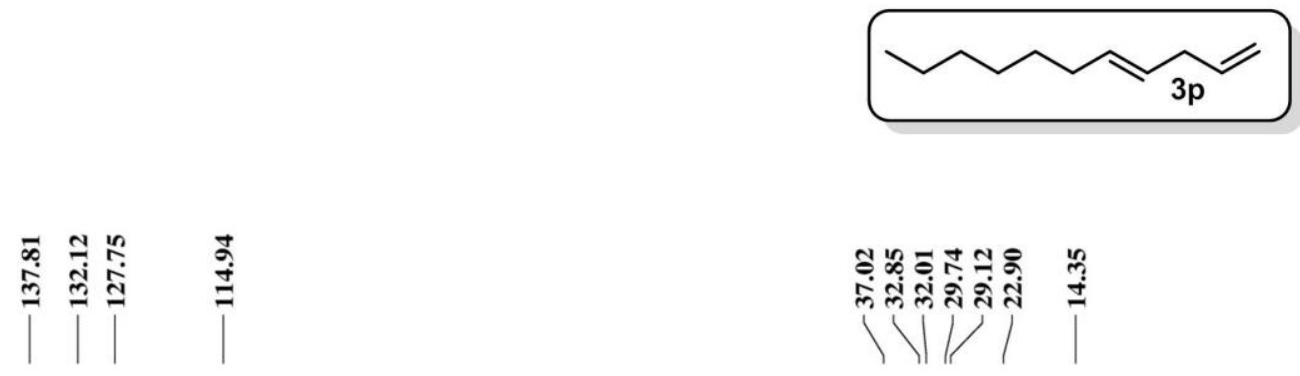

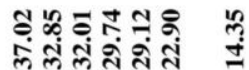

1111

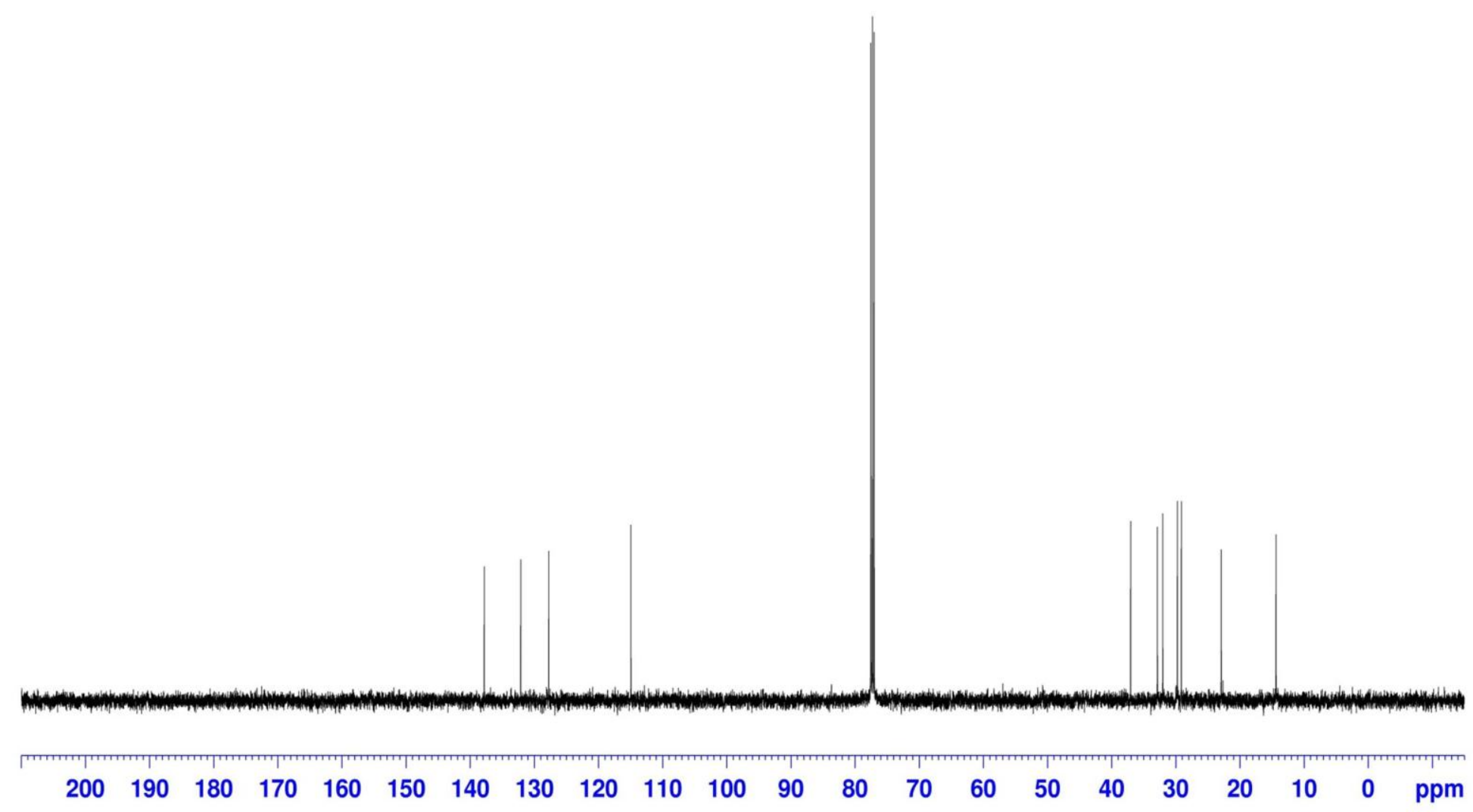



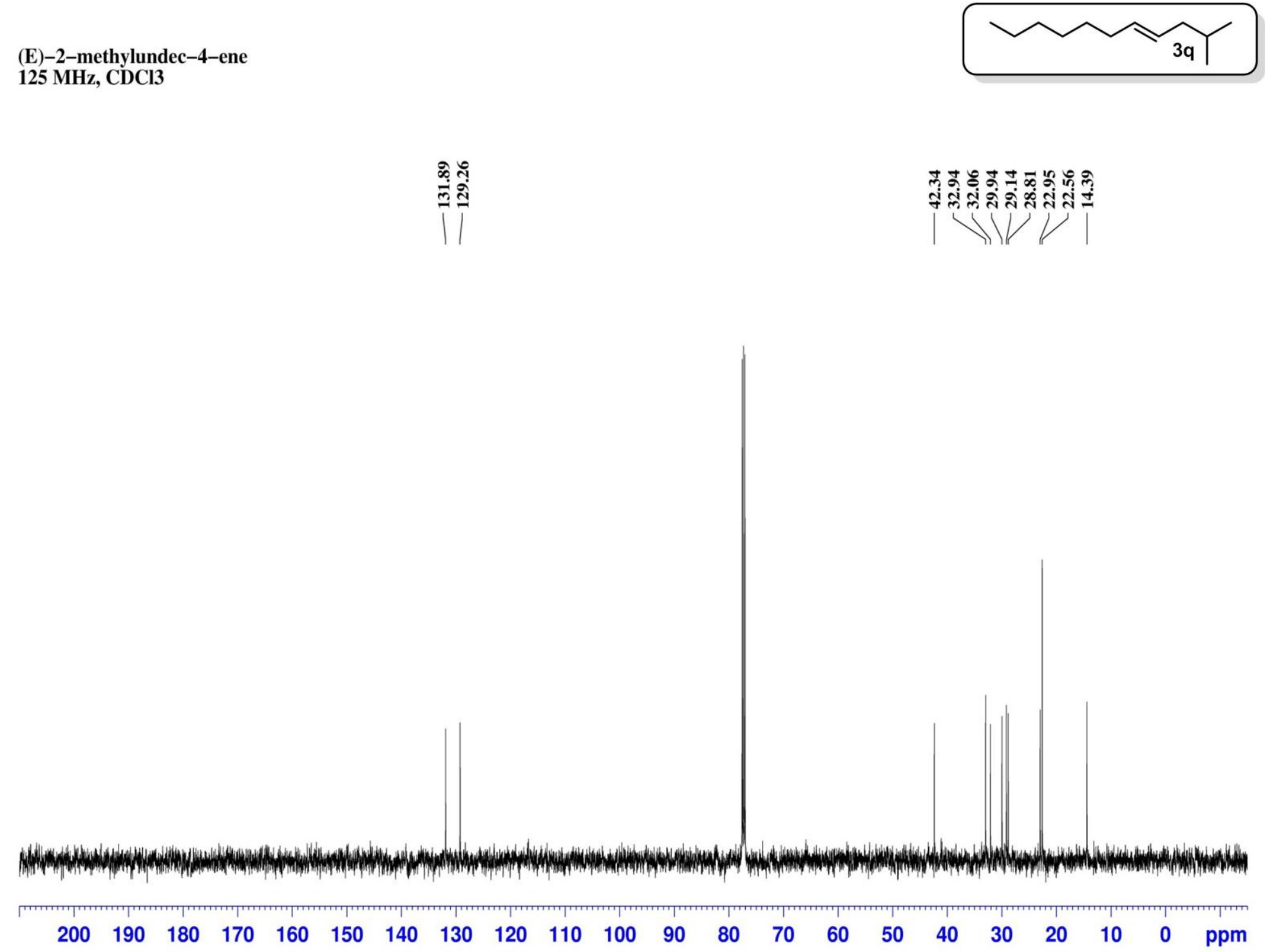
(E)-4-(dec-3-en-1-yl)cyclohex-1-ene $125 \mathrm{MHz}, \mathrm{CDCl} 3$

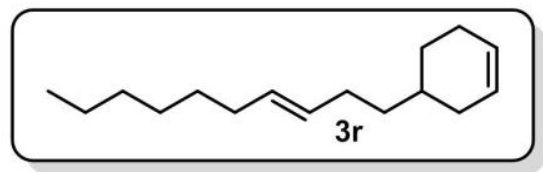

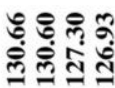

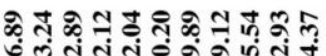

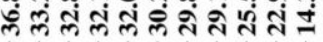

(

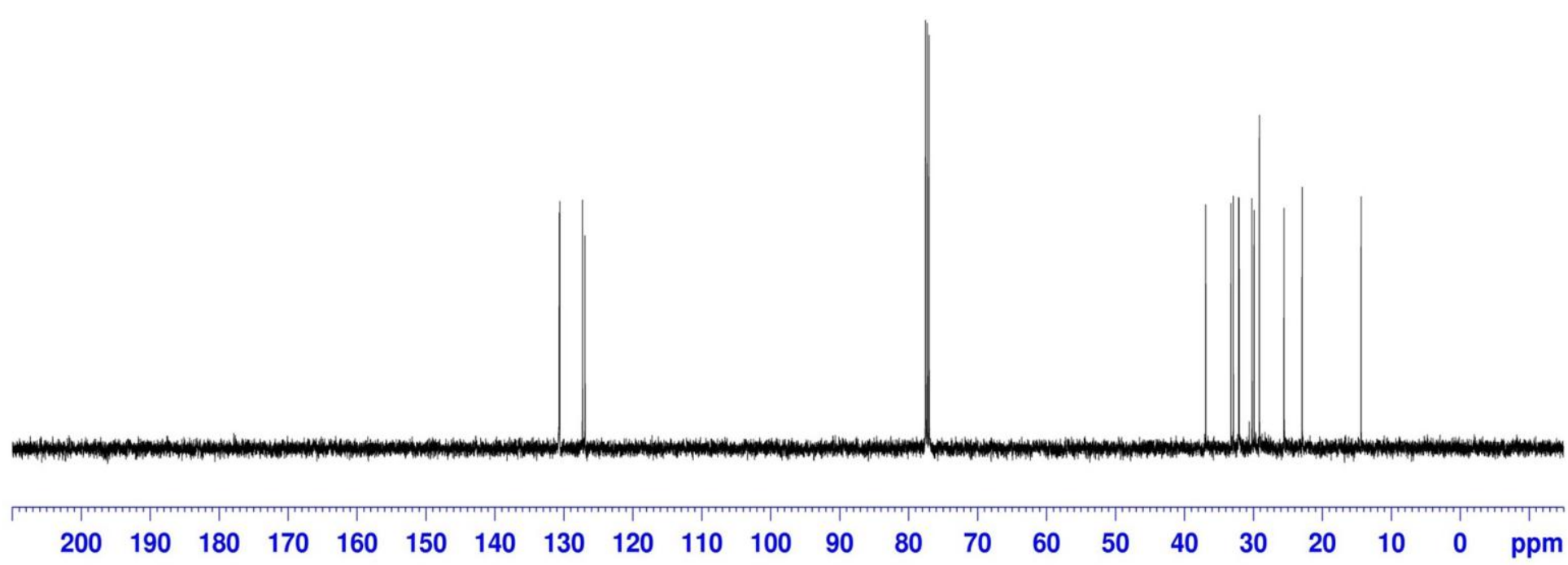


(E)-tetradec-7-ene

$125 \mathrm{MHz}, \mathrm{CDCl} 3$
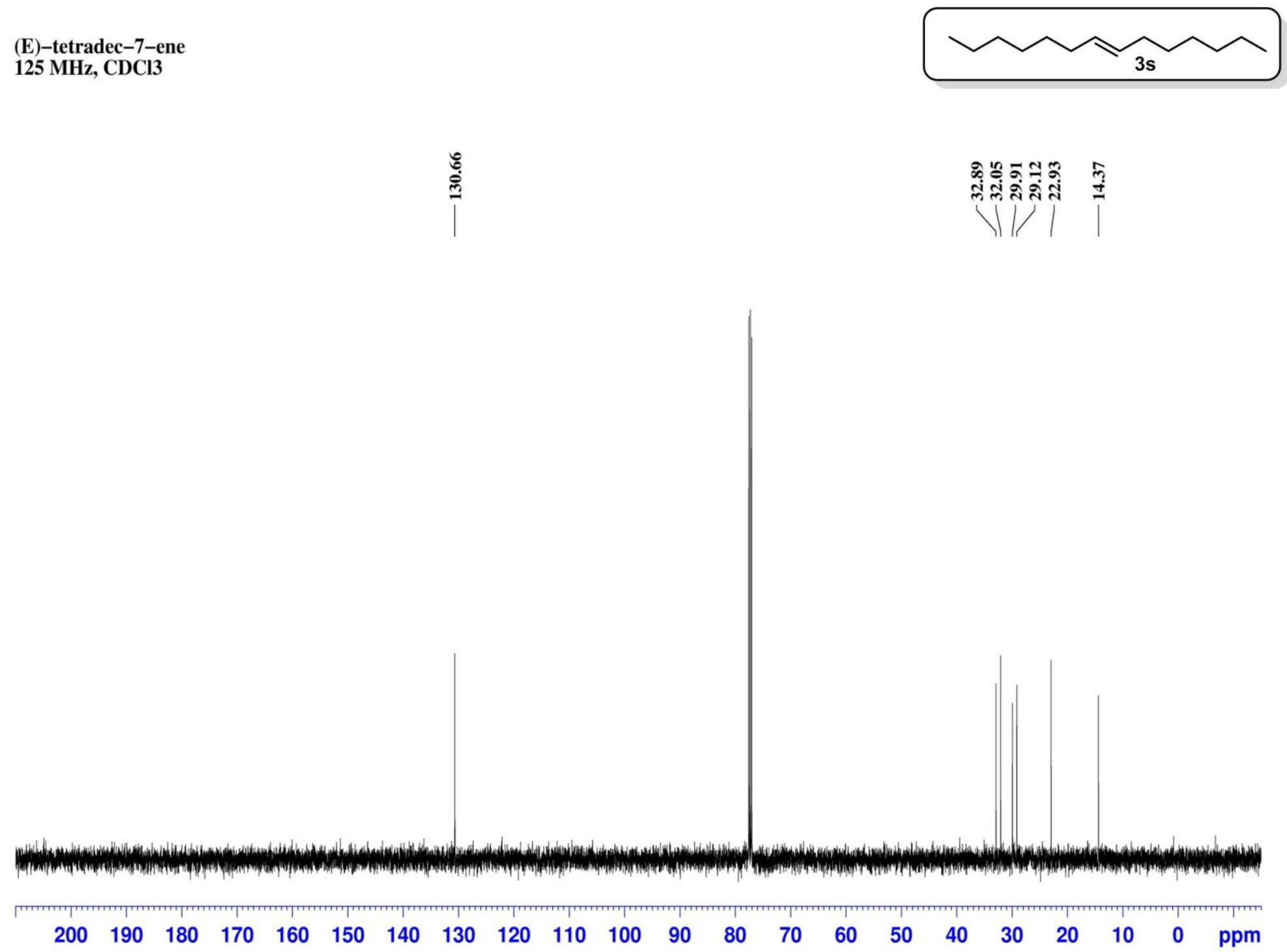
(E)-1-methoxyundec-4-ene

$125 \mathrm{MHz}, \mathrm{CDCl} 3$
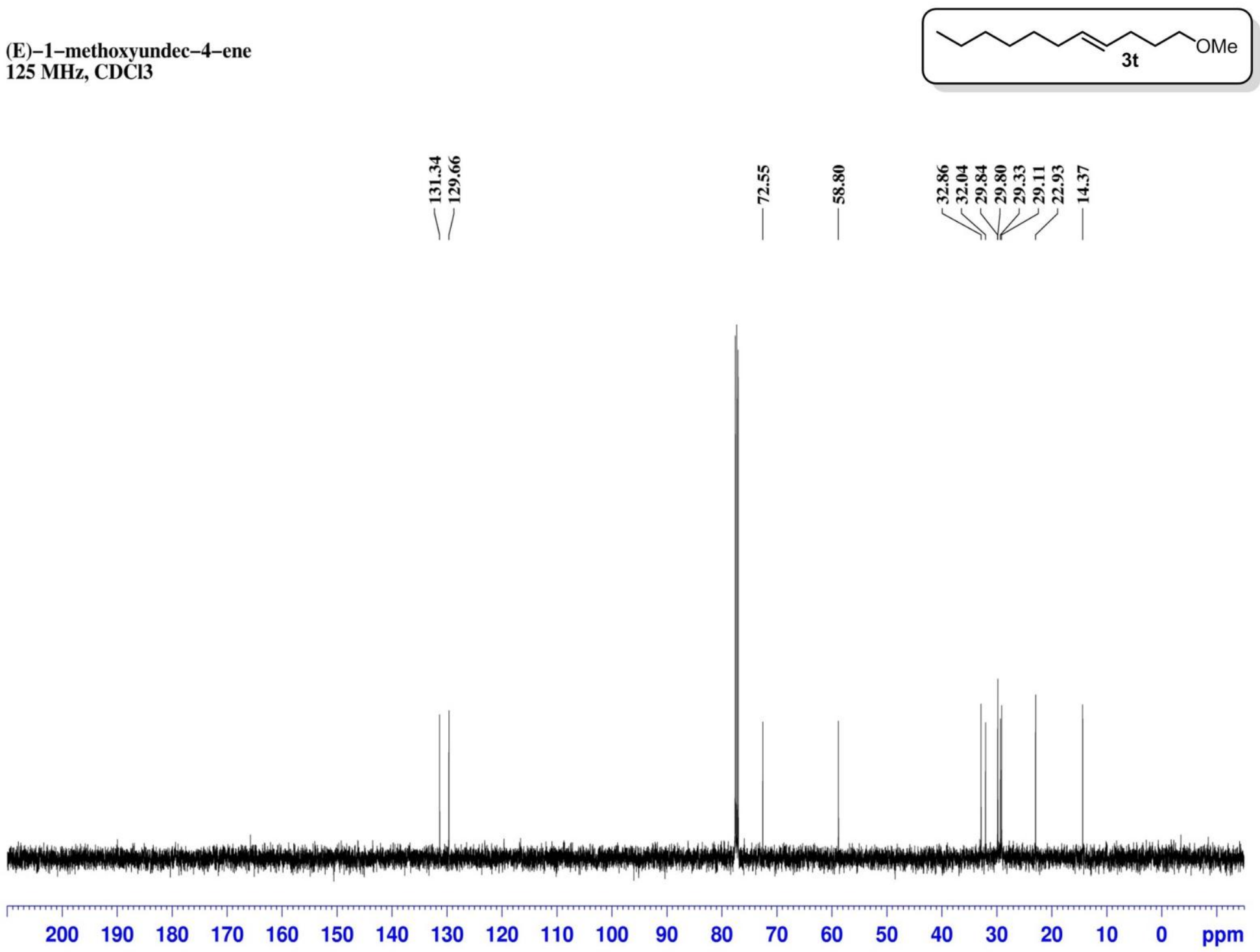
(E)-N-(undec-4-en-1-yl)acetamide

$125 \mathrm{MHz}, \mathrm{CDCl} 3$
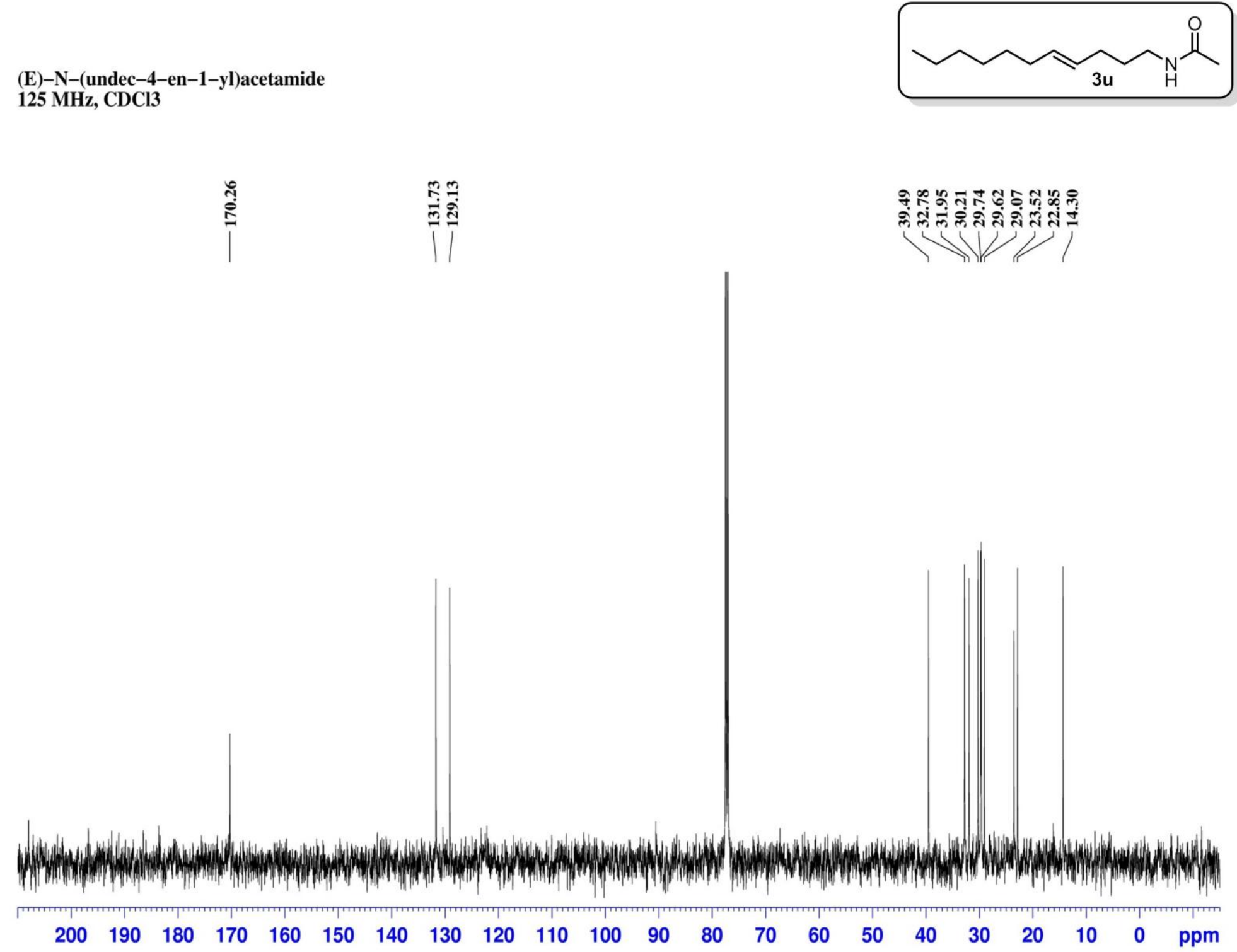
(E)-2-(dec-3-en-1-yl)pyridine

$125 \mathrm{MHz}, \mathrm{CDCl} 3$

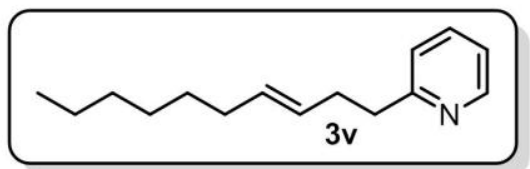

|

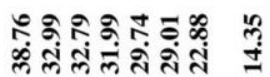

W/II

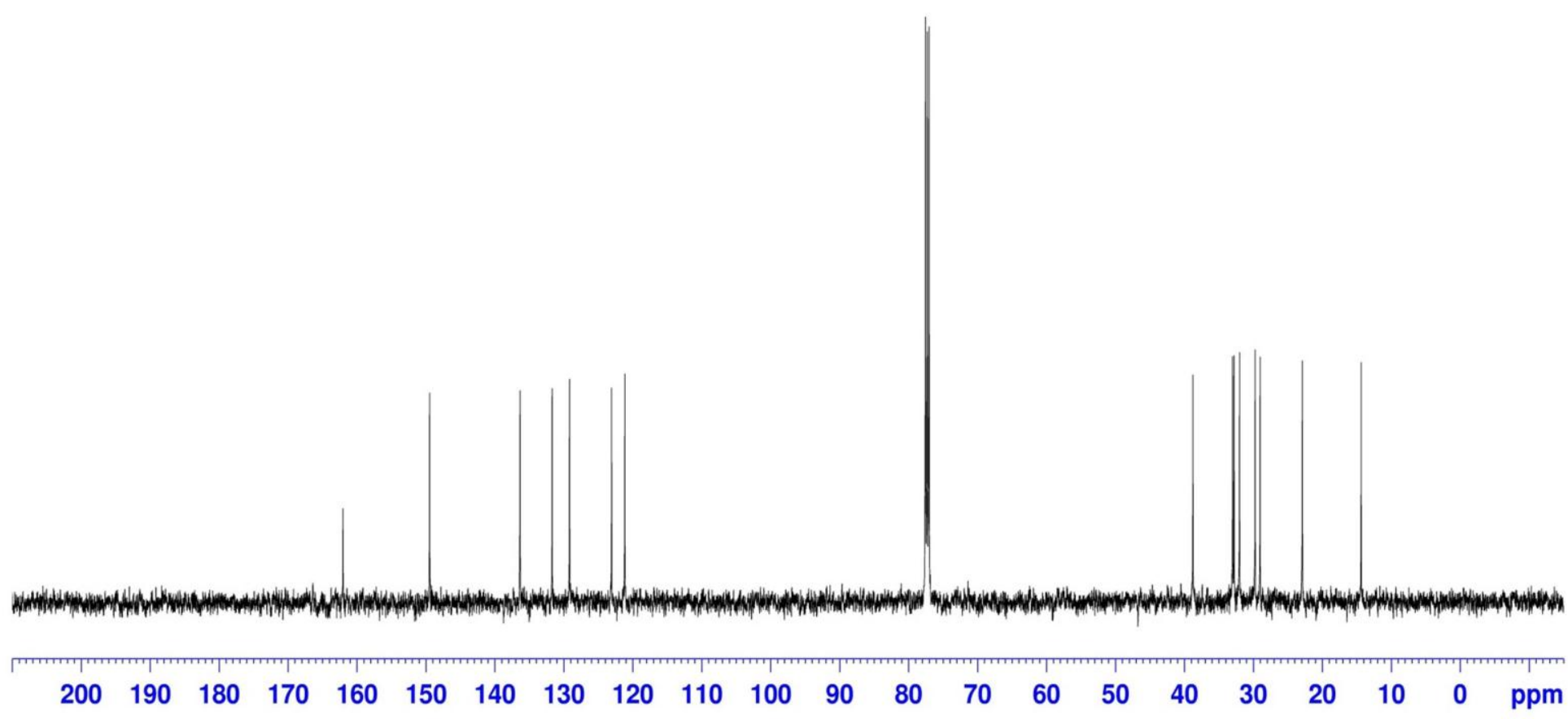


(E)-undec-4-en-1-amine $125 \mathrm{MHz}, \mathrm{CDCl} 3$
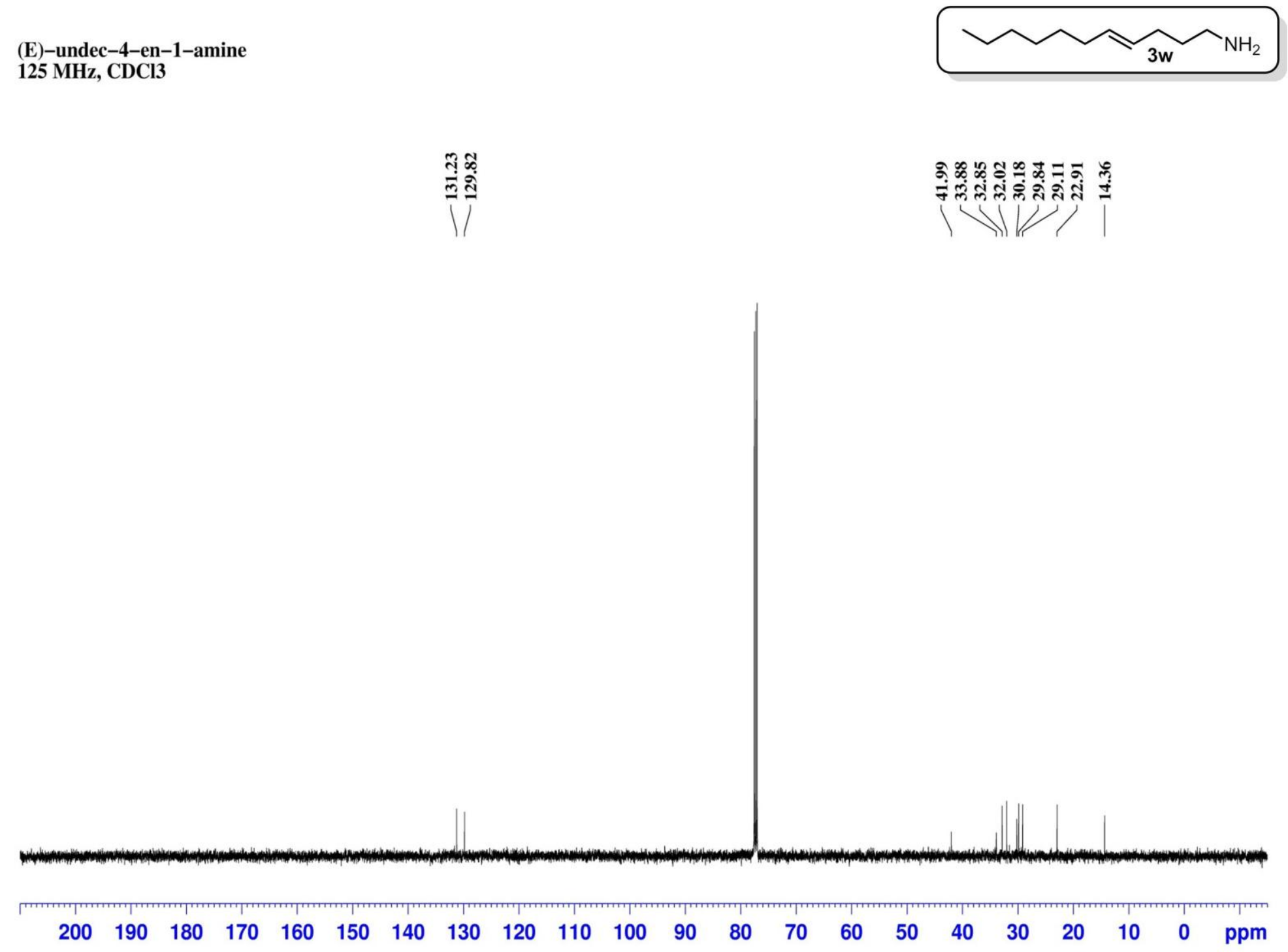
(E)-1-benzylcyclooct-1-ene

$125 \mathrm{MHz}, \mathrm{CDCl} 3$
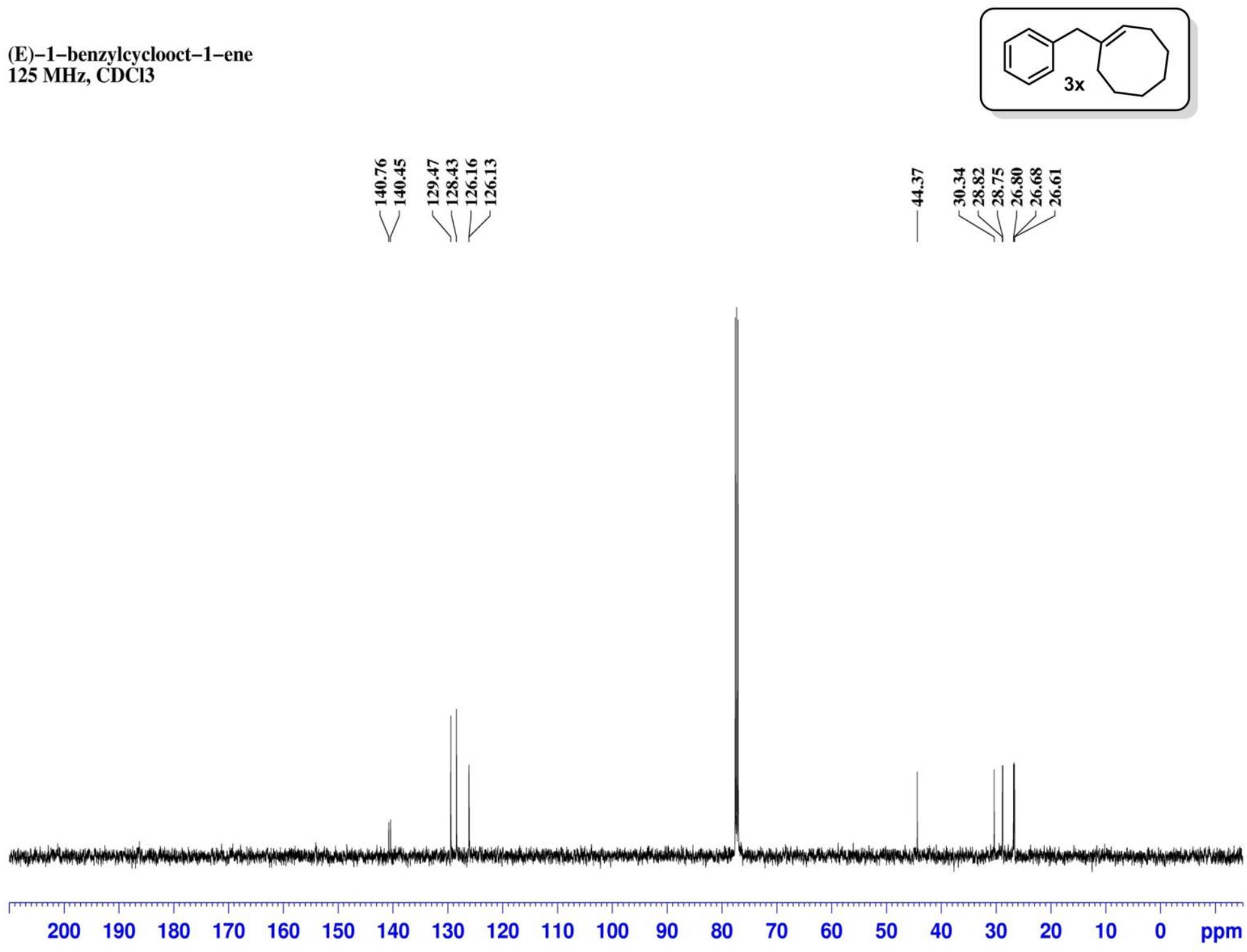
(E)-1-(2-(cyclohex-3-en-1-yl)ethyl)cyclooct-1-ene $125 \mathrm{MHz}, \mathrm{CDCl} 3$
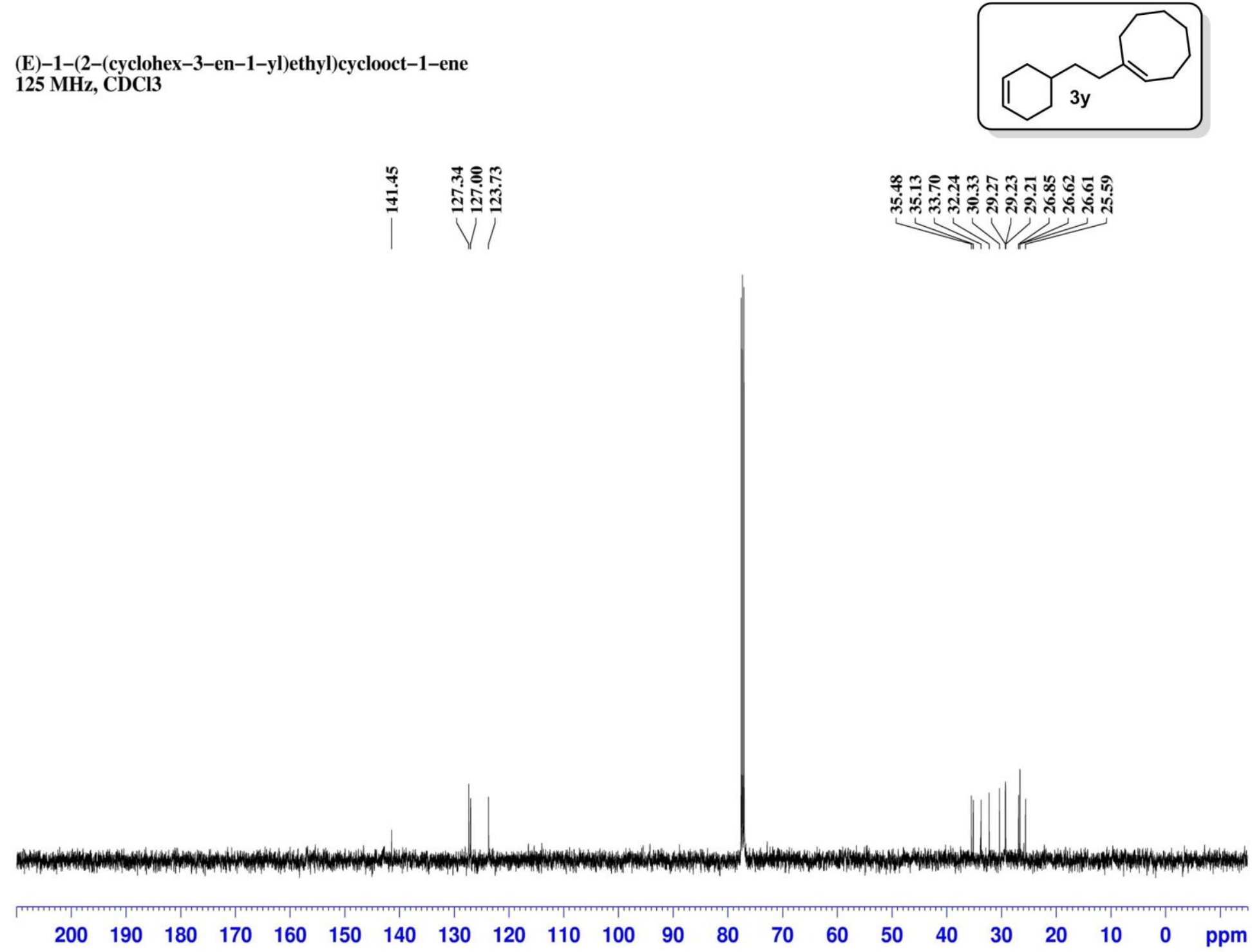
(E)-2-(cyclooct-1-en-1-yl)bicyclo[2.2.1] heptane $125 \mathrm{MHz}, \mathrm{CDCl} 3$
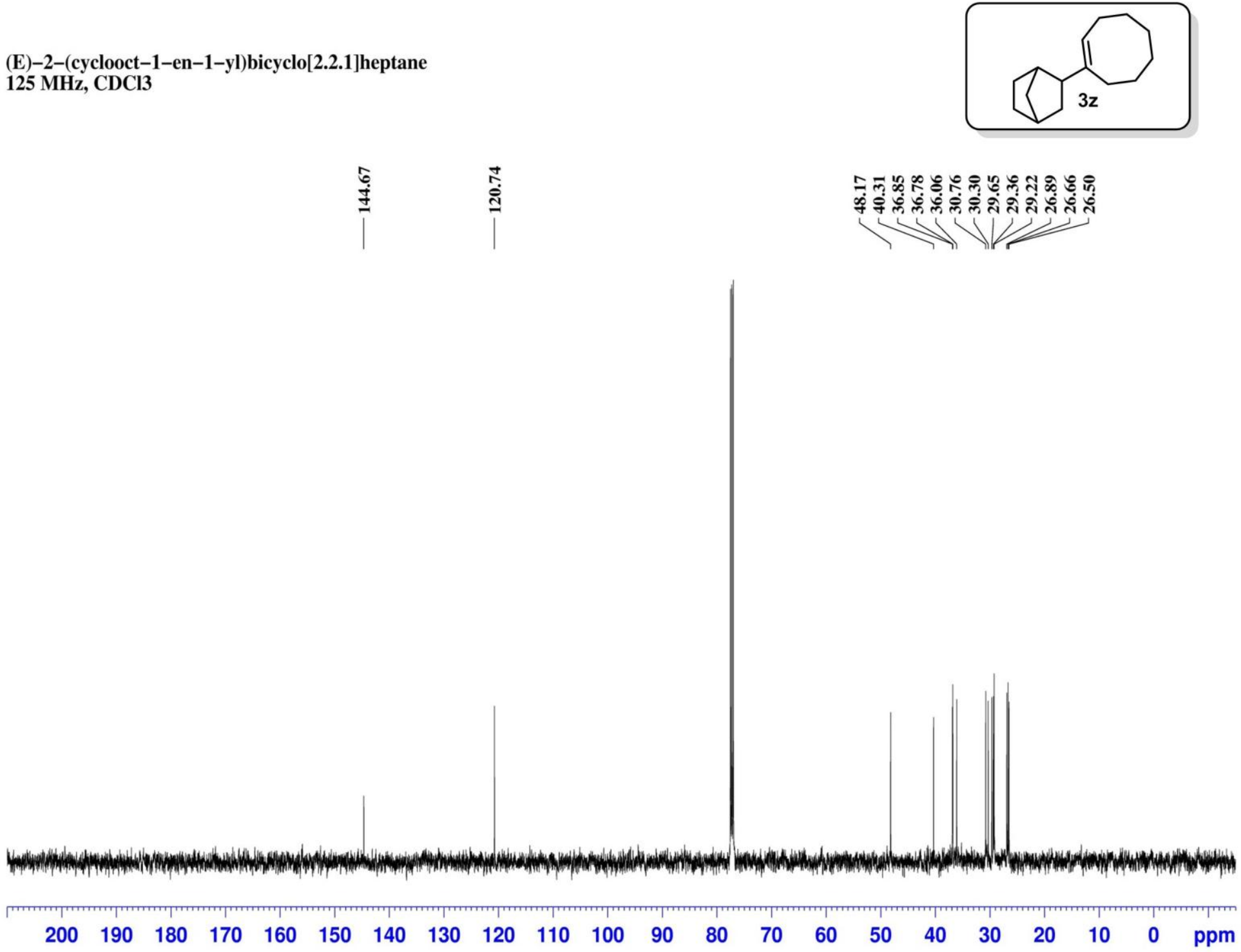
(E)-N-(3-(cyclooct-1-en-1-yl)propyl)acetamide $125 \mathrm{MHz}, \mathrm{CDCl} 3$
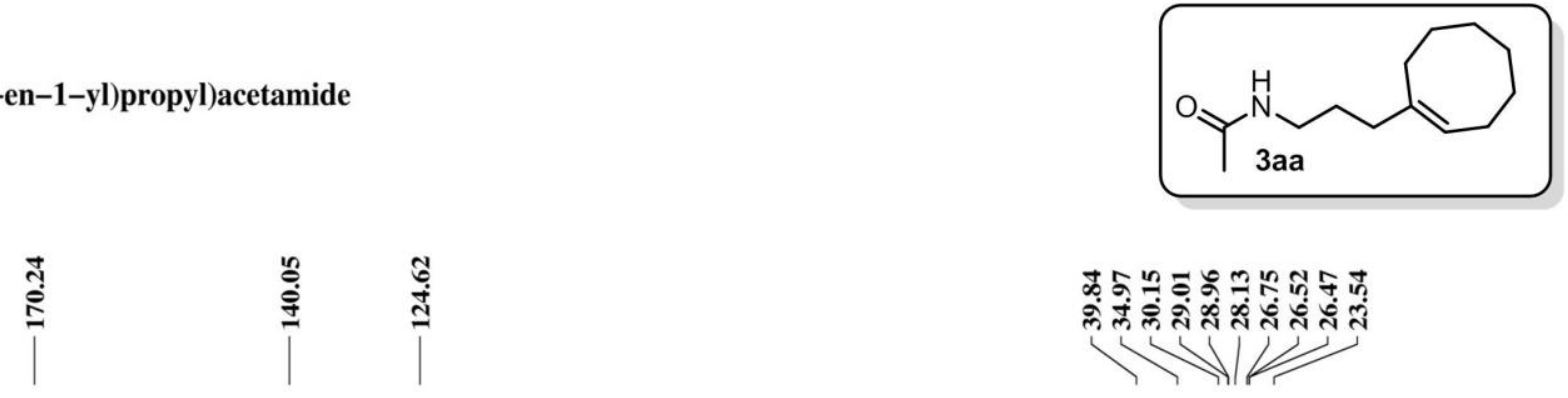

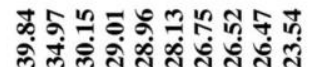

Non

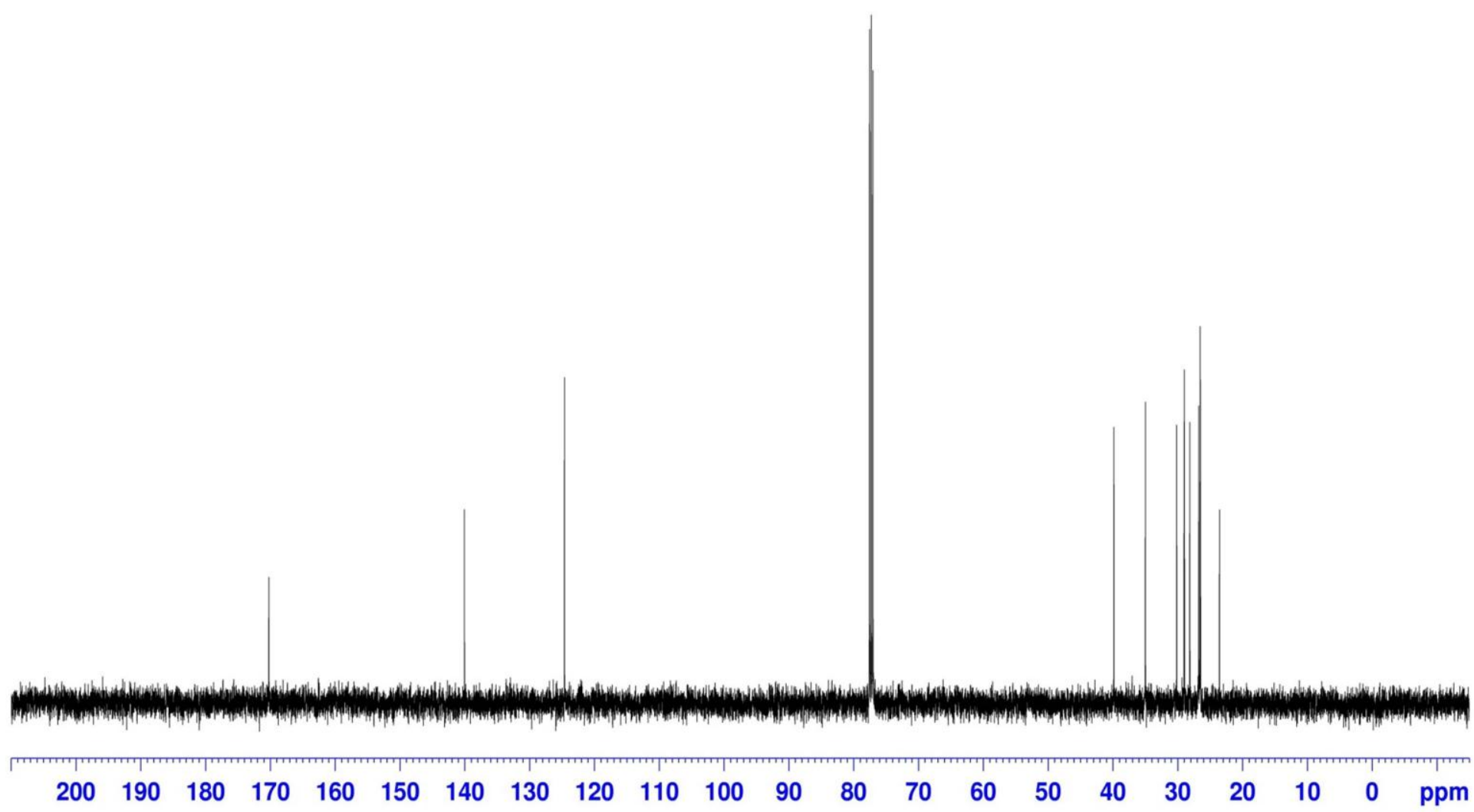


(E)-3-(cyclooct-1-en-1-yl)propan-1-amine

$125 \mathrm{MHz}, \mathrm{CDCl} 3$

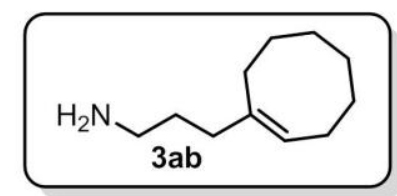

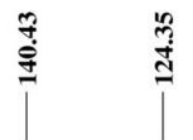

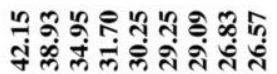

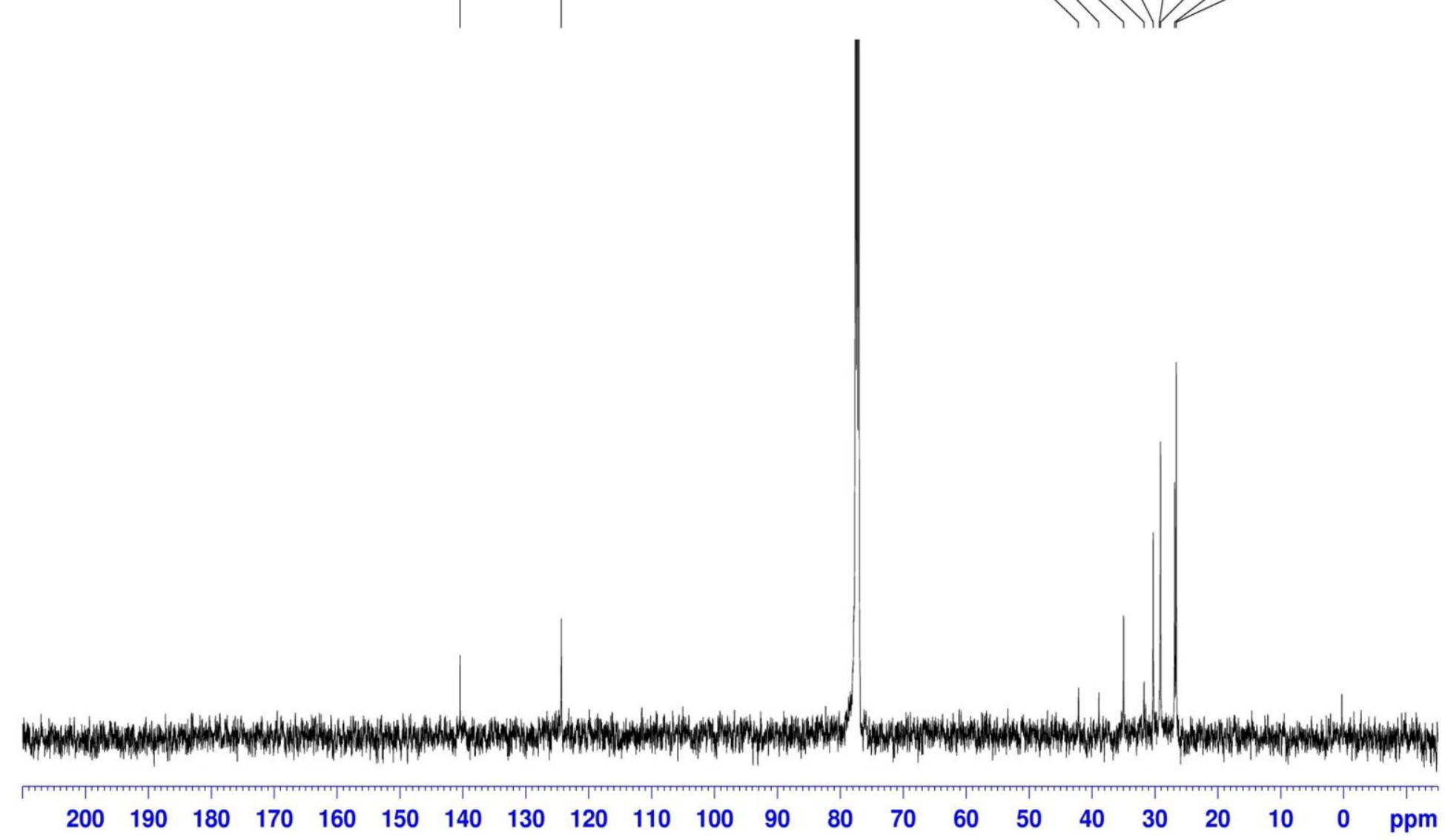


(Z)-ethyl 4-phenylbut-2-enoate $125 \mathrm{MHz}, \mathrm{CDCl} 3$
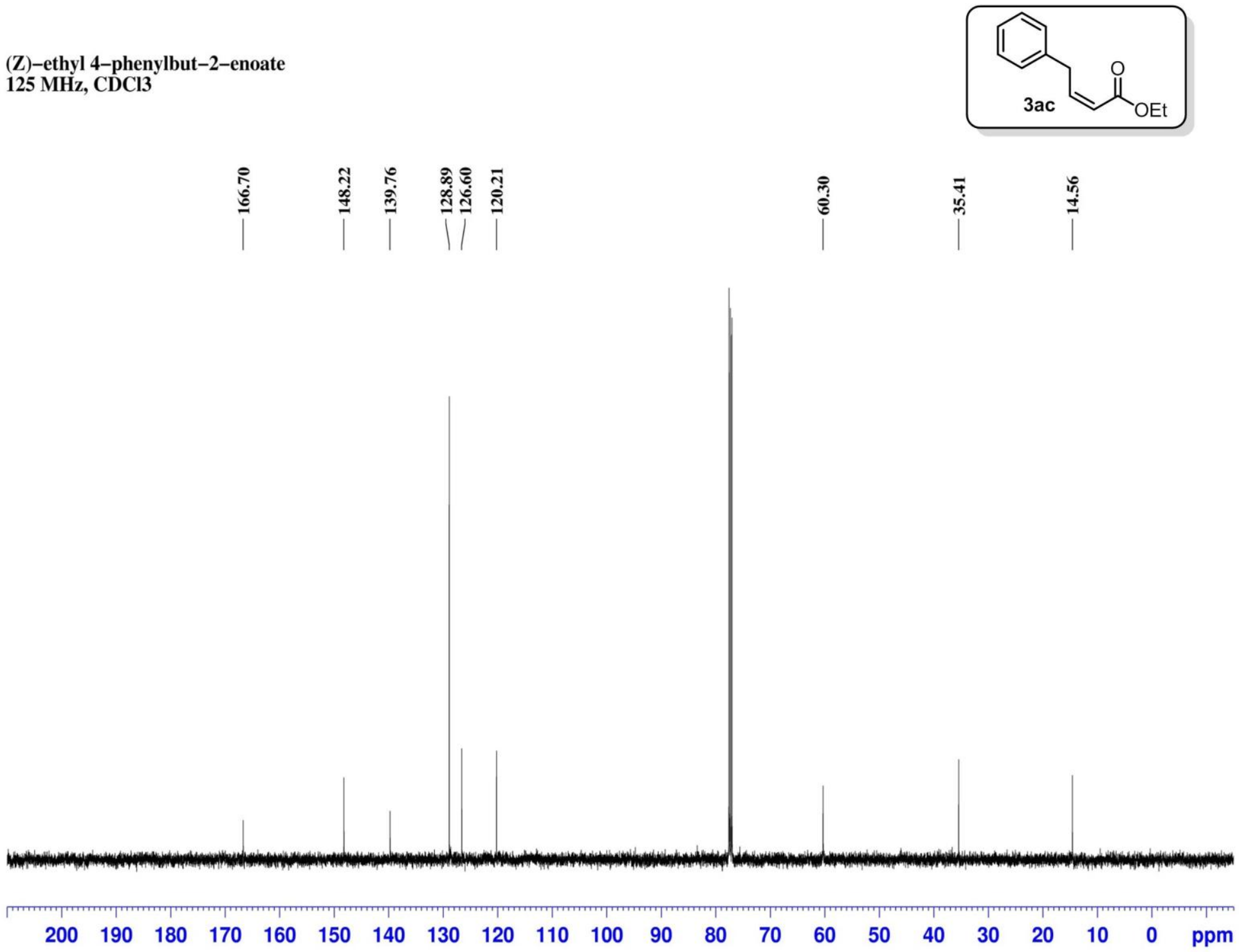
(Z)-ethyl 5-(cyclohex-3-en-1-yl)pent-2-enoate $125 \mathrm{MHz}, \mathrm{CDCl} 3$
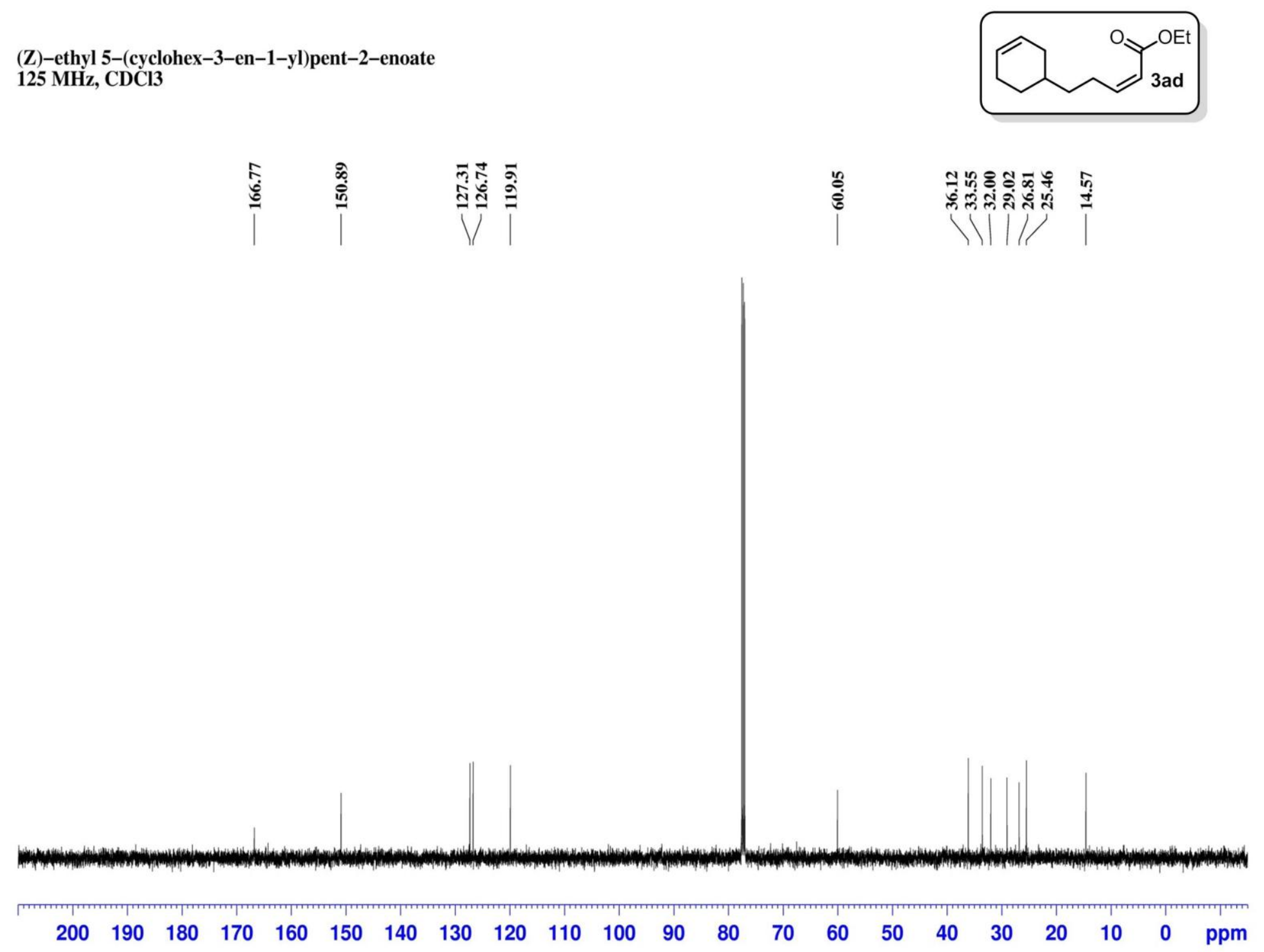
(Z)-ethyl 6-acetamidohex-2-enoate

$125 \mathrm{MHz}, \mathrm{CDCl} 3$
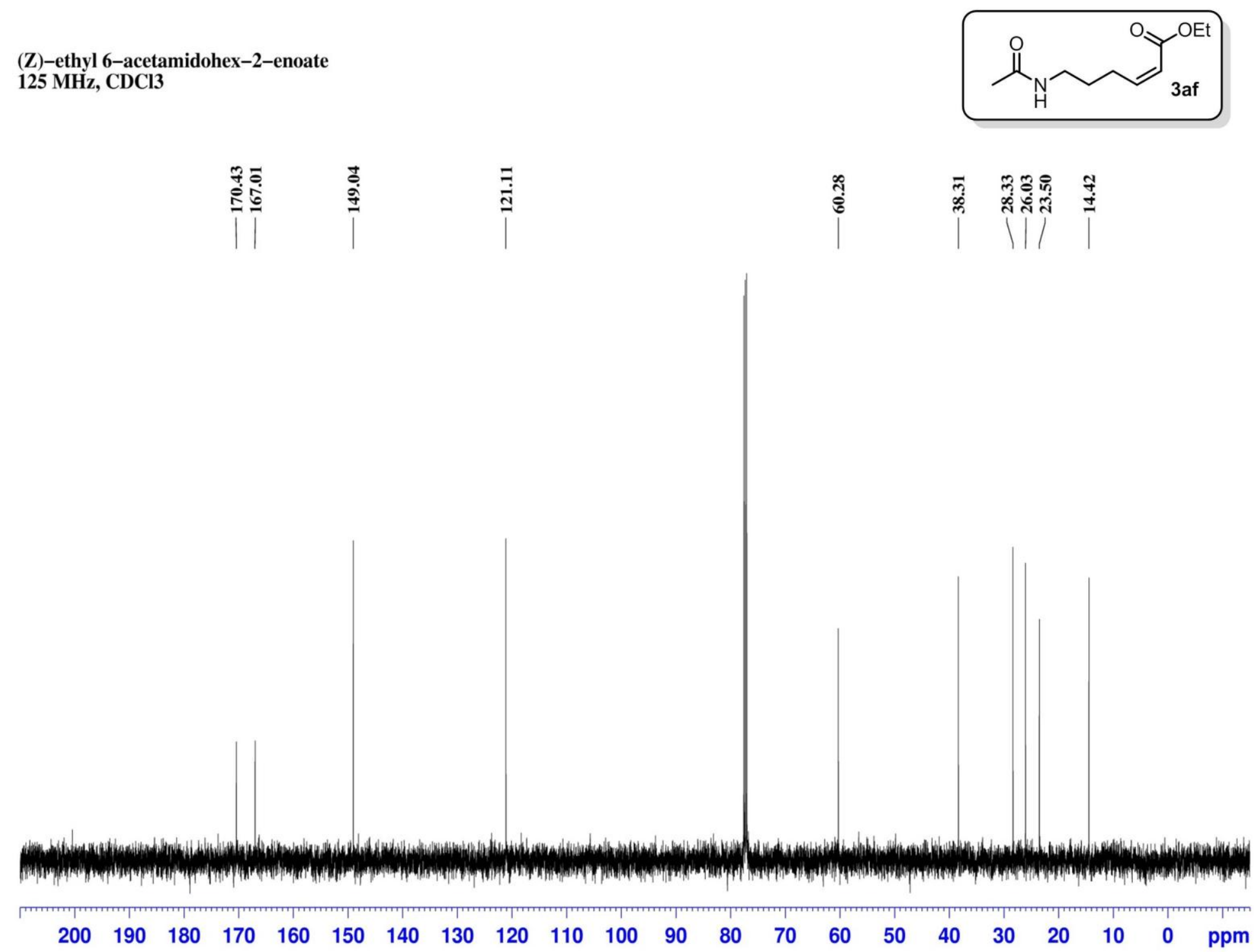
(2-cyclohexylideneethyl)benzene $125 \mathrm{MHz}, \mathrm{CDCl} 3$
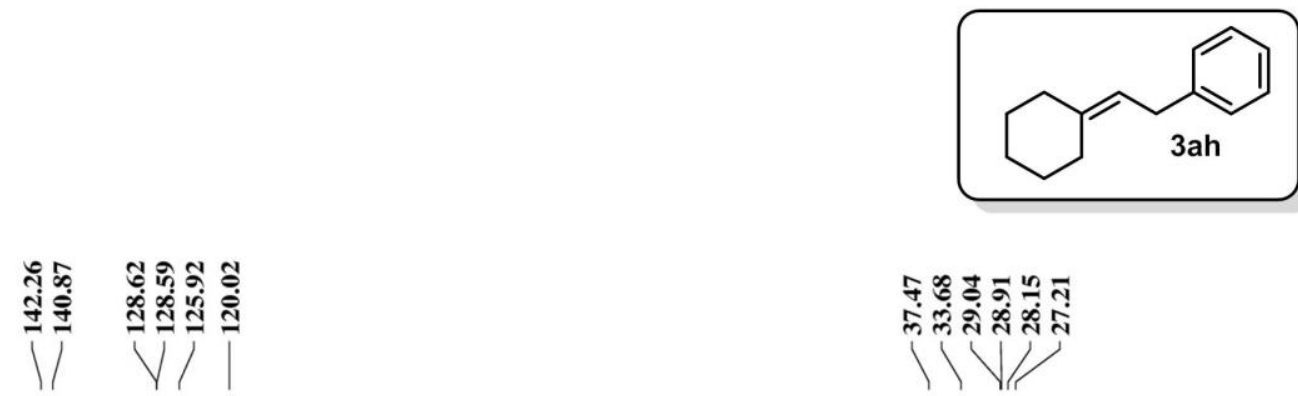

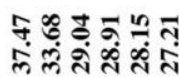

$1 \mathrm{VI}$

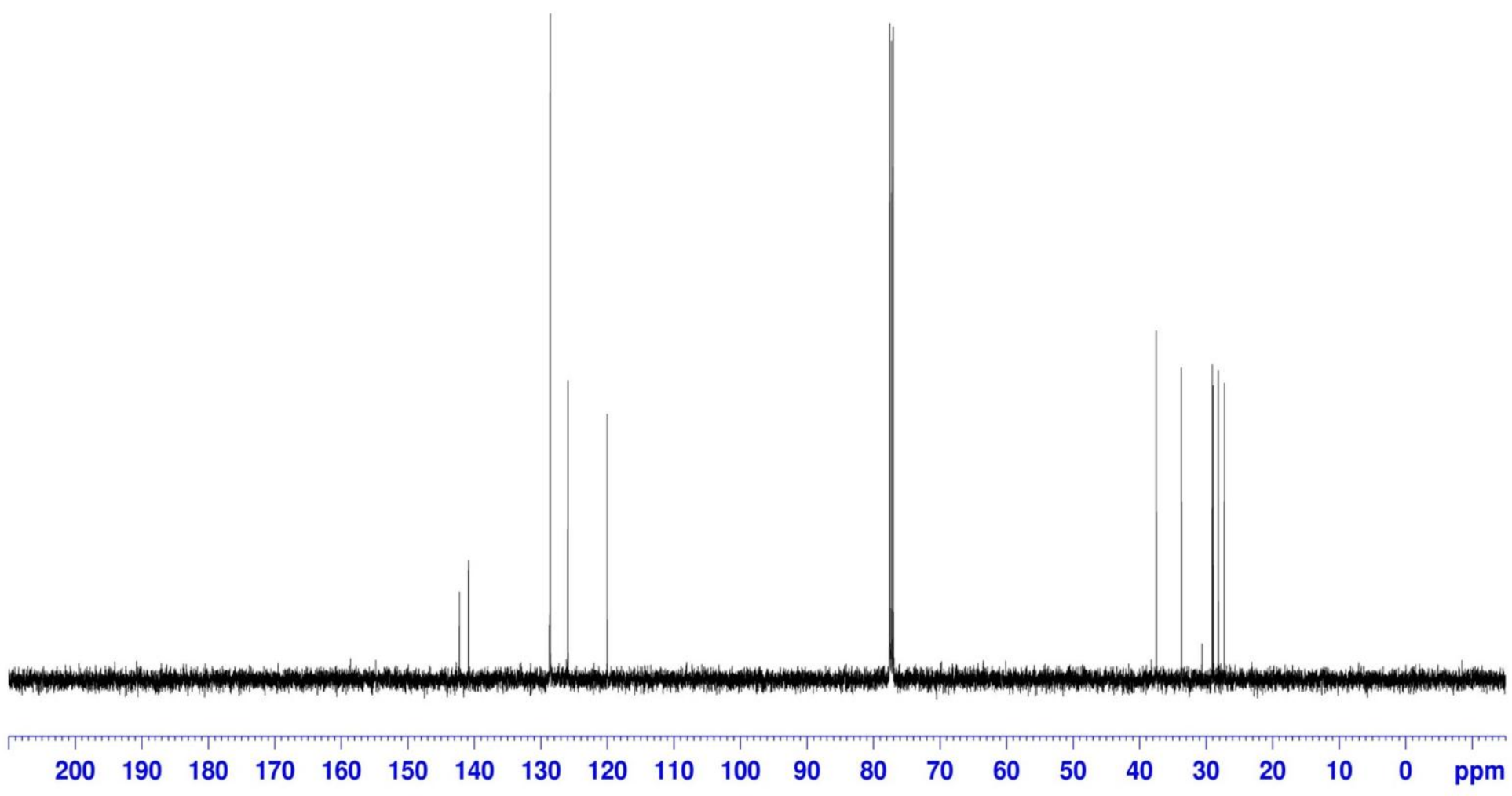


4-(3-cyclohexylidenepropyl)cyclohex-1-ene $125 \mathrm{MHz}, \mathrm{CDCl} 3$

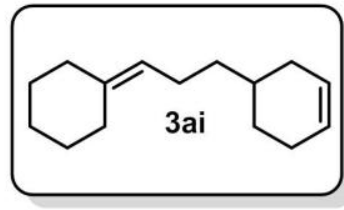

$$
\text { | }
$$

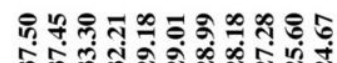

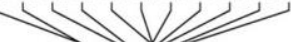

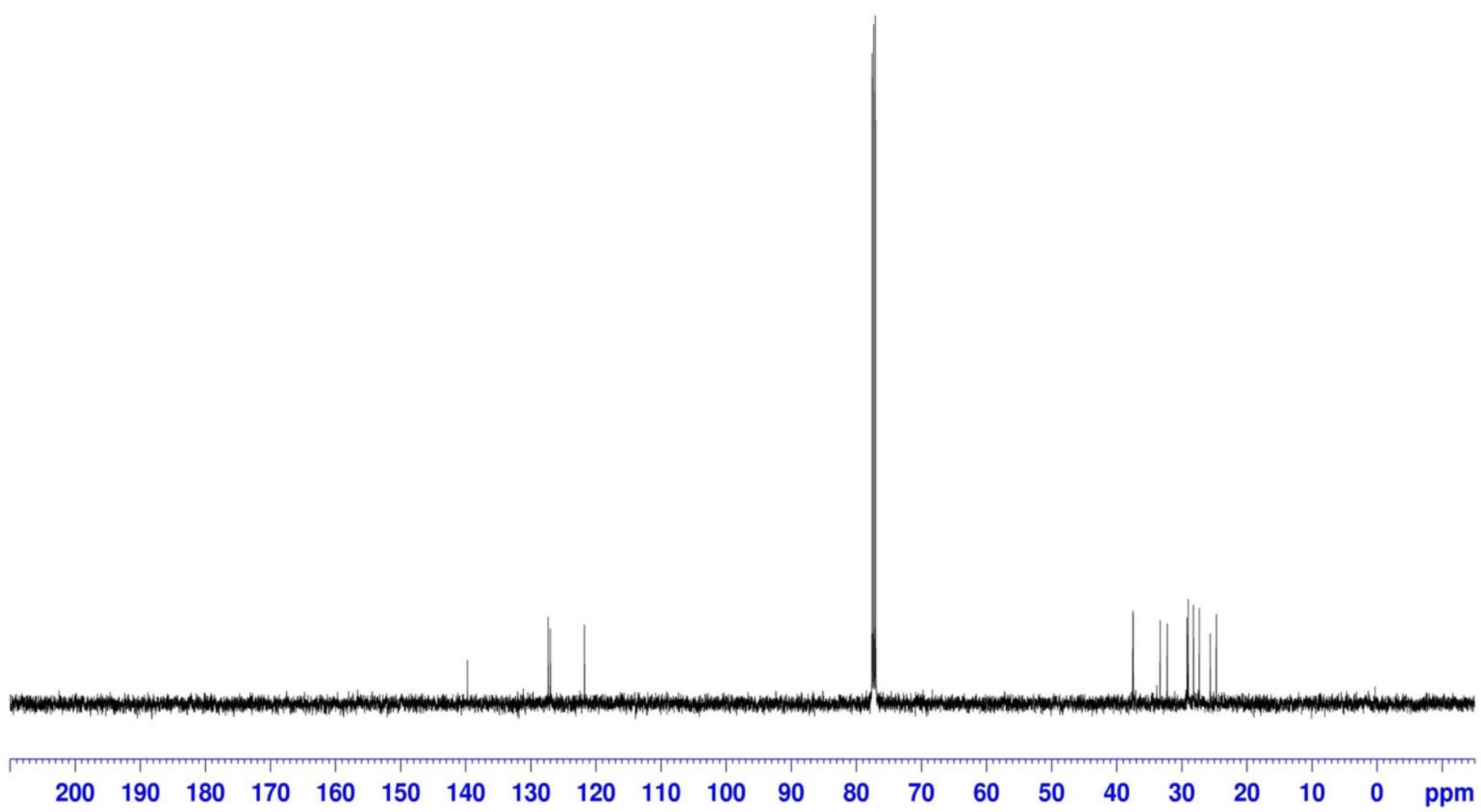


2-(cyclohexylidenemethyl)bicyclo[2.2.1] heptane $125 \mathrm{MHz}, \mathrm{CDCl} 3$

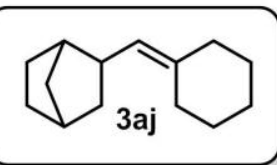

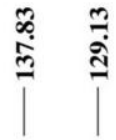

कํำํํำ

N V

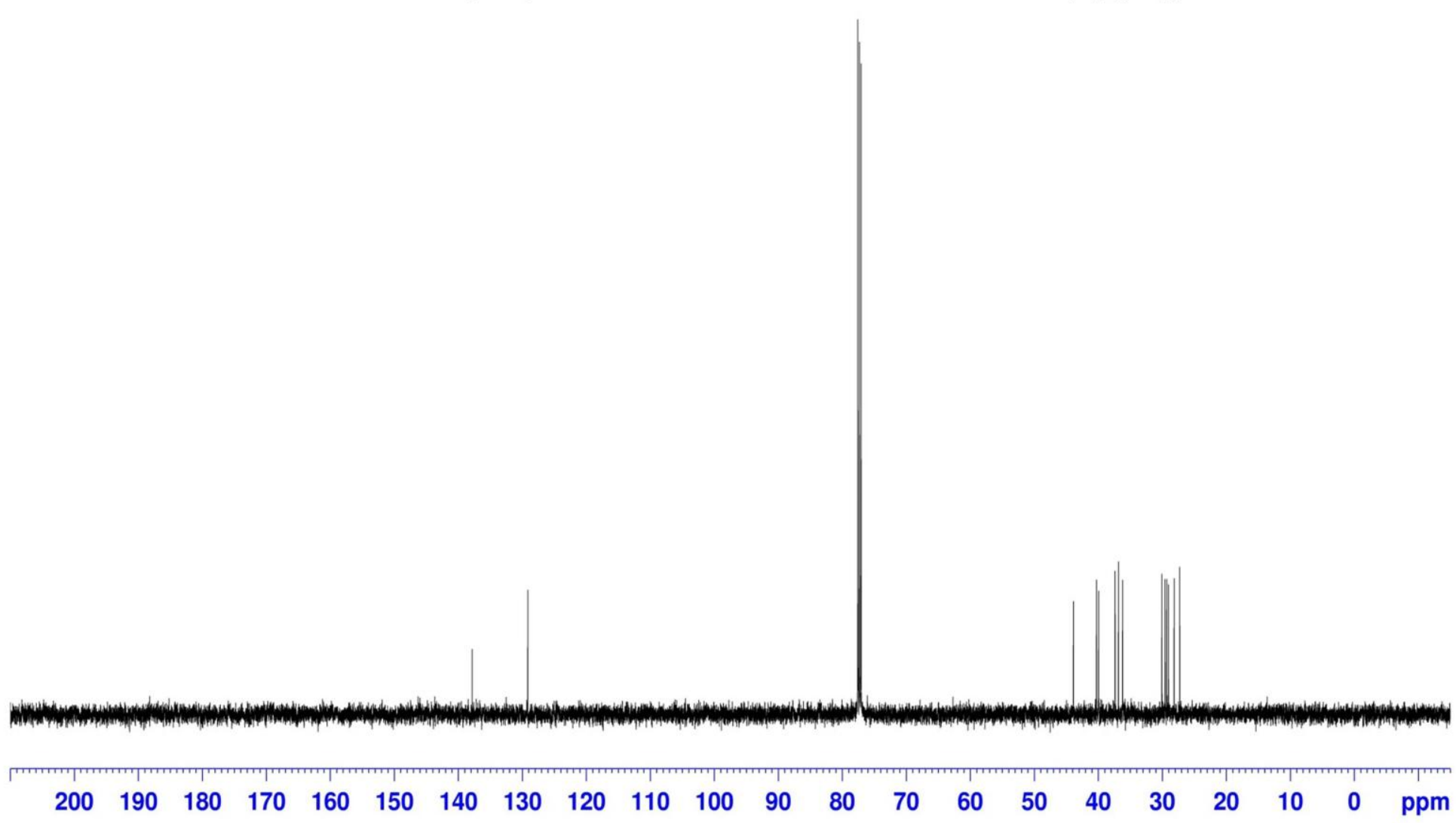


N-(4-cyclohexylidenebutyl)acetamide $125 \mathrm{MHz}, \mathrm{CDCl} 3$

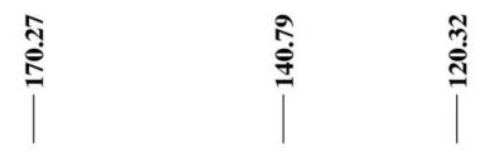

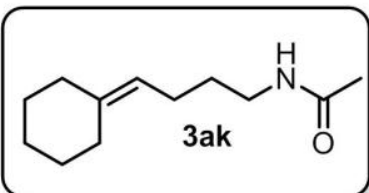

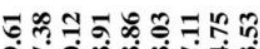

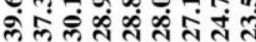

1 W/ll

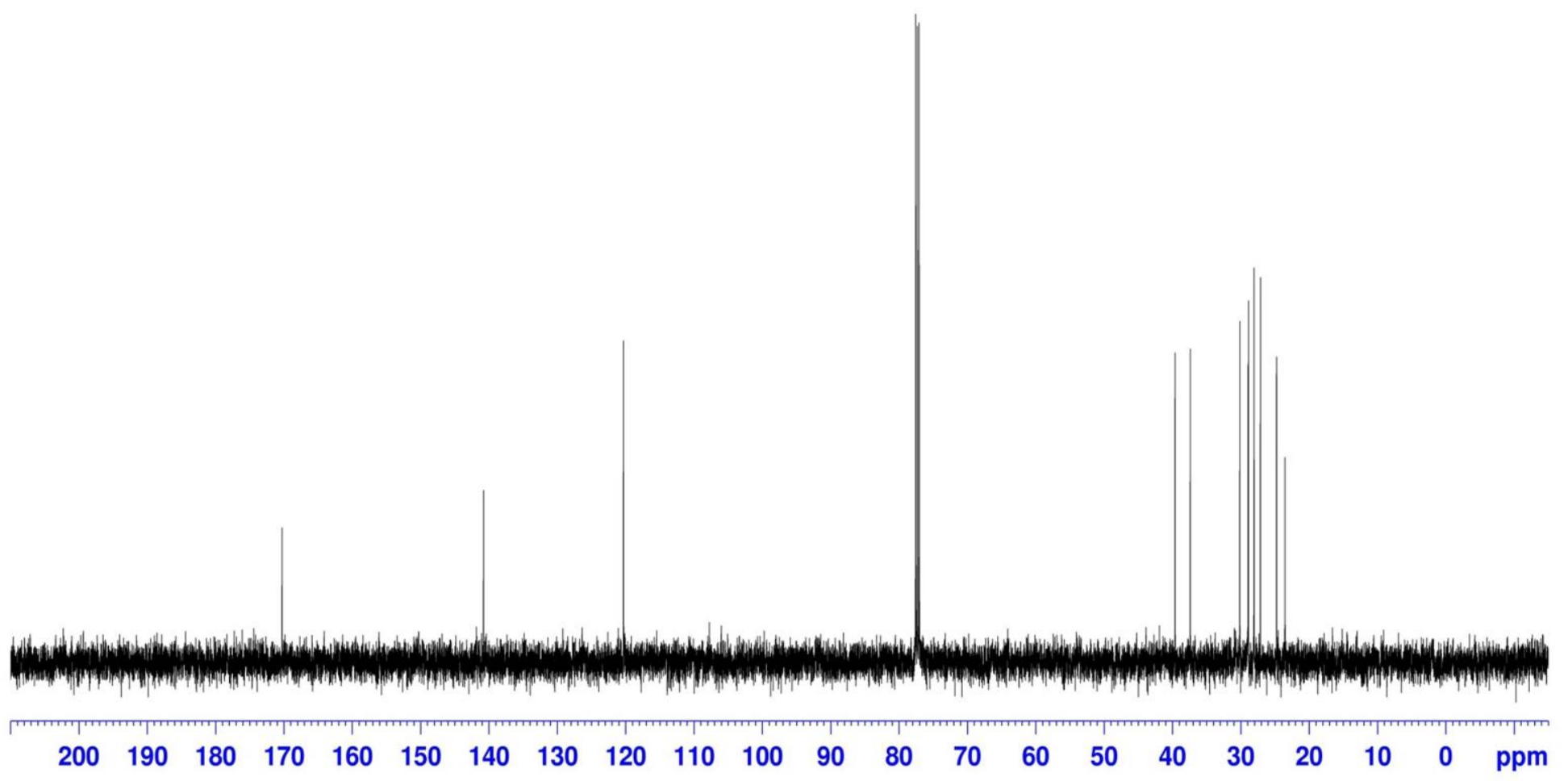


3-(cyclopent-1-en-1-yl)propyl acetate $125 \mathrm{MHz}, \mathrm{CDCl} 3$
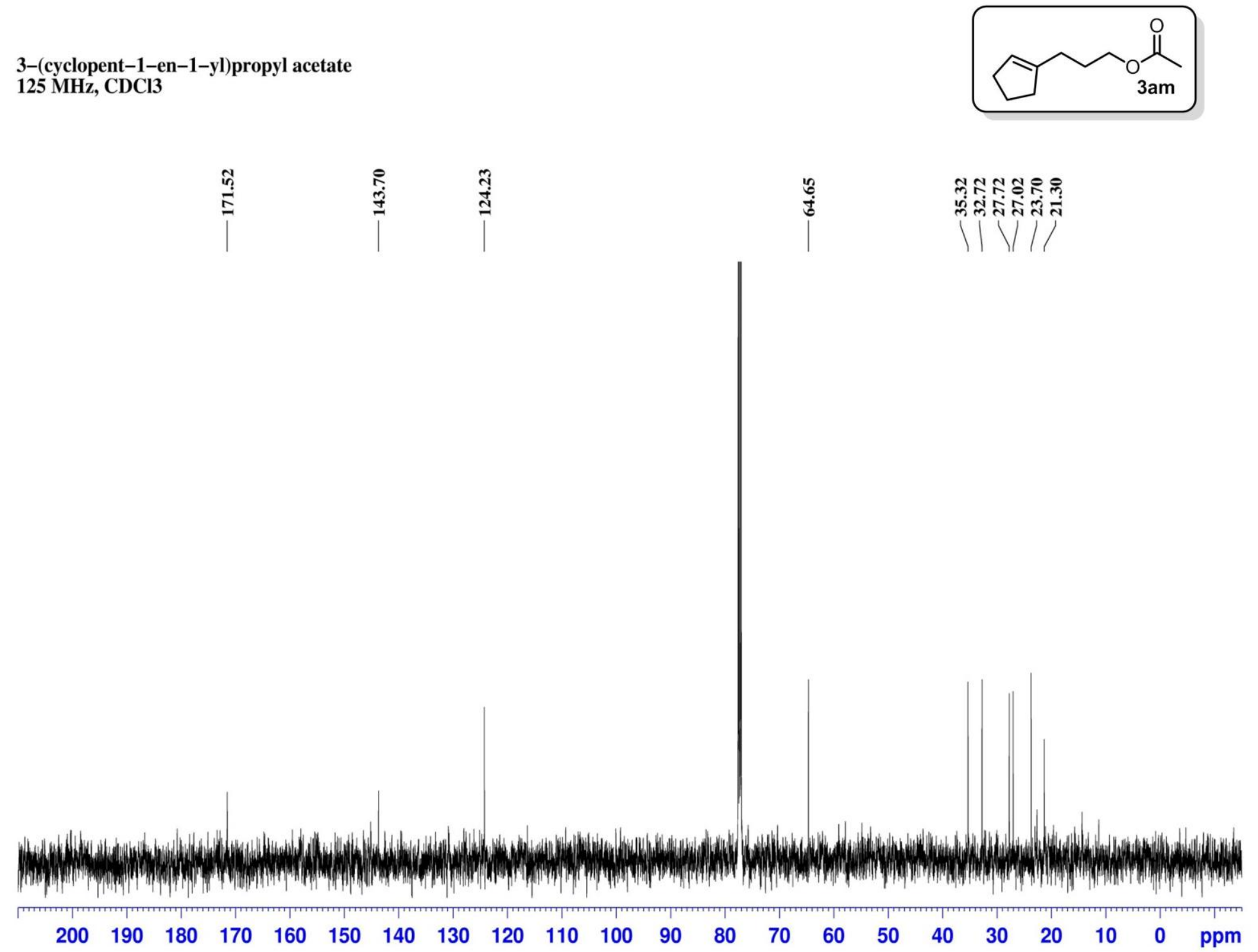
(E)-1-methoxy-4-(5-methoxypent-1-en-1-yl)benzene $125 \mathrm{MHz}, \mathrm{CDCl} 3$
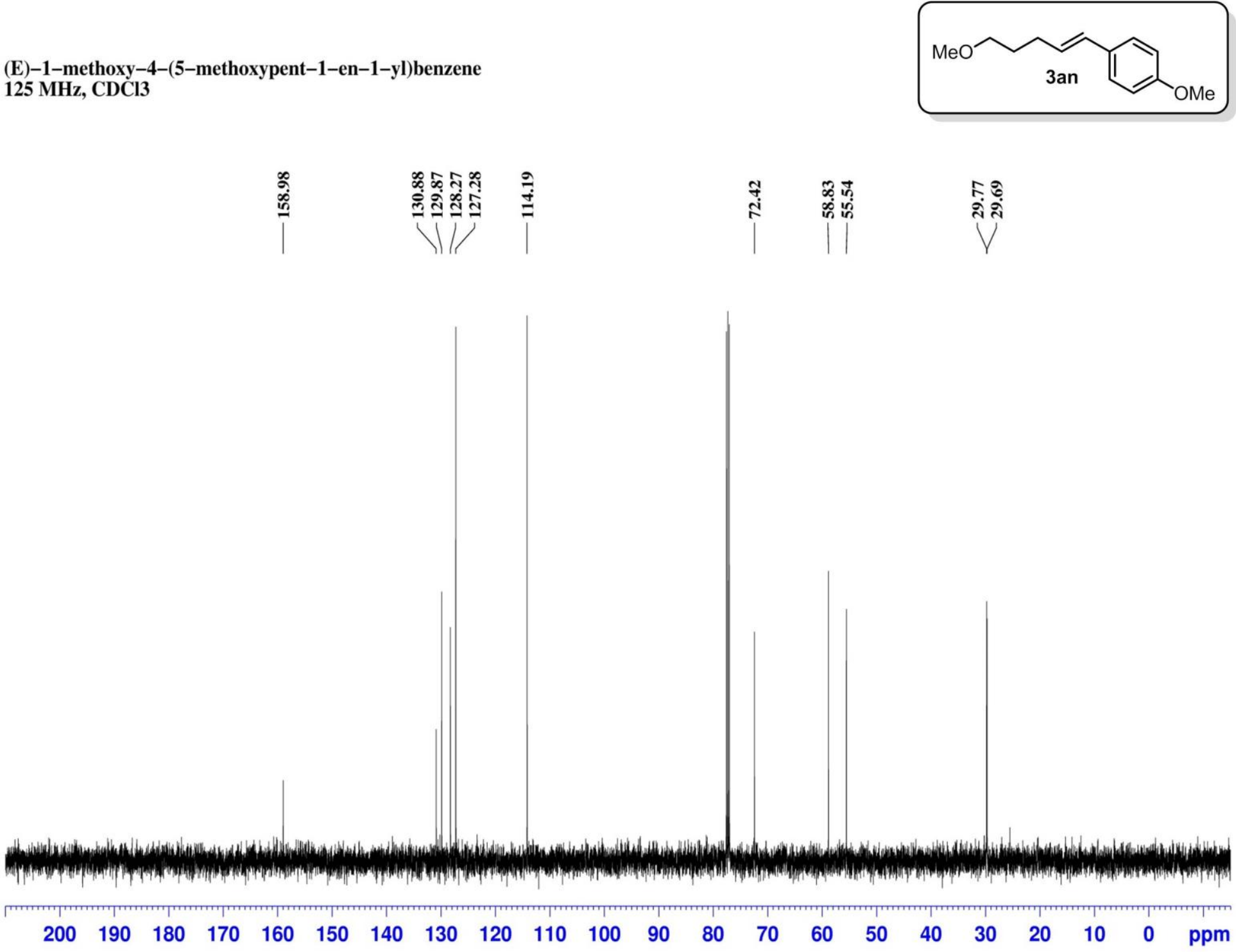